\title{
Health literacy : a neglected European public health disparity
}

Citation for published version (APA):

Sorensen, K. (2013). Health literacy : a neglected European public health disparity. [Doctoral Thesis, Maastricht University]. Universitaire Pers Maastricht. https://doi.org/10.26481/dis.20131106ks

Document status and date:

Published: 01/01/2013

DOI:

$10.26481 / \mathrm{dis} .20131106 \mathrm{ks}$

Document Version:

Publisher's PDF, also known as Version of record

\section{Please check the document version of this publication:}

- A submitted manuscript is the version of the article upon submission and before peer-review. There can be important differences between the submitted version and the official published version of record.

People interested in the research are advised to contact the author for the final version of the publication, or visit the DOI to the publisher's website.

- The final author version and the galley proof are versions of the publication after peer review.

- The final published version features the final layout of the paper including the volume, issue and page numbers.

Link to publication

\footnotetext{
General rights rights.

- You may freely distribute the URL identifying the publication in the public portal. please follow below link for the End User Agreement:

www.umlib.nl/taverne-license

Take down policy

If you believe that this document breaches copyright please contact us at:

repository@maastrichtuniversity.nl

providing details and we will investigate your claim.
}

Copyright and moral rights for the publications made accessible in the public portal are retained by the authors and/or other copyright owners and it is a condition of accessing publications that users recognise and abide by the legal requirements associated with these

- Users may download and print one copy of any publication from the public portal for the purpose of private study or research.

- You may not further distribute the material or use it for any profit-making activity or commercial gain

If the publication is distributed under the terms of Article $25 \mathrm{fa}$ of the Dutch Copyright Act, indicated by the "Taverne" license above, 


\section{Health literacy: \\ a neglected European \\ public health disparity}

Kristine Sørensen 


\section{Colophon}

The research for this dissertation was performed at the department of International Health within the School for Public Health and Primary Care (CAPHRI), Faculty of Health, Medicine, and Life Sciences, Maastricht University, which participates in the Netherlands School for Primary Care Research (CaRe) and acknowledged by the Royal Dutch Academy of Science (KNAW). Financial support for the European Health Literacy project (HLS-EU) was provided through the grant agreement 2007-113 of the European Commission. The study on Citizen's consultations on health was commissioned and financed by the Council of Europe. Dissertation: Health literacy: a neglected European public health disparity.

Author: Kristine Sørensen

Cover design: Zjelco Felder

ISBN: 9789461592637

(c) Copyright: K. Sørensen, Maastricht, the Netherlands, 2013. All rights reserved. No part of this publication may be reproduced without permission of the copyright owner. 


\section{Health literacy: \\ a neglected European \\ public health disparity}

Dissertation

to obtain the degree of Doctor at Maastricht University, on the authority of the Rector Magnificus Prof. dr. L. L. G. Soete, in accordance with the decision of the Board of Deans, to be defended in public on Wednesday 6 November 2013, at 16.00 hours

by

Kristine Sørensen

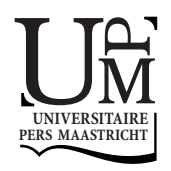




\section{Supervisors}

Prof. dr. H. Brand

Prof. dr. S. van den Broucke, Université Catholique de Louvain, Belgium

\section{Co-supervisor}

Dr. P. Schröder-Bäck

\section{Assessment Committee}

Prof. dr. N. de Vries

Prof. dr. I. Kickbusch, Geneva Graduate Institute, Switzerland

Dr. D. Levin-Zamir, Haifa University and Clalit, Israel

Dr. D. Townend

Prof. dr. T. van der Weijden 
The research presented in the dissertation is partly made in collaboration with

The Consortium of the European Health Literacy Project (HLS-EU), 2009-2012

$\begin{array}{ll}\text { Austria } & \text { Jürgen M Pelikan, Florian Röthlin, Kristin Ganahl, } \\ & \text { Ludwig Boltzmann Institute Health Promotion, Vienna } \\ \text { Bulgaria } & \text { Kancho Tchamov, Alexander Zhekov, } \\ & \text { Medical Faculty, Sofia } \\ \text { Monika Mensing, Gudula Ward } & \text { NRW National Health Centre, Bielefeld } \\ \text { Germany } & \text { Demosthenes Agrafiotis, Elizabeth Eionnides, Barbara } \\ \text { Greece } & \text { Kondilis } \\ & \text { National School of PuHealth, Athens } \\ & \text { Gerardine Doyle, James Fullam, Kenneth Cafferkey, } \\ \text { Ireland } & \text { University College Dublin } \\ \text { The Netherlands } & \text { Helmut Brand, Kristine Sørensen } \\ & \text { Maastricht University (project leader) } \\ & \text { Marïel Droomers, Jantine Schuijters, Ellen Uiters, Iris van } \\ & \text { der Heide } \\ \text { Dutch Institute for Health and Environment (RIVM) } \\ \text { Zofia Slonska } \\ \text { The Cardinal Wyszyński Institute of Cardiology, Warsaw } \\ \text { Poland }\end{array}$

The Steering Group of the Joint Venture on Health Literacy of CSR Europe: Introducing a Blueprint of Business Actions on Health Literacy, 2010-1013

CSR Europe

BITC

Edenred

Maastricht University

Microsoft

MSD Europe

Nestlé
Christine Neumann

Tanya Kennedy

Nolween Bertrand, Charlotte Malvy

Helmut Brand, Kristine Sørensen (academic partner)

Ray Pinto, Elena Bonfiglioli

Alexander Rödiger

Cécile Duprez Naudy, Stephane Cosandey

Study on Citizen Consultations on the protection of health commissioned by Council of Europe, 2012

Council of Europe

Maastricht University
Mohruba Garfazada, Thorsten Afflerbach

Christoph Aluttis, Kristine Sørensen, Helmut Brand 



\section{Contents}

$\begin{array}{lll}\text { Chapter } 1 & \text { Introduction }\end{array}$

Part 1 Defining health literacy 23

Chapter 2 Health literacy - a review of definitions and models 25

Chapter 3 The European Health Literacy Glossary 49

Part $2 \quad$ Measuring health literacy 65

Chapter 4 Measuring health literacy in populations: HLS-EU-Q 67

Chapter 5 The European Health Literacy Survey (HLS-EU) 89

$\begin{array}{lll}\text { Part } 3 & \text { Advancing health literacy in Europe } & 103\end{array}$

Health literate systems

Chapter 6 The movers and shakers of health literacy: a Danish case-study 105

$\begin{array}{lll}\text { Chapter } 7 & \text { Health literacy - a catalyst for knowledge transfer } & 119\end{array}$

Health literate businesses

Chapter $8 \quad$ Health literacy - a strategic asset for corporate social responsi- 131 bility

Chapter 9 Developing health literate businesses as part of corporate social 141 responsibility

$\begin{array}{lll}\text { Chapter } 10 & \text { Blueprint of business actions on health literacy } & 159\end{array}$ Health literate societies

$\begin{array}{lll}\text { Chapter } 11 & \text { Health literacy, social justice and ethics } & 171\end{array}$

Chapter 12 Health literacy and citizen consultations: shaping health literate 181 societies

$\begin{array}{ll}\text { Chapter } 13 \text { General discussion } & 199\end{array}$

Bibliography $\quad 211$

Figures, tables and abbreviations $\quad 227$

Co-authors 233

Summary - Samenvatting - Resumé $\quad 237$

Dankwoord - Acknowledgements - Tak 249

Curriculum Vitae $\quad 255$ 
Living a long and healthy life

Health literacy matters.

HLS-EU the Movie 


\section{CHAPTER 1}

Introduction

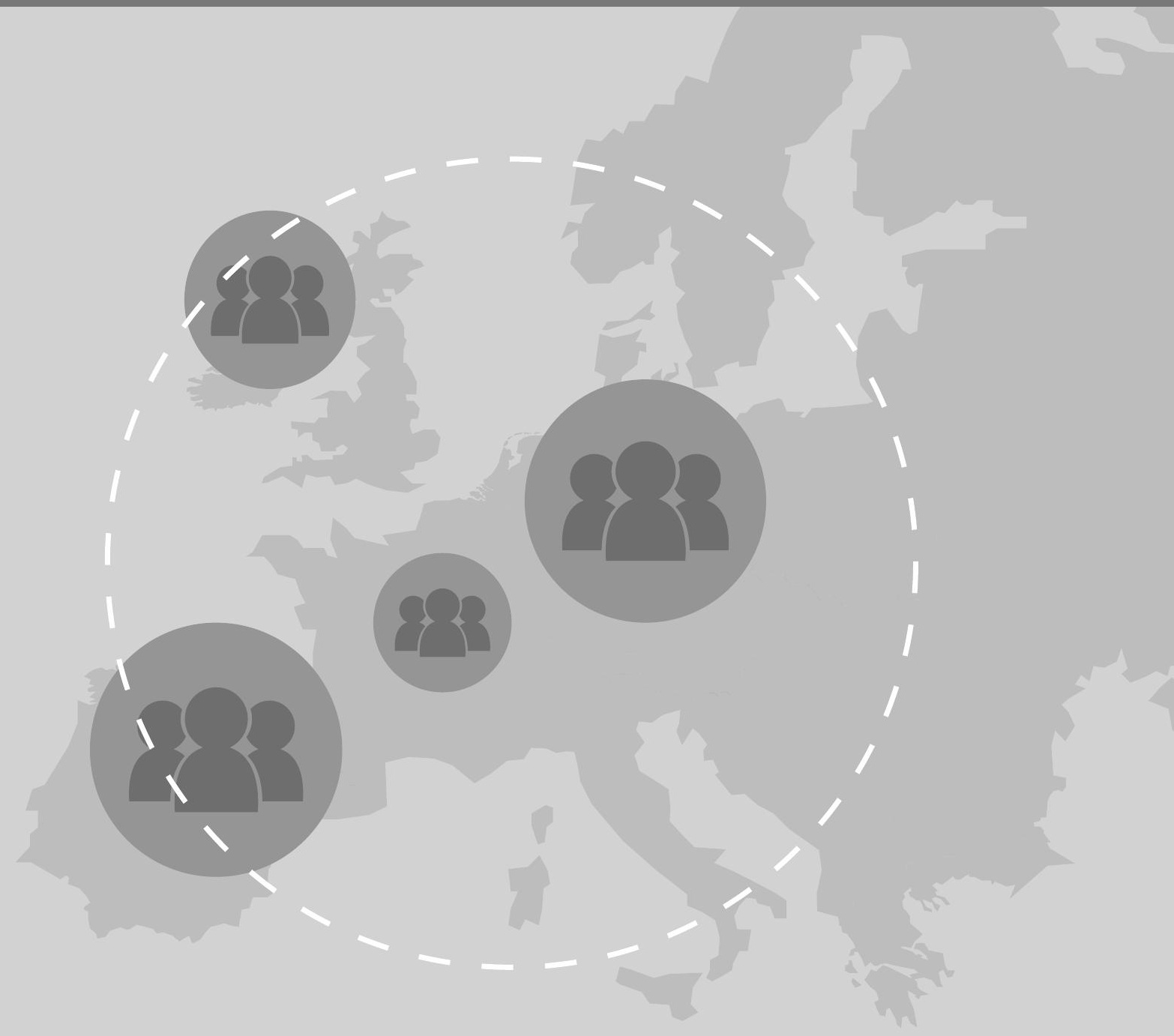




\section{Introduction}

$\mathrm{H}$ ealth literacy is closely linked to literacy and entails the knowledge, motivation and competency to access, understand, appraise and apply information to form judgment and make decisions concerning healthcare, disease prevention, and health promotion to promote and maintain quality of life during the life course (Sorensen, Van den Broucke, et al., 2012). Health literacy is critical to empowerment and to active and informed participation in health and healthcare (Coulter \& Ellins, 2006; Kickbusch \& Maag, 2008). Yet, until a few years ago European evidence on health literacy was lacking concerning the status of health literacy in Europe; which made it difficult to compare the prevalence of low health literacy with other countries (HLS-EU Consortium, 2008) and the concept as a European research topic had only been scarcely explored (Kondilis, Soteriades, \& Falagas, 2006). Besides, concerns were raised whether health literacy was not merely old wine in new bottles; as it was by some considered a repackaging of health promotion (Tones, 2002a). However, the situation has changed. In recent years, a number of publications, many of which were related to the European Health Literacy project (HLS-EU), have spurred the attention for health literacy and the evidence base is steadily increasing (HLS-EU Consortium, 2012a). With the HLS-EU project as reference point, this dissertation explores how the health literacy has been defined, measured and applied in Europe to demonstrate how health literacy can be advanced further in the future.

From margins to mainstream - reaching a tipping point for European health literacy Health literacy matters! This is the core message of the video clip "HLS-EU The Movie" that can be watched at YouTube and was launched at the European Health Forum Gastein in October 2012 by the HLS-EU Consortium (Sorensen, Felder, \& Media\&More, 2013, 2012). The HLS-EU Consortium conducted the European Health Literacy project (HLS-EU), which took place from 2009 to 2012 under the leadership of Maastricht University and involved eight associated research partners from Austria, Bulgaria, Germany, Greece, Ireland, the Netherlands, Poland and Spain. The HLS-EU project aimed to bring health literacy to the forefront of public health in Europe through measuring health literacy in Europe; establishing a European network for professionals and decision-makers engaged in health literacy and creating national advisory groups to disseminate health literacy survey results and stimulate the integration of health literacy into policy agendas (HLS-EU Consortium, 2008). HLS-EU the Movie mainstreams complex European health literacy research results and raises the awareness of health literacy implications and assets in policy and practice.

Being accessible as part of mainstream on YouTube is one thing; being recognized for its importance by distinguished policy stakeholders in the field of health is another. 
Yet, this is what the HLS-EU project has achieved. The fact that health literacy matters in European health policy was highlighted and emphasized with the dedication of the European Health Award 2012 to the HLS-EU Consortium by the European Health Forum Gastein "in recognition of an outstanding contribution in meeting European health challenges by implementing a health policy initiative of European importance" (European Health Forum Gastein, 2012a). However, the work of the HLS-EU Consortium is not only a success story on its own. It forms part of a wider development and mobilization, which entails an increasing attention to health literacy in Europe as part of healthcare; disease prevention; health protection and promotion. In the last decade the scientific publications on health literacy have increased dramatically (Kondilis, Kiriaze, Athanasoulia, \& Falagas, 2008; Sorensen, Nørgaard, \& Maindal, 2013) as illustrated in Figure 1.1.

Although health literacy emerged as a concept for the first time in the 1970s as part of the educational field in the United States (Simonds, 1974), it developed independently in Europe in the 1990s, where staff at the World Health Organisation's European Office included the term in the Health Promotion Glossary (Nutbeam, 1998) without being aware of the developments in North America (Nutbeam, 2012). In spite of the introduction in the 1990s, it took several years before it received significant attention. This required advocacy at, amongst others, the European Health Forum Gastein (European Health Forum Gastein, 2010, 2012b; Kickbusch, Wait, \& Maag, 2005) and the European Patients Forum, who has been a key player in the 00s in creating awareness concerning the importance of health literacy (European Patients' Forum, 2008). Whereas a decade ago references were made to single individuals playing an active role to promote health literacy in Europe, five years later clusters and collaborative learning networks scattered throughout Europe had been established. Today, "Health Literacy Europe" is a Europe-wide network for professionals, national networks and advisory boards as well as established research groups in many countries in Europe (Sorensen, 2012).

Meanwhile, milestones in the development of health literacy can also be identified at the policy level (Figure 1.2). They include the integration of health literacy in the European Commission's White Paper: Together for Health (European Commission, 2007), and in the strategic document "Health 2020" of the World Health Organisation's European Office (World Health Organisation's European Office, 2012). The influence is reflected at national levels, too, where initial policy actions deserves attention such as the Welsh integration of health literacy into a national strategy on preventing inequalities in health (Puntoni, 2012; Welsh Assembly Government, 2011) and the inclusion of the advancement of health literacy as one of ten national health goals in Austria (delle Grazie, 2012). The European Health Conference in Brussels 2011 (HLS-EU Consortium, 2012b) received high-level attention by hosting the then acting European Commission- 
er for Health and Consumers, Mr. John Dalli, as a keynote speaker. He highlighted that "the results of this survey provide a sound evidence base to guide national, regional and European approaches to improve health literacy in the coming years" (Dalli, 2011).

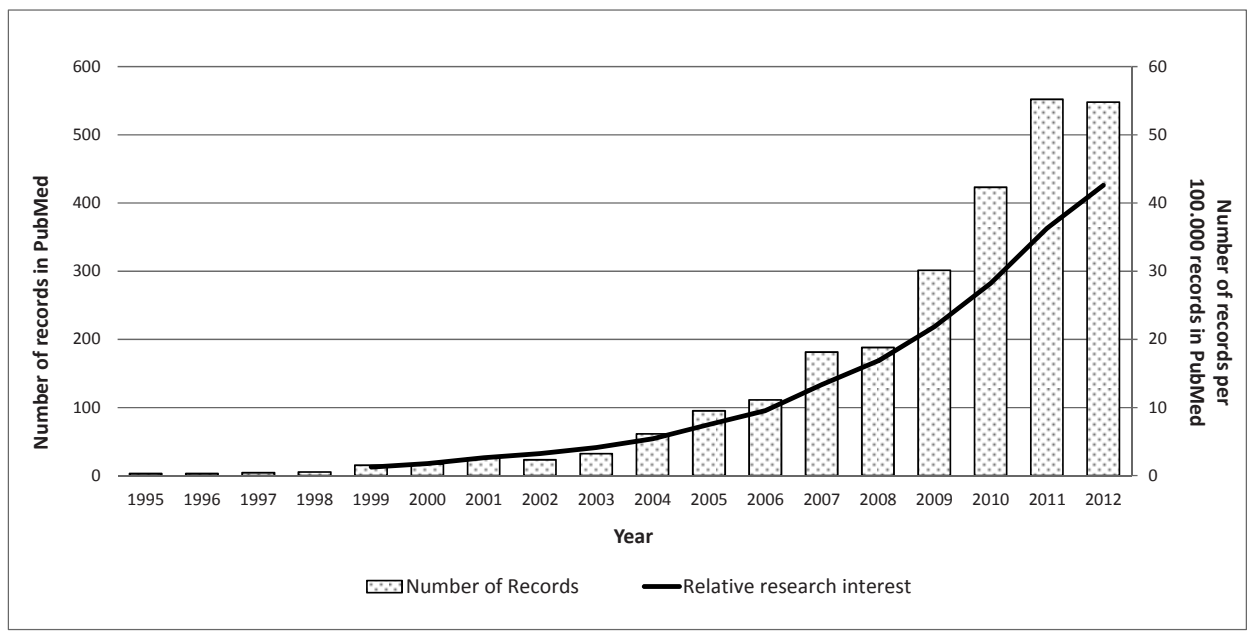

Figure 1.1 Results of a search in PubMed concerning 'health literacy' for the period of 1995-2012. The relative research interest is illustrated by the trend line based on the average interest in the past five years (Sorensen, Nørgaard, et al., 2013)

Nevertheless, health literacy still remains a neglected public health issue and barriers still remain to actively face and overcome the disparity linked to limited health literacy. The current lack of attention from decision-makers, the challenges concerning the translation of the notion and hence the understanding of its meaning by non-native speakers and the lack of human and financial resources at national levels hinder the facilitation of health literacy efforts on a wider scale (Borg \& Sorensen, 2012). Yet, it seems clear that at European level the HLS-EU project has created a second wave of attention for the concept, which grows exponentially, following the first wave initiated by single individuals in the beginning of the last decade. It is envisaged that this second wave brings along new research partnerships, new policy developments and new health literacy initiatives which will help to improve the quality of life for citizens across Europe. Health literacy in Europe may be still in its infancy, but a tipping point has been reached and the critical number of stakeholders seems strong enough to multiply the efforts in the future.

\section{Global perspectives}

Health literacy is also an emerging political topic on the global health agenda. The Nairobi Call to Action launched in 2009 by the World Health Organisation emphasized health literacy in relation to empowerment, stating that there is a need to support 
empowerment by designing health literacy interventions based on community needs and priorities in their political, social and cultural context and by ensuring that communities are able to access and act on knowledge and overcome any barriers to health (World Health Organisation, 2009). In addition, the Organisation for Economic Cooperation and Development (OECD) has emphasized the need to link health literacy to the discussion of healthy ageing (Oxley, 2009).

These and other developments in global health literacy research have been mapped in a recent study by Andrew Pleasant (Pleasant, 2012). According to the study, the United States of America holds a pole position in terms of research, policy initiatives and interventions regarding health literacy. The rest of the countries in the world are only slowly joining these efforts. As it is a new area of interest for many stakeholders, leadership needs to be established, not only in research, but especially with regard to political decision-making on advancing health literacy at societal level. Interestingly, Pleasant highlights as a clear result of the data collection and reporting of health literacy that "when governments have collected data on the status of health literacy among the populations they serve, they have also created health literacy policies and intervention projects. This project's design is limited in its ability to determine whether the data collection prompts policy development, or whether policy development causes data collection efforts, but a relationship clearly exists" (Pleasant, 2012).

In Europe policies to enhance health literacy were developed despite the lack of data. For instance, health literacy was included in the White Paper Together for Health in 2006 (European Commission, 2007) before European data on health literacy were available. However, five years later, when the initial results of the European Health Literacy Survey were made available (HLS-EU Consortium, 2012b), this provoked additional attention and political action in several countries. For example, in Austria health literacy was marked as one of ten national goals in 2012 (delle Grazie, 2012). Although North America may still be in the pole position, research partnerships have now been established across continents to increase the international evidence base on health literacy (Protheroe, Wallace, Rowlands, \& DeVoe, 2009). Thus, it is envisaged that the global devotion to health literacy will be growing in the years to come. 


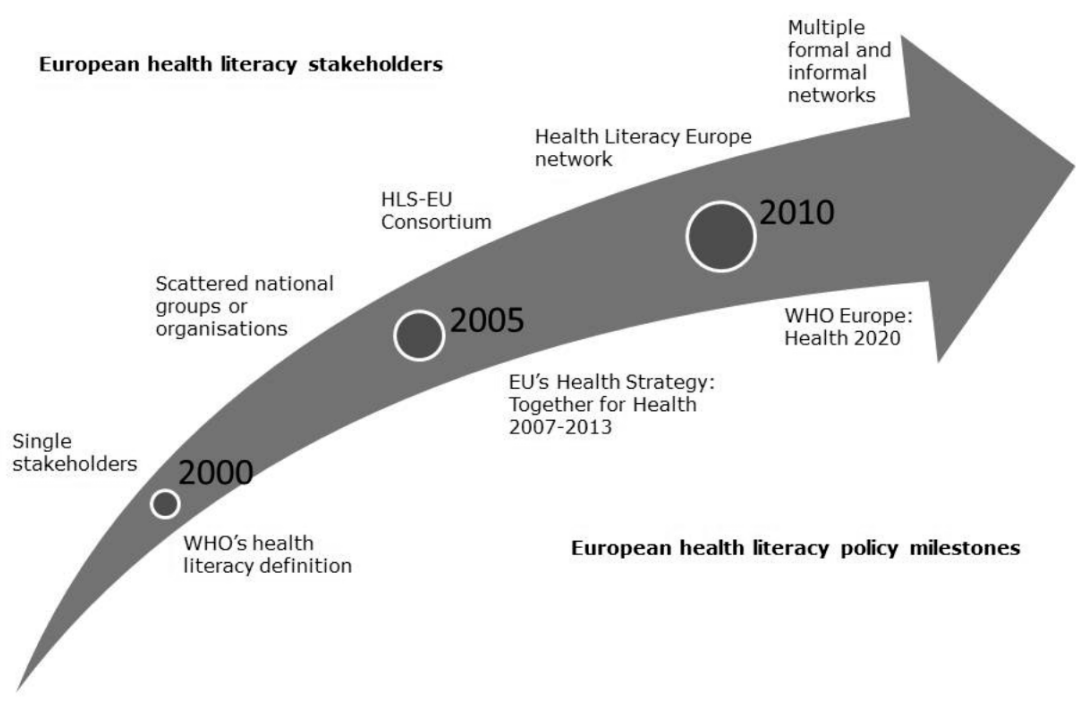

Figure 1.2: European health literacy stakeholders and policy milestones (Sorensen, 2012)

Defining, measuring and advancing health literacy in Europe: the research questions The starting point for the PhD project was the lack of evidence on the status of health literacy in Europe; the initial research questions were closely linked to research obligations outlined in the HLS-EU project. However, during the execution of the project, ideas for spin-off research emerged. Research questions concerning the stakeholders of health literacy, the role of corporate social responsibility, and citizen consultations and knowledge transfer with regard to public health genomics were developed along with an interest on the ethical arguments related to health literacy. Eventually, these questions were the basis for the design of sub-studies focusing on eleven subquestions for the doctoral project, as outlined in Figure 1.3. In addition, during the research process I was continuously inspired by the wise words of Rudyard Kipling (Kipling, 1902):

I keep six honest serving-men

(They taught me all I knew);

Their names are What and Why and When

And How and Where and Whom.

The current dissertation provides a combination of quantitative and qualitative research. The key differences between qualitative and quantitative research approaches are summarized in Table 1.1 (Hennink, Hutter, \& Bailey, 2011). 
Table 1.1: Key differences between qualitative and quantitative research (Hennink et al., 2011)

\begin{tabular}{lll}
\hline & Qualitative research & Quantitative research \\
\hline Objective & $\begin{array}{l}\text { To gain a detailed understanding of } \\
\text { underlying reasons, beliefs, motiva- } \\
\text { tions }\end{array}$ & $\begin{array}{l}\text { To quantify data and extrapolate } \\
\text { results to a broader population }\end{array}$ \\
\hline Purpose & $\begin{array}{l}\text { To understand why? How? What is } \\
\text { the process? What are the influences } \\
\text { or contexts? }\end{array}$ & $\begin{array}{l}\text { To measure, count, quantify a prob- } \\
\text { lem. How much? How often? What } \\
\text { proportion? Relationships in data. }\end{array}$ \\
\hline Data & Data are words (called textual data) & Data are numbers or numerical data \\
\hline Study population & $\begin{array}{l}\text { Small number or participants or } \\
\text { interviewees, selected purposively } \\
\text { (non-randomly) }\end{array}$ & $\begin{array}{l}\text { Large sample size of representative } \\
\text { cases }\end{array}$ \\
\cline { 2 - 4 } & $\begin{array}{l}\text { Referred to as participants or inter- } \\
\text { viewees }\end{array}$ & $\begin{array}{l}\text { Referred to as respondents or sub- } \\
\text { jects }\end{array}$ \\
\hline Data collection methods & $\begin{array}{l}\text { In-depth interviews, observation, } \\
\text { group discussions }\end{array}$ & $\begin{array}{l}\text { Population surveys, opinion polls, exit } \\
\text { interviews }\end{array}$ \\
\hline Analysis & Analysis is interpretive & $\begin{array}{l}\text { Analysis is statistical } \\
\text { Outcome }\end{array}$ \\
\hline $\begin{array}{l}\text { To identify and explain behavior, } \\
\text { beliefs, or actions }\end{array}$ & $\begin{array}{l}\text { To identify prevalence, averages and } \\
\text { patterns in data. To generalize to a } \\
\text { broader population }\end{array}$ \\
\hline
\end{tabular}

The quantitative research component concerns the results of the HLS-EU survey. The collection of these data was a collective effort by the different partners of the HLS-EU project consortium, leading to a large database of 8000 respondents providing data on the status of health literacy, its components, its main determinants and its impact on health and well-being for eight different European countries. The statistical analysis of these quantitative data was delegated to colleagues at the Ludwig Boltzmann Institute Health Promotion in Austria, as part of a specific work package in the HLS-EU project ${ }^{1}$.

The sub-studies primarily involved qualitative research methods. This methodological approach was considered the most appropriate given the explorative nature of the research questions concerned. Indeed, according to Hennink, Hutter and Bailey the purpose of qualitative research is to understand or explain behavior and beliefs; identify processes and understand the context of people's experiences, and to achieve depth of information, rather than breadth. Data are textual and data analysis is interpretive (Hennink et al., 2011). Hence, the qualitative research component refers to the conceptual contributions in terms of the new definition, and several frameworks on e.g.

\footnotetext{
${ }^{1}$ I would like to thank Jürgen Pelikan, Florian Röthlin and Kristin Ganahl of the Ludwig Boltzmann Institute Health Promotion in Austria for their statistical analysis of the HLS-EU data
} 
health literacy and its antecedents and consequences as well as the grounded theory generated on health literacy and CSR. The stakeholder analysis in Denmark as well as the scope study on citizen consultations and health literacy is also rooted in the qualitative tradition.

In most cases the research was conducted with colleagues in several ongoing health literacy projects such as the European Health Literacy project (HLS-EU); the Collaborative Venture on Business Action on Health Literacy; the Survey on Citizen's Consultation on the Right to Protection of Health by Council of Europe besides collaboration with colleagues at Maastricht University, Deakin University in Australia, Copenhagen and Aarhus Universities in Denmark.

\section{Aim and outline of the dissertation}

The dissertation is organised around three parts based on eleven articles that are either published or submitted to scientific journals, or summaries of project publications. Because of this choice to structure the dissertation on the basis of publications rather than writing a monograph, a certain overlap of content occurs between the articles. In particular, the paragraphs referring to the definition of health literacy and the results of the European Health Literacy Study will be repeated in most of the articles. Yet, I am convinced that this repetition will not disturb the comprehension of the results provided in each of the articles. Since some of the articles have already been published, I have decided to keep the published format. As a result, the chapters do not follow the same format throughout the dissertation. However, the reference system has been modified and made homogenous for all articles to enhance readability. For clarification, while my name is Kristine Sørensen spelled in Danish, the name appears in English spelling as Kristine Sorensen in the referenced journals.

The first part focuses on the conceptual definition of health literacy and on efforts to conceptually define health literacy for public health in a multicultural and multilingual European context. This part starts with a review article concerning the definition and concepts of health literacy. It is followed by an article on how health literacy can be translated to 29 European languages, presenting also a European glossary on health literacy. The second part focuses on the operationalization of health literacy, demonstrating how it can be measured to assess the level of health literacy at population level. The first article of this part introduces the HLS-EU-Q, the questionnaire that was developed on the basis of the conceptual model elaborated jointly to conduct a comparative study on health literacy in eight countries in Europe. It is followed by an article presenting the main results of the European Health Literacy Survey, with data on health literacy in the eight countries involved. The third part of the dissertation focuses on the way to enhance health literacy in Europe, by exploring how to develop health literate systems, businesses and societies. Concerning health literate systems, a first article identifies the stakeholders involved in strengthening health literacy, based on 
an example from Denmark. This is followed by an article that discusses the changing roles of health professionals when health literacy act as catalyst for knowledge exchange. Next, three articles describe how to develop health literate businesses by integrating health literacy as part of corporate social responsibility and health at work. The section is concluded with two articles that explore ways to develop health literate societies, one focusing on the ethical aspects of health literacy and one on the use of citizen consultations to enhance co-management of health. The dissertation ends with a general discussion of the research, leading to the conclusion that health literacy is an neglected European public health disparity, which requires more attention, as well as mobilization of resources and capacity building in research, policy and practice in order to search for solutions to the findings; which reveals that a large part of the populations demonstrates limited or insufficient levels of health literacy. I will now describe each part in more detail.

\section{Part 1 Defining health literacy}

The first part provides an overview of how health literacy can be conceptually defined and translated. Chapter 2 gives a systematic review of the literature regarding health literacy definitions and conceptual models. Although its importance is increasingly recognized, there is no consensus about the definition of health literacy or about its conceptual dimensions, which limits the possibilities for measurement and comparison. A critical examination of existing definitions and models, allowed for the development of an integrated definition and conceptual model of health literacy, capturing its most comprehensive evidence-based dimensions and identifying its main determinants and consequences. Health literacy enables people to access, understand, appraise and apply information in all forms to make decisions on health in everyday life. It is influenced by personal, situational, social and environmental determinants and has an effect on health service use, health behavior, participation in society and health equity. Chapter 3 expands on the challenge of translating the term 'health literacy' into European languages. A two-step linguistic analysis is presented that includes a source and receptor analysis, which makes it possible to discuss the characteristics of the translations derived from 29 European languages for the purpose of this study. Essentially, a polarization is seen which refers to different health literacy discourses, namely: a primary understanding of 'health literacy' as being 'functional' and focusing on the abilities to read and comprehend information; or a competence-related health literacy perspective, focusing on health literacy as a life skill related to empowerment and broader capacities. It is evident that the choice of translation is an important factor for the valorization of health literacy in terms of research, policy and practice. 


\section{How can health literacy be defined, measured and advanced in Europe?}
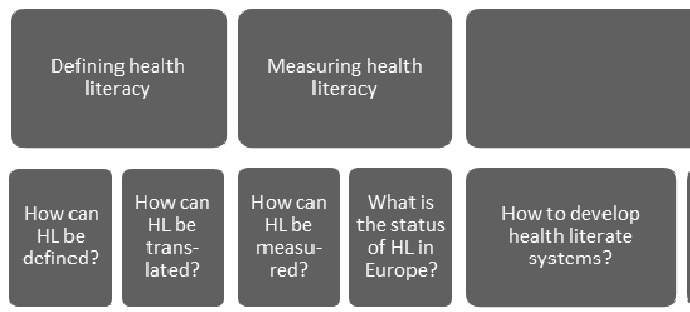

Advancing health literacy
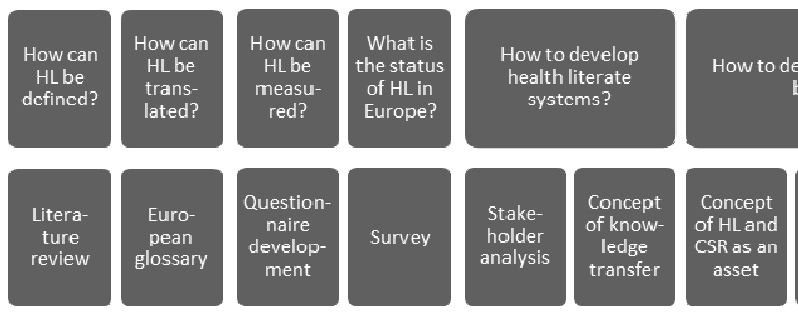

Advacing

Litera-

ture
review

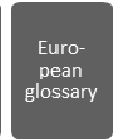

Figure 1.3: Overview of research questions and research designs to explore how health literacy can be defined, measured and advanced in Europe.

\section{Part 2 Measuring health literacy in populations}

The second part of the dissertation explores the measurement of health literacy at population level. Chapter 4 presents the process of developing a survey tool in alignment with the integrated definition and conceptual model of health literacy arrived at in chapter 2. To develop a new measurement tool, called the European Health Literacy Questionnaire (HLS-EU-Q), a comprehensive process was followed which included a Delphi procedure, a pre-test, a field test, an expert consultation and a plain language assessment. The tool assesses the abilities of individual in terms of finding, understanding, appraising and applying information in order to take decisions concerning healthcare, disease prevention and health promotion. Chapter 5 presents the results of the use of the HLS-EU-Q tool in the European Health Literacy Survey, which involved the collection of data on health literacy on representative samples of the population in eight European countries: Austria, Bulgaria, Germany (North-Rhine Westphalia), Greece, Ireland, the Netherlands, Poland and Spain. While the survey results highlight that across the eight countries on average $47 \%$ of the population face limited health literacy, the prevalence of low health literacy differs considerably between the countries. Moreover, a social gradient in health literacy can be detected, which indicates that health literacy levels not only differ between countries, but also within countries and they are associated with socio-economic conditions. So, limited health literacy is not only a challenge in marginalized populations, but a general public health threat to some populations in Europe. 


\section{Part 3 Advancing health literacy in Europe}

The third part of the dissertation part expands on the possibility for different stakeholders and sectors to advance health literacy in Europe. It is divided into three subsections. The first sub-section focuses on the development of health literate systems, exploring which stakeholders are involved in the field of health literacy. This is exemplified by a case-study presented in chapter 6 identifying the movers and shakers of health literacy in Denmark, a country that did not take part in the European Health Literacy study. The study is based on a stakeholder analysis and an initial power analysis indicating a power vacuum and lack of leadership in spite of a wide range of stakeholders acting in the emerging cross-sectorial and inter-disciplinary health literacy field in Denmark. In Chapter 7, the capacity of health literacy as catalyst for knowledge transfer among health experts is explored. The chapter discusses how health literacy applies to other new areas such as the complexity and novelty of public health genomics, which poses a challenge for effective and responsible translation of information to the benefit of population health. The idea of health professionals as knowledge-brokers and of 'nudges' (Taler \& Sunstein, 2008) is presented, along with a call for organizational change inspired by the Google paradigm (Jarvis, 2009).

The second sub-section explores how to develop health literate businesses. Chapter 8 introduces health literacy as an asset for corporate social responsibility by exploring the place of health literacy in relation with the concepts of corporate social responsibility and corporate value. The call for smart growth launched by the European Commission in the Europe 2020 strategy makes it important for businesses to engage not only in the safety of their employees, but also in their well-being. It is then argued that health literacy can play an essential role in this process by being build-in to business strategies and not as add-on temporary health projects. The focus of Chapter 9 is the outcome of a qualitative study made in collaboration with CSR Europe. The study explores how international companies can integrate health literacy as part of their social practice, and sees if best practices could be identified for a wider knowledge exchange among businesses in Europe. It is revealed that the investment in health literacy is not yet a common approach and that health projects are generally were implemented but not transparently grounded in terms of needs, corporate strategies, finance and other resources. It is argued that a mind shift is necessary to strengthen health literacy not only in the fitness room but also in the boardroom, to ensure the integration of health literacy as a strategic management choice that can enhance wellbeing at work. Following the discussions of health literacy as an asset in Chapter 8 and the gaps identified in Chapter 9, this chapter presents a new framework for companies called "Blueprint for Business Actions on Health Literacy". The framework has been developed in conjunction with the Collaborative Venture on Health Literacy under the umbrella of CSR Europe, the leading business network on corporate social responsibil- 
ity in Europe (CSR Europe, n.d.-a). The study provides a consistent and evident-based approach for businesses to apply as part of their corporate social responsibility.

The third sub-section in part 3 explores the development of health literate societies. Chapter 11 focuses on the ethical scope of health literacy, which is discussed in terms of health and inequalities, quality of life, social justice, human rights and the capabilities approach by Martha Nussbaum. The scoping study illustrates how ethics play an essential role in the normative application of health literacy in policy, research and practice. Chapter 12 refers to a new model for democratizing health through a people-centered approach that is grounded in health literacy and citizen consultations. The study was commissioned by and conducted in cooperation with the Council of Europe. A new framework is proposed and study results illustrate how far member states of the Council of Europe have succeeded in setting up people-centered systems that supports health literacy and involve citizens in decision-making.

The dissertation is concluded with chapter 13, which summarizes and discusses the main findings of the dissertation. It draws the conclusion that the issue of limited health literacy is a neglected European public health disparity. Furthermore, it reflects on the methodology of the overall research and offers considerations and recommendations for further research, policy development and practice on health literacy. 



\section{PART 1}

Defining health literacy

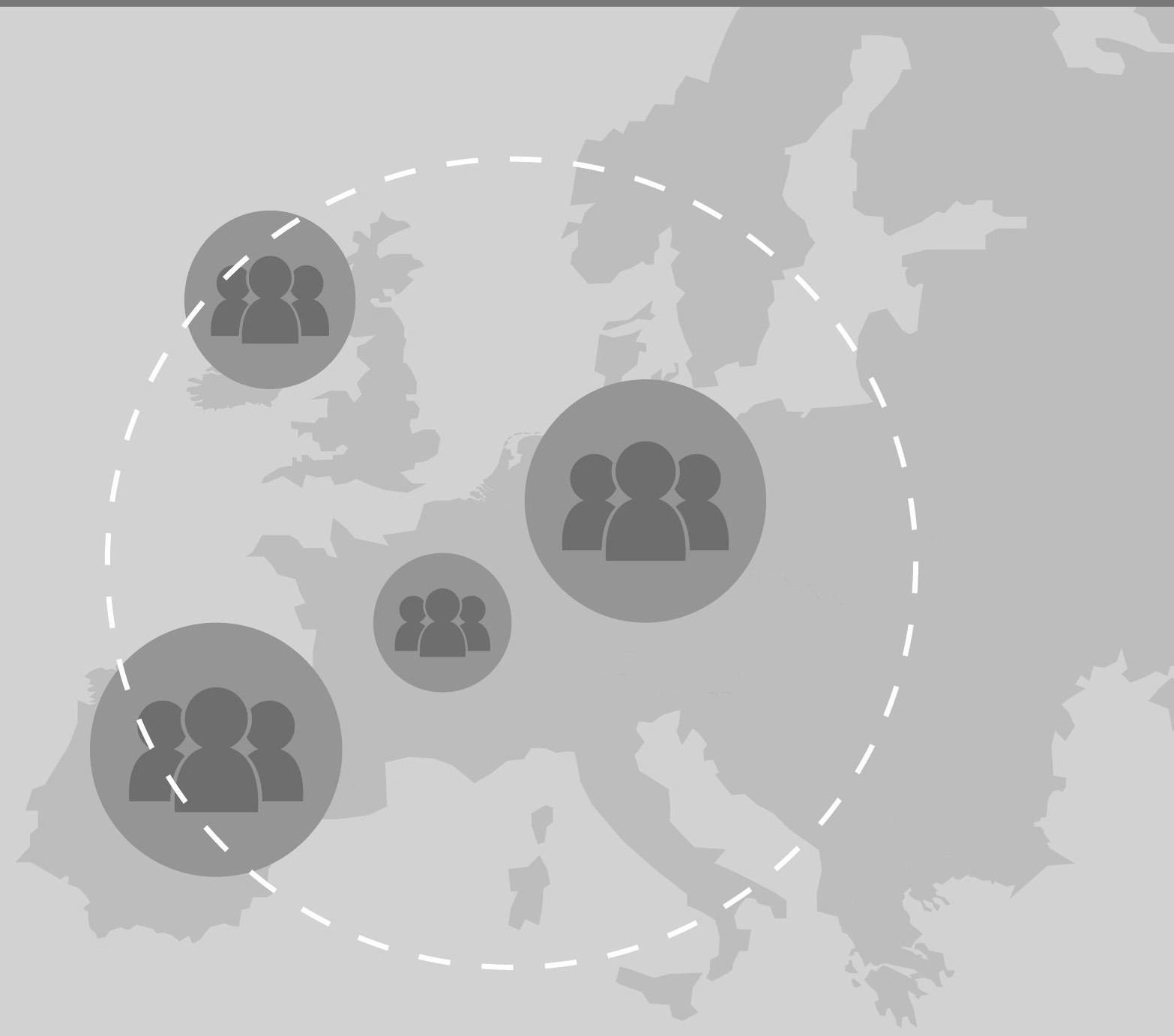


Eventually, all models are wrong, but some are useful.

Box \& Draper 


\section{CHAPTER 2}

\section{Health literacy - a review of definitions and models}

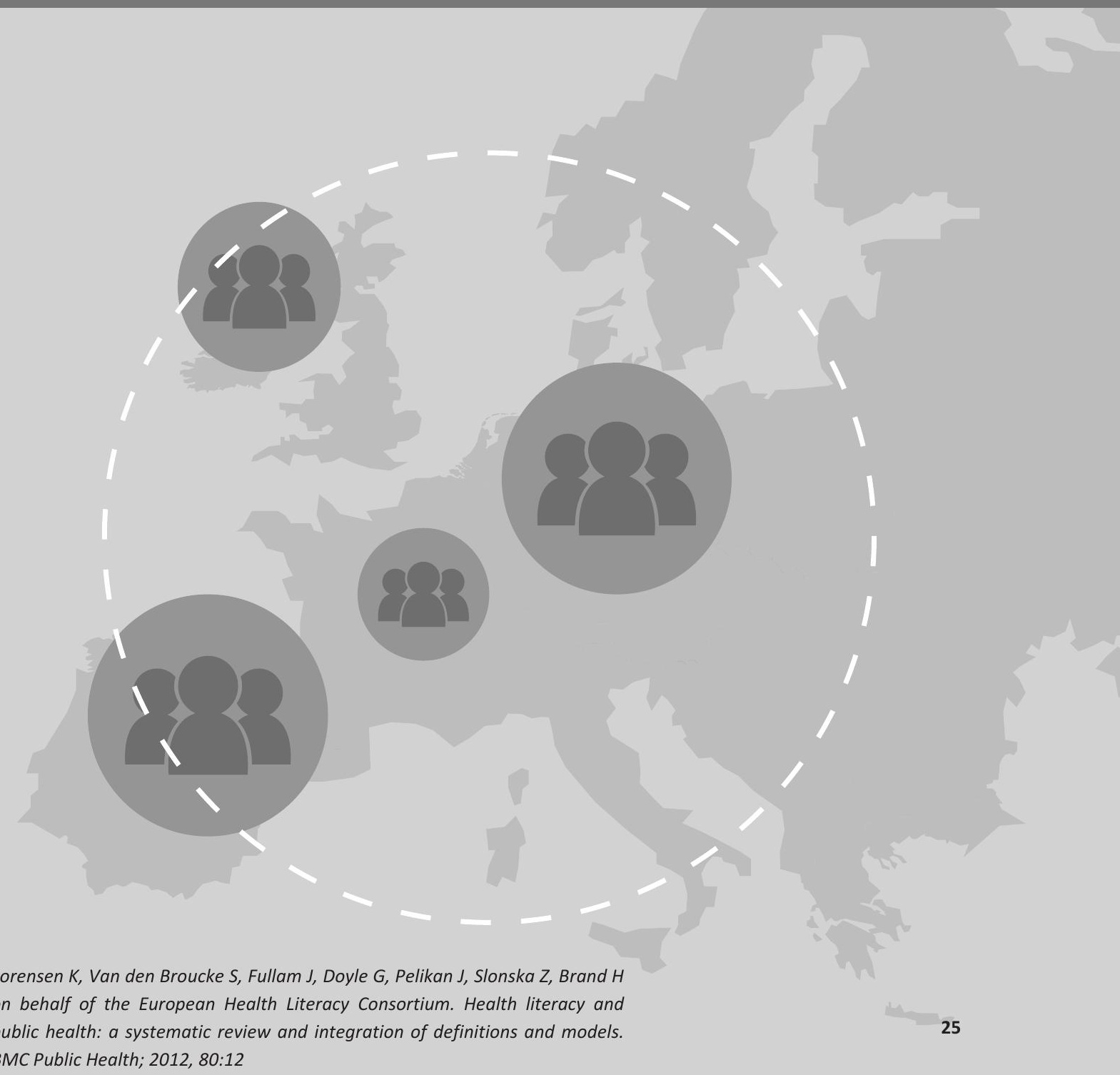




\section{Abstract}

Background Health literacy concerns the knowledge and competences of persons to meet the complex demands of health in modern society. Although its importance is increasingly recognised, there is no consensus about the definition of health literacy or about its conceptual dimensions, which limits the possibilities for measurement and comparison. The aim of the study is to review definitions and models on health literacy to develop an integrated definition and conceptual model capturing the most comprehensive evidence-based dimensions of health literacy.

Methods A systematic literature review was performed to identify definitions and conceptual frameworks of health literacy. A content analysis of the definitions and conceptual frameworks was carried out to identify the central dimensions of health literacy and develop an integrated model.

Results The review resulted in seventeen definitions of health literacy and twelve conceptual models. Based on the content analysis, an integrative conceptual model was developed containing twelve dimensions referring to the knowledge, motivation and competencies of accessing, understanding, appraising and applying health-related information within the healthcare, disease prevention and health promotion setting, respectively.

Conclusions Based upon this review, a model is proposed integrating medical and public health views of health literacy. The model can serve as a basis for developing health literacy enhancing interventions and provide a conceptual basis for the development and validation of measurement tools, capturing the different dimensions of health literacy within the healthcare, disease prevention and health promotion settings. 


\section{Background}

$\mathrm{H}$ ealth literacy is a term introduced in the 1970s (Simonds, 1974) and of increasing importance in public health and healthcare. It is concerned with the capacities of people to meet the complex demands of health in a modern society (Kickbusch \& Maag, 2008). To be health literate means placing one's own health and that of one's family and community into context, understanding which factors are influencing it and knowing how to address them. An individual with an adequate level of health literacy has the ability to take responsibility for one's own health as well as one's family health and community health (McQueen et al., 2007). It is important to distinguish health literacy from literacy in general. According to the United Nation Education, Science and Culture Organization (UNESCO) during its history in English, the word 'literate' mostly meant to be 'familiar with literature' or in general terms 'well educated, learned'. While maintaining its broader meaning of being knowledgeable or educated in a particular area, during the late nineteenth century it has also come to refer to the abilities to read and write text. In recent years four understandings of literacy have appeared from the debate of the notion: 1) literacy as an autonomous set of skills; 2) literacy as applied, practiced and situated; 3 ) literacy as a learning process and 4) literacy as text. The focus is furthermore broadening so that literacy is not only referring to individual transformation, but also to contextual and societal transformation in terms of linking health literacy to economic growth and socio-cultural and political change (UNESCO, 2005).

The same development can be traced in the realm of health literacy. For some time most emphasis was given to health literacy as the ability to handle words and numbers in a medical context. In recent years the concept is broadening to also understanding health literacy as involving the simultaneous use of a more complex and interconnected set of abilities, such as reading and acting upon written health information, communicating needs to health professionals and understanding health instructions (Peerson \& Saunders, 2009). American studies in the 1990s linked literacy to health, showing an association between low literacy and decreased medication adherence, knowledge of disease and self-care management skills (Parker, 2000). The 2003 National Assessment of Adult Literacy (NAAL), which measured the English literacy of American adults (people age 16 and older) included questions related to health and revealed the consequences of limited literacy on health and healthcare (Kutner, Greenberg, Jin, \& Paulsen, 2006a).

A report from the Institute of Medicine indicates that nearly half of the American adult population may have difficulties in acting on health information (NielsenBohlman, Panzer, \& Kindig, 2004). This finding has been referred to as the "health literacy epidemic" (Davis \& Wolf, 2004). In response, measures have been taken to 
ensure better health communication through establishing health literacy guidelines (Health Literacy Innovations, n.d.) and a trans-disciplinary approach has been encouraged to improve health literacy (Lloyd, Ammary, Epstein, Johnson, \& Rhee, 2006). To support this approach, the American Medical Association recommends four areas for research: health literacy screening; improving communication with low-literacy patients; costs and outcomes of poor health literacy and causal pathways of how poor health literacy influences health (Ad Hoc Committee on Health Literacy for the Council on Scientific Affairs, 1999; McCray, 2005). The research literature on health literacy has expanded exponentially, with nearly 5,000 PubMed-listed publications to date (Primo November 2011), the majority of which have been published since 2005 (Ishikawa \& Kiuchi, 2010; Peerson \& Saunders, 2009) and it is evident that health literacy is being explored within different disciplines and with different approaches, e.g. looking at the role of health educators in promoting health literacy (Tappe \& Galer-Unti, 2001); public health literacy for lawyers (Robbins, 2003), health communication (Parker \& Gazmararian, 2003), the prevalence of limited health literacy (Paasche-Orlow, Parker, Gazmararian, Nielsen-Bohlman, \& Rudd, 2005a) and health literacy as an empowerment tool for low-income mothers (Porr, Drummond, \& Richter, 2006).

While until recently the interest in health literacy was mainly concentrated in the United States and Canada, it has become more internationalized over the past decade (Paasche-Orlow, 2009). Research on health literacy has taken place in e.g. Australia (Adams et al., 2009; Barber et al., 2009), Korea (T. W. Lee, Kang, Lee, \& Hyun, 2009), Japan (Ishikawa, Nomura, Sato, \& Yano, 2008), the UK (Ibrahim et al., 2008), the Netherlands (Twickler et al., 2009) and Switzerland (J. Wang \& Schmid, 2007). Although the EU produced less than a third of the global research on health literacy between 1991 and 2005 (Kondilis et al., 2008, 2006), the importance of the issue is increasingly recognized in European health policies. As a case in point, health literacy is explicitly mentioned as an area of priority action in the European Commission's Health Strategy 2008-2013 (European Commission, 2007). It is linked to the core value of citizen empowerment and the priority actions proposed by the European Commission include the promotion of health literacy programs for different age groups.

However, with the proliferation of health literacy research and policy measures, it becomes clear that there is no unanimously accepted definition of the concept. Moreover, the constituent dimensions of health literacy remain disputed and attempts to operationalize the concept vary widely in scope, method and quality. As a result, it is very difficult to compare findings with regard to health literacy emerging from research in different countries.

The current article aims to address this issue by offering a systematic review of existing definitions and concepts of health literacy as reported in the international literature, by identifying the central health literacy dimensions, the target group as 
well as antecedents and consequences if explained in order to develop an integrated definition and conceptual model capturing the most comprehensive evidence-based dimensions of health literacy.

\section{Method}

A systematic review in Medline, Pubmed and Web of Science was performed by two independent research teams in autumn 2009 and spring 2010 and the results compared and combined to obtain information regarding two research questions: 1) How is health literacy defined? and 2) How can health literacy be conceptualized? To retrieve studies, seventeen keywords (definition, model, concept, dimension, framework, conceptual framework, theory, analysis, qualitative, quantitative, competence, skill, "public health", communication, information, functional, critical) were combined (using the Boolean operator and) with the search terms "health literacy", "health competence" and health competence (without quotes). Combinations of the keywords with health literacy (without quotes) produced a list of studies that was too wide for the purpose of this study and therefore not used for the review. From the resulting list, studies were selected for inclusion in the review on the basis of their abstracts. Eligible studies were included which met the following inclusion criteria: 1) written in English; 2) concerned with health literacy in a developed country and 3) offering relevant content with regard to the definition or conceptualization of health literacy, or a combination of these issues.

The eligible literature was scanned for definitions and a content analysis was performed in three steps: firstly, the definitions were coded and condensed by two research teams working independently. Secondly, the analysis was discussed with a panel of health experts from the European Health Literacy Consortium. In a third step, the feedback was elaborated by the original research team and integrated in a final analysis yielding a condensed 'all-inclusive' definition of health literacy capturing the different meanings and dimensions presented in the literature. In addition, an overview of all models from the eligible literature was conducted; the models were compared according to dimensions, target groups and antecedents as well as consequences if explained. As a result a new conceptual model was drafted capturing the most comprehensive core dimensions of health literacy identified as well as its antecedents and consequences. 


\section{Results}

The combination of the key words with the three search terms resulted in the initial identification of 170 publications. Additional publications were found by reference tracking and included in the review. Based on the application of the inclusion criteria to the abstracts, nineteen publications were retrieved which explicitly dealt with the definition of health literacy, and twelve with conceptual frameworks of health literacy.

Definitions of health literacy

From the nineteen publications focusing specifically on definitions of health literacy seventeen explicit definitions could be derived (Table 2.1). Of these definitions, the ones by the American Medical Association (Ad Hoc Committee on Health Literacy for the Council on Scientific Affairs, 1999), the Institute of Medicine (Nielsen-Bohlman et al., 2004) and WHO (Nutbeam, 1998) are cited most frequently in the eligible literature. A shared characteristic of these definitions is their focus on individual skills to obtain, process and understand health information and services necessary to make appropriate health decisions. However, recent discussions on the role of health literacy highlight the importance of moving beyond an individual focus and of considering health literacy as an interaction between the demands of health systems and the skills of individuals. In fact the Institute of Medicine report already alluded that "health literacy is a shared function of social and individual factors, which emerges from the interaction of the skills of individuals and the demands of social systems" (NielsenBohlman et al., 2004). More recently, Kwan (Kwan et al., 2006) and Pleasant (Pleasant, 2008) underscored the importance of skills and abilities on the part of all parties involved in communication and decisions about health, including patients, providers, health educators and lay people. This broader view is presented in the definition proposed by Zarcadoolas, Pleasant and Greer (Zarcadoolas, Pleasant, \& Greer, 2003), who state that a health literate person is able to apply health concepts and information to novel situations, and to participate in ongoing public and private dialogues about health, medicine, scientific knowledge and cultural beliefs. Freedman and her collegues (Freedman et al., 2009) argue that the medical perspective on factors influencing people's health should be shifted towards a societal level and that a distinction must be made between public and individual health literacy. Public health literacy can be found when the conceptual foundations of health literacy are in place in a group or community. 
Table 2.1 Definitions of health literacy

\begin{tabular}{lll}
\hline \# & Author (year) & Health literacy definition \\
\hline 1 & WHO (1998) & $\begin{array}{l}\text { "The cognitive and social skills which determine the motivation and ability of } \\
\text { individuals to gain access to understand and use information in ways which } \\
\text { promote and maintain good health" (Nutbeam, 1998) }\end{array}$ \\
\hline 2 American Medical & $\begin{array}{l}\text { "The constellation of skills, including the ability to perform basic reading and } \\
\text { numeral tasks required to function in the healthcare environment" (Ad Hoc } \\
\text { Committee on Health Literacy for the Council on Scientific Affairs, 1999) }\end{array}$ \\
\hline
\end{tabular}

3 Nutbeam (2000) "The personal, cognitive and social skills which determine the ability of individuals to gain access to, understand, and use information to promote and maintain good health" (Nutbeam, 2000a)

4 Institute of Medicine "The individuals' capacity to obtain, process and understand basic health (2004) information and services needed to make appropriate health decisions" (Nielsen-Bohlman et al., 2004)

5 Kickbusch, Wait \& Maag (2005)

"The ability to make sound health decision(s) in the context of everyday life-at home, in the community, at the workplace, the healthcare system, the market place and the political arena. It is a critical empowerment strategy to increase people's control over their health, their ability to seek out information and their ability to take responsibility" (Kickbusch et al., 2005)

6 Zarcadoolas, Pleasant "The wide range of skills, and competencies that people develop to seek out, \& Greer $(2003,2005$, comprehend, evaluate and use health information and concepts to make 2006) informed choices, reduce health risks ad increase quality of life" (Zarcadoolas et al., 2003; Zarcadoolas, Pleasant, \& Greer, 2005, 2012)

7 Paasche-Orlow \& “An individual's possession of requisite skills for making health-related deciWolf (2007) sions, which means that health literacy must always be examined in the context of the specific tasks that need to be accomplished. The importance of a contextual appreciation of health literacy must be underscored" (PaascheOrlow \& Wolf, 2007)

8 EU (2007) "The ability to read, filter and understand health information in order to form sound judgments" (European Commission, 2007)

9 Pavlekovic (2008) "The capacity to obtain, interpret and understand basic health information and services and the competence to use such information to enhance health" (Pavlekovic, 2008)

10 Rootman \& GordonElbihbety (2008)

"The ability to access, understand, evaluate and communicate information as a way to promote, maintain and improve health in a variety of settings across the life course" (Rootman \& Gordon-El-Bihbety, 2008)

11 Ishikawa \& Yano "The knowledge, skills and abilities that pertain to interactions with the (2008) healthcare system" (Ishikawa \& Yano, 2008)

12 Mancuso (2008) "A process that evolves over one's lifetime and encompasses the attributes of
capacity, comprehension, and communication. The attributes of health literacy
are integrated within and preceded by the skills, strategies, and abilities em-
bedded within the competencies needed to attain health literacy" (Mancuso,
2008) 
Table 2.1 Definitions of health literacy (continued)

\begin{tabular}{lll}
\hline \# & Author (year) & Health literacy definition \\
\hline 13 Australian Bureau of & "The knowledge and skills required to understand and use information relating \\
& $\begin{array}{l}\text { to health issues such as drugs and alcohol, disease prevention and treatment, } \\
\text { safety and accident prevention, first aid, emergencies, and staying healthy" } \\
\text { (Adams et al., 2009) }\end{array}$ \\
\hline 14 Yost et al. (2009) & "The degree to which individuals have the capacity to read and comprehend \\
& $\begin{array}{l}\text { health-related print material, identify and interpret information presented in } \\
\text { in order to make appropriate health and care decisions" (Yost et al., 2009) }\end{array}$ \\
\hline 15 Adams et al. (2009) & $\begin{array}{l}\text { "The ability to understand and interpret the meaning of health information in } \\
\text { written, spoken or digital form and how this motivates people to embrace or } \\
\text { disregard actions relating to health" (Adams et al., 2009) }\end{array}$ \\
\hline 16 Adkins et al. (2009) & $\begin{array}{l}\text { "The ability to derive meaning from different forms of communication by using } \\
\text { a variety of skills to accomplish health-related objectives" (Ross Adkins \& } \\
\text { Corus, 2009) }\end{array}$ \\
\hline 17 Freedman et al. & $\begin{array}{l}\text { "The degree to which individuals and groups can obtain process, understand, } \\
\text { (2009) }\end{array}$ \\
\hline
\end{tabular}

The content analysis on the definitions yielded six clusters representing: 1) competence, skills, abilities; 2) actions; 3 ) information and resources; 4) objective; 5) context and 6) time as outlined in Table 2.2. Accordingly each cluster was carefully examined, discussed and condensed by the research team and the resulting chosen terms and notions were combined to yield a new 'all inclusive' comprehensive definition capturing the essence of the seventeen definitions identified in the literature:

Health literacy is linked to literacy and entails people's knowledge, motivation and competences to access, understand, appraise, and apply health information in order to make judgments and take decisions in everyday life concerning healthcare, disease prevention and health promotion to maintain or improve quality of life during the life course.

This definition encompasses the public health perspective and can easily be specified to accommodate an individual approach by substituting the three domains of health "healthcare, disease prevention and health promotion" with "being ill, being at risk and staying healthy".

\section{Concepts of health literacy}

Table 2.3 lists the publications which provide a conceptual model of health literacy. From this overview, two issues become apparent. Firstly, health literacy is a multidimensional concept and consists of different components. Secondly, most conceptual 
models not only consider the key components of health literacy, but also identify the individual and system-level factors that influence a person's level of health literacy, as well as the pathways that link health literacy to health outcomes.

\section{Dimensions of health literacy}

The distinction between medical and public health literacy (Freedman et al., 2009) is reflected in the identification of different dimensions. Within the definition of health literacy as individual capacities, the Institute of Medicine (Nielsen-Bohlman et al., 2004) consider cultural and conceptual knowledge, listening, speaking, arithmetical, writing and reading skills as the main components of health literacy. Speros (Speros, 2005) also identifies reading and numeracy skills as the defining attributes, but adds comprehension, the capacity to use health information in decision making and successful functioning in the role of healthcare consumer as dimensions. Baker (Baker, 2006). divides health literacy into health related print literacy and health related oral literacy, while Paashe-Orlow and Wolf (Paasche-Orlow \& Wolf, 2007)] distinguish between listening, verbal fluency, memory span and navigation. Lee et al. (S.-Y. D. Lee, Arozullah, \& Cho, 2004) identify four interrelated factors: 1) disease and self-care knowledge; 2) health risk behavior; 3) preventive care and physician visits and 4) compliance with medication. While these defining elements of health literacy vary considerably they all concern cognitive capabilities, skills and behaviors which reflect an individual's capacity to function in the role of a patient within the healthcare system.

Proponents of the population health literacy view, on the other hand, extend the concept to include dimensions which go beyond individual competences and the medical context. The prototypical model is that of Nutbeam (Nutbeam, 2006), which distinguishes between three levels of health literacy: 1) Functional health literacy refers to the basic skills in reading and writing that are necessary to function effectively in everyday situations, broadly comparable with the content of "medical" health literacy referred to above; 2 ) Interactive health literacy refers to more advanced cognitive and literacy skills which, together with social skills, can be used to actively participate in everyday situations, extract information and derive meaning from different forms of communication, and apply this to changing circumstance; 3) Critical health literacy refers to more advanced cognitive skills which, together with social skills, can be applied to critically analyze information and use this to exert greater control over life events and situations. The different levels represent levels of knowledge and skills that progressively support greater autonomy and personal empowerment in health related decision-making, as well as engagement with a wider range of health knowledge that extends from personal health management to the social determinants of health (Nutbeam, 2008). 
Table 2.2 The six clusters identified when condensing the definitions from the literature review

\begin{tabular}{|c|c|c|c|c|c|}
\hline $\begin{array}{l}\text { Competence / skills } \\
\text { / abilities }\end{array}$ & Action & Information & Objective & Context & Time \\
\hline $\begin{array}{l}\text { Skills } \\
\text { Possession of } \\
\text { requisite } \\
\text { skills/Constellation } \\
\text { of skills/Wide } \\
\text { range of skills } \\
\text { Cognitive skills } \\
\text { Social skills } \\
\text { Personal skills } \\
\text { The ability } \\
\text { The capacity } \\
\text { The knowledge } \\
\text { The competencies } \\
\text { Motivation } \\
\text { Comprehension } \\
\text { Communication }\end{array}$ & $\begin{array}{l}\text { To gain access } \\
\text { To understand } \\
\text { To use } \\
\text { To perform basic } \\
\text { reading and nu- } \\
\text { merical tasks } \\
\text { To obtain } \\
\text { To process } \\
\text { To seek out } \\
\text { To comprehend } \\
\text { To evaluate } \\
\text { To read } \\
\text { To filter } \\
\text { To find } \\
\text { To appraise } \\
\text { To communicate } \\
\text { To interpret } \\
\text { To identify } \\
\text { To perform arith- } \\
\text { metic operations } \\
\text { To embrace or } \\
\text { disregard actions } \\
\text { To derive meaning } \\
\text { To act } \\
\text { To make sound } \\
\text { decisions/to make } \\
\text { health-related } \\
\text { decisions } \\
\text { To take responsi- } \\
\text { bility } \\
\text { To pertain interac- } \\
\text { tions } \\
\text { To attain capacity, } \\
\text { comprehension } \\
\text { and communica- } \\
\text { tion }\end{array}$ & $\begin{array}{l}\text { Information } \\
\text { Health infor- } \\
\text { mation } \\
\text { Information } \\
\text { relating to } \\
\text { health } \\
\text { Basic health } \\
\text { information } \\
\text { Health-related } \\
\text { print-material } \\
\text { Information } \\
\text { presented in } \\
\text { graphical form } \\
\text { Health infor- } \\
\text { mation in } \\
\text { written, spo- } \\
\text { ken or digital } \\
\text { form } \\
\text { Different forms } \\
\text { of communica- } \\
\text { tion } \\
\text { Concepts } \\
\text { Services }\end{array}$ & $\begin{array}{l}\text { Promote and } \\
\text { maintain good } \\
\text { health } \\
\text { To function in the } \\
\text { healthcare envi- } \\
\text { ronment } \\
\text { To make appro- } \\
\text { priate health } \\
\text { decisions } \\
\text { A critical empow- } \\
\text { erment strategy } \\
\text { to increase peo- } \\
\text { ple's control over } \\
\text { their health } \\
\text { To make informed } \\
\text { choices } \\
\text { Reduce health } \\
\text { risks } \\
\text { Increase quality of } \\
\text { life } \\
\text { To form sound } \\
\text { judgments } \\
\text { To engage in } \\
\text { demands of } \\
\text { different health } \\
\text { contexts } \\
\text { To promote } \\
\text { health } \\
\text { To enhance health } \\
\text { To improve health } \\
\text { To make appro- } \\
\text { priate health and } \\
\text { care decisions } \\
\text { To accomplish } \\
\text { health-related } \\
\text { objectives } \\
\text { To make public } \\
\text { health decisions } \\
\text { that benefit the } \\
\text { community }\end{array}$ & $\begin{array}{l}\text { Variety of settings } \\
\text { The healthcare } \\
\text { environment } \\
\text { Different health } \\
\text { contexts } \\
\text { Healthcare setting } \\
\text { Health related } \\
\text { contexts } \\
\text { The everyday life } \\
\text { at home, in the } \\
\text { community, at the } \\
\text { workplace, within } \\
\text { the healthcare } \\
\text { system, at the } \\
\text { market place and } \\
\text { within the political } \\
\text { arena } \\
\text { HL always related } \\
\text { to the context of } \\
\text { the specific tasks } \\
\text { needed to be } \\
\text { accomplished }\end{array}$ & $\begin{array}{l}\text { Across } \\
\text { the life } \\
\text { course } \\
\text { Evolves } \\
\text { over } \\
\text { lifetime }\end{array}$ \\
\hline
\end{tabular}

Manganello (Manganello, 2008) adds media literacy as the ability to critically evaluate media messages. Zarcadoolas et al. (Zarcadoolas et al., 2005) distinguish between fundamental literacy (skills and strategies involved in reading, speaking, writing and interpreting numbers); science literacy (the levels of competence with science and technology); civic literacy (abilities that enable citizens to become aware of public issues and become involved in the decision-making process); and cultural literacy (the 
ability to recognize and use collective beliefs, customs, world-view and social identity in order to interpret and act on health information).

In a similar vein, Freedman et al. (Freedman et al., 2009) identify three dimensions of public health literacy, each of which involves corresponding competences: 1) Conceptual foundations includes the basic knowledge and information needed to understand and take action on public health concerns; individuals and groups should be able to discuss core public health concepts, public health constructs and ecologic perspectives. 2) Critical skills relates to the skills necessary to obtain, process, evaluate and act upon information that is needed to make public health decisions that benefit the community; an individual or group should be able to obtain, evaluate and utilize public health information, identify public health aspects of personal and community concerns, and access who is naming and framing public health problems and solutions. 3 ) Civic orientation includes the skills and resources necessary to address health concerns through civic engagement; an individual or group should be able to articulate the uneven distribution of burdens and benefits of the society, evaluate who benefits and who is harmed by public health efforts, communicate current public health problems and address public health problems through civic action, leadership and dialogue. Mancuso (Mancuso, 2008) emphasizes that health literacy is a process that evolves over a person's lifetime and identify the attributes of health literacy to be capacity, comprehension and communication. 1) The Capacity skills related to health literacy include gathering, analyzing and evaluating health information for credibility and quality, working together, managing resources, seeking guidance and support, developing and expressing a sense of self, creating and pursuing a vision and goals, and keeping pace with change. Oral language skills are also considered essential. Social skills and credentials such as reading, listening, analytical, decision-making, and numerical abilities are important as well to advocate for oneself, to act on health information and to negotiate and navigate within the health-care system. 2) Comprehension is a complex process based on the effective interaction of logic, language and experience and is crucial to the accurate interpretation of a myriad of information that is provided to the modern patient, such as discharge instructions, consent forms, patient education materials and medication directions. 3) Communication is how thoughts, messages or information are exchanged through speech, signals, writing or behavior. Communication involves inputs, decoding, encoding output, and feedback. Essential communication skills are reading with understanding, conveying ideas in writing, speaking so others can understand, listening actively and observing critically.

In conclusion, the range of factors that are considered as key components of health literacy is extensive and there is a wide variation between conceptual models. However, this diversity of views can to a large extent be reduced to two dimensions, notably the core qualities of health literacy (e.g., basic or functional, interactive and 
critical health literacy) and its scope and area of application (e.g., as a patient in healthcare, as a consumer at the market, as a citizen in the political arena or as a member of the audience in relation to the media).

Antecedents and consequences of health literacy

Apart from the dimensions of health literacy, the conceptual models summarized in Table 2.3 also give the main antecedents and consequences of health literacy outlined in the literature.

Table 2.3 Conceptual models of health literacy

\begin{tabular}{|c|c|c|c|c|}
\hline \# & Reference & Dimensions & Antecedents & Consequences \\
\hline 1 & $\begin{array}{l}\text { Nutbeam } \\
\text { (2000) }\end{array}$ & $\begin{array}{l}\text { - Functional health literacy } \\
\text { - Interactive health literacy } \\
\text { - Critical health literacy }\end{array}$ & $\begin{array}{l}\text { Health promotion ac- } \\
\text { tions (education, social } \\
\text { mobilization, advocacy) }\end{array}$ & $\begin{array}{l}\text { Individual benefits } \\
\text { - Improved knowledge of risks } \\
\text { - Compliance with prescribed } \\
\text { actions. Improved capacity to act } \\
\text { independently on knowledge } \\
\text { - Improved motivation and self- } \\
\text { confidence } \\
\text { - Improved individual resilience to } \\
\text { adversity } \\
\text { Community/social benefits } \\
\text { - Increased participation in popula- } \\
\text { tion health programs } \\
\text { - Improved capacity to influence } \\
\text { social norms and interact with } \\
\text { social groups. } \\
\text { - Improved capacity to act on social } \\
\text { and economic determinants of } \\
\text { health } \\
\text { - improved community empower- } \\
\text { ment }\end{array}$ \\
\hline 2 & $\begin{array}{l}\text { Lee et al. } \\
(2004)\end{array}$ & $\begin{array}{l}\text { - Disease and self-care } \\
\text { knowledge } \\
\text { - Health risk behavior } \\
\text { - Preventive care and } \\
\text { physician visits } \\
\text { - Compliance with medica- } \\
\text { tions }\end{array}$ & $\begin{array}{l}\text { - Social-economic status } \\
\text { - Gender } \\
\text { - Ethnicity } \\
\text { - Health insurance cov- } \\
\text { erage } \\
\text { - Disease severity } \\
\text { - Income discrepancy } \\
\text { - Ethnic composition of } \\
\text { the community }\end{array}$ & $\begin{array}{l}\text { - Health status } \\
\text { - Emergency care } \\
\text { - Hospitalization }\end{array}$ \\
\hline 3 & $\begin{array}{l}\text { Institute of } \\
\text { Medicine } \\
\text { (2004) } \\
\text { (Nielsen- } \\
\text { Bohlman et } \\
\text { al., 2004) }\end{array}$ & $\begin{array}{l}\text { - Cultural and conceptual } \\
\text { knowledge } \\
\text { - Listening } \\
\text { - Speaking } \\
\text { - Arithmetical skills } \\
\text { - Writing skills } \\
\text { - Reading skills }\end{array}$ & $\begin{array}{l}\text { - Education, culture and } \\
\text { language. } \\
\text { - Communication and } \\
\text { assessment skills of } \\
\text { people with whom } \\
\text { individuals interact for } \\
\text { health } \\
\text { - Ability of the media, } \\
\text { the marketplace, and } \\
\text { governmental agencies } \\
\text { to provide health infor- } \\
\text { mation in an appropriate } \\
\text { manner }\end{array}$ & Health outcomes and costs \\
\hline
\end{tabular}


Table 2.3 Conceptual models of health literacy (continued)

\begin{tabular}{|c|c|c|c|c|}
\hline \# & Reference & Dimensions & Antecedents & Consequences \\
\hline 4 & $\begin{array}{l}\text { Zarcadoolas } \\
\text { et al. (2005) }\end{array}$ & $\begin{array}{l}\text { - Fundamental literacy } \\
\text { Science literacy } \\
\text { - Civic literacy } \\
\text { Cultural literacy }\end{array}$ & $\begin{array}{l}\text { - Health status } \\
\text { - Demographic, sociopo- } \\
\text { litical, psychosocial and } \\
\text { cultural factors }\end{array}$ & $\begin{array}{l}\text { - Ability to apply information to } \\
\text { novel situations } \\
\text { - Ability to participate in public and } \\
\text { private dialogues about health, } \\
\text { medicine, scientific knowledge and } \\
\text { cultural beliefs }\end{array}$ \\
\hline 5 & $\begin{array}{l}\text { Speros } \\
(2005)\end{array}$ & $\begin{array}{l}\text { - Reading/numeracy skills } \\
\text { - Comprehension } \\
\text { - Capacity to use health } \\
\text { information in decision } \\
\text { making } \\
\text { - Successful functioning in } \\
\text { healthcare consumer role }\end{array}$ & $\begin{array}{l}\text { - Literacy } \\
\text { - Health-related experi- } \\
\text { ence }\end{array}$ & $\begin{array}{l}\text { - Improved self-reported health } \\
\text { status } \\
\text { - Lower healthcare costs } \\
\text { - Increased health knowledge } \\
\text { - Shorter hospitalization } \\
\text { - Less frequent use of healthcare } \\
\text { services }\end{array}$ \\
\hline 6 & $\begin{array}{l}\text { Baker } \\
(2006)\end{array}$ & $\begin{array}{l}\text { - Health-related print } \\
\text { literacy } \\
\text { - Health-related oral litera- } \\
\text { cy. }\end{array}$ & $\begin{array}{l}\text { - Health-related reading } \\
\text { fluency } \\
\text { - Health-related vocabu- } \\
\text { lary } \\
\text { - Familiarity with health } \\
\text { concepts } \\
\text { - Complexity and difficul- } \\
\text { ty of the printed and } \\
\text { spoken messages in the } \\
\text { healthcare environment }\end{array}$ & $\begin{array}{l}\text { - Acquisition of new knowledge } \\
\text { - More positive attitudes } \\
\text { - Greater self-efficacy Positive } \\
\text { health behaviors } \\
\text { - Better health outcomes }\end{array}$ \\
\hline 7 & $\begin{array}{l}\text { Paashe- } \\
\text { Orlow } \\
\& \text { Wolf } \\
(2007)\end{array}$ & $\begin{array}{l}\text { - Listening } \\
\text { - Verbal fluency } \\
\text { - Memory span } \\
\text { - Navigation. }\end{array}$ & $\begin{array}{l}\text { - Socioeconomic status } \\
\text { Occupation } \\
\text { - Employment status } \\
\text { Income } \\
\text { - Social support } \\
\text { - Culture and language } \\
\text { - Education } \\
\text { - Age } \\
\text { - Race/ethnicity } \\
\text { - Personal competences } \\
\text { such as vision, hearing, } \\
\text { verbal ability, memory } \\
\text { and reasoning }\end{array}$ & $\begin{array}{l}\text { - Access and utilization of } \\
\text { healthcare (influenced by patients' } \\
\text { navigation skills, self-efficacy and } \\
\text { perceived barriers, and by system's } \\
\text { complexity, acute care orientation } \\
\text { and tiered delivery model) } \\
\text { - Patient/provider interactions } \\
\text { (influenced patients' knowledge, } \\
\text { beliefs and participation in deci- } \\
\text { sion-making, and by providers' } \\
\text { communication skills, teaching } \\
\text { ability, time and patient-centered } \\
\text { care) } \\
\text { - Self care (influenced by patients' } \\
\text { motivation, problem-solving, self- } \\
\text { efficacy, knowledge/skills, and by } \\
\text { support technologies, mass media, } \\
\text { health education and resources) }\end{array}$ \\
\hline 8 & $\begin{array}{l}\text { Kickbusch \& } \\
\text { Maag } \\
(2008)\end{array}$ & $\begin{array}{l}\text { - Functional } \\
\text { - Interactive } \\
\text { - Critical }\end{array}$ & $\begin{array}{l}\text { - Education system } \\
\text { - Health-care system } \\
\text { - Culture/home and } \\
\text { community } \\
\text { - Work } \\
\text { - Politics } \\
\text { - Market }\end{array}$ & - Health outcomes and costs \\
\hline
\end{tabular}


Table 2.3 Conceptual models of health literacy (continued)

\begin{tabular}{|c|c|c|c|c|}
\hline \# & Reference & Dimensions & Antecedents & Consequences \\
\hline 9 & $\begin{array}{l}\text { Mancuso } \\
(2008)\end{array}$ & $\begin{array}{l}\text { - Capacity } \\
\text { - Comprehension } \\
\text { - Communication }\end{array}$ & $\begin{array}{l}\text { - Operational compe- } \\
\text { tence } \\
\text { - Interactive competence } \\
\text { - Autonomous compe- } \\
\text { tence } \\
\text { - Informational compe- } \\
\text { tence } \\
\text { - Contextual competence } \\
\text { - Cultural competence }\end{array}$ & $\begin{array}{l}\text { - Healthcare costs } \\
\text { - Knowledge of diseases and treat- } \\
\text { ments } \\
\text { - Self-management skills } \\
\text { - Ability to care for chronic condi- } \\
\text { tions } \\
\text { - Compliance } \\
\text { - Medical or medication treatment } \\
\text { errors } \\
\text { - Access to and use of healthcare } \\
\text { services. } \\
\text { - Use of expensive services such as } \\
\text { emergency care and inpatient } \\
\text { admissions. } \\
\text { - Prevention and screening health- } \\
\text { promoting behaviors } \\
\text { - Health status, defined as physical } \\
\text { illness or perceptions of illness, } \\
\text { disease or impairment }\end{array}$ \\
\hline 10 & $\begin{array}{l}\text { Manganello } \\
(2008)\end{array}$ & $\begin{array}{l}\text { - Functional health literacy } \\
\text { - Interactive health literacy } \\
\text { - Critical health literacy } \\
\text { - Media literacy }\end{array}$ & $\begin{array}{l}\text { - Individual traits (age, } \\
\text { race, gender, cultural } \\
\text { background, cognitive } \\
\text { and physical abilities, } \\
\text { social skills) } \\
\text { - Media use } \\
\text { - Peer and parent influ- } \\
\text { ences } \\
\text { - Mass media, the educa- } \\
\text { tion system and the } \\
\text { health system }\end{array}$ & $\begin{array}{l}\text { - Health behavior } \\
\text { - Health costs } \\
\text { - Health service use }\end{array}$ \\
\hline$\overline{11}$ & $\begin{array}{l}\text { Freedman } \\
\text { et al. (2009) }\end{array}$ & $\begin{array}{l}\text { - Conceptual foundations } \\
\text { - Critical skills } \\
\text { - Civic orientation }\end{array}$ & $\begin{array}{l}\text { Social, environmental } \\
\text { and political forces }\end{array}$ & $\begin{array}{l}\text { - Resolve some of society's more } \\
\text { pressing health issues } \\
\text { - Alleviate social injustices }\end{array}$ \\
\hline 12 & $\begin{array}{l}\text { Von Wagner } \\
\text { et al. (2009) }\end{array}$ & $\begin{array}{l}\text { - Ability to rely on literacy } \\
\text { and numeracy skills when } \\
\text { they are required to solve } \\
\text { problems }\end{array}$ & $\begin{array}{l}\text { - Epidemiological or } \\
\text { structural determinants } \\
\text { - Individual influences } \\
\text { - Reading and arithmetic } \\
\text { skills } \\
\text { - External influences }\end{array}$ & $\begin{array}{l}\text { - Access and use of healthcare } \\
\text { - Patient-provider interaction } \\
\text { - Management of health and illness }\end{array}$ \\
\hline
\end{tabular}

For the antecedents, most authors refer to demographic, psychosocial and cultural factors, as well as to more proximal factors such as general literacy, individual characteristics and prior experience with illness and the healthcare system. Among the demographic and social factors which impact on health literacy one notes socioeconomic status, occupation, employment, income, social support, culture and language (Paasche-Orlow \& Wolf, 2007), environmental and political forces (Freedman et al., 2009) and media use (Manganello, 2008). In addition, peer and parental influences may impact on the health literacy of adolescents. In terms of personal characteristics, health literacy is predicted by age, race, gender and cultural background (Manganello, 
2008); as well as by competences such as vision, hearing, verbal ability, memory and reasoning (Paasche-Orlow \& Wolf, 2007), physical abilities and social skills (Manganello, 2008), and meta-cognitive skills associated with reading, comprehension, and numeracy (Manganello, 2008; Speros, 2005; UNESCO, 2005). The latter refers to the level of overall literacy, defined as the capacity to use printed and written information to function in society, achieve one's goals and develop one's knowledge and potential. Finally, Nutbeam (Nutbeam, 2000a) points out that health literacy is also a result of health promotion actions such as education, social mobilization and advocacy.

In terms of the consequences, a number of researchers pointed out that health literacy leads to improved self-reported health status, lower healthcare costs, increased health knowledge, shorter hospitalization and less frequent use of healthcare services (Mancuso, 2008; Manganello, 2008; Nielsen-Bohlman et al., 2004; Speros, 2005). According to Baker (Baker, 2006), these better health outcomes are caused by the acquisition of new knowledge, more positive attitudes, greater self-efficacy and positive health behaviors associated with higher health literacy. Paashe-Orlow and Wolf (Paasche-Orlow \& Wolf, 2007) posit that health literacy influences three main factors which in turn have an impact on health outcomes: 1) navigation skills, selfefficacy and perceived barriers influence the access and utilization of healthcare; 2) knowledge, beliefs and participation in decision-making influence patient/provider interactions and 3) motivation, problem-solving, self-efficacy, and knowledge and skills influence self-care. The relationship of health literacy to health outcomes according to these authors must be conceived as a step function with a threshold effect, rather than in a simple linear fashion. People generally exist within a web of social relationships; and below a certain level of function, much of the day-to-day detail of chronic disease management often needs to be facilitated by others. While the interaction between health literacy and social support is likely to have complicated and subtle implications, the health impact of social effects has not been fully elucidated in the context of health literacy (S.-Y. D. Lee et al., 2004).

Nutbeam (Nutbeam, 2000a) distinguishes between individual and community or social benefits of health literacy. In terms of individual benefits, functional health literacy leads to an improved knowledge of risks and health services and compliance with prescribed actions; interactive health literacy to an improved capacity to act independently, an improved motivation and more self-confidence and critical health literacy to improved individual resilience to social and economic adversity. In terms of community and social benefits, functional health literacy increases the participation in population health programs; interactive health literacy enhances the capacity to influence social norms and interact with social groups; and critical health literacy improves community empowerment and enhances the capacity to act on social and economic determinants of health. Nutbeam's conceptual framework has been applied in case 
studies focusing on topics of diarrhea (R. Wang, 2000), self-management in diabetes (Levin-Zamir \& Peterburg, 2001) and health promoting schools (Leger, 2001).

Ratzan (Ratzan, 2001) links health literacy in the community to the concept of social capital, arguing that health literate people live longer and have stronger incentives to invest in developing their own and their children's knowledge and skills. Healthier populations tend to have higher labor market productivity contributing to, rather than withdrawing from, pension schemes. Similarly, healthier people use the health system less and, coupled with education and cognitive function, appropriately demand fewer health services.

\section{An integrated conceptual model of health literacy}

Whereas a number of conceptual models of health literacy have been presented in the literature, none of these can be regarded as sufficiently comprehensive to line up with the evolving health literacy definitions and with the competencies they imply (Protheroe et al., 2009). This is probably due to the fact that attempts to conceptualize health literacy have thus far failed to integrate the existing knowledge encompassing different perspectives on health literacy. Firstly, most of the existing conceptual models are not sufficiently grounded in theory in terms of the notions and concepts included. Secondly, very few models have integrated the components included in "medical" and "public health" literacy models. The only models which explicitly try to bridge the difference between both views are Nutbeam's (Nutbeam, 2000a) and Manganello's (Manganello, 2008), whose dimension of functional literacy corresponds with the cognitive skills of medical health literacy. Thirdly, while acknowledging that health literacy entails different dimensions, the majority of the existing models are rather static and do not explicitly account for the fact that health literacy is also a process, which involves the consecutive steps of accessing, understanding, processing and communicating information. Fourthly, while most conceptual models identify the factors that influence health literacy and mention its impact on health service use, health costs and health outcomes, the pathways linking health literacy to its antecedents and consequences are not very clear. Researchers could link conceptual models of health literacy more explicitly to established health promotion theories and models (Protheroe et al., 2009). Finally, very few conceptual models of health literacy have been empirically validated. To address these shortcomings, we propose an integrated model of health literacy which captures the main dimensions of the existing conceptual models reviewed above (Figure 2.1)

The model combines the qualities of a conceptual model outlining the main dimensions of health literacy (represented in the concentric oval shape in the middle of Figure 2.1 and of a logical model showing the proximal and distal factors which impact on health literacy, as well as the pathways linking health literacy to health outcomes. 
The core of the model shows the competencies related to the process of accessing, understanding, appraising and applying health-related information. According to the 'all inclusive' definition this process requires four types of competencies: 1) Access refers to the ability to seek, find and obtain health information; 2) Understand refers to the ability to comprehend the health information that is accessed; 3) Appraise describes the ability to interpret, filter, judge and evaluate the health information that has been accessed and 4) Apply refers to the ability to communicate and use the information to make a decision to maintain and improve health. Each of these competences represents a crucial dimension of health literacy, requires specific cognitive qualities and depends on the quality of the information provided (Magasi, Durkin, Wolf, \& Deutsch, 2009): obtaining and accessing health information depends on understanding, timing and trustworthiness; understanding the information depends on expectations, perceived utility, individualization of outcomes and interpretation of causalities; processing and appraisal of the information depends on the complexity, jargon and partial understandings of the information; and effective communication depends on comprehension. The competencies also incorporate the levels of functional, interactive and critical health literacy as proposed by Nutbeam (Nutbeam, 2000a).

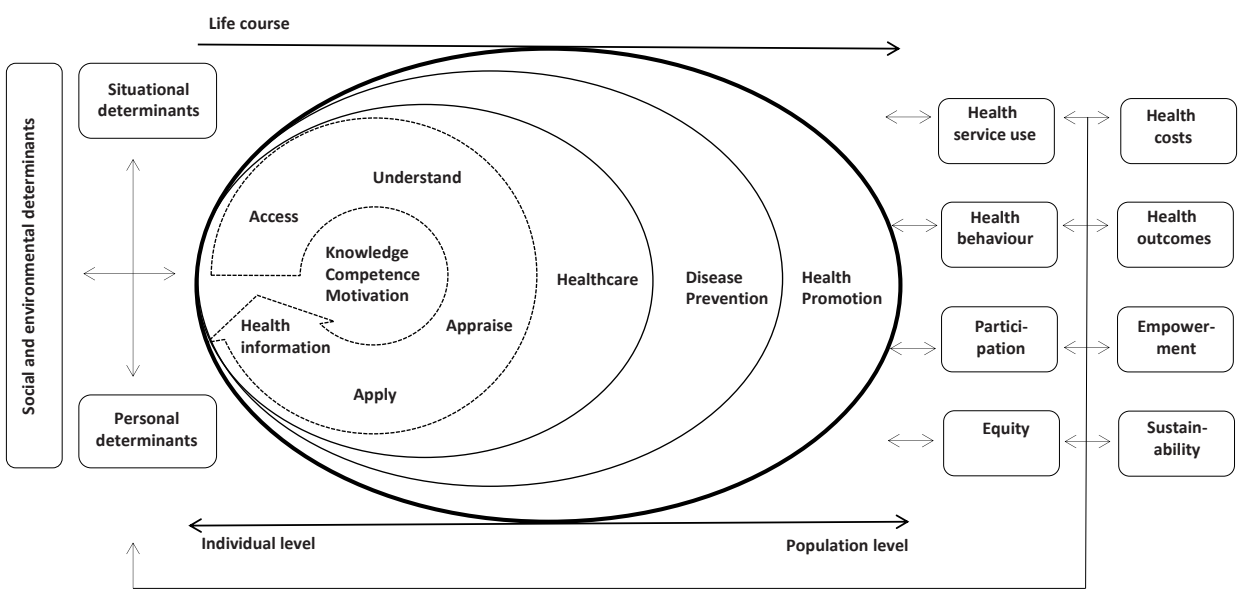

Figure 2.1 Integrated model of health literacy (own source)

This process generates knowledge and skills which enable a person to navigate three domains of the health continuum: being ill or as a patient in the healthcare setting, as a person at risk of disease in the disease prevention system and as a citizen in relation to the health promotion efforts in the community, the work place, the educational system, the political arena and the market place. Going through the steps of the health literacy process in each of these three domains equips people to take control over their health by applying their general literacy and numerical skills as well as their spe- 
cific health literacy skills to acquire the necessary information, understanding this information, critically analyzing and appraising it and acting independently to engage in actions overcoming personal, structural, social and economic barriers to health. As contextual demands change over time and the capacity to navigate the health system depends on cognitive and psychosocial development as well as on previous and current experiences, the skills and competencies of health literacy develop during the life course and are linked to life-long learning.

The frameworks associated with the three domains represent a progression from an individual towards a population perspective. As such, the model integrates the "medical" conceptualization of health literacy with the broader "public health" perspective. Placing greater emphasis on heath literacy outside of healthcare settings has the potential to impact on preventative health and reduce pressures on health systems. The combination of the four dimensions referring to health information processing with the three levels of domains yields a matrix with twelve dimensions of health literacy as illustrated in Table 2.4 .

- Four dimensions of health literacy in the domain of healthcare, i.e., the ability to access information on medical or clinical issues, to understand medical information, to interpret and evaluate medical information and to make informed decisions on medical issues and comply with medical advice.

- Four dimensions of health literacy in the domain of disease prevention, notably the ability to access information on risk factors for health, to understand information on risk factors and derive meaning, to interpret and evaluate information on risk factors and to make informed decisions on risk factors for health.

- Four dimensions in the domain of health promotion, notably the ability to regularly update oneself on determinants of health in the social and physical environment, to comprehend information on determinants of health in the social and physical environment and derive meaning, to interpret and evaluate information on determinants, of health in the social and physical environment and the ability to make informed decisions on health determinants in the social and physical environment.

Health literacy is in our understanding regarded an asset for improving people's empowerment within the domains of healthcare, disease prevention and health promotion. In addition to the components of health literacy proper, the model in Figure 2.1 also shows the main antecedents and consequences of health literacy. Among the factors which impact on health literacy, a distinction is made between more distal factors, including societal and environmental determinants (e.g. demographic situation, culture, language, political forces, societal systems), and proximal factors, which 
are more concerned with personal determinants (e.g. age, gender, race, socioeconomic status, education, occupation, employment, income, literacy) and situational determinants (e.g. social support, family and peer influences, media use and physical environment). Health literacy is strongly associated with educational attainment (Manganello, 2008) as well as with overall literacy (Zarcadoolas et al., 2003, 2005, 2012). Fundamental literacy affects a wide range of cognitive, behavioral and societal skills and abilities. It should be distinguished from other specific literacy, such as science literacy (i.e., the ability to comprehend technical complexity, understanding of common technology and an understanding that scientific uncertainty is to be expected), cultural literacy (i.e. recognizing and using collective beliefs, customs, worldviews, and social identity relationships) and civic literacy (e.g. knowledge about sources of information and about agendas and how to interpret them, enabling citizens to engage in dialogue and decision-making). According to Mancuso (Mancuso, 2009), an individual must have certain skills and abilities to obtain competence in health literacy and identifies six dimensions that are considered as necessary antecedents of health literacy, namely operational, interactive, autonomous, informational, contextual and cultural competence.

Table 2.4 The matrix with four dimensions of health literacy applied to three health domains

\begin{tabular}{|c|c|c|c|c|}
\hline & $\begin{array}{l}\text { Access/obtain } \\
\text { information rele- } \\
\text { vant to health }\end{array}$ & $\begin{array}{l}\text { Understand infor- } \\
\text { mation relevant to } \\
\text { health }\end{array}$ & $\begin{array}{l}\text { Process/appraise } \\
\text { information rele- } \\
\text { vant to health }\end{array}$ & $\begin{array}{l}\text { Apply/use infor- } \\
\text { mation relevant to } \\
\text { health }\end{array}$ \\
\hline Healthcare & $\begin{array}{l}\text { Ability to access } \\
\text { information on } \\
\text { medical or clinical } \\
\text { issues }\end{array}$ & $\begin{array}{l}\text { Ability to under- } \\
\text { stand medical } \\
\text { information and } \\
\text { derive meaning } \\
\end{array}$ & $\begin{array}{l}\text { Ability to interpret } \\
\text { and evaluate medi- } \\
\text { cal information }\end{array}$ & $\begin{array}{l}\text { Ability to make } \\
\text { informed decisions } \\
\text { on medical issues }\end{array}$ \\
\hline Disease prevention & $\begin{array}{l}\text { Ability to access } \\
\text { information on risk } \\
\text { factors for health }\end{array}$ & $\begin{array}{l}\text { Ability to under- } \\
\text { stand information } \\
\text { on risk factors and } \\
\text { derive meaning }\end{array}$ & $\begin{array}{l}\text { Ability to interpret } \\
\text { and evaluate in- } \\
\text { formation on risk } \\
\text { factors for health }\end{array}$ & $\begin{array}{l}\text { Ability to make } \\
\text { informed decisions } \\
\text { on risk factors for } \\
\text { health }\end{array}$ \\
\hline Health promotion & $\begin{array}{l}\text { Ability to update } \\
\text { oneself on deter- } \\
\text { minants of health in } \\
\text { the social and } \\
\text { physical environ- } \\
\text { ment }\end{array}$ & $\begin{array}{l}\text { Ability to under- } \\
\text { stand information } \\
\text { on determinants of } \\
\text { health in the social } \\
\text { and physical envi- } \\
\text { ronment and derive } \\
\text { meaning }\end{array}$ & $\begin{array}{l}\text { Ability to interpret } \\
\text { and evaluate in- } \\
\text { formation on } \\
\text { health determi- } \\
\text { nants in the social } \\
\text { and physical envi- } \\
\text { ronment }\end{array}$ & $\begin{array}{l}\text { Ability to make } \\
\text { informed decisions } \\
\text { on health determi- } \\
\text { nants in the social } \\
\text { and physical envi- } \\
\text { ronment }\end{array}$ \\
\hline
\end{tabular}

Health literacy in turn influences health behavior and the use of health services, and thereby will also impact on health outcomes and on the health costs in society. At an individual level, ineffective communication due to poor health literacy will result in errors, poor quality, and risks to patient safety of the healthcare services (Schyve, 2007). At a population level, health literate persons are able to participate in the ongoing public and private dialogues about health, medicine, scientific knowledge and cul- 
tural beliefs. Thus, the benefits of health literacy impact the full range of life's activities - home, work, society and culture (Zarcadoolas et al., 2003, 2005, 2012). Advancing health literacy will progressively allow for greater autonomy and personal empowerment and the process of health literacy can be seen as a part of an individual's development towards improved quality of life. In the population, it may also lead to more equity and sustainability of changes in public health. Consequently, low health literacy can be addressed by educating persons to become more resourceful (e.g. increasing their personal health literacy) and by making the task or situation less demanding, (e.g. improving the "readability of the system").

\section{Discussion}

In this article we have presented a working definition of health literacy which represents the essence of the definitions of this concept as given in the literature. Furthermore a new conceptual model has been developed as a result of the review of existing health literacy concepts. While the literature indicates that health literacy refers to the competences of people to meet the complex demands of health in modern society (Kickbusch \& Maag, 2008; McQueen et al., 2007) the exact nature of these competences is still debated. One perspective is that they refer to a series of individual cognitive skills and abilities applied in a medical context; the other perspective sees a broader range of competencies applied in the social realm. The first is referred to as "medical health literacy" (Peerson \& Saunders, 2009), "patient health literacy" (Ishikawa \& Yano, 2008), or "clinical health literacy" (Pleasant \& Kuruvilla, 2008); the second as "public health literacy" (Freedman et al., 2009). Nutbeam (Nutbeam, 2008) refers to the opposing medical and public health views on health literacy as respectively a "clinical risk" and a "personal asset" approach and points out that they are rooted in the different traditions of clinical care, and adult learning and health promotion, respectively. As both perspectives are important and useful to enable a better understanding of health communication processes in clinical and community settings, any definition of health literacy needs to integrate both views. The proposed 'all inclusive' definition is adaptable and includes the public health perspective as well as the individual perspective.

While originating from the study of the reading and numerical skills that are necessary to function adequately in the healthcare environment, the concept of health literacy has expanded in meaning to include information-seeking, decision-making, problem-solving, critical thinking, and communication, along with a multitude of social, personal and cognitive skills that are imperative to function in the health-system (Baker, 2006; Nutbeam, 2008; Protheroe et al., 2009). It has now diffused into the 
realm of culture, context, and language (Baker, 2006; Nutbeam, 2008; Protheroe et al., 2009). Although some authors have argued that health literacy is merely "new wine in old bottles" and is basically the repackaging of concepts central to the ideological theory and practice of health promotion (Tones, 2002b), enhancing health literacy is increasingly recognized as a public health goal and a determinant of health. As new health literacy frameworks have emerged to clarify the deeper meaning of health literacy, its contribution to health, and the social, environmental and cultural factors that influence health literacy skills in a variety of populations, there is a need for an integration of diverging definitions, conceptual frameworks and models of health literacy.

The conceptual framework presented in this paper provides this integration in the form of a comprehensive model. Based on a systematic review of existing definitions and conceptualizations of health literacy, it combines the qualities of a conceptual model outlining the most comprehensive dimensions of health literacy, and of a logical model, showing the proximal and distal factors which impact on health literacy as well as the pathways linking health literacy to health outcomes. Specifically, the model identifies twelve dimensions of health literacy, referring to the competencies related to accessing, understanding, appraising and applying health information in the domains of healthcare, disease prevention and health promotion, respectively.

By integrating existing definitions and conceptualizations of health literacy into an encompassing model outlining the main dimensions of health literacy as well as its determinants and the pathways to health outcomes, this model has a heuristic value in its own right. More importantly, however, it can also support the practice of healthcare, disease prevention and health promotion by serving as a conceptual basis to develop health literacy enhancing interventions. Moreover, it can contribute to the empirical work on health literacy by serving as a basis for the development of measurement tools. As currently available tools to measure health literacy do not capture all aspects of the concept as discussed in the literature, there is a need to develop new tools to assess health literacy, reflecting health literacy definitions and accompanying conceptual models for public health. By following a concept validation approach, scales can be developed to assess the dimensions outlined in the conceptual model presented in this paper. This will not only produce a comprehensive measure of health literacy, reflecting the state of the art of the field and applicable for social research and in public health practice, but also serve to validate the conceptual model and thus contribute to the understanding of health literacy. 


\section{Authors' contributions}

Background: KS, SVDB, JF, GD. Methodology: KS, SVDB, JF. Results: KS and JF. Discussion: KS, SVDB, HB, JF, GD, ZS and JP. Conclusion: KS, SVDB, JF and GD. All authors read and approved the final manuscript.

\section{Acknowledgements}

The authors thank all partners in the HLS-EU consortium for contributing to the development of the conceptual model and the content of this article. 


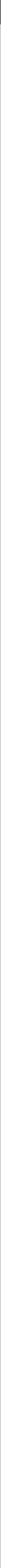


Say not, 'I have found the truth',

but rather, I have found a truth.

Kahlil Gibran 


\section{CHAPTER 3}

\section{The European health literacy glossary}

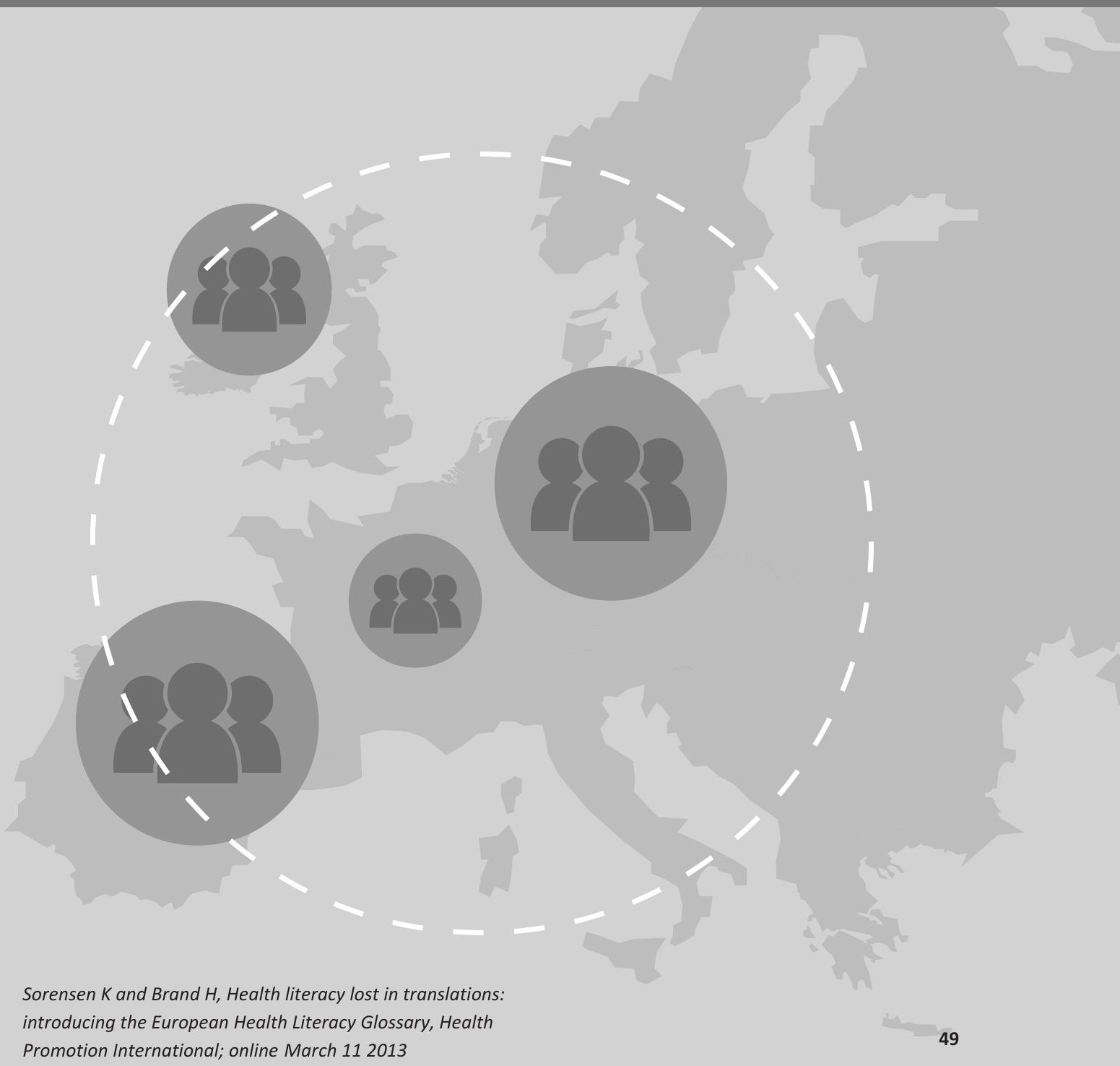




\begin{abstract}
Health literacy has gained momentum in the Western world. Yet, in Europe, the concept of health literacy is only marginally integrated in research, policy and practice. The current paper presents how translation may act as an influential factor with regard to integration of the health literacy notion in Europe. This study has compared five data sources that provide translations of health literacy: The European Union's Health Strategy; the World Health Organisation's Health 2020 strategy, the translations applied in the European Health Literacy project, national health expert opinions and Google Translate. The comparison integrated Peter Fawcett's translation techniques as a framework for linguistic analysis. The results showed a total of 29 translations: 22 from the European Union Health Strategy; 3 from Health 2020, 6 from the HLS-EU survey; 17 from experts; 25 from Google Translate. Some countries are consistent in translations of health literacy while other countries diverge. Health literacy is not yet mainstreamed and the translations are primarily driven by a latent polarized discourse of the concept of literacy. The study showed that translations, in general, reveal enriched insights in the legitimacy of health literacy as one notion and provides the European Health Literacy Glossary that can inform health professionals, academia and decision-makers to further advance health literacy across Europe and in the rest of the world.
\end{abstract}




\section{Introduction}

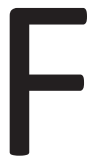

orty years after its introduction in the educational field (Simonds, 1974) the concept of health literacy has gained momentum in health research, policy and practice (Nutbeam, 1998, 2000b; Parker, Baker, Williams, \& Nurss, 1995; Parker

\& Ratzan, 2010; Rudd, Moeykens, \& Colton, 1999; Wills, 2009). Health literacy is closely linked to literacy and entails the knowledge, motivation and competency to access, understand, appraise and apply health information to form judgment and take decisions in terms of healthcare, disease prevention, and health promotion in terms of maintaining and promoting quality of life throughout the course of life (Sorensen, Van den Broucke, et al., 2012). "It goes beyond the individual obtaining of information. Health literacy emerges when the expectations, preferences and skills of individuals seeking health information and services meet the expectations, preferences and skills of those providing information and services. Health literacy arises from a convergence of education, health services and social and cultural factors; and brings together research and practice from diverse fields" (p. 2) (Nielsen-Bohlman et al., 2004). As such "Health literacy is a shared function of social and individual factors" (p. 4) (NielsenBohlman et al., 2004) and it relates to "the context of everyday life - at home, in the community, at the workplace, in the health-care system, in the market place and in the political arena. It is a critical empowerment strategy to increase people's control over their health, their ability to seek out information, and their ability to take responsibility." (Kickbusch et al., 2005). However, people with low levels of health literacy report poorer health status and experience poorer health outcomes compared to those with good health literacy (Berkman, Sheridan, Donahue, Halpern, \& Crotty, 2011) and, in response, policies have been developed to promote individual and public health literacy such as the American National Action Plan to Improve Health Literacy (U.S. Department of Health and Human Services., 2010), the Health Strategy 2008-2013 (European Commission, 2007) and Health 2020 (World Health Organisation's European Office, 2012).

Whereas health literacy research has been conducted for decades in native English-speaking countries such as Australia, Canada, and the United States (Adams et al., 2009; Buchbinder et al., 2011; Paasche-orlow \& Wolf, 2007; Rootman \& Gordon-ElBihbety, 2008) the health literacy field in Europe is still in its infancy. Though a few national studies exist (Fransen, Van Schaik, Twickler, \& Essink-Bot, 2011; J. Wang, Schmid, \& Thombs, 2012), in addition to the first, recently conducted European comparative study of health literacy (HLS-EU Consortium, 2012a), the field of health literacy in many European countries remains unexplored.

Grounded in the observation made by the investigators that the translations used in the European Commission's Health Strategy 2008-2013 reveals a lack of consistency 
in content, which allow for different interpretation of the term; this paper presents how translation may act as an influential factor with regard to health literacy valorisation in Europe. Translation can be defined as the process of abstracting the meaning of a text from its original form and reproduce that meaning with the very different forms of a second language, also called a receptor language (Larson, 1998). It is applied by studying the lexicon, grammatical structure, communication situation, cultural context of the source language and analysing it in order to determine its meaning and then reconstructing this same meaning using the lexicon and grammatical structure which are appropriate in the receptor language and its cultural context (Larson, 1998; Pym, 2010). However, the Sanskrit and Hindi terms for the word translation (anuvad) means 'repeating' or 'saying later', indicating that the difference between source and receptor texts is located in time, not in space. "Translation might then be seen as a constant process of updating and elaborating rather than some kind of physical movement across cultures" ((Pym, 2010); chapter $1 ; 1.1)$. Hence, bearing in mind that discourses differ within translational theory, this study aims to identify existing translations of health literacy in the European context and to explore the linguistic characteristics by comparing and clarifying similarities and differences in terms of content and consistency. In addition, the collected translations will be compiled to a European Health Literacy Glossary which can contribute support and secure a more profound and transparent basis for health literacy research, policy development and application throughout the European region.

\section{Methods}

The linguistic analysis in the current study involved a two-step procedure including an initial source analysis of health literacy in English followed by a comparative receptor analysis of European health literacy translations to explore differences and similarities in terms of a specified set of translation criteria derived from Fawcett (Peter Fawcett, 1997). The data was collected from several sources as explained in the following. In order to convey the source analysis of the original term in English, it was decided to consult Encyclopaedia Britannica (Encyclopaedia Britannica, 2011), as well as review the thesaurus in the digital versions of the New Oxford American Dictionary (NOAD) (The New Oxford American Dictionary, 2008) and the British Merriam-Webster Dictionary (BMWD) (Merriam-Webster, 2011). The two dictionaries were chosen to ensure that both an American and a British perspective were applied. As the data search for the source analysis revealed no result for the notion of 'health literacy' in either of the tree sources, the words 'health' and 'literacy' were explored separately in their own rights as an attempt to understand the combined notion of 'health literacy'. 
In terms of the receptor analysis, five data sources were identified that included various health literacy translations appropriate for the study. The five sources consisted of two policy-based, two research-based, and one machine-based source. Hence, the translations, which are included in the study, are derived from the European Commission's Health strategy 2007-2013: Together for Health (European Commission, 2007), the World Health Organisation's European strategy Health 2020 (World Health Organisation's European Office, 2012), the European Health Literacy Survey (HLS-EU) (HLS-EU Consortium, 2012a), proposals from health experts, and machine-translations from Google Translate (Google, 2012). These sources are presented in detail in the following:

1. Translations from the European Commission's health strategy: The Health Strategy was translated in 2007 upon its release, and the specific translations of health literacy were all included in this study. The Directorate General of Translation was responsible for the translations; their general output concerning translation of, e.g. proposed laws, policy papers, and consultation documents, reached 2.11 million pages in 2011 (DG Translation, 2012).

2. Translations from Health $\mathbf{2 0 2 0}$ by the World Health Organisation: The translations of health literacy included in Health 2020 were extracted from the official translations of the strategy made available by the World Health Organisation's working papers prior to the finalization of the strategy. The translations included in this study were traced in the document from the Regional Director called: The new European policy for health Health 2020: Vision, values, main directions and approaches (World Health Organisation's European Office, 2011).

3. Translations from the HLS-EU survey by the HLS-EU Consortium: The translation procedure applied in the HLS-EU survey entailed two independent translations made by professional translators from English to the receptor language and a subsequent panel discussion among the translators and health (literacy) professionals with the aim of reaching ultimate consensus for one version (HLS-EU Consortium, 2012a).

4. Translations recommended by health (literacy) professionals: An additional source of data included translations provided by health professionals acting as key informants to this study. They were identified through Health Literacy Europe, a network for health literacy interested professionals, or through snow-ball recruitment based on recommendations 
from professionals taking part in the study. The inclusion criteria entailed being a native speaker of a specific European language, having an insight in health, and preferably health literacy related to policy, research or practice. The recruitment took place in October and November 2011 and a follow-up was conducted in the beginning of 2012 . The health professionals answered the following questions: 1 . Introduced to the translation of health literacy in the European Health Strategy, do you agree with the translation? 2. If not, what would you suggest? 3. Why? 4. Is there a 'common' understanding of which terminology to use in your language?

5. What term would it be? For countries that were not members of the European Union, the key informant was asked, in general, how to translate health literacy into their own language.

5. Translations provided by Google Translate: As a final source, Google Translate was selected as a commonly used option for providing quick translations for professionals and lay-people. The translations for this study were traced in February 2012. Google Translate is a free translation service that provides instant translations for 58 languages by using a technique called 'statistical machine translation'. When a translation is generated, the programme scans for patterns in hundreds of millions of documents to help decide on the best translation. Since the translations are provided by machines, the quality of translations varies as they depend on the availability of human-translated documents that Google Translate can analyses in a specific language (Google, 2012).

The data collection for the receptor analysis resulted in 22 translations obtained from the EU Health Strategy; 3 from the Health 2020 strategy; 6 from the HLS-EU Survey; 17 from health professionals in countries across Europe and 26 translations from Google Translate. In total, the data collection represented translation of health literacy into 29 European languages as outlined in Table 3.1.

The two-step analysis approach focusing on source, as well as receptor, languages was selected to determine how similarities and differences in the various translations of the source language could be explained. In turn, Fawcett's criteria were employed as analytical framework to ensure a firm and coherent analysis of the considerable amount of receptor translations included. The criteria referred to eight specific translation techniques outlined by Fawcett (Peter Fawcett, 1997) that included the following.

1. Borrowing: means taking words straight into another language.

2. Calque: refers to a literal translation at phrase level. 
3. Literal translation: means to translate exactly, word for word, what is said.

4. Transposition: describes movement of words within a sentence to match grammatical needs when translating from source to receptor text.

5. Modulation: involves using a phrase that is different in the source language from the receptor language to convey the same idea.

6. Reformulation: requires expressing something in a completely different way.

7. Adaptation: explains that something specific to the source language culture is expressed in a totally different way that is familiar or appropriate from the receptor language culture.

8. Compensation: refers in a general term to the case when something cannot be translated from source to target language; the meaning that is lost in the immediate translations is being expressed elsewhere to make sense of what could not be translated in the first place.

While applying Fawcett's translational techniques is a novel step in the realm of health research, his work is recognized within the translation field (Emery, 2005; Ulrych, 2002). Yet, recognizing that the art and science of translation encounter a wide range of translational theories (Pym, 2010) combined with the fact that the authors have a background in public health, the study inevitably faced limitations in terms of providing an in-depth linguistic analysis of health literacy. Therefore, future work should explore the linguistic aspects of health literacy more profoundly in order to strengthen the knowledge base concerning health literacy translations.

Table 3.1: The European Health Literacy Glossary

\begin{tabular}{|c|c|c|c|c|c|c|}
\hline \# & Language & $\begin{array}{l}\text { EU Health } \\
\text { Stratgy }\end{array}$ & WHO 2020 & HLS-EU Survey & $\begin{array}{l}\text { Key health in- } \\
\text { formant }\end{array}$ & Google Translate \\
\hline 1 & Albanian & - & - & - & $\begin{array}{l}\text { Kompetencat } \\
\text { shëndetësore }\end{array}$ & $\begin{array}{l}\text { Analfabetizmi } \\
\text { shëndetësor }\end{array}$ \\
\hline 2 & Bulgarian & $\begin{array}{l}\text { здравна } \\
\text { грамотност }\end{array}$ & - & $\begin{array}{l}\text { здравна } \\
\text { грамотност }\end{array}$ & - & $\begin{array}{l}\text { здравна } \\
\text { грамотност }\end{array}$ \\
\hline 3 & Czech & $\begin{array}{l}\text { Zdravotní } \\
\text { gramotnosti }\end{array}$ & - & - & - & $\begin{array}{l}\text { zdravotní } \\
\text { gramotnosti }\end{array}$ \\
\hline 4 & Croatian & - & - & - & $\begin{array}{l}\text { Zdravstvena } \\
\text { pismenost }\end{array}$ & $\begin{array}{l}\text { Zdravstvene } \\
\text { pismenosti }\end{array}$ \\
\hline 5 & Danish & $\begin{array}{l}\text { Sundheds- } \\
\text { kompetence }\end{array}$ & - & - & $\begin{array}{l}\text { Sundheds- } \\
\text { kompetence }\end{array}$ & $\begin{array}{l}\text { Sundheds- } \\
\text { kompetence }\end{array}$ \\
\hline 6 & Dutch & $\begin{array}{l}\text { Gezondheids- } \\
\text { geletterdheid }\end{array}$ & - & $\begin{array}{l}\text { Gezondheids- } \\
\text { kompetenties }\end{array}$ & $\begin{array}{l}\text { Gezondheidsvaar- } \\
\text { heidsvaar- } \\
\text { digheden }\end{array}$ & - \\
\hline
\end{tabular}


Table 3.1: The European Health Literacy Glossary (continued)

\begin{tabular}{|c|c|c|c|c|c|c|}
\hline 7 & German & $\begin{array}{l}\text { Gesundheits- } \\
\text { kompetenz }\end{array}$ & $\begin{array}{l}\text { Gesundheits- } \\
\text { kompetenz }\end{array}$ & $\begin{array}{l}\text { Gesundheitscom- } \\
\text { petenz }\end{array}$ & $\begin{array}{l}\text { Gesundheitskom- } \\
\text { petenz }\end{array}$ & $\begin{array}{l}\text { Gesund- } \\
\text { heitskompetenz }\end{array}$ \\
\hline 8 & Estonian & $\begin{array}{l}\text { Tervishoiualase } \\
\text { harituse }\end{array}$ & - & - & - & $\begin{array}{l}\text { Tervisealase } \\
\text { kirjaoskuse }\end{array}$ \\
\hline 9 & English & Health literacy & - & Health literacy & Health literacy & Health literacy \\
\hline 10 & Finnish & $\begin{array}{l}\text { Terveyso- } \\
\text { saamiseen } \\
\text { liittyviä }\end{array}$ & - & - & $\begin{array}{l}\text { Terveyso- } \\
\text { saaminen }\end{array}$ & $\begin{array}{l}\text { Terveys lukutai- } \\
\text { to }\end{array}$ \\
\hline 11 & French & $\begin{array}{l}\text { Connaissances } \\
\text { en matière de } \\
\text { santé }\end{array}$ & $\begin{array}{l}\text { Connaissances } \\
\text { en matière de } \\
\text { santé }\end{array}$ & - & $\begin{array}{l}\text { Alphabetisme en } \\
\text { matière de santé } \\
\text { littéracie en } \\
\text { matière de santé }\end{array}$ & $\begin{array}{l}\text { Littératie en } \\
\text { santé }\end{array}$ \\
\hline 12 & Greek & 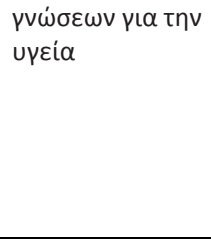 & - & 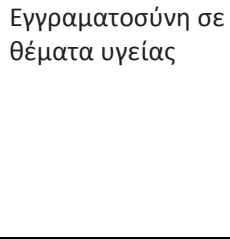 & 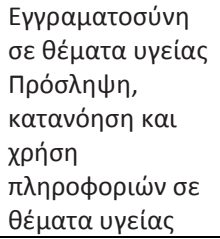 & 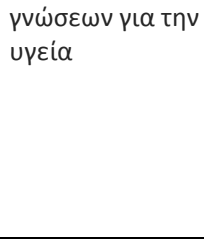 \\
\hline 13 & Hebrew & - & - & - & בריאותית אוריינות & אוריינות בריאות \\
\hline 14 & Hungarian & Egészségismeret & - & - & - & $\begin{array}{l}\text { Egészségügyi } \\
\text { ismeretek }\end{array}$ \\
\hline 15 & Italian & $\begin{array}{l}\text { Alfabetizzazione } \\
\text { sanitaria }\end{array}$ & - & - & $\begin{array}{l}\text { Alfabetizzazione } \\
\text { Sanitaria }\end{array}$ & - \\
\hline 16 & Lithuanian & $\begin{array}{l}\text { Sveikatos } \\
\text { raštinguma }\end{array}$ & - & - & $\begin{array}{l}\text { Sveikatos ras- } \\
\text { tingumas }\end{array}$ & $\begin{array}{l}\text { Sveikatos } \\
\text { raštingumas }\end{array}$ \\
\hline 17 & Latvian & $\begin{array}{l}\text { Veselības } \\
\text { izglītības jomā }\end{array}$ & - & - & - & Veselības mācība \\
\hline 18 & $\begin{array}{l}\text { Mace- } \\
\text { donian }\end{array}$ & - & - & - & - & $\begin{array}{l}\text { здравствена } \\
\text { писменост }\end{array}$ \\
\hline 19 & Maltese & 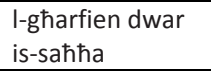 & - & - & - & Litteriżmu saћћa \\
\hline 20 & Norweigan & - & - & - & $\begin{array}{l}\text { Helsefremmende } \\
\text { allmendannelse / } \\
\text { helsekompetanse }\end{array}$ & $\begin{array}{l}\text { Helsekunn- } \\
\text { skapene }\end{array}$ \\
\hline 21 & Polish & $\begin{array}{l}\text { świadomości } \\
\text { zdrowotnej }\end{array}$ & - & $\begin{array}{l}\text { Kompetencje } \\
\text { zdrowotne }\end{array}$ & - & $\begin{array}{l}\text { Umiejętność } \\
\text { zdrowie }\end{array}$ \\
\hline 22 & Portuguese & $\begin{array}{l}\text { Literacia em } \\
\text { saúde }\end{array}$ & - & - & $\begin{array}{l}\text { Literacia em } \\
\text { saúde }\end{array}$ & $\begin{array}{l}\text { Educação em } \\
\text { saúde }\end{array}$ \\
\hline 23 & Romanian & $\begin{array}{l}\text { Cunoştinţele în } \\
\text { materie de } \\
\text { sănătate }\end{array}$ & - & - & $\begin{array}{l}\text { Abilitatea de a citi } \\
\text { si intelege notiuni } \\
\text { in materie de } \\
\text { sanatate }\end{array}$ & $\begin{array}{l}\text { Sănătate alfabet- } \\
\text { izare }\end{array}$ \\
\hline 24 & Russian & & $\begin{array}{l}\text { санитарной } \\
\text { грамотности }\end{array}$ & & & \\
\hline 25 & Serbian & - & - & - & $\begin{array}{l}\text { Zdravstvena } \\
\text { pismenost }\end{array}$ & $\begin{array}{l}\text { здравље } \\
\text { писменост }\end{array}$ \\
\hline 26 & Slovak & $\begin{array}{l}\text { Zdravotnej } \\
\text { gramotnosti }\end{array}$ & - & - & - & $\begin{array}{l}\text { Zdravotnej } \\
\text { gramotnosti }\end{array}$ \\
\hline 27 & Slovenian & $\begin{array}{l}\text { Zdravstveno } \\
\text { pismenost }\end{array}$ & - & - & - & $\begin{array}{l}\text { Zdravstveno } \\
\text { pismenost }\end{array}$ \\
\hline 28 & Spanish & $\begin{array}{l}\text { Instrucción } \\
\text { sanitaria }\end{array}$ & - & $\begin{array}{l}\text { Alfabetización en } \\
\text { salud }\end{array}$ & - & $\begin{array}{l}\text { Alfabetización } \\
\text { en salud }\end{array}$ \\
\hline 29 & Swedish & Hälsokunskap & - & - & Hälsoförmågå & Hälsokunskap \\
\hline
\end{tabular}




\section{Results}

The main purpose of this study was to examine European translations of health literacy as an influential factor for integration in European research, policy and practice on the basis of the data collection which yielded translations from 29 different languages. By applying Fawcett's translational techniques, the source term and the receptor language translations were scrutinized in a two-step analysis. It became evident that the European translations differ in several aspects as outlined in Table 3.1 and are reported in detail in the following.

\section{Results of the source analysis}

Since it became apparent that health literacy expressed as a single notion was not included in the Encyclopaedia Britannica nor in the comprehensive American or British dictionaries, the two words 'health' and 'literacy' were explored in their own rights to elude the underlying concepts.

\section{Health}

"'Health" in human beings was defined as the extent of an individual's continuing physical, emotional, mental and social ability to cope with his environment". This definition, according to Encyclopaedia Britannica, had its drawbacks and was but one of many definitions. It was described as the "extent of continuing physical, emotional, mental and social ability to cope with one's environment". In addition, according to Encyclopedia Britannica, good health is harder to define than bad health (which can be equated with presence of disease) because it must convey a more positive concept than mere absence of disease and there is a variable area between health and disease. For example, a person may be in good physical condition but have a cold or be mentally ill. Someone may appear healthy but have a serious condition (e.g. cancer) that is detectable only by physical examination or diagnostic tests or not even by these (Britannica Concise in BMWD). Similarly, the NOAD 'health' refers to the state of being free from illness or injury and, in BMWD, the noun is defined as the condition of being sound in body, mind, or spirit; especially the freedom from physical disease or pain or as 'the general condition of the body'.

\section{Literacy}

The Encyclopaedia Britannica explained 'literacy' as the "capacity to communicate using inscribed, printed, or electronic signs or symbols for representing language". Furthermore, it described how two major theories evolved. One presented literacy as an "autonomous", independent skill that proceeds 
along a predictable evolutionary path; the other described literacy as an "ideological" phenomenon that varies widely and unpredictably according to its social setting. Along similar veins, NOAD described how "literacy" could be understood as the ability to read and write but also as having competence or knowledge in a specified area. In addition, the BMWD defined "literacy" as the quality or state of being literate. One can thus be educated or cultured or have knowledge or competence such as, for example, being computer-literate or politically literate. Accordingly, being "literate" referred to one having or displaying advanced knowledge or education.

The fact that "health literacy" as a single notion was not included in the Encyclopaedia Britannica nor in estimated American and British dictionaries such as NOAD and BMWD suggests that "health literacy" is not considered part of mainstream English language. In contrast, both the words "health" and "literacy" were included. Whereas there was, in general, a broad consistency in the understanding of 'health', the explanations concerning the meaning of "literacy" were clearly polarized. One perspective focused on functional aspects by understanding "literacy" as, literally, the ability to read and write; the second perspective focused on having knowledge or competence, thus displaying advanced education.

\section{Results of the receptor analysis}

By comparison of translations within languages and between languages across sources, it was made evident by the application of Fawcett's translational techniques that translations vary in different aspects. The first comparison assessed if the word is borrowed and used directly in its English form. Though it cannot be extracted directly from the translations in Table 3.1, it was indirectly indicated in the key informant assessment that borrowing often took place by using and integrating the original term in English directly into the receptor language in many countries.

Concerning calque, where words are literally translated from one language to another, it appeared that the European Commission's Health Strategy, in particular, encompassed translations focusing on the functional aspects of literacy similarly to the explanation identified in the source analysis. Essentially, this aspect could be identified across all five sources, e.g. in Dutch where "health literacy" was translated as "gezondheidsgeletterdheid"; in French as "alphabetisme en matière de santé"; in Italian as "alfabetizzazione sanitaria" and in Spanish as "alfabetización en salud".

Transposition involves the movement of words within a sentence to match grammatical needs, and this aspect can be traced in the translations in several languages. Instead of requiring two words, it is reduced to one, thus combining "health" and "literacy" as in Swedish: "hälsoförmågå". Sometimes the order is changed as in Spanish: "instrucción sanitaria". In other occasions, three or more words are needed to explain 
the meaning of "health literacy" such as is seen in the Greek translation of the term

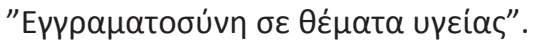

Modulation entails the use of a phrase which differs in the source language from the receptor language to convey the same idea. In this study, modulation is recorded in several languages where other words are chosen for the word "literacy" such as, for example, "awareness", "competence", "skills" and "knowledge". It is particularly apparent in languages in which the word "literacy" seems to not exist and, therefore, no direct translation is possible. Notably, coherent choices can be identified among several languages such as in German: "Gesundheitskompetenz"; in Danish: "sundhedskompetence"; and in Norweigan: "helsekompe-tanse".

The case of reformulation requires expressing something in a completely different way. Due to the analytical focus being only on the term "health literacy" and not on the word and its context, this analysis does not generate any examples of reformulation since all of the translations displayed mirror direct translations of health literacy in one way or another.

Notably, it could be concluded that it was out of the scope of this study to examine if the techniques concerning adaptation and compensation were applied in terms of translations in the current study. Adaptation occurs when a translation expresses something specific to the source language culture and is applied in a totally different way, either familiar or appropriate from the receptor language culture. Compensation refers to the case when something cannot be translated from source to target language; hence, the meaning that is lost in the immediate translations is being expressed somewhere else to make sense of what could not be translated in the first place. The reason was, as with reformulation, that the present analysis focused only on the health literacy word thus, it does not encounter the broader textual context.

In addition to the analysis applying Fawcett's techniques, streamlining and consensus forming within certain languages across all the five sources could be detected in a few cases as, for example, in the Danish translations (sundhedskompetence) and the Lithuanian translations (sveikatos rastingumas). In contrast, full proliferation was apparent in the Dutch case only where three different sources offered three different translations: 'gezondheidsgeletterdheid', 'gezondheidskompetenties' and 'gezondheidsvaardigheden'. The remaining sources did not offer any Dutch translations.

In summary, the findings of the receptor analysis revealed that differentiation was clearly apparent across the majority of translations with reference to aspects illuminated by Fawcett's criteria. The study made it evident that solutions divert for translations within a language as well as in comparison with different languages. Polarization was especially transparent with reference to the interpretation of the word 'literacy' as it displayed both as a functional literacy and as a critical competency. 
Similarly, the application of health literacy translations in research, policy and practice has been commonly used in other parts of the world, for example, in the United States for English/Spanish (Parker et al., 1995) and in Canada for English/French (Zanchetta \& Poureslami, 2006) as well as in cross-national work such as the International Adult Literacy Survey (IALS) (Kirsch, 2001). However, publications focusing on specific reflections concerning translation processes or application choices made with reference to health literacy are scarce. In contrast, this study proposes a European Health Literacy Glossary which provides new insights to the variety and range of translations available with reference to the European context alone. The findings indicate that the choice of health literacy inevitably highlights a certain direction in the way the notion of health literacy could be understood, interpreted and applied in the receptor countries. The data collection is extracted from policy, research and practice; hence, reflecting a wide spectrum of sources, and data is analyzed according to translational criteria rooted in linguistic theory. However, several limitations should be noted. Whereas the source analysis focused primarily on mainstream sources such as the encyclopedia and dictionaries, the lexicon of the health literacy could, preferably, have included sources reporting on the academic health literacy discourses. The focus on health literacy as a single term was not optimal concerning a few criteria in the analytical framework where emphasis referred to a broader textual and contextual analysis of the sources. Finally, although 29 languages were represented in the European Health Literacy Glossary, several languages still remain to be included. On the whole, the results, nevertheless, suggest that the choice of translations play a critical role in the application of health literacy in research, policy and practice in Europe.

\section{Discussion}

The health literacy field in Europe is in its infancy and a reason may be that the process of translation from English to another European language has implicitly become a barrier to its wider diffusion in the European context. In this study, translations were identified, compared and analysed according to Fawcett's linguistic criteria. The compilation of translations formed the basis for a new European Health Literacy Glossary which can support further implementation and promotion of health literacy. The key findings of the study included that health literacy cannot yet be considered a mainstreamed notion; that translations are influenced by latent interpretations of the "literacy" component referring primarily to a meaning related to "functional literacy" or "life skill" and "competency". In most languages surveyed, several options existed within the same country. Essentially, the impact of the choice made in the translation process for health literacy is influencing the context in which it is related; hence, it 
plays a critical role for its integration and application in research, policy and practice in Europe.

\section{Health literacy as part of the academic discourse}

Although health literacy has captured little attention in Europe and has yet to make a full diffusion and immersion into common language, it has received focus in academia (Donev, Pavlekovic, \& Zaletel, 2007; Kondilis et al., 2008; von Wagner, Knight, Steptoe, $\&$ Wardle, 2007). Interestingly, the polarized understanding of 'literacy' can be detected within the academic discourse as well. Some have applied 'literacy' to health situations and labeled it 'health literacy' representing a 'functional' health literacy perspective (Rudd, Kirsch, \& Yamamoto, 2004); whereas others have linked 'health literacy' to empowerment and decision-making, considering it to be an asset and a capability rather than a risk (Kickbusch et al., 2005; Nutbeam, 2008; Peerson \& Saunders, 2009). In general, the limited attention to the term health literacy and the lack of coherent literature identified in this study is supported in research by Peerson and Saunders (Peerson \& Saunders, 2009) who emphasize that "many published papers discussing health literacy fail to identify themselves as such and may appear outside of mainstream health and medical journals".

\section{Revisiting the 'literacy' component}

The receptor analysis indicated that often 'health literacy' was translated into interrelated words such as 'health competencies', 'abilities', 'capabilities', 'skills', 'capacities', 'knowledge' and 'awareness'. This particular finding inspired a revisit to the NO$A D$ to explore the thesaurus of these words in more detail.

- Competence can be understood as "the ability to do something successfully or efficiently" or as "the scope of a person's or group's knowledge or ability", thus it can also mean "skill or ability".

- Skill means "the ability to do something well; expertise" and has its origin in late Old English scele, knowledge.

- Ability means "the capacity to do something" and "talent that enables someone to achieve a great deal".

- Capacity means "the ability or power to do, experience, or understand something".

- Knowledge means "facts, information and skills acquired by a person through experience and education; the theoretical or practical understanding of a subject as well as awareness or familiarity gained by experience of a fact or a situation".

- Awareness refers to "having knowledge or perception of a situation or a fact". 
The thesaurus of the terms most often used in the European translations clearly reveals that the terms are, in fact, closely associated. They represent nuances of the same term and the different translations even overlap in some aspects. The same phenomenon was observed in a systematic review made by Sorensen et al. (Sorensen, Van den Broucke, et al., 2012) concerning definitions of health literacy which showed that, although no unanimous definition of health literacy has been agreed upon, the identified definitions overlap to a high degree.

\section{The challenge of equivalence in translations of health literacy}

Translation and linguistic validation is a well-known aspect of health research e.g. in terms of translating questionnaires related to measurement of quality of life such as SF-36 (Aaronson et al., 1998; Leplège, Ecosse, Verdier, \& Perneger, 1998). When translating questionnaires, it is recommended to achieve several levels of equivalence, e.g.: 1) conceptual equivalence, 2) construct or item equivalence, 3 ) operational equivalence and 4) metric equivalence (Streiner \& Norman, 2008). In the current analysis, consensus has not been fully achieved with regard to the conceptual equivalence across all of the languages, which is defined as the extent to which the items in the target language are similar in meaning to the source version (Quittner et al., 2000). The translations differ slightly within languages and among the languages. As a consequence, the translation choice will implicitly influence the other levels of equivalence in a certain direction depending on the content of the particular translation. Based on the differences appearing in the European Health Literacy Glossary, it is not likely that one optimal translation will be agreed upon for each language. Instead, it is recommended to be transparent and critically reflect on the preferred choice by linking it to a definition of health literacy or a certain discourse to illustrate in which context the notion should be viewed.

\section{Translations as influential factors in health literacy agenda setting}

The diverted translations represent essentially different academic discourses within the field of health literacy as observed in research from the native English speaking countries. The translations are potential carriers of the latent meaning of literacy and will enhance efforts in certain areas and less in others depending on the particular understanding of the notion. Eventually, the loaded meaning of the translated literacy component can generate a certain agenda and guide action framework in research, policy and practice. If it is mainly a functional literacy-loaded focus, the actions often link to functional abilities to comprehend information as, for example, on medical forms. If the focus is on competences related to abilities to evaluate and act on information, the actions will link to decision-making and critical thinking in terms of applying information to a personal situation and action. In other words, the consequences of the choice of translation have a potential to influence the discourse and agenda 
setting concerning health literacy in a certain country. This effect is clearly observed in the Netherlands where the health literacy agenda is closely linked to promoting literacy skills (www.gezondheidsvaardigheden.nl). It is likely that the translational challenge for the diffusion of health literacy in the European context may be diminished if a more consistent and coherent understanding of the terminology is applied to strengthen valorisation and broader recognition of the term in research, policy and practice.

\section{Is health literacy lost in translation?}

Initially, the idea of the study was generated from the observation that health literacy translations differed in the realm of EU documents which, in turn, led to confusion and the impression that the meaning of health literacy was lost in translation and becoming a barrier for its further valorisation in Europe. However, the remarkable results of the current study offer a deeper understanding of the variety of translations and how they influence research, policy and practice. Essentially, health literacy is not lost in translation; conversely, it is clear that the translations clarify the notion and illustrate how it forms part of language as an organic phenomenon, ever growing and changing. While the terms 'health' and 'literacy' were explored independently in the source analysis since 'health literacy' was not included in encyclopedia and dictionaries, it can be argued that 'health literacy' is a legitimate concept on its own, representing all the dimensions of health and all the dimensions of literacy which is much more than the two terms in their own rights. Notably, the linguistic analysis revealed the health literacy notion's uniqueness stemming from the summarized aspects of the health and literacy components where the latent attribute of the 'literacy' component often seemed to flavor the translational direction of the combined notion. When placing the two words 'health' and 'literacy' next to each other, 'health' becomes the adjective to the noun 'literacy', and the whole can be argued to consider more than the sum of the parts. In other words, 'literacy' is defined by 'health', and a term emerges which means skills, understanding and issues, etc., relating to all the concepts grouped together under the banner of 'health'. The consistent adjacent placing of the two words, capitalized so that they take on the aura of a proper noun, will inevitably result in acceptance of the term because it is useful. The process mirrors the organic nature of language evaluation in terms of the adjective 'big' and of the noun 'apple', and put together, adjacent and capitalized - it becomes 'New York' (the Big Apple), hence, the whole is more than the sum of the parts.

In spite of its novelty, some limitations are worth noting. Although the linguistic analysis was conducted with reference to the single notion of 'health literacy', the contextual aspects were not re-assessed as part of the receptor-analysis. Future work should, therefore, encompass the notion of health literacy as well as the context in which it is anchored. By reporting the range of interpretations outlined in the Europe- 
an Health Literacy Glossary, it is evident that it is a challenge to strive for one similar translation of the term in all European languages and the idea of a consensus on the term may not be ideal. In contrast, the study provides fruitful insights in the diversity, and future research should include this aspect in translation and linguistic validation of health literacy measurements and interventions. While the study deliberately had a European focus to bridge the knowledge gap in the region, it is inherent that the research area can be increased in the future to meet the needs for a 'Global Glossary on Health Literacy'. Nevertheless, it is envisaged that the comparative results in combination with the European Health Literacy Glossary generated in this study can be regarded a valuable contribution to inform academia, health professionals, policy makers and other relevant stakeholders in terms of the critical role of translations in research, policy and practice. Essentially, the diversity of translations can be considered an enabling factor rather than a hindering factor with regard to dissemination and advancement of health literacy across Europe.

\section{Authors' contributions}

Introduction: KS, HB. Methodology: KS. Results: KS. Discussion: KS, HB. All authors read and approved the final manuscript.

\section{Acknowledgements}

The authors wish to thank Vivian Stoffels, Benjamin Tsiflidis and Vera van Heel; alumni students from European Public Health, Maastricht University, who helped identify translations for the receptor analysis receptor in the EU Health Strategy. Furthermore, thanks are conveyed to all key informants who provided their clarification of the concept, as well as partners and translators in the HLS-EU project. Christoph Aluttis is thanked for his useful feedback on the article along with Carol Herman for sharing her critical reflections on the paper, particularly the discussion. 


\section{PART 2}

Measuring health literacy

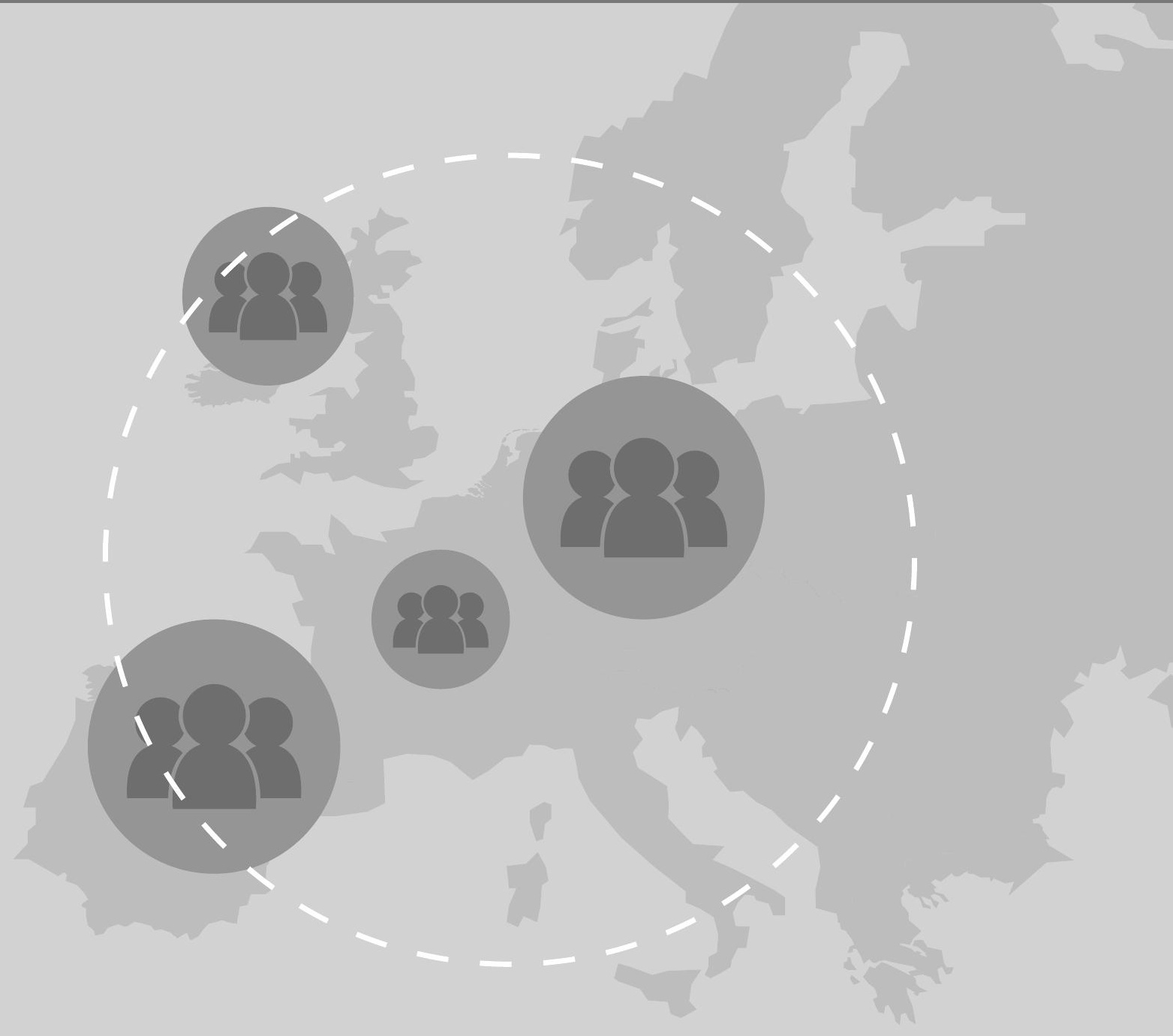


The best and most beautiful things in the world cannot be seen or even touched they must be felt with the heart.

Hellen Keller 


\section{CHAPTER 3}

Measuring health literacy in populations: HLS-EU-Q

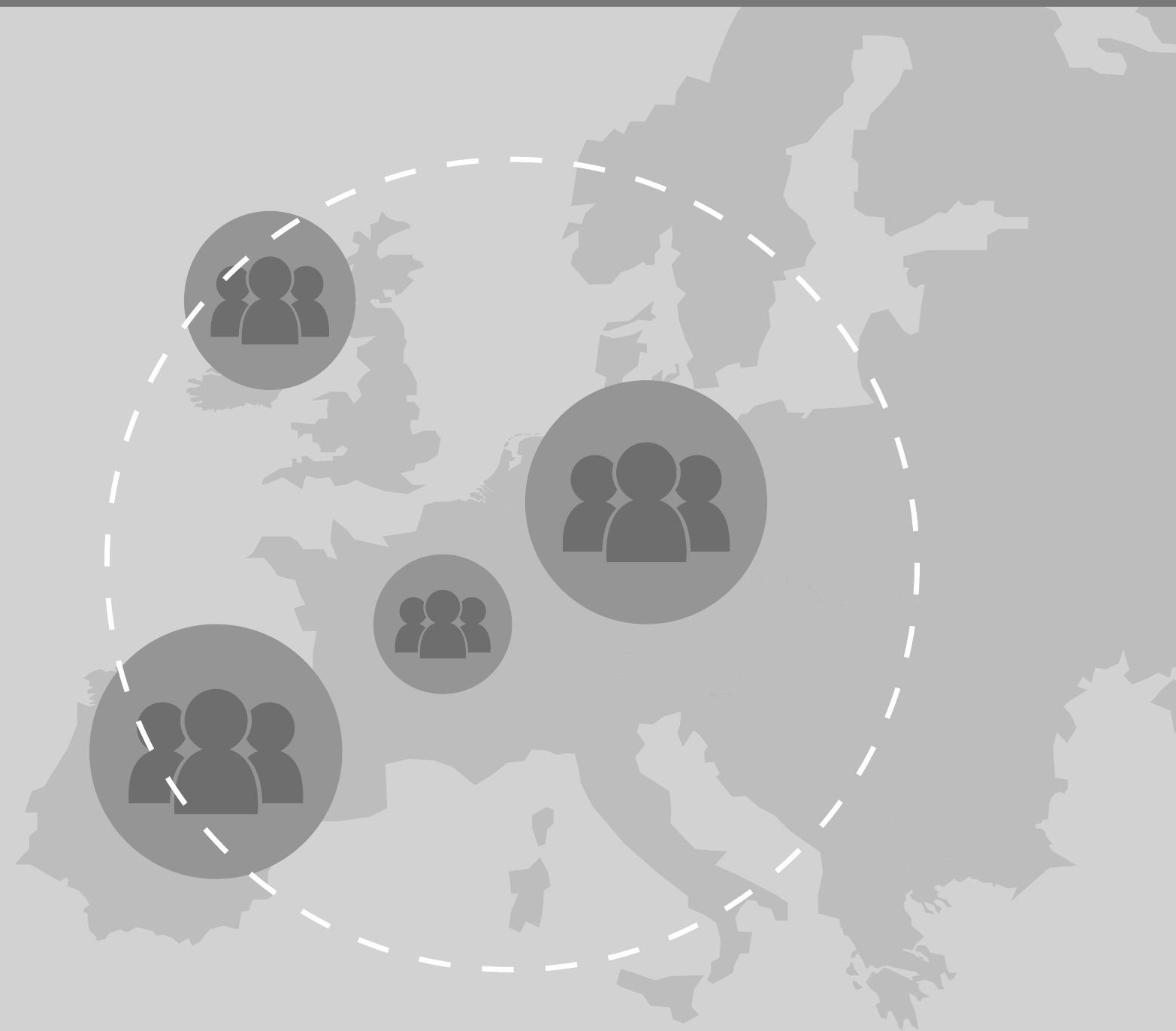

Sorensen K, Van den Broucke S, Pelikan JM, Fullam J, Doyle G, Slonska Z, Kondilis B, Stoffels V, Osborne R, Brand $\mathrm{H}$ on behalf of the European Health Literacy Project Consortium (HLS-EU). Measuring health literacy in populations: illuminating the design and development process of the European Health Literacy Survey Questionnaire (HLS-EU-Q). 


\section{Abstract}

Background Several measurement tools have been developed to measure health literacy. The tools vary in their approach and design, but few have focused on comprehensive health literacy in populations. This paper describes the design and development of the European Health Literacy Questionnaire (HLS-EU-Q), an innovative, comprehensive tool to measure health literacy in populations.

Method Based on a conceptual model and definition, the process involved item development, pre-testing, field-testing, external consultation, plain language check and translation from English to Bulgarian, Dutch, German, Greek, Polish and Spanish.

Results The process resulted in the HLS-EU-Q, which included two sections, a health literacy section and a section on determinants and outcomes associated to health literacy. The health literacy section included 47 items addressing self-reported difficulties in accessing, understanding, appraising and applying information in tasks concerning decisions making in healthcare, disease prevention and health promotion. The second section included items related to health behaviour, health status, health service use, community participation, socio-demographic and socio-economic factors.

Conclusion By illuminating the detailed steps in the design and development process of the HLS-EU-Q, it is the aim to provide a deeper understanding of its purpose, its capability and its limitations for others using the tool. By stimulating a wide application it is the vision that HLS-EU-Q will be validated in more countries to enhance the understanding of health literacy in different populations.

Key words Health literacy, survey, measurement, tool, population. 


\section{Background}

$\mathrm{H}$ ealth literacy is a composite term used to describe the capacities of persons to meet the complex demands related to health in modern society. As an outcome of health education and communication activities, it represents the cognitive and social skills that determine the motivation and ability of individuals to gain access to, understand and use information in ways that promote and maintain good health (Nutbeam, 2000b). The concept has gained increasing attention both in research and practice due to its close association to the social determinants of health (Nutbeam, 2008), health behavior and health outcomes (Paasche-Orlow et al., 2005a), health service use (Berkman et al., 2011) and quality of health systems as well as capacity building for professionals (Brach et al., 2012). Along with the increasing interest in empirical work on health literacy, there has been a growing demand for tools to measure health literacy (Pleasant, McKinney, \& Rikard, 2011).

The existing tools that purport to measure health literacy vary in their approach and design, as well as in terms of their purpose. Some tools have been developed for the purpose of screening and serve to divide people into categories with low or high levels of health literacy. Examples of this kind of tool are the Rapid Estimate of Adult Literacy in Medicine (REALM) (Davis et al., 1993; Davis, Gazmararian, \& Kennen, 2006), the Test of Functional Health Literacy (TOFHLA) (Baker, Williams, Parker, Gazmararian, \& Nurss, 1999; Bass, Wilson, \& Griffith, 2003; Hanson-Divers, 1997) and the Newest Vital Sign (NVS) (Weiss et al., 2005). As they are often used in clinical settings, these tools are necessarily short and quick and easy to use. Other tools aim at measuring a broader concept of health literacy, with a view to provide an in-depth assessment of the dimensions of health literacy, or to explore its relationships with social determinants, health behavior, health status or healthy service use such as the National Assessment of Adult Literacy survey (NAAL) (Kutner, Greenberg, Jin, \& Paulsen, 2006b), the Critical Health Competence Test (CHC) (Steckelberg, Hülfenhaus, Kasper, Rost, \& Mühlhauser, 2009) , the Swiss Health Literacy Survey (J. Wang et al., 2012), the Health Literacy Management Scale (HeLMS) (Jordan et al., 2013) and the Health Literacy Questionnaire (HLQ) (Osborne, Batterham, Elsworth, Hawkins, \& Buchbinder, 2013). Furthermore, existing health literacy measurement tools differ in terms of their administration style and their focus on specific aspects, such as the recognition and pronunciation of medical terms, numeracy, comprehension and decision-making competencies. In terms of their technical qualities, the tools differ in terms of scoring and ranges. Accordingly, the time and resources needed for application also vary (Haun, Luther, Dodd, \& Donaldson, 2012; McCormack, Valerio, Haun, \& Sorensen, 2012). Yet, in spite of the wide range of tools that are available, it is recognized that many have substantial weaknesses (Jordan, Osborne, \& Buchbinder, 2011). Existing tools are far from 
optimal and show several limitations (Griffin et al., 2010). The most apparent shortcomings of most tools are that they fail to capture all relevant aspects of health literacy and only focus on one or a few dimensions of the concept; that they have a primary focus on personal attributes at the cost of population aspects; that they have an unclear relationship to current definitions and conceptual frameworks of health literacy and that they show only weak associations with causes and outcomes of health literacy (Jordan et al., 2011). According to Pleasant et al. (Pleasant et al., 2011), a comprehensive measure of health literacy should reflect the following attributes: build explicitly on a testable theory or conceptual framework of health literacy; be multidimensional in content and methodology, to reflect the emerging theories of health literacy as a construct with multiple conceptual domains and practical components; use multiple methods; distinguish health literacy clearly from communication; treat health literacy as a latent construct, in the sense that the measure should include multiple items that sample from the conceptual domains outlined by the underlying theory or conceptual framework; honor the principle of compatibility in the sense that the measure should not focus exclusively on the clinical setting to research public health behaviors and outcomes; allow comparison and/or be commensurate across contexts including culture, life course, population group, research setting and prioritize social research and public health applications versus clinical screening (Pleasant et al., 2011).

To accomplish the European Health Literacy Survey (HLS-EU), which aimed to measure and compare health literacy in populations in selected countries in Europe (HLS-EU Consortium, 2008), the HLS-EU Consortium consisting of nine research institutes from Austria, Bulgaria, Germany ${ }^{2}$, Greece, Ireland, the Netherlands, Poland and Spain, developed the European Health Literacy Questionnaire (HLS-EU-Q). It embraces the principles outlined by Pleasant and colleagues and captures the essential dimensions of health literacy as outlined in the definition and conceptual model proposed by Sorensen et al. (Sorensen, Van den Broucke, et al., 2012).

The present paper describes the process of developing the HLS-EU-Q. Specifically, it provides a detailed outline of the structured and systematic approach that was taken concerning the item generation, pre-testing, field-testing, external consultation, plain language check and translation of the tool, with the purpose of creating and testing a concept based, multidimensional, multinational, interdisciplinary and comprehensive measurement of health literacy in populations. As such, the paper provides insight to

\footnotetext{
${ }^{2}$ While in most participating countries, samples representative for the whole country were sampled, however for feasibility reasons in Germany only the biggest state North Rhine Westphalia took part in the study!
} 
the extensive development process of designing the HLS-EU-Q, which is useful for its subsequent application and validation. Initially, the methods are described for each step performed in the development process. Then the results for each step are presented. Finally the development process and the attributes of the HLS-EU-Q are discussed in terms of quality and limitations.

\section{Method}

\section{Applying a concept validation approach}

In line with the principles outlined by Pleasant et al. (Pleasant et al., 2011), the development of the HLS-EU-Q followed a concept validation approach. Therefore, the design process was guided by the conceptual model of health literacy derived from a systematic literature review of existing definitions and conceptualisations of the concept by Sorensen et al. (Sorensen, Van den Broucke, et al., 2012). The model starts from a definition of health literacy which integrates the different aspects of health literacy as identified in the literature, stating that:

"Health literacy is linked to literacy and entails the motivation, knowledge and competencies to access, understand, appraise and apply health information in order to make judgments and take decisions in everyday life concerning healthcare, disease prevention and health promotion to maintain or improve quality of life throughout the course of life" (Sorensen, Van den Broucke, et al., 2012).

Based on this definition, the HLS-EU Consortium developed a conceptual framework outlining the main dimensions of health literacy as mentioned in the literature and integrating them in a logical model identifying the proximal and distal factors that may impact on health literacy, as well as potential consequences of health literacy in terms of health related behaviors, health outcomes and health service use (Sorensen, Van den Broucke, et al., 2012). The core of the model can be conceived of as a twelve cell matrix positing the key processes off accessing, understanding appraising and applying health-related information within three domains (Table 4.1) (Sorensen, Van den Broucke, et al., 2012).

1. The domain of healthcare, where health literacy refers to the ability to access information on medical or clinical issues, to understand medical information, to interpret and evaluate medical information and to make informed decisions on medical issues and comply with medical advice. 
2. The domain of disease prevention, where health literacy involves the ability to access information on risk factors for health, to understand information on risk factors and derive meaning, to interpret and evaluate information about risk factors and to make informed decisions to protecting against risk factors for health.

3. The domain of health promotion, where health literacy refers to the ability to regularly update oneself on determinants of health in the social and physical environment and derive meaning, to interpret and evaluate information on determinants of health in the social and physical environment and the ability to make informed decisions on health determinants in the social and physical environment and also engage in joint action.

Table 4.1 HLS-EU health literacy matrix

\begin{tabular}{|c|c|c|c|c|}
\hline & $\begin{array}{l}\text { Access/obtain } \\
\text { information relevant } \\
\text { to health }\end{array}$ & $\begin{array}{l}\text { Understand infor- } \\
\text { mation relevant to } \\
\text { health }\end{array}$ & $\begin{array}{l}\text { Process/appraise } \\
\text { information relevant } \\
\text { to health }\end{array}$ & $\begin{array}{l}\text { Apply/use infor- } \\
\text { mation relevant to } \\
\text { health }\end{array}$ \\
\hline Healthcare & $\begin{array}{l}\text { Ability to access } \\
\text { information on } \\
\text { medical or clinical } \\
\text { issues }\end{array}$ & $\begin{array}{l}\text { Ability to under- } \\
\text { stand medical } \\
\text { information and } \\
\text { derive meaning } \\
\end{array}$ & $\begin{array}{l}\text { Ability to interpret } \\
\text { and evaluate medi- } \\
\text { cal information }\end{array}$ & $\begin{array}{l}\text { Ability to make } \\
\text { informed decisions } \\
\text { on medical issues }\end{array}$ \\
\hline Disease prevention & $\begin{array}{l}\text { Ability to access } \\
\text { information on risk } \\
\text { factors for health }\end{array}$ & $\begin{array}{l}\text { Ability to under- } \\
\text { stand information } \\
\text { on risk factors and } \\
\text { derive meaning }\end{array}$ & $\begin{array}{l}\text { Ability to interpret } \\
\text { and evaluate infor- } \\
\text { mation on risk } \\
\text { factors for health }\end{array}$ & $\begin{array}{l}\text { Ability to make } \\
\text { informed decisions } \\
\text { on risk factors for } \\
\text { health }\end{array}$ \\
\hline Health promotion & $\begin{array}{l}\text { Ability to update } \\
\text { oneself on determi- } \\
\text { nants of health in } \\
\text { the social and physi- } \\
\text { cal environment }\end{array}$ & $\begin{array}{l}\text { Ability to under- } \\
\text { stand information } \\
\text { on determinants of } \\
\text { health in the social } \\
\text { and physical envi- } \\
\text { ronment and derive } \\
\text { meaning }\end{array}$ & $\begin{array}{l}\text { Ability to interpret } \\
\text { and evaluate infor- } \\
\text { mation on health } \\
\text { determinants in the } \\
\text { social and physical } \\
\text { environment }\end{array}$ & $\begin{array}{l}\text { Ability to make } \\
\text { informed decisions } \\
\text { on health determi- } \\
\text { nants in the social } \\
\text { and physical envi- } \\
\text { ronment }\end{array}$ \\
\hline
\end{tabular}

\section{Questionnaire development}

Starting from the conceptual model, a logical, systematic and structured development process was undertaken, which included the following eight steps entailing qualitative as well as quantitative methods.

1. Item generation: A Delphi procedure, which is a group facilitation technique including an iterative multistage process designed to transform opinion into group consensus (Hasson, Keeney, \& McKenna, 2000), was applied to generate items to measure each of the twelve cells of the matrix. Hence, through successive Delphi rounds items were gathered, refined and synthesized by ranking and prioritizing opinions to shape the initial version of the HLS-EU-Q. In the first Delphi round all nine research 
teams in the HLS-EU Consortium were invited to propose items related to the twelve sub-domains in the HLS-EU matrix. The second Delphi exercise dealt with the selection of items proposed in the first round. The Delphi rounds were conducted through email to permit efficient participation and respondents had opportunities to revise their inputs and comment on summary feedback at each stage.

2. Focus groups: To test the face validity of the draft questionnaire, focus groups were organised by the HLS-EU project partners in Ireland (JF, GD), Greece (BK, DA) and the Netherlands (VS, KS, SVDB). Participants provided informed consent and each group were invited to give feedback on the design, clarity and content of the questionnaire. To keep the costs low recruitment of participants for the focus groups was done via convenience sampling (Marshall, 1996), which entailed involving the most accessible, participants with knowledge on health and preferably health literacy as well as general citizen skills. Hence, the sample included students and academic staff from the three participating universities, respectively. The characteristics of the participants are outlined in Table 4.2.

Table 4.2 The characteristics of the focus group sample

\begin{tabular}{llll}
\hline Characteristics & Greece & Ireland & The Netherlands \\
\hline Number of participants & Eight & Five & Six \\
\hline Gender & $22-64$ & $24-47$ & 20 -28 \\
\hline Nationality & $2 \mathrm{men} / 6$ women & $3 \mathrm{men} / 2$ women & 2 men/ 4 women \\
& Greek (5) & Irish & German \\
& Greek/American & & Maltese \\
& & & Dutch \\
\hline Profile & Sociologists (2) & Developmental econo- & Students in the Bachelor and \\
& Philosophy and semiotics & mist; & Master Programme of Euro- \\
& Health economics & Sociologist with MSc. & pean Public Health \\
& Social worker and public & Urban planning; & \\
& health specialist & Sociologist; & \\
& Journalist and lawyer & Trainee accountant with & \\
& Elementary teacher & background in account- & \\
& Administrative worker & ancy and tax law & \\
& &
\end{tabular}

3. Pre-testing: The revised version resulting from the focus-group feedback was field-tested in two countries (Ireland and the Netherlands). The field test included 50 computer assisted face-to-face interviews in each country conducted by JF in Ireland and VS and KS in the Netherlands. To recruit participants for this field test, judgment sampling, also known as purposeful sampling was used to guarantee an equal distribution of participants 
in terms of the parameters age, gender and education (Marshall, 1996). Due to an incorrect saving procedure, data from one Dutch interview was lost, leaving a total of 99 interviews. The interview time varied from 25-90 minutes. The profile of the sample is described in Table 4.3.

Table 4.3 The characteristics of the pre-test sample

\begin{tabular}{l|l}
\hline Gender & $\begin{array}{l}42 \text { males } \\
57 \text { females }\end{array}$ \\
\hline Age & $\begin{array}{l}15-81 \text { years old } \\
\text { (mean } 43.8)\end{array}$ \\
\hline Education & $\begin{array}{l}24 \% \text { no formal education or primary education } \\
34 \% \text { secondary education } \\
\text { \% } \% \text { vocational training }\end{array}$ \\
& $32 \%$ tertiary education \\
\hline Employment & $\begin{array}{l}62 \% \text { working } \\
15 \% \text { studying } \\
23 \% \text { not working }\end{array}$ \\
\hline Health-related & $\begin{array}{l}83 \% \text { never worked in the health-care sector } \\
\text { employment }\end{array}$ \\
\hline
\end{tabular}

The methodological approach concerning data analysis involved both a qualitative and quantitative analysis of the data. For the qualitative analysis, data derived from logbooks and observations made by the interviewers, general comments and feedback from participants were scrutinized using the recommendations to refine the questionnaire. The quantitative analysis involved an item analysis, Principal Component analysis (PCA) and reliability analysis on the scores of the respondents on the questionnaire items. For the item analysis, the distribution of the responses on each item was inspected to eliminate items with a low discriminative power (i.e., 95\% or more of the answers in the same category). For the PCA, a separate analysis was performed for each domain (healthcare, disease prevention and health promotion), with the number of components fixed at four related to the four information-processing dimensions outlined in the health literacy matrix derived from the conceptual model and definitions and a VARIMAX rotation to yield maximum discrimination between the components. The resulting factor structures were inspected and items without sufficient loading $(<0.30)$ on any of the components or with a small difference in factor loading on any two components were excluded. The remaining items were again entered into PCA. This iterative procedure was repeated until an interpretable component solution was obtained. Subscales were constructed on the basis the highest compo- 
nent loading of an item. The internal consistency of the scales obtained through the PCA was tested by means of the Cronbach's alpha.

4. Expert consultation: In addition to the field test, consultations were organised with experts in the field of health and health literacy to assess the construct validity as well as the technical qualities (scaling, ordering of items...) of the questionnaire. The experts were recruited from the national advisory panels that had been established as part of the European Health Literacy Project and among the collaborative partners of the HLSEU project to gain second opinions supplementing the work carried out by the HLS-EU Consortium (Health Literacy Europe, n.d.; HLS-EU Consortium, 2008).

5. Finalisation of the questionnaire: The results of the pre-test, field test and expert consultations, respectively, were pooled and evaluated by a sub-group within the HLS-EU consortium (KS, JP, SVDB, ZS, GD) supplemented with input from the collaborative partner (RO). Items that did not fit well within the conceptual model and rationale of the questionnaire or which did not have direct or indirect relevance to the twelve sub-domains were eliminated. Items that were only indirectly associated to the rationale of the questionnaire were combined with other items. Proposed objective items such as questions related to concrete knowledge were discharged due to cultural discrepancies among the participating countries. Instead, it was decided only to include self-reporting items, similar to the practice of Chew et al. (Chew, Bradley, \& Boyko, 2004). Hence, the format of all items was changed from "statements" to "questions", and their formulation standardized so that all would assess the difficulty of a specific health relevant task, i.e.: "On a scale from very difficult to very easy, how easy would you say it is to ... followed by the question to be answered on a Likert-type scale ranging from "very easy", "easy", "difficult" or "very difficult". An answer category was added as "I don't know", which was only to be used by the interviewer. While it was ensured that the reformulated items stayed true to the original content, some new items were added, although not tested, to replace items that had been eliminated during the 'culling'. This procedure resulted in a pre-final version of the questionnaire.

6. Plain language check: The pre-final questionnaire was examined for plain language by literacy experts from the National Adult Literacy Agency in Ireland for its compliance with plain language guidelines. 
7. Translation: The English version of the final questionnaire served as a master version for translation into the six other languages to be used in the European Health Literacy Survey (Bulgarian, Dutch, German, Greek, Polish and Spanish). Two independent translators translated the questionnaire from English, to the target language. For each language, a panel consisting of national research partners, the European Health Literacy Survey Coordinator, the translators and other relevant health professionals assessed the two translations with the aim of agreeing to a formal national version of the HLS-EU-Q.

For each step, protocols were made to ensure standardization of the procedures across the countries involved.

\section{Results}

The results of each of the eight development steps are described in the following and the items included in the final questionnaire are presented in the Annex 1 at the end of this chapter.

\section{Item generation}

According to the two successive Delphi rounds, the first Delphi resulted in a total of 136 generated items across the twelve sub-domains of health literacy. Most of the items were self-report statements, to be answered on a five-point Likert scale. In addition, two to four items in the form of objective knowledge tests were formulated for each domain (healthcare, disease prevention and health promotion) to test the level of achieved health literacy. The second Delphi dealt with the selection of items proposed in the first round, and resulted in a reduction to 43 health literacy items across the twelve sub-domains. This round was based on partial consensus. The final decisions were made by the coordination team from Maastricht University [KS, SVDB and VS] in the process of creating the draft version of the questionnaire to be tested in focus groups.

\section{Focus groups}

The focus group discussions resulted in feedback on the structure, clarity and content of the questionnaire. With regard to the structure, participants suggested to change the order of items from focusing on the competencies related to information processing to a focus on the domains of healthcare, disease prevention and health promotion. Another comment with regard to the structure of the questionnaire concerned its repetitiveness. With regard to clarity, it was mentioned that the questionnaire was expert biased. Finally, with regard to content, remarks were that 1) the 'objective' 
questions and the "knowledge" questions were too difficult; 2) items might be culturally sensitive, as some questions were not generic enough to cover differences in health systems and contexts across the eight countries and 3) some items were found to prompt socially/culturally acceptable answers, e.g. related to health beliefs. In addition, there were concerns about privacy and the extent to which respondents would be willing to share their opinion and reply to the health literacy related questions and, especially, to socio-economic status related questions.

Following the incorporation of the comments and suggestions from the focus groups, a revised version of the questionnaire was made, which consisted of 47 items associated to health literacy: 22 for the healthcare domain (of which nineteen selfreport items and three objective items testing the level of achievement); 13 for the disease prevention domain (ten self-report and three test items) and eleven for the health promotion domain (nine self-report and two test items).

\section{Field test}

The qualitative analysis of field test data derived from logbooks, observations by the interviewers and general comments from both the Irish and Dutch participants pointed out that although the content of the questions was well-understood and considered as appropriate, the questionnaire was seen as too lengthy, too comprehensive, too repetitive, and too expert biased in terms of language (e.g. use of the word "hypertension" instead of "blood pressure"). It was also considered very time-consuming, with the interview time varying between 30 and 90 minutes, with an average of approximately 60 minutes. As a result of these comments, the design of the questionnaire was slightly changed after the first ten interviews. Highly similar items were combined into sets of questions, to avoid repetition and facilitate the process of answering the questions.

With regard to the quantitative analysis of the data from the field test $(N=99)$, the distribution of the responses to the items indicated that all items apart from two showed sufficient variation across the response categories (i.e. less than $95 \%$ of responses on a single category). These two items were discarded. The PCA on the selfreported items measuring health literacy in healthcare, after three iterations, resulted in a four-component solution explaining $59 \%$ of the common variance. The PCA on the self-reported items concerning disease prevention, after four iterations, resulted in a four-component solution explaining $64 \%$ of the common variance, and finally the PCA concerning health promotion, after four iterations, resulted in a four-component solution explaining $62 \%$ of the common variance. In conclusion, these results indicate that for each of the three domains (healthcare, disease prevention and health promotion) a four-component structure was found which reflected the four dimensions of accessing, understanding, appraising and applying health related information. Alpha Cronbach levels ranged between 0.51 and 0.91 . Taking into account that Cronbach's alpha is 
sensitive to a low number of items, these values suggest that the obtained scales are reasonably homogenous.

\section{Expert consultation}

The expert consultations ( $\mathrm{N}=25)$ requiring second opinions from members of the health literacy advisory boards and other collaborative partners in the HLS-EU project resulted in a series of critical reflections about the content and format of the questionnaire. The main recommendations by the experts were to: 1 ) remain true to the aim of the questionnaire (i.e. measuring health literacy in the general population) by looking at people's competencies to access, understand, appraise and apply information to take decisions in terms of disease management, risk management and health management; 2) keep the focus on people, patients and lay persons; the system efforts are not the main focus of this survey; 3 ) maintain a generic approach, recognizing that health literacy is content and context specific and that the survey will be applied across many countries and different cultural settings; 4) keep the design simple at all levels from lay-out to content such as items and response categories; 5) ensure clear language and avoid "expert" terminology; 6) keep the questionnaire easy to administer.

\section{Finalisation of the questionnaire}

The final item selection process integrating the results of the focus groups, qualitative and quantitative analysis of the field test data and expert consultations, yielded a prefinal version of the HLS-EU-Q which differed from the field tested version in several ways. While still closely related to the conceptual model and matrix, it was less repetitive; it included plain language and contained only self-reported items. The intended "objective" items such as the knowledge questions were discarded due to lack of consistency across the eight countries. Literacy items related to e.g. word recognition and text comprehension were also not included. The core questionnaire contained 47 health literacy related items, covering the twelve sub-scales of the HLS-EU matrix with 3-5 items in each scale. The number of items in each scale was a result of the consensus-based item selection process within the sub-group. The exact wording of each item is presented in the Annex.

\section{Examination for use of plain language}

The examination of the questionnaire by the National Adult Literacy Agency in Ireland (NALA) resulted in a number of smaller changes to accomplish more simple language in the final version of the questionnaire e.g. "...judge the reliability of illness-related information presented in the media?" was changed to "...judge if the information about illness in the media is reliable". The review by NALA ensured that the items were easy to read and understand which in turn facilitated that data collection would run more smoothly and quickly than was experienced in the pre-test and field-test. 


\section{Translation}

The translation of the final version of the questionnaire produced identical versions of the questionnaire in 7 languages (Bulgarian, Dutch, English, German, Greek, Polish and Spanish). In addition, the English version was adapted in its original version to be applied in Ireland and the German version was adapted for use in Germany and Austria by the translation panel and the experts involved in the respective countries to ensure its cultural applicability e.g. in terms of translations of specific words that differed or system-related items. An overview of the characteristics of the design and development process for the HLS-EU-Q is presented in Table 4.4.

\section{Discussion}

Health literacy has gained increasing attention in research and practice over the past decades (Parker \& Ratzan, 2010). With this increasing interest, there has been a growing demand for tools to measure health literacy (Pleasant \& McKinney, 2011). However, existing tools to measure health literacy focus mostly on screening for functional health literacy within clinical settings by e.g. testing word recognition or the understanding of food labels (Bass et al., 2003; Osborn et al., 2007). As HLS-EU-Q was developed for measuring the health literacy of general populations and not of specific patient groups, it does not follow a narrow clinical or medical focus, but captures a broad public health perspective. Grounded in public health, the HLS-EU-Q measures health literacy in terms of three domains where people's health is of concern and is expressed in terms of accessing, understanding, appraising and applying information to manage disease, manage risks and manage health. In other words, as a patient being ill navigating the healthcare system, as a person at risk encountering information on disease prevention and as a citizen striving for optimal health encountering health promotion offers in the community, the work place, the educational system and the market place as described in detail by Sorensen et al. (Sorensen, Van den Broucke, et al., 2012). As illustrated in the HLS-EU model the assumption is that health literacy is the outcome of informal and formal learning and health education. This means health literacy refers to an evolving set of competencies that do not remain static over time. In this definition, health is linked to quality of life and can be regarded as a means to an end rather than a fixed state, to which a person should aspire: "(Health is) the extent to which an individual or group is able on the one hand, to realize aspirations and satisfy needs and, on the other hand, to change or cope with the environment. Health is, therefore, seen as a resource for everyday life, not an object of living; it is a positive concept emphasizing social and personal resources, as well as physical capacities" (World Health Organisation's European Office, 2009). 
Table 4.4 The characteristics of the design and development of HLS-EU-Q

\begin{tabular}{|c|c|}
\hline Purpose & $\begin{array}{l}\text { The rationale for the HLS-EU-Q is to address the lack of European data on } \\
\text { health literacy in populations by providing an adequate instrument for collec- } \\
\text { tion of data, which can generate insights on national perspectives as well as a } \\
\text { comparative analysis of the state of the art of health literacy in Europe. }\end{array}$ \\
\hline Research question & $\begin{array}{l}\text { The aim of the questionnaire is to measure health literacy in (European) popu- } \\
\text { lations with reference to the HLS-EU definition and conceptual model on health } \\
\text { literacy as outlined by Sorensen et al. (Sorensen, Van den Broucke, et al., 2012). }\end{array}$ \\
\hline Scale and response format & $\begin{array}{l}\text { Likert-type scales with a four choice format "Very easy, easy, difficult, very } \\
\text { difficult"; "don't know" only to be ticked by interviewer. }\end{array}$ \\
\hline Generation of items & $\begin{array}{l}\text { Items generated by a Delphi procedure among consortium members, expert } \\
\text { consultation, and literature review with reference to the HLS-EU conceptual } \\
\text { model and a deducted matrix suggesting twelve sub-domains of health literacy. } \\
47 \text { core items were generated, placed first in order of the four information } \\
\text { processing dimensions (accessing, understanding, appraising and applying } \\
\text { health information to take decisions), then changed to be ordered in relation } \\
\text { to the three health domains in focus: healthcare, disease prevention and health } \\
\text { promotion. Within these sub-domains, items were placed in logic order accord- } \\
\text { ing to content and purpose. } \\
\text { A subsequent second section focused on antecedents and consequences of } \\
\text { health literacy related to the HLS-EU conceptual model operationalized as } 39 \\
\text { items on personal information; health service use, health behaviour, communi- } \\
\text { ty participation and socio-economic factors. }\end{array}$ \\
\hline Test and pilot of items & $\begin{array}{l}\text { Pre-test concerning face validity was made in three focus groups in Greece, } \\
\text { Ireland and the Netherlands, respectively. } \\
\text { Field test was conducted as face-to-face interviews in Ireland }(n=50) \text { and in the } \\
\text { Netherlands }(n=49) \text { to measure quantitative and qualitative aspects of the } \\
\text { measurement. }\end{array}$ \\
\hline $\begin{array}{l}\text { Amendments based on } \\
\text { item analysis or related } \\
\text { techniques }\end{array}$ & $\begin{array}{l}\text { Amendments were made based on } \\
\text { pre-test, field test, consultation process, plain language examination, transla- } \\
\text { tions. }\end{array}$ \\
\hline HLS-EU-Q versions & $\begin{array}{l}\text { HLS-EU-Q47 (core health literacy related items only); HLS-EU-Q86 (measuring } \\
\text { health literacy as well as antecedents and consequences according to the HLS- } \\
\text { EU conceptual model). }\end{array}$ \\
\hline $\begin{array}{l}\text { Creation of an indepen- } \\
\text { dent data set }\end{array}$ & $\begin{array}{l}\text { The HLS-EU-Q86 was applied as part of the European Health Literacy Survey } \\
\text { (HLS-EU) in a sample of } 8000 \text { participants from the general populations in } \\
\text { Austria, Bulgaria, Germany, Ireland, the Netherlands, Poland and Spain (HLS-EU } \\
\text { Consortium, 2012a). }\end{array}$ \\
\hline
\end{tabular}

\section{Bridging measurement gaps}

The HLS-EU-Q addresses many of the shortcomings of existing tools brought forward by e.g. Jordan et al. (Jordan et al., 2011) and Pleasant et al. (Pleasant et al., 2011). It is explicitly build on a definition and a conceptual framework of health literacy. It is multi-dimensional in content and distinguishes health literacy from communication. It 
treats health literacy as a 'latent construct' and follows a principle of compatibility, since different scales can be used for different contexts. It permits comparison in different populations and makes reference to public health rather than just clinical use. The development process of the measurement instrument has been based on a consensus approach involving nine research teams from eight countries as well as a large number of collaborating partners from Europe and abroad, all with a variety of professional educational backgrounds and experiences. Though the cross-national and crossdisciplinary group have been an advantage to ensure a wide range of perspectives in every step of the development process, the multifaceted group also remained a challenge throughout the process since the overall initial demands from all the investigators involved to content and form turned out to be too comprehensive and lengthy and therefore not feasible to administer. By respecting the feedback from users, participants and external stakeholders crucial decisions were taken during the development process, which considerably impacted the design of the final version. Eventually, the new orientation and the accompanying process of scrutinizing every item for its suitability according to agreed quality criteria paved the way for a stringent tool, matching the aim of the study while still staying true to the original ideas presented in the definition, concept and questionnaire matrix of the HLS-EU Consortium. The variation in interview time depended on the responses made by the participants as some were fast and could answer quickly, while others took longer because they found it difficult to deal and manage their health and had to reflect a longer time. The choice of a 4 point-Likert scale differentiated the responses and for those who wished to skip an answer or could not answer items, the interviewer had the option of the "I don't know" category. Due to the fine-tuning of the questionnaire the administration time was reduced to an average of 20-30 minutes including an additional section on personal back-ground variables referring to e.g. demographic and socio-economic factors that was also included in the test phases.

\section{Limitations}

Several limitations should be noted in the design and development of the HLS-EU-Q. The Delphi generated items mainly in the domains of healthcare and disease prevention and less in the domain of health promotion. Furthermore, the Delphi resulted in an excess of items, hence the process resulted in partial consensus where the coordination team adjusted the questionnaire by e.g. selecting the most preferred items. Furthermore, there was limited geographical scope applied in the testing phase. Focus groups were only carried out in three countries and the field test applying face-to-face interviews only in two. Ideally, it would have been better to include all countries, but this was not feasible within the financial constraints of the study. The data analysis regarding the field test revealed a variation of Chronbach's alpa from 0.51 to 0.91 , which warrants further research, since some of the values were considerably low. The 
overall results of the focus groups, the field test and the expert consultations generated a change in the item design, hence it is suggested that the aspect of Chronbach Alpha is taken specifically into consideration when validating the questionnaire in its application e.g. in the European Health Literacy Survey. Although the expert consultations involved experts from Ireland, Israel and Australia (see acknowledgement) adding to the multi-national perspectives already represented in the HLS-EU Consortium, an even wider representation may have been beneficial for the questionnaire's applicability in different cultures. The continuous feedback throughout the development process on problems concerning expert biases in terms of difficult words and wordings emphasized how difficult it was for the wider group of researchers to let go of expert language and underlying paradigms. In response, a plain language check was carried out by a designated Literacy Agency to ensure a final assessment of clear and transparent language in the questionnaire. The translations involved professional translators only in the final step after the plain language check. Ideally professional translations would have been carried out for the pre-test and field test as well. By illuminating the overall research process, as well as the detailed steps in the design and development process undertaken by the HLS-EU Consortium, the necessary transparency is offered for others to apply the HLS-EU-Q with a deeper understanding of its purpose, its capability and its limitations. Yet, it is also evident that further research is needed to enhance its quality and applicability in the future.

\section{Conclusion}

This paper has explained the design and development process of the European Health Literacy Questionnaire, the HLS-EU-Q. By illuminating the detailed steps in the design and development process of the HLS-EU-Q, a deeper understanding of its purpose, its capability and its limitations has been provided for others using the tool. Bearing these insights in mind, it is the vision that HLS-EU-Q with its conceptual-based, multi-facetted attributes will be validated in more countries to enhance the understanding of health literacy at population level.

\section{Acknowledgements}

The authors thank all partners in the HLS-EU Consortium for contributing to the development of the HLS-EU-Q. The HLS-EU Consortium includes

- Maastricht University, the Netherlands: Helmut Brand, Stephan Van den Broucke, Kristine Sorensen; 
- National School of Public Health, Greece: Demosthenes Agrafiodis, Elizabeth Ioannidis, Barbara Kondilis (Hellenic American University);

- University College Dublin, National University of Ireland: Gerardine Doyle, James Fullam, Kenneth Cafferkey;

- Ludwig Boltzmann Institute Health Promotion Research: Jürgen M. Pelikan, Florian Röthlin;

- The Cardinal Wyszyński Institute of Cardiology, Warsaw, Poland: Zofia Slonska;

- University of Murcia, Spain: Maria Falcon;

- Medical University, Sofia, Bulgaria: Kancho Tchamov and Alex Zhekov;

- National Institute of Public Health and the Environment, the Netherlands: Mariële Droomers, Jantine Schuit, Iris van der Heide and Ellen Uiters;

- NRW Centre for Health, Germany: Monika Mensing and Gudula Ward.

The authors also wish to acknowledge the contribution of all collaborating partners, especially the HLS-EU national advisory body on health literacy and Jennifer Lynch and her team at the National Adult Literacy Agency in Ireland; Diane Levin from Clalit Health Services in Israel; and Rachelle Buchbinder from Monash University in Australia to the development process of the HLS-EU-Q. The development of the HLS-EU-Q is a deliverable of the HLS-EU project, which is supported with grant 2007-113 from the European Commission's Health Programme.

\section{Authors' contributions}

Background: KS; SVDB; JMP; GD; ZS; BK; HB

Method: KS (Delphi, focus groups, field-test, expert consultations, translations); SVDB (Delphi; field test, expert consultations); JMP (Delphi, expert consultations, translations), JF (Delphi, focus groups, field test, expert consultations); GD (Delphi, focus groups, field test, expert consultations); ZS (Delphi, expert consultations, translations); BK (Delphi, focus groups, expert consultations, translations); RHO (expert consultations), HB (expert consultations).

Results: KS; SVDB; JMP; JF; GD; ZS; BK; RHO; HB (collaborative development of the HLSEU-Q during seminars and telephone conferences on the basis of outcomes of the design and development steps).

Discussion: KS; JMP; GD; ZS; BK; RHO; HB. 
Annex 1: The HLS-EU-Q47

\begin{tabular}{|c|c|c|c|c|c|c|c|}
\hline$\#$ & $\begin{array}{l}\text { Relation to HLS-EU } \\
\text { matrix }\end{array}$ & $\begin{array}{l}\text { On a scale from very easy to very } \\
\text { difficult, } \\
\text { how easy would you say it is to: }\end{array}$ & $\begin{array}{l}1 \\
\text { Very } \\
\text { difficult }\end{array}$ & $\begin{array}{l}2 \\
\text { Diffi- } \\
\text { cult }\end{array}$ & $\begin{array}{l}3 \\
\text { Easy }\end{array}$ & $\begin{array}{l}4 \\
\text { Very } \\
\text { easy }\end{array}$ & $\begin{array}{l}5 \\
\text { (Don't } \\
\text { know - } \\
\text { to be } \\
\text { used by } \\
\text { inter- } \\
\text { viewer } \\
\text { only) }\end{array}$ \\
\hline 1 & $\begin{array}{l}\text { Healthcare/ } \\
\text { Access information }\end{array}$ & $\begin{array}{l}\text { find information about symp- } \\
\text { toms of illnesses that concern } \\
\text { you? }\end{array}$ & & & & & \\
\hline 2 & $\begin{array}{l}\text { Healthcare/ } \\
\text { Access information }\end{array}$ & $\begin{array}{l}\text { find information on treatments } \\
\text { of illnesses that concern you? }\end{array}$ & & & & & \\
\hline 3 & $\begin{array}{l}\text { Healthcare/ } \\
\text { Access information }\end{array}$ & $\begin{array}{l}\text { find out what to do in case of a } \\
\text { medical emergency? }\end{array}$ & & & & & \\
\hline 4 & $\begin{array}{l}\text { Healthcare/ } \\
\text { Access information }\end{array}$ & $\begin{array}{l}\text { find out where to get profes- } \\
\text { sional help when you are ill? }\end{array}$ & & & & & \\
\hline 5 & $\begin{array}{l}\text { Healthcare/ } \\
\text { Understand } \\
\text { information }\end{array}$ & $\begin{array}{l}\text { understand what your doctor } \\
\text { says to you? }\end{array}$ & & & & & \\
\hline 6 & $\begin{array}{l}\text { Healthcare/ } \\
\text { Understand } \\
\text { information }\end{array}$ & $\begin{array}{l}\text { understand the leaflets that } \\
\text { come with your medicine? }\end{array}$ & & & & & \\
\hline 7 & $\begin{array}{l}\text { Healthcare/ } \\
\text { Understand } \\
\text { information }\end{array}$ & $\begin{array}{l}\text { understand what to do in a } \\
\text { medical emergency? }\end{array}$ & & & & & \\
\hline 8 & $\begin{array}{l}\text { Healthcare/ } \\
\text { Understand } \\
\text { information }\end{array}$ & $\begin{array}{l}\text { understand your doctor's or } \\
\text { pharmacist's instruction on how } \\
\text { to take a prescribed medicine? }\end{array}$ & & & & & \\
\hline 9 & $\begin{array}{l}\text { Healthcare/ } \\
\text { Appraise } \\
\text { information }\end{array}$ & $\begin{array}{l}\text { judge how information from } \\
\text { your doctor applies to you? }\end{array}$ & & & & & \\
\hline 10 & $\begin{array}{l}\text { Healthcare/ } \\
\text { Appraise } \\
\text { information }\end{array}$ & $\begin{array}{l}\text { judge the advantages and } \\
\text { disadvantages of different } \\
\text { treatment options? }\end{array}$ & & & & & \\
\hline 11 & $\begin{array}{l}\text { Healthcare/ } \\
\text { Appraise } \\
\text { information }\end{array}$ & $\begin{array}{l}\text { judge when you may need to get } \\
\text { a second opinion from another } \\
\text { doctor? }\end{array}$ & & & & & \\
\hline 12 & $\begin{array}{l}\text { Healthcare/ } \\
\text { Appraise } \\
\text { information }\end{array}$ & $\begin{array}{l}\text { judge if the information about } \\
\text { illness in the media is reliable? }\end{array}$ & & & & & \\
\hline 13 & $\begin{array}{l}\text { Healthcare/ } \\
\text { Apply information }\end{array}$ & $\begin{array}{l}\text { use information the doctor gives } \\
\text { you to make decisions about } \\
\text { your illness? }\end{array}$ & & & & & \\
\hline 14 & $\begin{array}{l}\text { Healthcare/ } \\
\text { Apply information }\end{array}$ & $\begin{array}{l}\text { follow the instructions on } \\
\text { medication? }\end{array}$ & & & & & \\
\hline 15 & $\begin{array}{l}\text { Healthcare/ } \\
\text { Apply information }\end{array}$ & $\begin{array}{l}\text { call an ambulance in an } \\
\text { emergency? }\end{array}$ & & & & & \\
\hline 16 & $\begin{array}{l}\text { Healthcare/ } \\
\text { Apply information }\end{array}$ & $\begin{array}{l}\text { follow instructions from your } \\
\text { doctor or pharmacist? }\end{array}$ & & & & & \\
\hline
\end{tabular}


Annex 1: The HLS-EU-Q47

\begin{tabular}{|c|c|c|c|c|c|c|c|}
\hline \# & $\begin{array}{l}\text { Relation to HLS-EU } \\
\text { matrix }\end{array}$ & $\begin{array}{l}\text { On a scale from very easy to very } \\
\text { difficult, } \\
\text { how easy would you say it is to: }\end{array}$ & $\begin{array}{l}1 \\
\text { Very } \\
\text { difficult }\end{array}$ & $\begin{array}{l}2 \\
\text { Diffi- } \\
\text { cult }\end{array}$ & $\begin{array}{l}3 \\
\text { Easy }\end{array}$ & $\begin{array}{l}4 \\
\text { Very } \\
\text { easy }\end{array}$ & $\begin{array}{l}5 \\
\text { (Don't } \\
\text { know - } \\
\text { to be } \\
\text { used by } \\
\text { inter- } \\
\text { viewer } \\
\text { only) }\end{array}$ \\
\hline 17 & $\begin{array}{l}\text { Disease } \\
\text { prevention/ } \\
\text { Access information }\end{array}$ & $\begin{array}{l}\text { find information about how to } \\
\text { manage unhealthy behaviour } \\
\text { such as smoking, low physical } \\
\text { activity and drinking too much? }\end{array}$ & & & & & \\
\hline 18 & $\begin{array}{l}\text { Disease } \\
\text { prevention/ } \\
\text { Access information }\end{array}$ & $\begin{array}{l}\text { find information on how to } \\
\text { manage mental health problems } \\
\text { like stress or depression? }\end{array}$ & & & & & \\
\hline 19 & $\begin{array}{l}\text { Disease } \\
\text { prevention/ } \\
\text { Access information }\end{array}$ & $\begin{array}{l}\text { find information about } \\
\text { vaccinations and health screen- } \\
\text { ings that you should have? }\end{array}$ & & & & & \\
\hline 20 & $\begin{array}{l}\text { Disease } \\
\text { prevention/ } \\
\text { Access information }\end{array}$ & $\begin{array}{l}\text { find information on how to } \\
\text { prevent or manage conditions } \\
\text { like being overweight, high blood } \\
\text { pressure or high cholesterol? }\end{array}$ & & & & & \\
\hline 21 & $\begin{array}{l}\text { Disease } \\
\text { prevention/ } \\
\text { Understand } \\
\text { information } \\
\end{array}$ & $\begin{array}{l}\text { understand health warnings } \\
\text { about behaviour such as } \\
\text { smoking, low physical activity } \\
\text { and drinking too much? }\end{array}$ & & & & & \\
\hline 22 & $\begin{array}{l}\text { Disease prevention } \\
\text { /Understand } \\
\text { information }\end{array}$ & $\begin{array}{l}\text { understand why you need } \\
\text { vaccinations? }\end{array}$ & & & & & \\
\hline 23 & $\begin{array}{l}\text { Disease prevention } \\
\text { /Understand } \\
\text { information }\end{array}$ & $\begin{array}{l}\text { understand why you need } \\
\text { health screenings? }\end{array}$ & & & & & \\
\hline 24 & $\begin{array}{l}\text { Disease Prevention } \\
\text { /Appraise } \\
\text { information }\end{array}$ & $\begin{array}{l}\text { judge how reliable health } \\
\text { warnings are, such as smoking, } \\
\text { low physical activity and drinking } \\
\text { too much? }\end{array}$ & & & & & \\
\hline 25 & $\begin{array}{l}\text { Disease prevention } \\
\text { /Appraise } \\
\text { information }\end{array}$ & $\begin{array}{l}\text { judge when you need to go to a } \\
\text { doctor for a check-up? }\end{array}$ & & & & & \\
\hline 26 & $\begin{array}{l}\text { Disease prevention } \\
\text { /Appraise } \\
\text { information }\end{array}$ & $\begin{array}{l}\text { judge which vaccinations you } \\
\text { may need? }\end{array}$ & & & & & \\
\hline 27 & $\begin{array}{l}\text { Disease prevention } \\
\text { /Appraise } \\
\text { information }\end{array}$ & $\begin{array}{l}\text { judge which health screenings } \\
\text { you should have? }\end{array}$ & & & & & \\
\hline 28 & $\begin{array}{l}\text { Disease prevention } \\
\text { /Appraise } \\
\text { information }\end{array}$ & $\begin{array}{l}\text { judge if the information on } \\
\text { health risks in the media is } \\
\text { reliable? }\end{array}$ & & & & & \\
\hline 29 & $\begin{array}{l}\text { Disease prevention } \\
\text { /Apply information } \\
\end{array}$ & $\begin{array}{l}\text { decide if you should have a flu } \\
\text { vaccination? }\end{array}$ & & & & & \\
\hline 30 & $\begin{array}{l}\text { Disease } \\
\text { prevention/ } \\
\text { Apply information }\end{array}$ & $\begin{array}{l}\text { decide how you can protect } \\
\text { yourself from illness based on } \\
\text { advice from family and friends? }\end{array}$ & & & & & \\
\hline
\end{tabular}


Annex 1: The HLS-EU-Q47

\begin{tabular}{|c|c|c|c|c|c|c|c|}
\hline \# & $\begin{array}{l}\text { Relation to HLS-EU } \\
\text { matrix }\end{array}$ & $\begin{array}{l}\text { On a scale from very easy to very } \\
\text { difficult, } \\
\text { how easy would you say it is to: }\end{array}$ & $\begin{array}{l}1 \\
\text { Very } \\
\text { difficult }\end{array}$ & $\begin{array}{l}2 \\
\text { Diffi- } \\
\text { cult }\end{array}$ & $\begin{array}{l}3 \\
\text { Easy }\end{array}$ & $\begin{array}{l}4 \\
\text { Very } \\
\text { easy }\end{array}$ & \begin{tabular}{|l}
5 \\
(Don't \\
know - \\
to be \\
used by \\
inter- \\
viewer \\
only) \\
\end{tabular} \\
\hline 31 & $\begin{array}{l}\text { Disease } \\
\text { prevention/ } \\
\text { Apply information }\end{array}$ & $\begin{array}{l}\text { decide how you can protect } \\
\text { yourself from illness based on } \\
\text { information in the media? }\end{array}$ & & & & & \\
\hline 32 & $\begin{array}{l}\text { Health promotion/ } \\
\text { Access information }\end{array}$ & $\begin{array}{l}\text { find information on healthy } \\
\text { activities such as exercise, } \\
\text { healthy food and nutrition? }\end{array}$ & & & & & \\
\hline 33 & $\begin{array}{l}\text { Health promotion/ } \\
\text { Access information }\end{array}$ & $\begin{array}{l}\text { find out about activities that are } \\
\text { good for your mental well-being? }\end{array}$ & & & & & \\
\hline 34 & $\begin{array}{l}\text { Health promotion/ } \\
\text { Access information }\end{array}$ & $\begin{array}{l}\text { find information on how your } \\
\text { neighbourhood could be more } \\
\text { health-friendly? }\end{array}$ & & & & & \\
\hline 35 & $\begin{array}{l}\text { Health promotion/ } \\
\text { Access information }\end{array}$ & $\begin{array}{l}\text { find out about political changes } \\
\text { that may affect health? }\end{array}$ & & & & & \\
\hline 36 & $\begin{array}{l}\text { Health promotion/ } \\
\text { Access information }\end{array}$ & $\begin{array}{l}\text { find out about efforts to } \\
\text { promote your health at work? }\end{array}$ & & & & & \\
\hline 37 & $\begin{array}{l}\text { Health promotion/ } \\
\text { Understand } \\
\text { information }\end{array}$ & $\begin{array}{l}\text { understand advice on health } \\
\text { from family members or friends? }\end{array}$ & & & & & \\
\hline 38 & $\begin{array}{l}\text { Health promotion/ } \\
\text { Understand } \\
\text { information }\end{array}$ & $\begin{array}{l}\text { understand information on food } \\
\text { packaging? }\end{array}$ & & & & & \\
\hline 39 & $\begin{array}{l}\text { Health promotion/ } \\
\text { Understand } \\
\text { information }\end{array}$ & $\begin{array}{l}\text { understand information in the } \\
\text { media on how to get healthier? }\end{array}$ & & & & & \\
\hline 40 & $\begin{array}{l}\text { Health promotion/ } \\
\text { Understand } \\
\text { information }\end{array}$ & $\begin{array}{l}\text { understand information on how } \\
\text { to keep your mind healthy? }\end{array}$ & & & & & \\
\hline 41 & $\begin{array}{l}\text { Health promotion/ } \\
\text { Appraise } \\
\text { information }\end{array}$ & $\begin{array}{l}\text { judge where your life affects } \\
\text { your health and well-being? }\end{array}$ & & & & & \\
\hline 42 & $\begin{array}{l}\text { Health promotion/ } \\
\text { Appraise } \\
\text { information }\end{array}$ & $\begin{array}{l}\text { judge how your housing condi- } \\
\text { tions help you to stay healthy? }\end{array}$ & & & & & \\
\hline 43 & $\begin{array}{l}\text { Health promotion/ } \\
\text { Appraise } \\
\text { information }\end{array}$ & $\begin{array}{l}\text { judge which everyday behaviour } \\
\text { is related to your health? }\end{array}$ & & & & & \\
\hline 44 & $\begin{array}{l}\text { Health promotion/ } \\
\text { Apply information }\end{array}$ & $\begin{array}{l}\text { make decisions to improve your } \\
\text { health? }\end{array}$ & & & & & \\
\hline 45 & $\begin{array}{l}\text { Health promotion/ } \\
\text { Apply information }\end{array}$ & $\begin{array}{l}\text { join a sports club or exercise } \\
\text { class if you want to? }\end{array}$ & & & & & \\
\hline 46 & $\begin{array}{l}\text { Health promotion/ } \\
\text { Apply information }\end{array}$ & $\begin{array}{l}\text { influence your living conditions } \\
\text { that affect your health and } \\
\text { well-being? }\end{array}$ & & & & & \\
\hline 47 & $\begin{array}{l}\text { Health promotion/ } \\
\text { Apply information }\end{array}$ & $\begin{array}{l}\text { take part in activities that } \\
\text { improve health and well-being } \\
\text { in your community? }\end{array}$ & & & & & \\
\hline
\end{tabular}




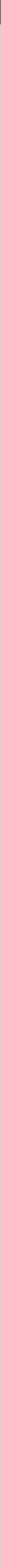


There are known knowns: there are things we know we know.

We also know there are known unknowns; that is to say, we know there are some things we do not know. But there are also unknown unknowns - the ones we don't know we don't know.

Donald Rumsfeld 


\section{CHAPTER 5}

\section{The European Health Literacy Survey}

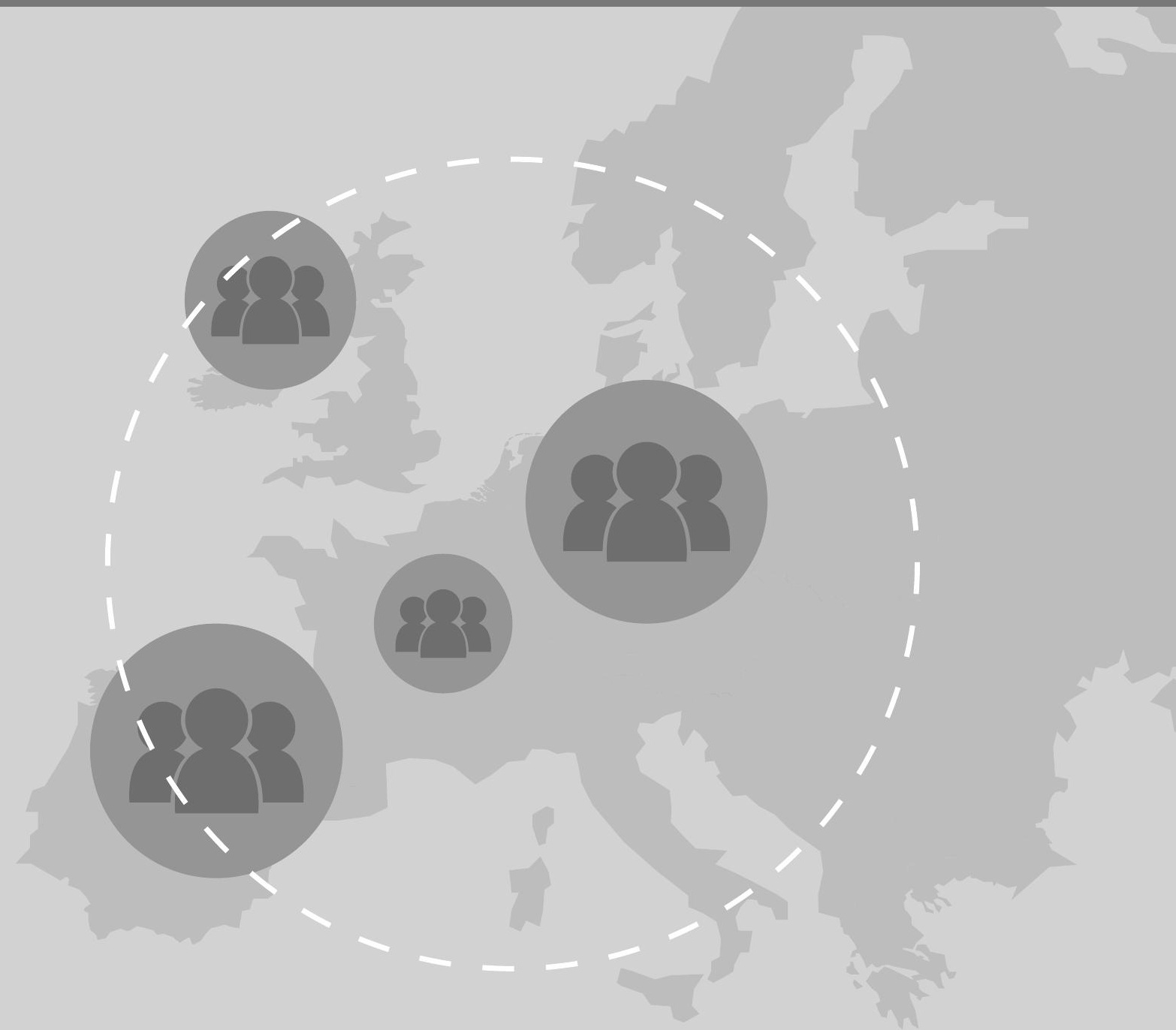

Sorensen K, Pelikan JM, Röthlin F, Ganahl K, Slonska Z, Doyle G, Fullam J, Kondilis B, Agrafiotis D, Uiters E, Falcon M, Mensing M, Tchamov K, Van den Broucke S, Brand $H$ on behalf of the European Health Literacy 


\section{Abstract}

Background Health literacy concerns the capacities of people to meet the complex demands of health in modern society. Although, health literacy of a population is recognized as important for its health, data on health literacy levels of EU Member States were thus far unavailable. The European Health Literacy Survey (HLS-EU) measured health literacy in a standardized way, providing first time data for comparison of health literacy between selected European countries.

Methods The survey took place in eight countries on a sample of 1000 persons per country. Data were collected with the HLS-EU Questionnaire using computer or paper assisted personal interviews.

Results Across countries, an average of $10 \%$ of respondents showed an inadequate level and $47 \%$ a limited (inadequate or problematic) level of health literacy. Both proportions differed considerably between countries. Subgroups within the population defined by financial deprivation, low social status, low education, and old age had a higher proportion of people with limited health literacy, suggested the presence of a social gradient in health literacy which could be confirmed by a multiple regression analysis.

Discussion Although more analysis and research is still needed, and there are some limitations of comparability between countries, the data demonstrate convincingly that limited health literacy represents an important challenge for health policies and practices across Europe, but to a different degree for different countries. The social gradient in health literacy must be taken into account explicitly when developing public health strategies to improve health literacy.

Key words Health literacy, survey, public health, measurement. 


\section{Introduction}

$\mathrm{H}$ ealth literacy has gained importance on the European health agenda. Closely linked to empowerment, it can be defined as "the ability of citizens to make sound decisions concerning health in daily life - at home, at work, in healthcare, at the market place and in the political arena" (Kickbusch \& Maag, 2008). While originally the concept was used mainly in the United States (US) and Canada to indicate a person's cognitive skills and abilities to obtain, process and understand health information to make appropriate health decisions in a medical context (Pleasant \& Kuruvilla, 2008), it is now becoming more internationally used and extended towards a public health context (Kickbusch \& Maag, 2008; Kondilis et al., 2008). This is exemplified by the inclusion of health literacy in policy documents such as the European Commission's White Paper: Together for Health (European Commission, 2007) and the Health 2020 strategy of the World Health Organisation's European Office (World Health Organisation's European Office, 2012).

However, in spite of the growing attention for the concept among European health policy makers, information about the status of health literacy in Europe remains scarce. While several studies demonstrate the prevalence of limited health literacy in the United States, Canada, Australia (Jordan et al., 2011) and Switzerland (J. Wang et al., 2012), population data on health literacy levels for the European Union (EU) have thus far remained unavailable. To address this shortcoming, a consortium of nine organisations from eight EU Member States (Austria, Bulgaria, Germany, Greece, Ireland, the Netherlands, Poland and Spain) launched the European Health Literacy (HLS-EU) project in 2009 (HLS-EU Consortium, 2008). The aims of the project included developing a model instrument to measure health literacy and generate first-time data on health literacy across diverse populations in the EU in order to make a comparative assessment and to inform European, national and regional health policies.

A systematic literature review of existing definitions and models of health literacy resulted in an integrated definition of the concept as "the knowledge, motivation and competences to access, understand, appraise and apply health information in order to make judgments and take decisions in everyday life concerning healthcare, disease prevention and health promotion to maintain or improve quality of life throughout the course of life" and a conceptual model capturing the most comprehensive evidencebased dimensions of health literacy with its main antecedents and consequences (Sorensen, Van den Broucke, et al., 2012). Health is in this regard to be understood in its broadest sense as described in the Ottawa Charter for Health Promotion (WHO Regional Office for Europe, 1986). The definition and the model of health literacy served as basis for the development of a multi-dimensional, comprehensive tool to measure health literacy in general populations called HLS-EU-Q47. 
The current paper presents selected findings from the first-time European comparative survey, carried out in the eight participating countries in 2011. More in-depth descriptions of results and methods are available in the research report developed as a deliverable of the HLS-EU project (HLS-EU Consortium, 2012a). The paper will specifically consider how health literacy is distributed in the population of the countries involved, what proportions of the population show limited health literacy, which vulnerable groups have an above average proportion of limited health literacy and whether there is a social gradient for health literacy.

\section{Methods}

\section{Questionnaire development}

Starting from the conceptual model of health literacy (Sorensen, Van den Broucke, et al., 2012), items assessing health literacy as the way people access, understand, appraise and apply information to make decisions regarding healthcare, disease prevention and health promotion were generated through a Delphi process among the HLSEU Consortium members. The resulting draft questionnaire was pre-tested for face validity in three focus groups in Greece, Ireland and the Netherlands and field-tested with 50 computer-assisted face-to-face interviews in two countries ( $n=99$ in Ireland and the Netherlands). Following the results of Principal Component Analysis (PCA) and reliability analysis of the data as well as inputs from consultations with external experts, a pre-final version of the questionnaire was obtained through a consensusbased item selection process and subjected to a "plain language" assessment by literacy experts. More details about the questionnaire development and the specific items of the HLS-EU-Q47 are presented in Sorensen et al. (Sorensen, Van den Broucke, et al., 2013).

Notably, the HLS-EU-Q included two sections with reference to the conceptual model (Sorensen, Van den Broucke, et al., 2012). The first section or "core" questionnaire (HLS-EU-Q47) contained 47 items assessing health literacy as the respondents' abilities to access, understand, appraise and apply information to make decisions concerning healthcare, disease prevention and health promotion. For each item, respondents rated the perceived difficulty of a given task or situation described by the item on a Likert scale with four categories (very easy, easy, difficult, and very difficult). This kind of operationalization uses complex health related tasks as reference following the tradition of subjective assessments of health literacy (Chew et al., 2004) and reflects the interactive or relational nature of health literacy by measuring the perceived difficulty of the task, i.e. the fit of personal competences with contextual or situational demands of social systems (Parker \& Ratzan, 2010). Differences in scores thus have to 
be attributed to differences in population competencies and/or in systems demands. The second section contained 39 items including indicators for respondent's sociodemographic and socio-economic situation, health behavior, health service use and community participation with reference to the antecedents and precedents outlined in the conceptual model (Sorensen, Van den Broucke, et al., 2012).The resulting questionnaire was translated from English into six languages (Bulgarian, German, Dutch, Greek, Polish and Spanish) by professional translators and verified by translators associated with TNS Opinion, who facilitated the data collection on behalf of the HLS-EU Consortium.

\section{Sampling}

The HLS-EU Survey was conducted as a population study according to Eurobarometer standards in eight countries drawing an independent sample of $n=1000$ persons aged 15 years and over from each country using multistage random sampling procedure in conformity with the sampling and inclusion criteria of the Eurobarometer studies (GESIS, n.d.; HLS-EU Consortium, 2012a), e.g. respondents needed to be citizens of an EU Member State. Randomly selected sampling points were used from each administrative region in a country, stratified for regions with different population size and population density (metropolitan, urban and rural areas). Two exemptions were made for logistical and cost-efficiency reasons. Germany was represented just by its most populated federal state, North-Rhine Westphalia with a population of about eighteen million. In Greece, the survey followed general Eurobarometer practice implying data collection in greater Athens, a region with about four million people.

\section{Data collection and weighting}

Data collection took place in July and August 2011 by an international survey agency (TNS-Opinion), using either computer assisted personal interviews (CAPI) or in Bulgaria and Ireland paper assisted personal interviews (PAPI). Response rates differed significantly and were higher for countries with PAPI method (75\% in Bulgaria, $69 \%$ in Ireland) compared to countries where CAPI was used (67\% in Austria, 67\% in Poland, $65 \%$ in Greece, $62 \%$ in Spain, $53 \%$ in Germany and 36\% in the Netherlands). The considerably lower response rate for the Netherlands is probably also associated to a difference in recruitment procedures, since Dutch participants according to local customs were pre-recruited by phone or email to make appointments for interviews in people's homes, rather than approached directly as in the other countries (van der Heide et al., 2013). In order to control for selection bias introduced by sampling and recruitment procedures national datasets were weighted based on the most recent available national census data, using demographic Eurobarometer standard weights. Weighting 
criteria were age groups and gender (interlocked), regions (Nuts II regions ${ }^{3}$ ) and size of municipality.

\section{Construction of the HLS-EU-Q Index Health Literacy Index}

Using the scores on the 47 core items measuring health literacy, a comprehensive general index of health literacy was constructed. For that purpose, mean based item raw scores were computed for respondents who validly answered at least $80 \%$ of all health literacy questions (which was $96.2 \%$ of the total population of all sample countries tested) and transformed via a linear transformation to a unified metric with a minimum of 0 and a maximum of 50 , where 0 represents the "least possible" and 50 represents the "best possible" health literacy score.

Following common practice for health literacy measures, index thresholds were defined and ranges for different levels of health literacy were created (Sorensen, Van den Broucke, et al., 2013). Thresholds were set according to expert assessments of the required health literacy scores, which permit a good chance of successfully pursuing one's health interests. Threshold selection was performed in such a way that the correlation patterns of the resulting health literacy levels with important covariates deviated only minimally from those of the metric health literacy scores, while the correlation between level and metric score was maximized. The resulting four levels included inadequate (0-25), problematic (>25-33), sufficient (>33-42) and excellent (>42-50) health literacy. For detecting vulnerable groups, the "inadequate" and "problematic" levels were combined to a single limited health literacy level (0-33).

\section{Other indicators}

Aside from health literacy, other indicators used for the analyses in this paper include gender (as noted by the interviewer), age (assessed by the question: "How old are you?", answered in years), education (assessed by the question "What is the highest level of education you have successfully completed?" to be answered with the help of a score card and subsequently transformed to ISCED levels) and social status (assessed by the question: "On the following scale, step ' 1 ' corresponds to 'the lowest level in the society'; step '10' corresponds to 'the highest level in the society'. Could you tell me on which step you would place yourself?", with answers recoded for the vulnerable groups and merged to status categories: 1 to 3 ='very low', $4=$ 'low', 5 = 'lower middle', 6 = 'middle', 7 ='upper middle', 8 = 'high', 9 and $10=$ 'very high'). Financial deprivation was measured by three questions which were combined to an index for easier analysis: "Are you able to pay for medication if needed to manage your own health?"

\footnotetext{
${ }^{3}$ NUTS - Nomenclature of territorial units for statistics as used by the statistical office of the European Union (EUROSTAT)
} 
and "Can you afford to see a doctor?", both, probably having a somewhat different meaning within different healthcare systems, were answered on a 4 point scale (very easy/fairly easy/fairly difficult/very difficult); and "During the last twelve months, would you say you had difficulties to pay your bills at the end of the month...?", answered on a 4-point scale (most of the time/from time to time/almost never/never).

\section{Statistical analysis}

Generally, results are presented for the eight participating countries and for the total sample. In order to have a valid country benchmark the total sample was not weighted further by country size. Besides means and standard deviations for the index, percentage distributions were calculated for levels of limited health literacy for vulnerable groups. A multivariate linear regression model (sum of squares type III, missing values excluded list-wise) was used with the total sample to measure the effects of selected social determinants on health literacy.

\section{Results}

\section{Distribution of health literacy}

As shown in Table 5.1, the distribution of the health literacy indices for both the total sample and all national samples are bell-shaped, yet with a consistently negative skew, particularly for Greece and Spain. In addition, the means are shifted towards the upper end of the scale. Both phenomena indicate a higher sensitivity of the measure for lower health literacy levels than for the higher ones. Mean scores for health literacy vary considerably between countries, with a difference of 6.56 points (Standardized Mean Difference $=0.80$ ) between the country with the highest (the Netherlands) and lowest (Bulgaria) mean health literacy level. Compared to the total sample, higher mean values were observed for Ireland, Germany and Poland, whereas that for the Netherlands is significantly $(p<0.01)$ higher than for any of the other surveyed countries. Standard deviations also vary remarkably, with a tendency of larger SD's for countries with lower health literacy averages (except for Spain). This indicates that some countries not only have a lower average level of health literacy, but also more inequality in terms of the distribution of health literacy in their population. 
Table 5.1 Descriptive Statistics of general health literacy index by country and for the total sample.

\begin{tabular}{lrrrrrrrrrr}
\hline Country & N & Min. & Max. & Mean & $\begin{array}{c}\text { Std. } \\
\text { Error }\end{array}$ & $\begin{array}{c}\text { Std. } \\
\text { Deviation }\end{array}$ & Skewness & $\begin{array}{c}\text { Std. } \\
\text { Error }\end{array}$ & Kurtosis & $\begin{array}{c}\text { Std. } \\
\text { Error }\end{array}$ \\
\hline Austria & 979 & 3.19 & 50 & 31.95 & 0.24 & 7.63 & -0.07 & 0.08 & -0.02 & 0.16 \\
Bulgaria & 925 & 0.00 & 50 & 30.50 & 0.30 & 9.17 & -0.15 & 0.08 & -0.01 & 0.16 \\
Germany & 1045 & 7.09 & 50 & 34.49 & 0.24 & 7.87 & -0.01 & 0.08 & -0.43 & 0.15 \\
Greece & 998 & 3.55 & 50 & 33.57 & 0.27 & 8.48 & -0.54 & 0.08 & 0.57 & 0.16 \\
Ireland & 959 & 11.59 & 50 & 35.16 & 0.25 & 7.79 & -0.17 & 0.08 & -0.25 & 0.16 \\
Netherlands & 993 & 2.48 & 50 & 37.06 & 0.20 & 6.40 & -0.12 & 0.08 & $-0,21$ & 0.16 \\
Poland & 921 & 0.00 & 50 & 34.45 & 0.26 & 7.98 & -0.39 & 0.08 & 0.95 & 0.16 \\
Spain & 974 & 15.6 & 50 & 32.88 & 0.20 & 6.10 & 0.42 & 0.08 & 0.51 & 0.16 \\
\hline TOTAL & 7795 & 0.00 & 50 & 33.78 & 0.09 & 7.95 & -0.26 & 0.03 & 0.29 & 0.06 \\
\hline
\end{tabular}

\section{Proportion of low health literacy in the population}

For the total sample, at least one out of ten participants in the survey $(12.4 \%)$ has inadequate health literacy. However, the differences between Member States are again substantial, with only $1.8 \%$ of the sample in the Netherlands having inadequate health literacy against $26.9 \%$ in Bulgaria (Figure 5.1). Almost every second respondent $(47.6 \%)$ in the total sample has limited (inadequate or problematic) health literacy, with the prevalence ranging from $28.7 \%$ in the Netherlands to more than $62.1 \%$ in Bulgaria.

\section{Vulnerable groups for limited health literacy}

As shown in Table 5.2, there are specific subgroups where the proportion of people with limited health literacy considerably exceeds the average of $47.6 \%$ observed for the overall sample. This holds true for people with poor health status, high use of healthcare services, low socio-economic status, lower education and older age. The highest proportion of limited health literacy is observed for those with "very bad" (78.1\%) or "bad" (71.8\%) self-assessed health status, for those with more than one long term illness (61\%) and those reporting 6 or more doctor visits in the last 12 month (58.9\%). Therefore, worse health and thus higher demands for health services seem to be accompanied by lower levels of health literacy. 


\begin{tabular}{|c|c|c|c|c|c|}
\hline \multicolumn{2}{|c|}{ - inadequate general-HL } & - problematic general-HL & Eufficient general-HL & \multicolumn{2}{|c|}{ = excellent general-HL } \\
\hline Austria & $18,2 \%$ & $38,2 \%$ & & $33,7 \%$ & $9,9 \%$ \\
\hline Bulgaria & $26,9 \%$ & 35,2 & & $26,6 \%$ & $11,3 \%$ \\
\hline Germany & $11,0 \%$ & $35,3 \%$ & $34,1 \%$ & & $19,6 \%$ \\
\hline Greece & $13,9 \%$ & $30,9 \%$ & $39,6 \%$ & & $15,6 \%$ \\
\hline Ireland & $10,3 \%$ & $29,7 \%$ & $38,7 \%$ & & $21,3 \%$ \\
\hline Netherlands & $1,8 \% \quad 26,9 \%$ & & $46,3 \%$ & & $25,1 \%$ \\
\hline Poland & $10,2 \%$ & $34,4 \%$ & $35,9 \%$ & & $19,5 \%$ \\
\hline Spain & $7,5 \%$ & $50,8 \%$ & & $32,6 \%$ & $9,1 \%$ \\
\hline TOTAL & $12,4 \%$ & $35,2 \%$ & $36,0 \%$ & & $16,5 \%$ \\
\hline
\end{tabular}

Figure 5.1: Levels of general health literacy index by country and for the total sample.

Table 5.2 Percentages of individuals with limited health literacy in selected vulnerable groups for countries and for the total sample.

Austria Bulgaria Germany Greece Ireland Nether- Poland Spain Total lands

\begin{tabular}{|c|c|c|c|c|c|c|c|c|c|c|}
\hline \multirow[t]{2}{*}{ Health } & Very bad & 100.00 & 87.80 & 54.90 & 88.30 & 49.50 & 47.40 & 77.20 & 94.80 & 78.10 \\
\hline & Bad & 84.20 & 82.40 & 54.90 & 80.30 & 57.20 & 41.40 & 71.20 & 75.30 & 71.80 \\
\hline $\begin{array}{l}\text { Long term } \\
\text { illness }\end{array}$ & $\begin{array}{l}\text { Yes more } \\
\text { than one }\end{array}$ & 78.50 & 83.30 & 58.50 & 73.80 & 45.30 & 32.60 & 54.30 & 69.50 & 61.00 \\
\hline $\begin{array}{l}\text { Doctor } \\
\text { visits }\end{array}$ & $\begin{array}{l}6 \text { times or } \\
\text { more }\end{array}$ & 70.00 & 74.00 & 56.20 & 58.40 & 46.60 & 30.80 & 54.10 & 69.40 & 58.90 \\
\hline \multirow[t]{2}{*}{ Age } & 76 or older & 72.60 & 75.40 & 53.90 & 72.30 & 46.00 & 28.80 & 65.50 & 71.10 & 60.80 \\
\hline & $\begin{array}{l}\text { Between } 66 \\
\text { and } 75\end{array}$ & 71.40 & 79.70 & 39.70 & 66.20 & 37.10 & 30.40 & 58.70 & 77.10 & 58.20 \\
\hline \multirow[t]{2}{*}{ Education } & Levels 0 or 1 & 62.20 & 75.40 & 58.90 & 77.30 & 49.10 & 40.40 & 91.90 & 74.20 & 68.00 \\
\hline & Level 2 & 69.70 & 77.60 & 57.10 & 55.80 & 52.00 & 35.00 & 59.60 & 59.70 & 57.20 \\
\hline $\begin{array}{l}\text { Problems } \\
\text { with } \\
\text { paying bills }\end{array}$ & $\begin{array}{l}\text { Most of the } \\
\text { time }\end{array}$ & 67.10 & 75.20 & 46.80 & 60.70 & 61.20 & 33.50 & 42.20 & 61.70 & 63.40 \\
\hline \multirow{2}{*}{$\begin{array}{l}\text { Social } \\
\text { status }\end{array}$} & Very Low & 78.50 & 79.70 & 58.80 & 79.50 & 64.00 & 49.90 & 59.80 & 84.30 & 73.90 \\
\hline & Low & 59.40 & 62.10 & 63.90 & 57.40 & 53.30 & 48.40 & 63.80 & 59.20 & 60.00 \\
\hline
\end{tabular}

With regard to socio-economic status, higher proportions of people with limited health literacy are found among those whose social status is "very low" (73.9\%) or "low" (60 $\%$ ), followed by those with lowest or low levels of education (68\% and $57.2 \%$ ), by those who have permanent problems paying bills (63.4\%), are between 66 and 75 years $(58.2 \%)$ or are 76 years of age or older (60.8\%). Again, there are marked differences between countries. In some countries proportions of limited health literacy 
often exceed $75 \%$ for certain vulnerable groups, whereas in the Netherlands they generally stay below $50 \%$.

\section{Social gradient for health literacy}

The finding of specific social groups with higher proportions of people with limited health literacy as described above also suggests the existence of a social gradient for health literacy. This is confirmed by the substantial raw (bivariate) correlations between health literacy and selected possible social determinants: the raw correlation is strongest for financial deprivation $(r=-.34)$, whereas the negative sign of the correlation indicates, lower health literacy when financial deprivation increases. For social status the raw correlation of health literacy $(r=.31)$ is almost as strong, followed by education $(r=.25)$, age $(r=-.16)$, the older the worse is health literacy and gender $(r=$ $.05)$, indicating that men tend to have slightly lower health literacy. Concerning age, in this kind of cross-sectional study it is not just age, but also generation that is measured by the age-cohort.

However, as these social determinants are inter-correlated, a multivariate linear regression, and controlling for possible covariates, gives a better assessment of the direct effects of these factors on health literacy. A multivariate model - with all five social indicators introduced as independent variables - yields an adjusted $R^{2}=17.4 \%$ $(p=.000)$ for explained variance of health literacy. Financial deprivation remains the strongest predictor of low health literacy, followed by social status, education, age and gender.

Table 5.3 Multivariate linear regression model for general health literacy index as dependent variable and socio-demographic indicators as predictors.

\begin{tabular}{|c|c|c|c|c|c|c|c|c|c|}
\hline & \multirow{2}{*}{$\begin{array}{c}\text { Coeffi- } \\
\text { cients } \\
\text { B }\end{array}$} & \multicolumn{3}{|c|}{ Standardized Coefficients } & \multicolumn{2}{|c|}{$\begin{array}{l}95 \% \text { Confidence } \\
\text { Interval for B }\end{array}$} & \multicolumn{3}{|c|}{ Pearson Correlations } \\
\hline & & Beta & $\mathrm{t}$ & Sig. & $\begin{array}{l}\text { Lower } \\
\text { Bound }\end{array}$ & $\begin{array}{l}\text { Upper } \\
\text { Bound }\end{array}$ & $\begin{array}{c}\text { Raw } \\
\text { correlation }\end{array}$ & $\begin{array}{c}\text { Partial } \\
\text { correlation }\end{array}$ & $\begin{array}{c}\text { Semi- } \\
\text { partial } \\
\text { correlation }\end{array}$ \\
\hline (Constant) & 28.76 & & 62.43 & 0.000 & 27.86 & 29.67 & & & \\
\hline Gender & 1 & 0.06 & 5.86 & 0.000 & 0.67 & 1.33 & 0.05 & 0.07 & 0.06 \\
\hline Age & -0.04 & -0.09 & -8.52 & 0.000 & -0.05 & -0.03 & -0.16 & -0.10 & -0.09 \\
\hline Education & 0.79 & 0.13 & 11.33 & 0.000 & 0.65 & 0.93 & 0.25 & 0.13 & 0.12 \\
\hline $\begin{array}{l}\text { Financial } \\
\text { Deprivation }\end{array}$ & -1.92 & -0.24 & -19.91 & 0.000 & -2.11 & -1.73 & -0.34 & -0.23 & -0.21 \\
\hline $\begin{array}{l}\text { Social } \\
\text { Status }\end{array}$ & 0.69 & 0.14 & 11.39 & 0.000 & 0.57 & 0.81 & 0.31 & 0.13 & 0.12 \\
\hline
\end{tabular}

Predictors: Gender (Male=0, Female=1); Age (in years); Education (ISCED Levels); Financial deprivation (Factor scores - low deprivation towards high deprivations); Social Status (1=very low, 10=very high) 


\section{Discussion}

The HLS-EU project is the first study to provide population data on health literacy at EU level and to enable a comparison of health literacy levels between selected Member States, using a standard survey questionnaire (based on a comprehensive conceptual and logic model), applying Eurobarometer standards (GESIS, n.d.) and ensuring consistency in data collection by using one European-wide represented agency.

Whereas more than $10 \%$ of the total surveyed population had an inadequate level of health literacy, this proportion varied between $1.8 \%$ and $26.9 \%$ by country. In turn, almost one in two citizens were affected, when considering the proportion of limited health literacy, which varied between $29 \%$ and $62 \%$. The considerable proportions imply that the health literacy deficit is an under-estimated challenge among European countries. Moreover, across countries, there are specific subgroups in the population with a higher proportion of people with limited health literacy than in the general population, suggesting specific vulnerable groups. The presence of a social gradient in health literacy appears to be confirmed. Financial deprivation is the strongest predictor of health literacy, followed by social status, education and age, with gender having a minor effect. Financial deprivation is the strongest predictor of health literacy, followed by social status, education, and age, with gender having a minor effect. Thus, the HLS-EU data extend the well-documented phenomenon of a social gradient for health and for literacy (Goldberg, 2007; Marmot, 2006). The data set is rich, and much more detailed analysis is still possible, already ongoing and partly available at both national and comparative levels (HLS-EU Consortium, 2012a; van der Heide et al., 2013) $[11,16]$.

But certain unavoidable limitations apply to the study and its design. Due to limited financial resources the field testing was limited to three countries, the survey was carried out in only eight out of $27 \mathrm{EU}$ Member States; the sample size was restricted to 1000 respondents for each sample country; leaving out non-EU-citizens living in the participating countries according to Eurobarometer methodology; countries differed in their geographical representation within countries (Germany and Greece); data collection methodology differed (CAPI vs. PAPI; pre-recruiting) and response rates by country partly confined strict comparability between countries. The HLS-EU-Q is a subjective measurement and as such it does not include any objective items to e.g. measuring functional health literacy. Nevertheless, this first European comparative assessment reveals important insights on how health literacy levels vary considerably both within and between the EU Member States. Yet, to better understand the causes of the national differences, more analysis and specific further research is necessary. Apart from a few items the measure seems generalizable within a European setting and, with its flexible matrix structure, it can be adapted to suit national needs. 
In conclusion, the HLS-EU survey has extended the evidence base on health literacy by measuring health literacy in eight EU Member States. Limited health literacy and a social gradient in health literacy represent important challenges for health policies and practices in Europe, but to a different degree for participating Member States. This health literacy deficit and inequality needs to be addressed by European and national health planners and policy makers dealing with the social determinants of health and health inequalities and developing appropriate public health and health promotion strategies.

To that effect, a two-sided approach must be pursued, as recommended by Parker and Ratzan: to strengthen the personal knowledge, motivation and competences of citizens and patients to take well-informed health decisions; to decrease the complexity of society as a whole, and particularly of the healthcare system (Parker \& Ratzan, 2010), so as to better guide, facilitate and empower citizens to managing their health in a sustainable manner (Kickbusch, Pelikan, Apfel, \& Agis, 2013). Efforts must be made to strengthen the health literacy of citizens by re-designing user-friendly and userinvolving systems (Brach et al., 2012), adjusting curricula and training of health professionals to enable them to better meet the challenge of the health literacy deficit and increasing expectations of patients to be active partners in their care. Due to the considerable differences in health literacy status between the countries, such measures need to be tailored towards the specific social, economic, cultural and educational situation of a country, whereas the European level provides possibilities for comparison, exchanging, benchmarking and learning from best practices.

For the latter, the HLS-EU-Q47 survey tool can be very useful to identify strengths and weaknesses in health literacy levels, both within countries and in comparison with other countries. Based on a well thought-through conceptual model of health literacy and validated on a large, cross-national sample of EU citizens following the wellestablished Eurobarometer methodology (GESIS, n.d.), it allows for a reliable and valid measurement of health literacy and its components. By regularly monitoring health literacy and extending the number of countries that use the survey tool and integrating it in the EU's health reporting and monitoring system, it can significantly support political and professional decision-making to improve health literacy in Europe and, hence, contribute to the further improvement of the population's health.

\section{Key points}

- The European Health Literacy Study measured health literacy in eight countries ( $n=8 \times 1000$ people) using the new measurement tool HLS-EU-Q.

- On average every second person surveyed showed limited health literacy. 
- A social gradient was demonstrated in the surveyed population.

- Europe is diverse concerning health literacy.

- Monitoring health literacy can support professional and political decision-making to improve health literacy in Europe to the benefit of population's health.

- Therefore, health literacy has to gain importance on the European agenda.

\section{Authors' contribution}

Introduction: KS, JMP, ZS, JF, GD, BK, DA, UI, MF, MM, KT, SVDB.

Methods: KS, JMP, ZS, JF, GD, BK, DA, UI, MF, MM, KT, HB.

Results: JMP, FR, KG.

Discussion: KS, JMP, ZS, JF, GD, BK, DA, UI, MF, MM, KT, SVDB.

\section{Acknowledgements}

The HLS-EU Survey formed part of the achievements of the European Health Literacy project (HLS-EU) from 2009-2012, awarded with the European Health Award 2012. The main objectives of the project were to measure health literacy in eight European countries; to establish a network of professionals on health literacy in Europe and to organize initiatives promoting health literacy at national levels. The HLS-EU project was cofinanced by the European Commission and national organisations. It was managed by the HLS-EU Consortium with Maastricht University as leading partner and eight institutes as associated partners. More than twenty institutes from Europe and abroad followed the project as collaborating partners and the HLS-EU Consortium is grateful for their support and commitment to the project. 



\section{PART 3}

Advancing health literacy in Europe by developing health literate systems, businesses and societies

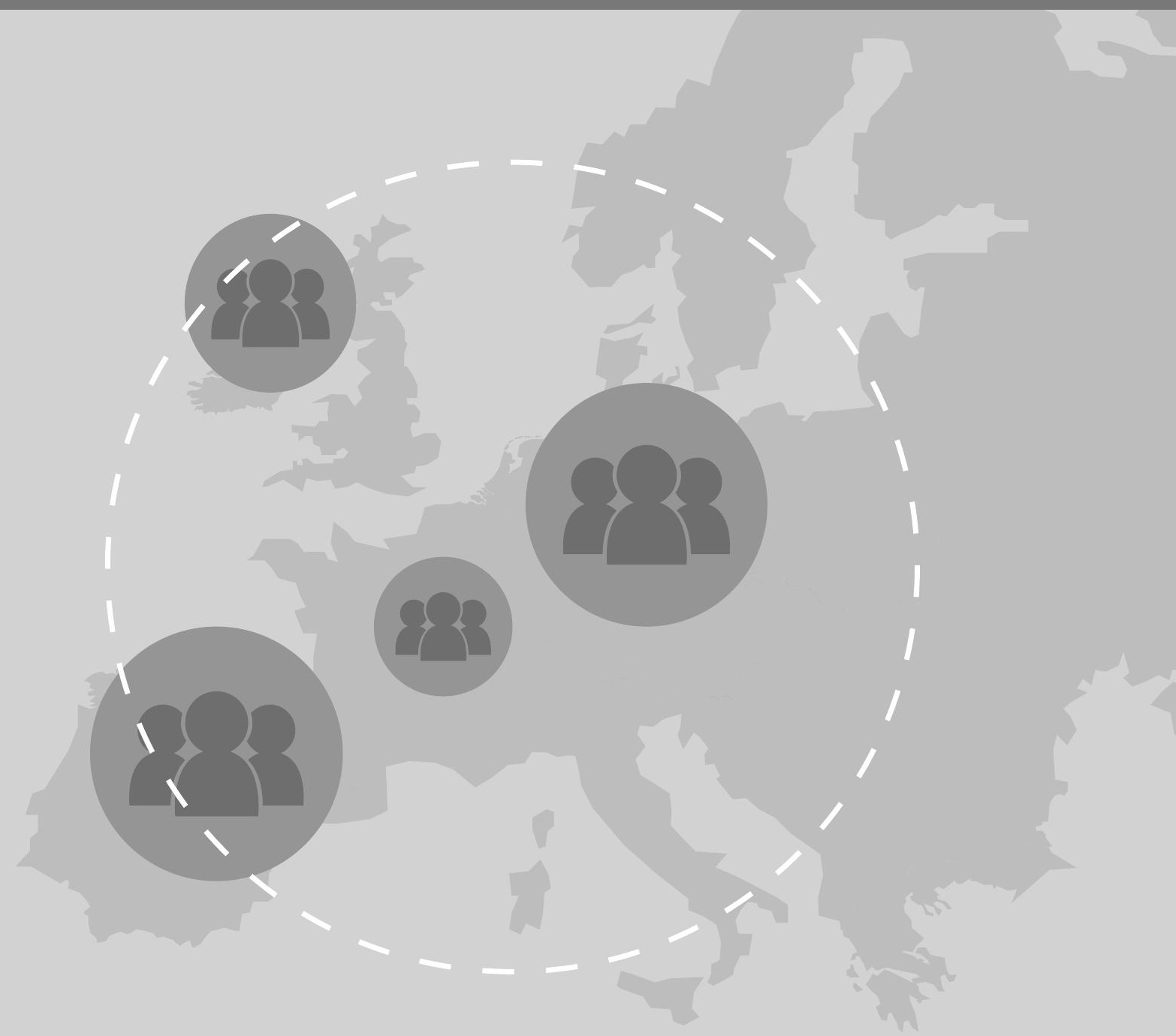


Know Thyself.

Oracle in Delphi 


\section{CHAPTER 6}

\section{The movers and shakers of health literacy \\ - a Danish case study}

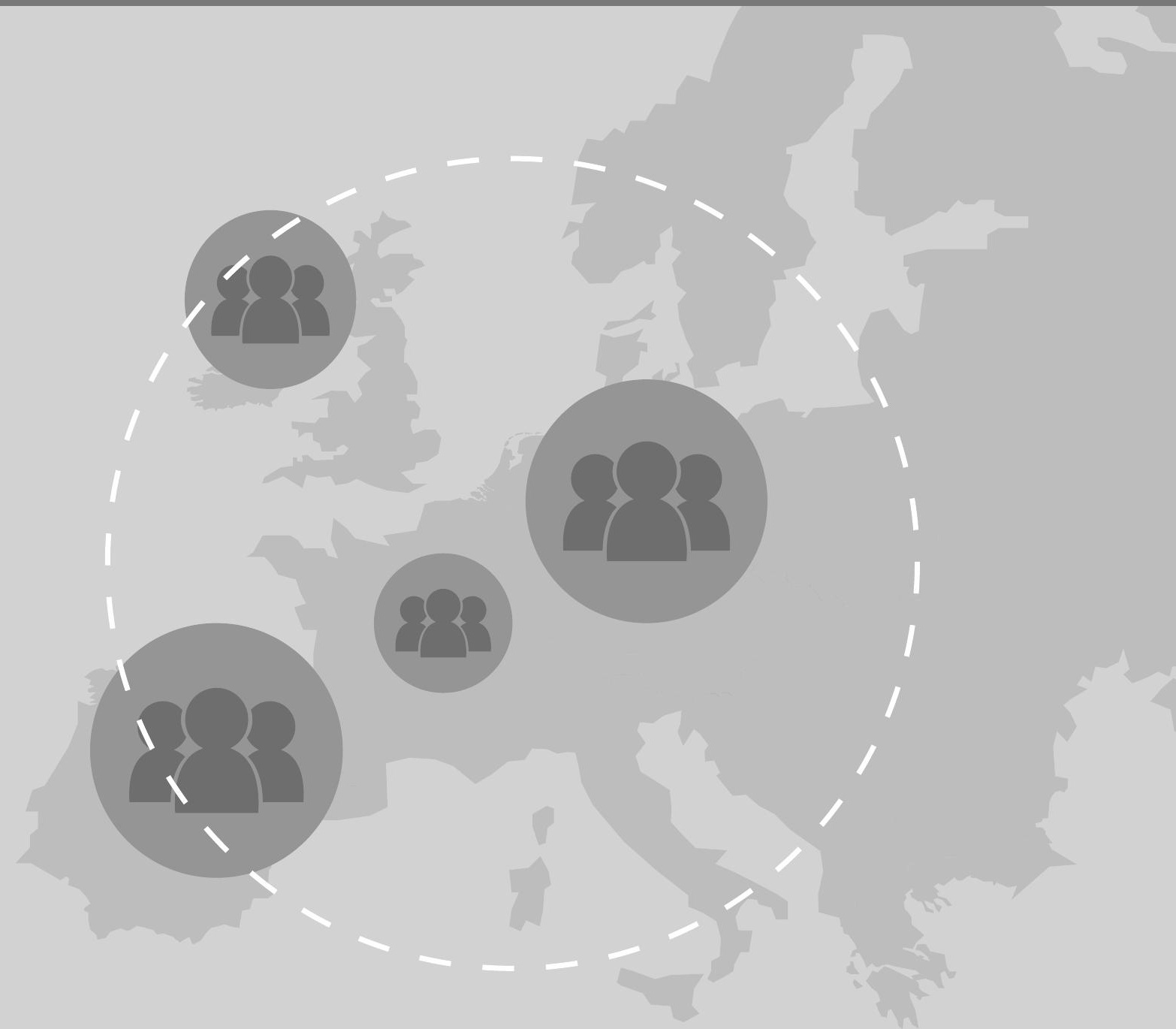

Sorensen K, Nørgaard O, Maindal HT, Brand H. Health literacy in Denmark: a stakeholder analysis to identify movers and shakers of its integration into research, policy and practice. Scandinavian Journal of Public Health - in review, March 2013 


\section{Abstract}

Aims There is a growing awareness of the health literacy challenge in Europe made evident by the European Health Literacy Study. In response, this study aimed to map how the concept of health literacy is manifested in research, policy and practice in Denmark.

Methods Data was generated through internet search engines, filtered to include texts in Danish and a stakeholder analysis was conducted to identify the movers and shakers in the field.

Results The analysis revealed a broad range of stakeholders in various sectors applying the notion of health literacy, yet, the field of health literacy appears fragmented with isolated initiatives and low impact. Notably, there is a lack of leadership and no explicit and coherent goals or shared vision.

Conclusions An increased focus on health literacy is expected to qualify healthcare, disease prevention and health promotion at individual as well as societal level for the benefit of population health. However, it will require not only the profound interest in health literacy from stakeholders involved, but also the legitimacy, power, priority and leadership to change the current status quo. 


\section{Introduction}

$\mathrm{T}$ he European Health Literacy Survey (HLS-EU) indicates that limited health literacy is a public health challenge in several European countries as $47 \%$ on average face difficulties in managing health (HLS-EU Consortium, 2012a). The phenomenon of limited health literacy in Europe is in line with research elsewhere (Berkman et al., 2011; Paasche-Orlow, Parker, Gazmararian, Nielsen-Bohlman, \& Rudd, 2005b). Generally, health literacy can be defined as people's knowledge, motivation and competences to access, understand, appraise and apply health information to make judgments and decisions in everyday life concerning healthcare, disease prevention and health promotion to maintain or improve quality of life during the life course (Sorensen, Van den Broucke, et al., 2012). It is a critical empowerment strategy to increase people's control over their health, their ability to seek out information and their ability to take responsibility (Kickbusch \& Maag, 2008).

Recently, the notion of health literacy was introduced in the Nordic health research (Lindström \& Eriksson, 2011; Mårtensson \& Hensing, 2012; The Nordic Health Literacy Network, n.d.). In Denmark, the Danish Health and Medicines Authority conducted a review of the health literacy concept and its potential for application in the Danish public health context in 2009 (Madsen, Højgaard, \& Albæk J., 2009); however, an initial literature search in health related scientific databases revealed only few results (see Box 1). Hence, it is anticipated that so far, the Danish field of health literacy remains only marginally researched. Therefore, it seems appropriate to examine the status and progress of introducing health literacy in Denmark from a broader point of view. Accordingly, the aim of this study is to identify the movers and shakers in the Danish field of health literacy, hence the people or organisations, who initiate change and influence by inciting, promoting or directing actions in an a certain area (MerriamWebster Dictionary, n.d.; The Phrase Finder, n.d.). Through the application of a stakeholder analysis, it is possible to identify relevant stakeholders (Brugha \& Varvasovszky, 2000; Varvasovszky \& Brugha, 2000) pursuing a potential to influence the future of health literacy in Denmark.

BOX 1

A search in the databases MEDLINE, EMBASE, PsycInfo and Web of Science for the term "health literacy" combined with Denmark*, Danmark*, Danish, Dane* or dansk* (in all relevant database fields, including English and, if available, Danish titles and abstracts and the authors' affiliation) resulted in 44 records from scientific journals. Only very few originated from Denmark and none examined the concept of health literacy in a Danish context. 


\section{Methods}

The study was based on a data collection of references to texts available on the Internet followed by a stakeholder analysis defined as "an approach, a tool or a set of tools for generating knowledge about actors - individuals as organisations - so as to understand their behaviour, intentions, interrelations and interests" (Mitchell, Agle, \& Wood, 1997). The approach is regularly applied in health services research (Horev \& Babad, 2005; Leto di Priolo, Fehervary, Riggins, \& Redmond, 2012).

The data was collected through searches in three common Internet search engines: Google (Google, n.d.-a), Google Scholar (Google, n.d.-b), Yahoo! (Yahoo!, n.d.) and Bing (Bing, n.d.). We conducted two separate searches in each search engine using the terms "health literacy" (including the quotes) and sundhedskompetence (including its plural form sundhedskompetencer). While there is no established Danish term for health literacy (Madsen et al., 2009), 'sundhedskompetence' ('health competence' in English) was chosen, because it refers to the notion appearing in Danish translations of health literacy in European Union documents (Europakommissionen, 2007; European Commission, 2007) and in the Danish review (Madsen et al., 2009). In Google we utilized multiple settings: the search results were limited to websites in the Danish language; a redundancy filter was applied to omit entries very similar to those already retrieved; and localization was set to Denmark to ensure that search results were displayed as on a computer placed in Denmark. Equivalent settings are not available in Google Scholar, hence we only limited the search results to websites in the Danish toplevel domain (".dk"). For the searches in Yahoo! and Bing we used the Danish version of the search engine websites and set the preferred language of the search results to Danish. The searches were conducted in September 2012 and updated in February 2013. 


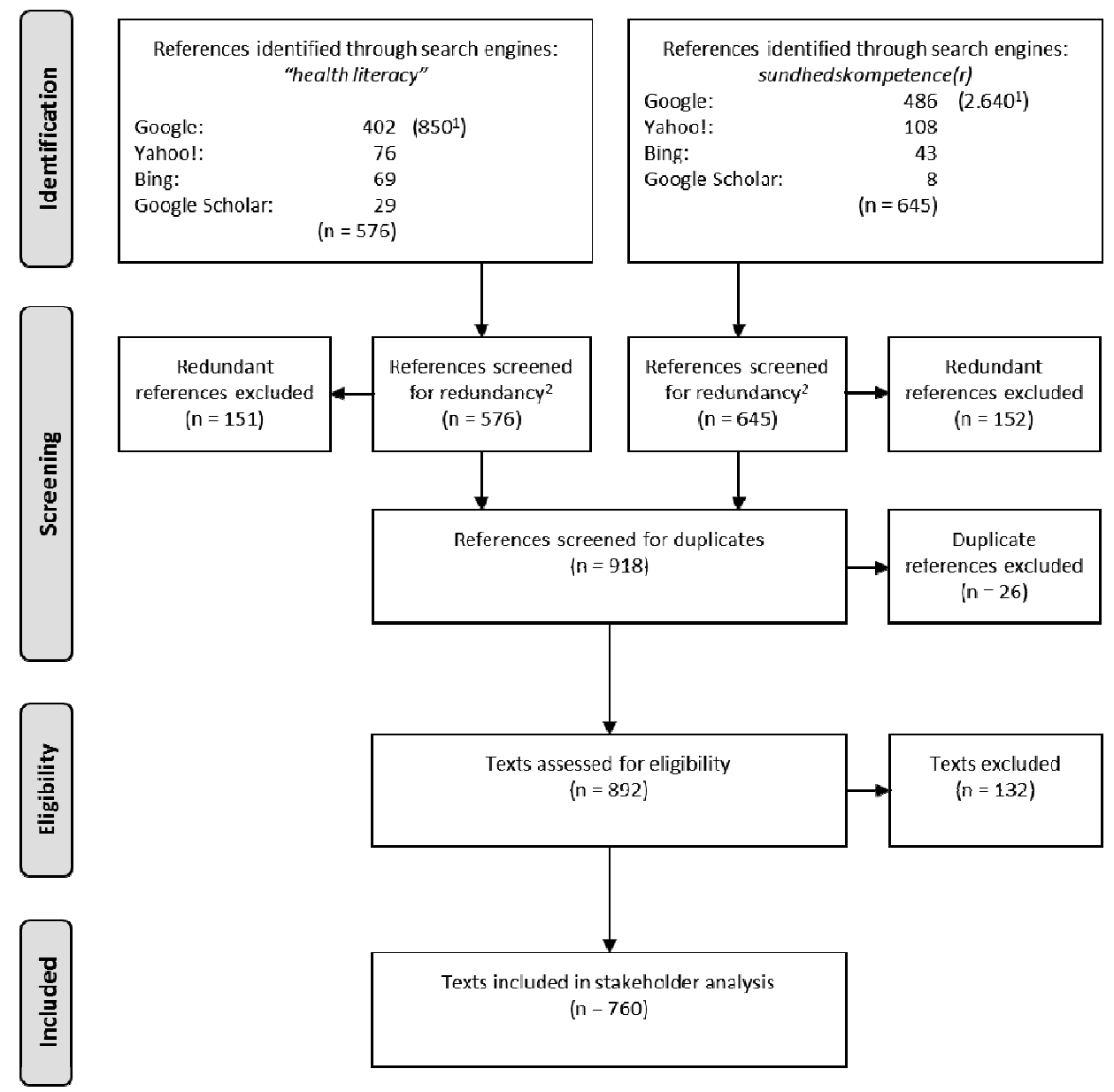

\footnotetext{
$1 \quad$ Without redundancy filter.

Redundancy screening included removal of duplicate reference and references to very similar text, e.g. to print or mobile versions of the same websites.
}

Figure 6.1 Data collection flow diagram

The search results were downloaded and reviewed by two of the authors (KS and ON). All references (hyperlinks) to web-based texts were assessed for inclusion in the final data set in terms of availability (website should be accessible), theme relevance (health literacy included in the text), context relevance (text relevant to Danish context) and redundancy (very similar texts should not be included more than once). Subsequently, the data was scrutinized in a stakeholder analysis grounded in methodological recommendations of Schmeer (Schmeer, n.d.). The analysis constituted the organisational profile, sector profile, health literacy interest, alliances, leadership and power 
characteristics of the stakeholders. A sub-analysis focusing on power and leadership was performed to identify the movers and shakers in the Danish health literacy field. The identified stakeholders were grouped into three categories by the investigators according to their perceived power and influence in terms of the context within which they were appearing in the references included in the data set. The categories entailed 1) those who show leadership and have high powers; 2) those who show leadership and have medium powers and 3 ) those who show no leadership, but have high or medium powers (Schmeer, n.d.).

\section{Results}

A total of 430 references to various forms of web-based texts were included in the final data set. The texts comprised documents such as reports or presentations, book references, personal, organisational, institutional and corporate websites, networks, archives and databases. Figure 6.1 outlines the flow of the search and assessment process. All texts in the final data set were included in the subsequent stakeholder analysis.

\section{Identification of stakeholders in the field of health literacy in Denmark}

The stakeholder analysis yielded a map of all the identified sectors and stakeholders (Figure 6.2). As can be seen, a substantial part of the stakeholders were involved in policy, education and applied research, whereas a smaller number referred to areas such as communication, capacity building, civic engagement and businesses. In addition, only a marginal amount of stakeholders belonged to healthcare services. The results are detailed in the following.

The policy arena was dominated by stakeholders such as municipalities and the regions, who applied the concept in guidelines and local interventions as part of their responsibility for prevention and promotion. A substantial amount referred directly and indirectly to a specific report on competency made by the Ministry of Education (Undervisningsministeriet, 2005). While at national levels the Ministry for Foreign Affairs and the Ministry for Food, Agriculture and Fisheries were associated with a few texts, there were no references to the Ministry of Health. However, a substantial number of texts referred to the Danish Health and Medicines Authority (Sundhedsstyrelsen) and the above-mentioned status report from 2009 on health literacy (Madsen et al., 2009). Furthermore, a considerably part of the results was associated with European stakeholders such as the European Commission, the European Parliament and the European Centre for Disease Prevention and Control. 
The educational arena included stakeholders such as primary schools, secondary schools, university colleges, universities and institutions working on lifelong learning. The texts concerned mostly the specific competency report from the Ministry of Education (Undervisningsministeriet, 2005). In the tertiary educational institutions the data referred to curriculum that included focus on health literacy such as university college programmes for nurses as well as dental, social and healthcare assistants along. At university level a small amount of data referred to the curriculum related to information technology and the dental degree programme; however, references related to public health and medical curriculum did not appear in the data set. In contrast, lifelong learning was represented by a substantial amount of results referring to regional and local centres for adult education.

The research arena was represented by all five universities in Denmark and a number of university colleges and national research institutions. However, it was apparent that research was anchored among only a small number of people or research groups. The research context varied from competency, nutrition and obesity, healthcare, patient safety and education and immigrant medicine to health promotion. Additionally, innovation platforms and portals related to e-health were identified.

The communication arena included data related to media in all forms such as national and local newsletters, television, web-fora and blogs. In addition, some texts referred to networks such as the Healthy Cities Network in Denmark and the newly established Nordic Network on Health Literacy.

The arena for capacity building was characterized by stakeholders such as the trade unions for doctors, nurses, physiotherapists and engineers and societies and communities for professionals, for example the Danish Society of Public Health. A number of links referred to personal profiles within social networks such as LinkedIn and staff profiles at research institutions, where health literacy formed part of professional interest and work areas. Furthermore, a few job banks were identified announcing job descriptions that included a focus on health literacy. 


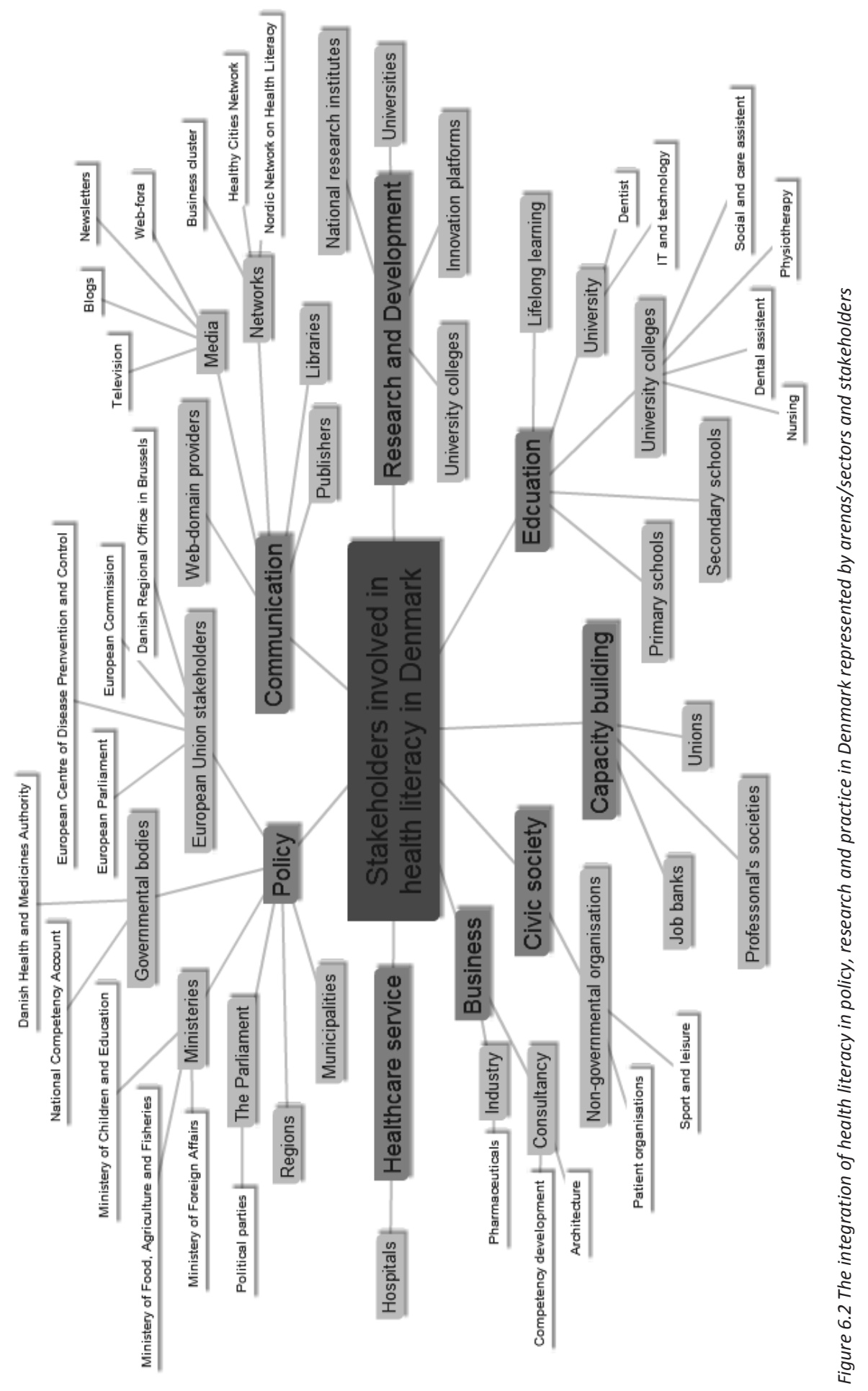


The arena of civic engagement was displayed by non-governmental organisations with a majority being patient organisations representing a variety of diseases and conditions such as mental disorders, rare diseases, cancer, pain and obesity. A small subset included organisations involved in leisure, sport and sponsorships. A few texts referred to individuals discussing the importance of health literacy on their personal websites.

The business arena concerned a few texts referring to the pharmaceutical industry and to a couple of small consultancies promoting personal development and capacity building in terms of health literacy and competency. A couple of texts were associated to architects involved in designing and building primary health centres.

Finally, the healthcare service arena included a few hospitals with texts concerning quality of care, immigrant health, patient education, adherence and compliance.

\section{Identification of movers and shakers in terms of power and leadership potential}

Although a variety of stakeholders were identified, almost no interconnections or alliances could be traced apart from a considerable amount of references to the two reports on competency (primarily texts related to 'sundhedskompetencer') and health literacy (primarily texts related to health literacy) and to the Healthy Cities Network in which a conference was organised in 2011 with a focus on health literacy. Therefore, we assessed that no stakeholders qualified to the first group of those who show leadership and have high powers and only the Healthy Cities Network qualified in principle for the second group of those who show leadership and have medium powers. The remaining stakeholders at large were assigned to the third group of those who show no leadership, but have high or medium powers.

The classification was grounded in the observation that, although, the Danish Health and Medicines Authority and the Ministry of Education had both delivered milestone reports on health literacy and "sundhedskompetencer", respectively, it was not detectable that they were actively involved in any follow-up activities with regard to health literacy or "sundhedskompetencer". In addition, while a considerable number of municipalities and regions had inserted 'sundhedskompetencer' in documents on policy, research and practice, the findings did not display to be coherent, consistent or coordinated approaches. The national, legal power structures and authorities such as the parliament and the ministries were only represented by very few references in the data set and in no visible capacity that could qualify for the group with high power or leadership or the group with no leadership and medium power. The stakeholders in research may hold a medium power in terms of agenda-setting, but activities were 
scattered and isolated among the major universities, university colleges and research institutions; no strong, coherent collaboration could be identified. Notably, the hospitals were barely visible in the data and thus could not qualify for the first or second group. The trade unions and the societies for professionals displayed scattered activities such as single standing questions posted by individual members in web-based discussion fora or single presentations at events, hence no strong vision, strategy or activity was presented that could point towards a strategic choice of engagement. While a few schools, university colleges and universities seemed to integrate health literacy as part of their curricula or strategic framework,, no clear pattern could be identified apart from merely reactions and reflections to the report of the Ministry of Education; rather than asserting a proactive role in promoting health literate schools and educational institutions. In addition, non-governmental organisations, the patient associations in particular, were not well represented in the dataset, although they should be recognised for their potential advocacy role as a power of influence. The forprofit businesses represented in the study did not appear as strong leaders, since they seemed to be either small consultancies or major pharmaceutical companies, mainly involved in well-being at the workplace or quality assurance, which is why they were included within to the third group consisting of those who showed no leadership, but had high or medium powers.

In summary, there was no actor or stakeholder flagging as a clear leader in the Danish health literacy field. Rather, the power and leadership analysis revealed a significant leadership vacuum in spite of a clear power potential to become movers and shakers of the integration of health literacy in research, policy and practice in Denmark.

\section{Discussion}

While population data for the HLS-EU survey was conducted in eight European countries, the Nordic countries were not represented in the data pool (HLS-EU Consortium, 2012a). This, combined with the scarce research in the emerging field of health literacy in Denmark, suggested the need for a complementary study. Hence, web-based data was generated from three search engines using the terms "health literacy" and "sundhedskompetence" followed by an analysis to identify stakeholders as well as the potential movers and shakers that influence the integration of health literacy in Denmark.

Generally, the findings revealed that a variety of sectors were engaged in the health literacy field such as policy, research, education, capacity building, healthcare, business and civic society with various stakeholders. These results respond to the 
broad view on health literacy presented by Kickbusch and Maag, who define health literacy as "the capacity to make sound decisions in the context of everyday life - at home, in the community, at the workplace, in the health-care system, in the market plac, and in the political arena" (Kickbusch \& Maag, 2008). Unpredictably, the role of the health service sector and health authorities were almost invisible apart from the health literacy review conducted in 2009. This appears in strong contrast to developments in other countries where actors in the healthcare sector have been the primary drivers of health literacy dissemination and valorisation (Adams et al., 2009; Ishikawa \& Yano, 2008; Paasche-Orlow et al., 2005b).

In general, the health literacy activities appeared as isolated, scattered and with low impact suggesting that the concept of health literacy has yet to be mainstreamed and manifested in Danish research, policy and practice. Furthermore, the subsequent power and leadership analysis showed a clear leadership vacuum in spite of several actors asserting the power to be potential change agents in advancing health literacy in Denmark. Essentially, these findings can be associated to the theory of diffusion of innovation by Rogers, which maps out the stages of agenda-setting, matching, redefining/restructuring, clarifying and routinizing (Rogers, 2003). In this respect, the current study proposes that health literacy has only reached the first step in terms of agendasetting and the question of matching has rarely begun. Hence, health literacy or 'sundhedskompetencer' as a new idea has not yet been anchored in the general health discourse; and the diffusion of health literacy can be regarded only in its infancy in Denmark.

However, it is also evident that so far, the health literacy agenda was influenced by three inducers: the status report on health literacy from the Danish Health and Medicines Authority (health literacy); the competency report of the Ministry of Education (sundhedskompetence), and from other countries or European institutions. Reviewing the report from the Ministry of Education in details, the Danish term 'sundhedskompetence' is linked to 'action competences', which is a term associated to the Danish health educational discourse (Kamper-Jørgensen, Almind, \& Jensen, 2010). In contrast, the term 'health literacy' assessed in the report of the Danish Health and Medicines Authority refers to the international health and educational discourse, in which the English term 'health literacy' is embedded. The international links are in general aligning with the international discourse referenced in the status report of the Danish Health and Medicines Authority; where especially European institutions have played a role in knowledge transfer. 
Table 6.3 Results of the power and leadership analysis: who is important for the advancement of health literacy in Denmark

\begin{tabular}{ll}
\hline Those who have leadership and high power & Not available \\
\hline Those who have leadership and medium power & The Healthy Cities Network \\
\hline Those who do not have leadership but have high to & Policy advisory boards on health and competency \\
medium power & Parliament \\
Ministries & Regions \\
Municipalities \\
Research institutions \\
Healthcare service providers \\
Trade unions \\
Societies for professionals \\
Schools, university colleges and universities \\
Non-governmental organisations \\
Businesses
\end{tabular}

\section{Limitations}

Initially, a systematic literature review of Danish health literacy research was foreseen. However, as only few references were identified in health related scientific databases (see box 1 ) the more feasible choice was to utilise common Internet search engines. A limitation of this approach is the risk of the data collection being biased by the intransparency of the ever-changing search engine algorithms. The effect was sought to be minimized by working with downloaded data as opposed to going through the search results online which otherwise would induce risk of a changing data set. Further, we have described the settings used when searching to increase transparency for our part. This will enable others to conduct similar searches; however, as emphasised, probably not with a perfect match at another point in time.

To reduce the bias of the unknown coverage of common Internet search engines, we conducted the searches in three different search engines. More could have been included; however, we experienced a great overlap of the search results in the three chosen. Two of the more specialised databases indexing research and other literature originating from Denmark: forskningsdatabasen (records from all Danish universities and a number of Danish research institutions) and bibliotek.dk (database of Danish libraries' holdings) are both covered by one or more of the used search engines. Further research should preferably build on primary sources, rather than secondary sources only and explore the content, the interests and the power relations by e.g. indepth interviews to validate the present work. 


\section{Future implications}

In order to determine health literacy in Denmark, the gaps identified in the findings of the current study, should be bridged. Thus, it is proposed that future work should include:

- assessing the term health literacy in terms of coherent application in Danish research, policy and practice;

- measuring health literacy in the Danish population;

- including health literacy in all health-related educations;

- developing a national health literacy strategy that can enhance stakeholder involvement in research, policy, and practice;

- improving Danish, Nordic, European and global networking to learn from best practices and current research.

An increased focus on health literacy is expected to qualify healthcare, disease prevention and health promotion at individual as well as societal level for the benefit of population health. However, it will require not only the profound interest in health literacy from stakeholders involved, but also the legitimacy, power, priority and leadership to change the current status quo.

\section{Authors' contribution}

KS and ON have contributed to the introduction, methods, results and discussion, HTM and $\mathrm{HB}$ have contributed to the introducition and discussion. 
Knowing is not enough - We must apply

Willing is not enough - We must do.

Goethe 


\section{CHAPTER 7}

\section{Health literacy - a catalyst for knowledge transfer}

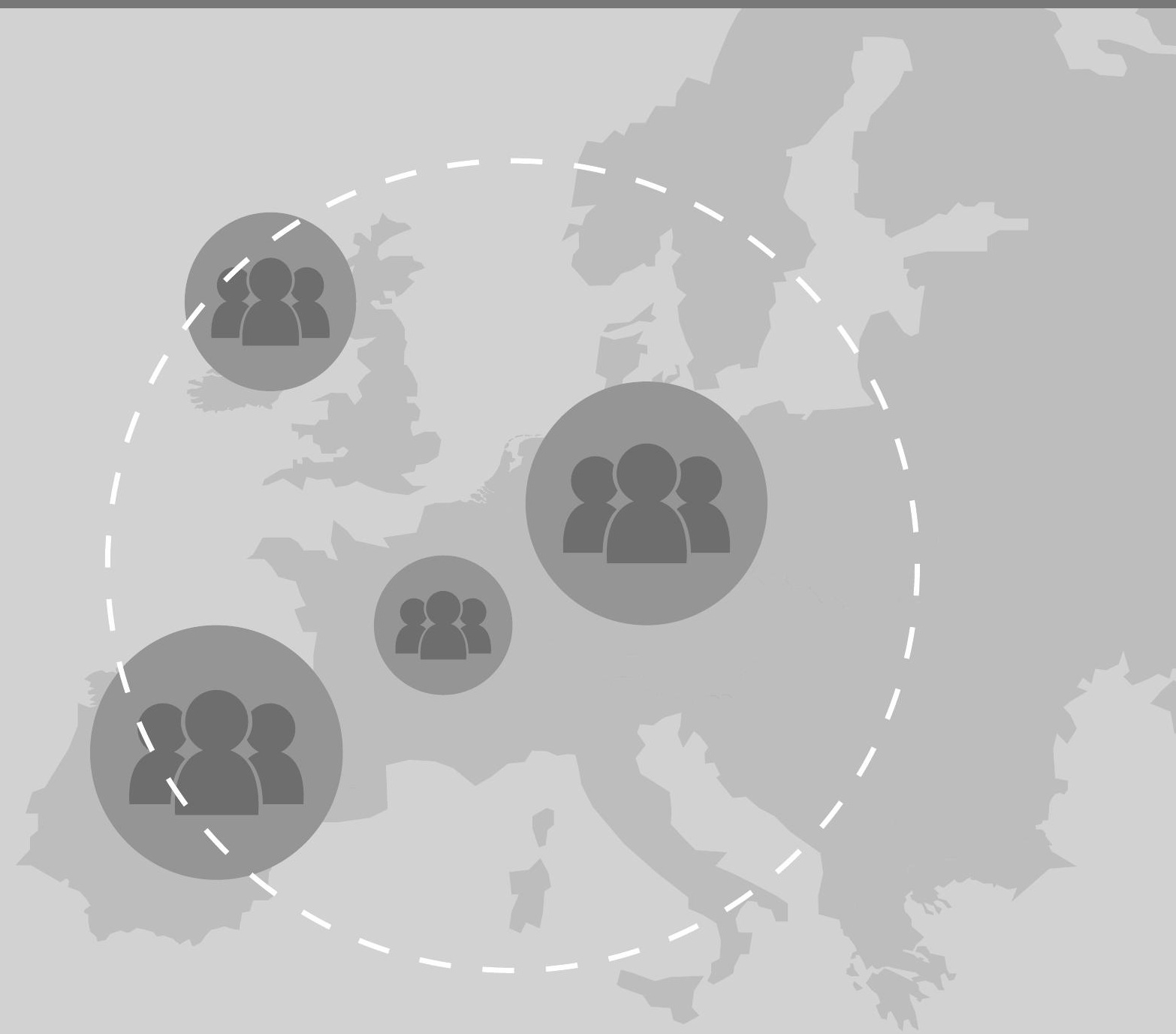




\section{Abstract}

The complexity and novelty of public health genomics poses a challenge to ensure effective and responsible translation of genome-based information to the benefit of population health. The aim of this article is to provide a literature-based insight on how the concept of health literacy can act as a catalyst to the translation process and comment on the necessity to adapt new perspectives in a rapid changing world such as the health-literacy friendly approach of e.g. Google. Taking advantage of the potential of health literacy in the population along with a recognised role for health professionals as knowledge-brokers; being "nudges" will benefit the efficiency and responsibility of translating genome-based knowledge. 


\section{Introduction}

$\mathrm{P}$ ublic health genomics as well as health literacy are emerging areas of interest for research and policy development. The intersection of the genetics era and the information age provide unique and daunting challenges for health consumers who may not have the health literacy to keep pace (J. Johnson, Case, Andrews, \& Allard, 2005). The complexity of genomics in itself imposes a challenge of translation of genomic discoveries to appropriate health applications. Public health genomics representing a multi-disciplinary field concerns the responsible and effective translation of genome-based knowledge and technologies for the benefit of population health (Burke, Khoury, Stewart, \& Zimmern, 2006). It assesses the impact of genes and their interaction with behavior, diet and the environment on the population's health (Nielsen-Bohlman et al., 2004). Public health genomics encounter challenges on how to responsibly and timely translate genome based information into policies and practice; tackling risks and benefits of genetic developments, searching for the balance between provision of strong protection of individual's interests and needs while enabling society to benefit from the genomic advances and empowering individuals (Brand \& Brand, 2007).

Health literacy represents the cognitive and social skills which determine the motivation and ability of individuals to gain access to, understand and use information in ways which promote and maintain good health (Nutbeam, 1998). Health literacy is context and content specific and involves the competences to access, understand, appraise and apply information to make health decisions in everyday life throughout the life span (Sorensen, Van den Broucke, et al., 2012). The health decisions could entail cure and care, disease prevention and health promotion in all its aspects; thus also including decisions concerning genomics. Though traditionally health literacy has been operationalized as an individual-level construct, it can also be viewed in a public health perspective as 'public health literacy' taking into account the complex social, ecological and systemic forces affecting health and well-being (Freedman et al., 2009).

Unfortunately, in contrast to the rapid pace of discovery of gene-disease associations for common health conditions, research to understand the clinical potential of these findings has lagged (Wade, McBride, Kardia, \& Brody, 2010). Advances in genomics have led to mounting expectations in terms of their impact on healthcare and disease prevention, but the challenge remains on how to move human genome discoveries into health practice in a way that maximizes health benefits and minimizes harm to individuals and populations (Khoury et al., 2007). An effective catalyst to this process could be health literacy, which plays a critical role in turning information into knowledge, decision-making and action stimuli, and in this paper it is hence argued 
that the aspect of health literacy is essential when aiming for responsible and effective translation of genome-based information to the benefit of the population health.

\section{"Lost in translation" - Challenges of translating genome-based knowledge}

We are lost in translation. "Enormous amounts of new knowledge are barreling down the information highway, but they are not arriving at the doorsteps of our patients" (Lenfant, p. 873) (Lenfant, 2003). Giving an indication of the complexity, Khoury and colleagues describe four translational phases of genome-based research. The first phase (T1) seeks to move genome-based discoveries into a candidate health application. The second phase (T2) assesses the value of the genomic application for health practice leading to the development of evidence-based guidelines. The third phase (T3) attempts to move the evidence-based guidelines into health practice, through delivery, dissemination and diffusion research. The fourth phase (T4) concerns the populationlevel evaluation of genomic applications in practice (Khoury et al., 2007). Every stage involves scientific communication to professionals as well as lay people and the complexity of the matter poses an important challenge for the translation process of disseminating information to create knowledge and stimulate action. A gap in knowledge can slow down appropriate use of e.g. genetic susceptibility testing and fail to deter the premature application of tests that have little clinical utility (Wade et al., 2010). Scientific communication is hence a challenge, and often, public health professionals disseminates messages as grounded in the theories and principles of health education such as what the message says or health communication concerning how the message is delivered, rather than considering the health literacy of the intended audience such as whether the message is accessed and understood (Gazmararian, Curran, Parker, Bernhardt, \& DeBuono, 2005a). Most of our major life problems are associated with lack of knowledge, skills or ability to assess risks. Traditional methods of providing content through mass communication cannot keep pace and therefore a strategy is needed that does not rely on perishable content, but instead, helps people gain lifelong skills to find and assess genetic information on their own (J. Johnson et al., 2005).

The information era has made its impact on everyone's life. In fact, information is now reaching the patient and shared in groups and networks through the Internet, more rapid than ever. Health questions are not posed to the doctor in first instance, often the Internet is asked first; challenging the role of medicals and public health professionals and their role of experts as knowledge brokers and translators. Information-seeking has become a natural habit for the G-generation, the Google generation (Jarvis, 2009), and the challenge is to see how systems can match the interactivity 
on the internet and use it to accelerate translation of genomic information to the benefit of the population.

\section{Health literacy as a catalyst for efficient and responsible knowledge translation}

The essential life-long skills to find and assess information are embedded in people's health literacy. Health Literacy is according to Kickbusch: "the ability to make sound health decision in the context of everyday life - at home, in the community, at the workplace, the healthcare system, the market place and the political arena. It is a critical empowerment strategy to increase people's control over their health, their ability to seek out information and their ability to take responsibility" (Kickbusch \& Maag, 2008). The concept origins from the US where it first appeared in 1974 (Simonds, 1974). American research has shown that limited health literacy affects people of all ages, races, incomes, and education levels and the impact of limited health literacy disproportionately affects lower socioeconomic and minority groups. It affects people's ability to search for and use health information, adopt healthy behaviours and act on important public health alerts. Limited health literacy is also associated with worse health outcomes and higher costs (Berkman, 2004). The newly released American "National Action Plan to Improve Health Literacy" seeks to engage organizations, professionals, policymakers, communities, individuals and families in a linked, multi-sector effort to improve health literacy. The plan builds on the two principles that (1) everyone has the right to health information that helps them make informed decisions and (2) health services should be delivered in ways that are understandable and beneficial to health, longevity and quality of life. The vision of the plan includes a society providing everyone with access to accurate and actionable health information, delivering person-centered health information and services, and supporting lifelong learning and skills to promote good health (U.S. Department of Health and Human Services., 2010).

In Europe, the consortium of the European Health Literacy project defines four dimensions of health literacy: accessing (1), understanding (2), appraising (3) and applying (4) information in all forms to make health decisions in everyday life throughout the life span (Sorensen, Van den Broucke, et al., 2012). The ability to access and obtain information requires the provision of information from institutes and researchers in a form which makes it easy understandable. Health literacy is closely linked to literacy (Nutbeam, 2000a) and information should be communicated in plain language to ensure readability. It is of importance that the messages are conveyed in ways which people can cognitively comprehend. Mostly numeracy plays a crucial role as well in terms of e.g. accessing health risks and therefore numeracy is of equal importance to 
take into account when designing e.g. genome-related communication. Recommended techniques include simplification, clear formatting, omission of distracting information, appropriate framing, use of visuals and confirmation (Apter et al., 2008). Health literacy is also related to the concept of Health Information Seeking Behavior (HISB) (Cutilli, 2010). Longo's “Expanded conceptual model of health information seeking behaviors and the use of information for healthcare decisions" examines the variables (contextual and personal) that influence information seeking and information use, including health status, healthcare structure and care delivery, personal relevance and information environment factors (contextual) and demographic, socio-economic factors, personal and health history, genetics, education, culture, language, attitudes, and current health status as examples of personal variables (Longo, 2005). It is suggested that there are information seekers (monitors) and non-information seekers (blunters); hence some may be identified as more reluctant to search for information whilst others are actively practicing health orientation (Cutilli, 2010).

After a long period of time using mostly mass media campaigns telling people what to do, the reflexivity of people is often underestimated by medical and public health professionals. The appraising component of health literacy is essential when respecting the empowerment aspect of health literacy and the ability of people to take responsibility for their own health. For people to judge the relevance of the health information, it requires a setting for informed choices of e.g. genome-related applications and a demand for effective and responsible translation of knowledge in terms of public health genomics. However empirical evidence also indicates that some people do not want to explore psychosocial issues, do not want to know every detail of disease and treatment and rather leave decisions with their healthcare providers and stay passive (De Haes, 2006). This balance of on one hand practice patient-centered communication i.e. 1) eliciting the patients' perspective, 2) understanding the unique psychosocial context, 3) reaching a shared understanding concordant with the patients' values and 4) helping patients to share power and on the other hand, respect that patient-centered care is not so much about eliciting the patients' perspective and engaging them actively, but rather about respecting the patients' needs and values is discussed by de Haes (De Haes, 2006). The fourth dimension of health literacy relating to applying information refers to the ability to apply the information to one's own health situation and daily life stimulating the motivation for change; if needed. Motivation and activation are inseparable aspects of health literacy, though often overlooked. The actual outcome, the action, is affected by many other physical and socio-economic indicators and though motivated and informed, it may still be that a person is not able to implement a choice or wish. An individual's personal, cognitive and social skills play a crucial role in health literacy but are subject to influences well outside of the control of health professionals and the health system (Peerson \& Saunders, 2009). 
Health literacy can be seen as a catalyst, as an accelerator, to increase the rate and the outcome of the translation of genome-based knowledge. A catalyst is in chemical terms a substance that increases the rate of a chemical reaction without itself suffering any permanent chemical change; it can also refer to a person or a thing that causes a change (Collins English Dictionary, 2003). When the prism of health literacy is taking into account the accessibility of information can open doors to a better understanding of genome-related possibilities and a high level of information can provide better grounds for proper decision-making and possible application of e.g. genome-related tests. In other words, health literacy is the "currency" that an individual needs to access, understand and act on health information. Progress in public health literacy will yield an informed, motivated public with the skills and resources to make positive choices that enhance individual and community health. A skilled professional workforce in healthcare and public health (genomics) can communicate with the public in ways that they understand (Gazmararian et al., 2005a). However, with years of practicing health communication in field of medicine and public health, many professionals still don't succeed to the degree aimed for to the benefit of the population. New perspectives are needed and lessons can be learned from other fields of communication in the favor of health literacy and responsible and efficient translation of knowledge.

\section{New perspectives}

\section{The Google approach}

"It seems as if no company, executive, or institution truly understands how to survive and prosper in the internet age. Except from Google p. 3" (Jarvis, 2009). Google is a company which, in practice, is boosting people's health literacy skills by making access to information easy, by making information easy to find and identify and making information available for comparison and appraisal. Furthermore it makes information easy applicable for personal use. Hence as an eminent knowledge broker Google is an example to learn from, when considering how to meet the health knowledge demands of people. Jarvis has studied the enterprise of Google and posed the question: "What Would Google Do?" in terms of meeting the challenges of the information age. Interestingly, he finds that Google represents a new society, built on connections, links, transparency, openness, publicness, listening, trust, wisdom, generosity, efficiency, markets, niches, platforms, networks, speed and abundance. The Google generation and its world view will change how people see and interact with the world and how business, government and institutions interact with populations (Jarvis, 2009). 
- It brings elegant organization. With its mission to organize the world's information, Google helps people to organize their searches, documents, maps and more. The key is that Google doesn't try to organize people, but provides a platform where people can organize themselves.

- It facilitates connection. People are using the internet's connecting tissue to leap over borders, reorganizing social order, sharing and sorting knowledge and behavior, communicating and coming together in an instant.

- It facilitates niches, overruling "mass" way of thinking. One size does not fit all, also not in health and Google makes it easy to find the way to identify the few who have common interests and direct tailor made offers to their needs.

- It gives answers with a speed unheard of in earlier generations.

- It goes live and makes the internet interactive, person-to-person, overruling distances and tearing down information barriers.

- It is simple. It is powerful. The Google User Experience Team aims "to create designs that are useful, fast, simple, engaging, innovative, universal, profitable, beautiful, trustworthy and personable" p.115.

Striving to facilitate efficient translation of information in a more health literacy friendly way the option is hence to mirror the Google way of work and make designs and applications that are "useful, fast, simple, engaging, innovative, universal, profitable, beautiful, trustworthy and personable". To facilitate responsible translation of information the aspect of data confidentiality should be added to the above lists of essentials.

\section{Implementation of the new perspectives}

One way of implementation is to make communication more health literacy adequate in all phases of the translation process (T1-T4) to facilitate the information stream running more fast, smoothly and accurately in terms of accessibility, understandability, appraisal and applicability. Another way is to recognize and accept the role for medical and health professionals as trustworthy knowledge brokers. They ought to recognize themselves as "choice architects", attempting to move people in directions that will make their lives better, so called "nudges". A nudge is any aspect of the choice architecture that alters people's behavior in a predictable way without forbidding any options or significantly changing their economic incentives. In terms of genome-related information people may have a difficult time predicting how their choices will end up affecting their lives; they have less to gain by numerous options and perhaps even by choosing for themselves. A nudge might be welcomed in this instance (Taler \& 
Sunstein, 2008). As Boccia explains: "Even though the day when the genome is a regular part of the medical record, and the day when personalized medicine will be a reality rather than a catchphrase seems to be still very distant, public health professionals and policymakers in the next decade would do well to prepare the society as well as to prevent misleading claims and clarify the conditions under which the genomic advances can be translated into public health benefits" (Boccia, Brand, Brand, \& Ricciardi, 2009). Thaler and Sunstein advocate for nudging and choice-architecture as a new movement called "libertarian paternalism". "Libertarian paternalism is a relative weak, soft, and nonintrusive type of paternalism because choices are not blocked, fenced off, or significantly burdened. If people want to smoke cigarettes, to eat a lot of candy, to choose an unsuitable healthcare plan or to fail to save for retirement, libertarian paternalists will not force them to do otherwise - or even make things hard for them. Still, the approach we recommend does count as paternalistic, because private and public choice architects are not merely trying to track or to implement people's anticipated choices. Rather, they are self-consciously attempting to move people in directions that will make their lives better. They nudge" (Taler \& Sunstein, 2008) p.6. This means that health professionals help qualify the choices people have and they are not to interfere in the decision-making process. In terms of health literacy the nudging is to ensure accessibility and understandability of relevant choices and information, whereas the appraisal and application steps are the responsibility of the people; employing the freedom of choice.

A third option is to consider the organization and management of the field of public health genomics in order to simplify the access to genome-based tools and knowledge. Networks should be enhanced bringing experts and lay-people together to ensure a rapid exchange of experiences in practice for researchers and policy-makers to act on; and to tackle the evidence dilemma in genomics and personalized medicine (Khoury, 2010). There is a growing recognition for the need of greater public and stakeholder engagement in science policy, a democratization process of creating institutions and practices that fully incorporate principles of accessibility, transparency and accountability. However, in the most controversial fields, there may be no social consensus. In this case the challenge will be to facilitate a respectful and considered debate among stakeholder communities (and especially experts), to reach compromise without escalating hype (Bubela, 2006). An example is Rosenkötter and colleagues' (Rosenkotter et al., 2011) assessment of different tools such as health technology assessment (HTA) and health impact assessment (HIA) to explore the possibilities for evidence guidelines and cooperation to enhance the translation of genome-based health applications for public health practice, as these tools have in common the potential to inform and further the public dialogue and participation (Burton, Adams, Bunton, \& Schröder-Bäck, 2009) 


\section{Conclusion}

The challenge of responsible and effective translation of genome-based information is linked to its complexity and its novelty. Using the catalyst of health literacy yields a synthesis where the translation phases can be accelerated by taking into account the accessibility, the understandability, the appraisal and application of genomic information and communication to match the needs within different population groups. New perspectives are needed to advance and lessons can be learned from other fields such as in the example of Google, which provides a powerful health literacy friendly electronic environment facilitating self-management, simplicity and user-centered applications. Due to the rapid developments and vast amount of information; the roles of health professionals as knowledge brokers are as equally important as using and boosting the potential of health literacy embedded in the population. By actively serving as "nudges" or "choice-architects", public health (genomic) experts can contribute to the efficient and responsible translation of genome-based information to the benefit of population health.

\section{Authors' contribution}

KS and HB have both contributed to the ideas presented in this article. 


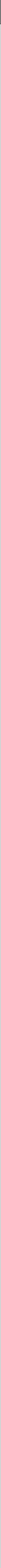


The worst possible outlook is indifference that says: I can't do anything about it; I'll just get by. Behaving like that deprives you ofone of the essentials of being human: the capacity and the freedom to feel outraged. That freedom is indispensable, as is the political involvement that goes with it.

Stéphane Hessel; Indignez-vous! 


\section{CHAPTER 8}

\section{Health literacy -}

a strategic asset for corporate social responsibility

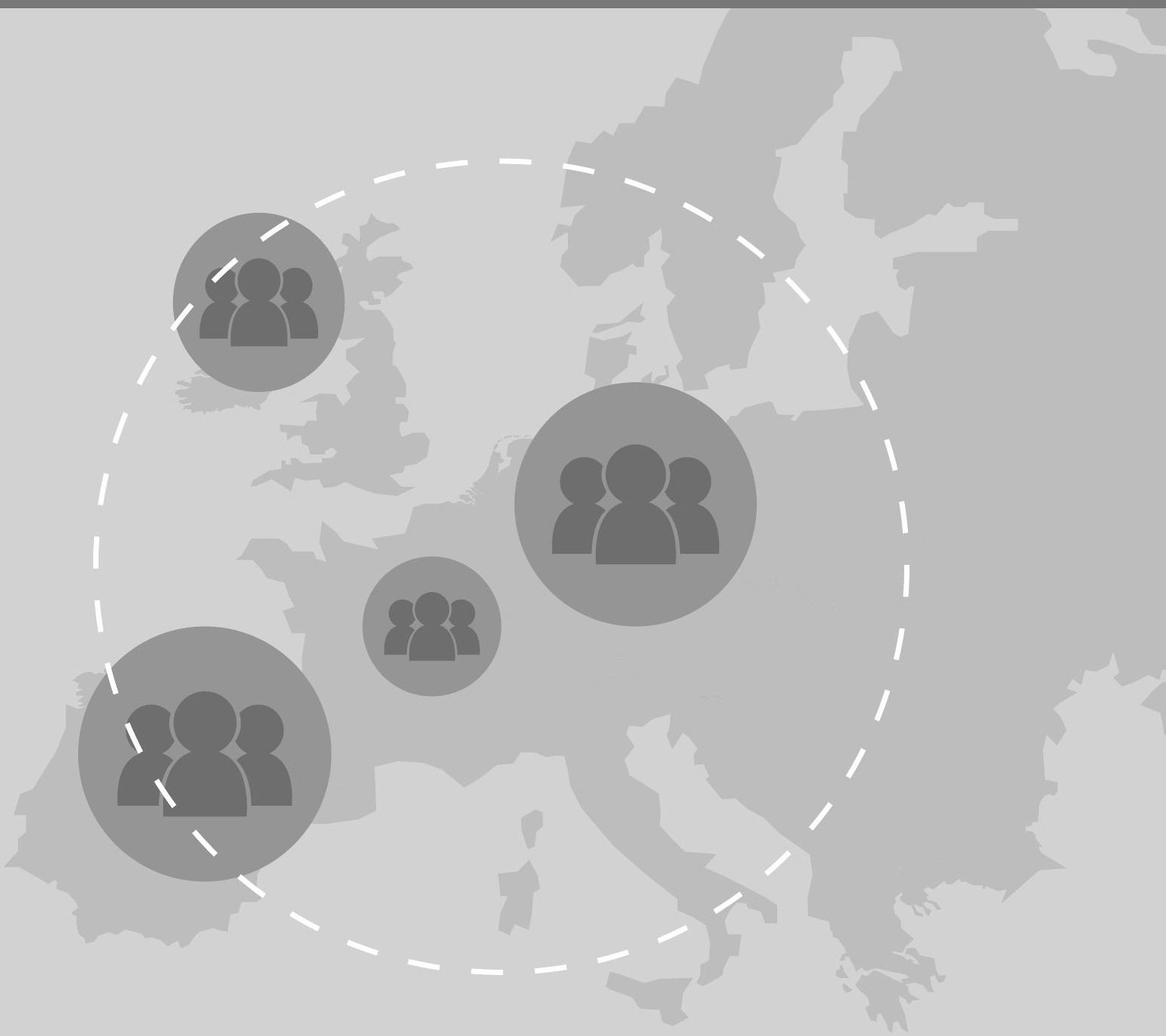




\begin{abstract}
The European Commission (EU) has launched a strategy: 'Europe 2020' aimed to turn the EU into a smart, sustainable and inclusive economy, delivering high levels of employment, productivity and social cohesion. A prerequisite for the success of Europe 2020 is the availability of a healthy population and by this a healthy work force. An action highlighted is raising corporate social responsibility (CSR). The aim of this paper is to present how health literacy can become a strategic asset in CSR through the introduction of the Collaborative Venture on Health Literacy and the development of a business case on health literacy meeting targets of Europe 2020. A scope study revealed that a majority of companies within the network of CSR Europe show already health related employee programs on their corporate websites, but only a few are focused specifically on advancing health literacy. The gap leaves potential opportunities for interventions based on research and good practices, where businesses through CSR can create a health-friendly environment and stimulate the workforce to manage own health, seek information and take decisions in terms of promoting health and well-being, thereby transforming information into knowledge giving grounds for increased awareness among employees.
\end{abstract}




\section{Introduction}

T

he European Commission (EU) has launched a vision of Europe's social market economy for the $21^{\text {st }}$ century called 'Europe 2020 ' as a response to the fact that Europe faces a moment of transformation due to the economic crises. The strategy is aimed to turn the EU into a smart, sustainable and inclusive economy delivering high levels of employment, productivity and social cohesion.

The targets to be reached by 2020 entail an enlarged workforce between 20-64 years old; more investment in innovation, research and development; a sustainable climate and energy strategy; a decrease in the share of early school leavers as well as an increase in the share of the population having a tertiary degree and 20 million less people should be risk of poverty. The targets are representative of the three priorities of smart, sustainable and inclusive growth but they are not exhaustive: a wide range of actions at national, European and international levels will be necessary to underpin them (European Commission, 2010).

\section{Healthy population, healthy work force}

A prerequisite for the success of the Europe 2020 strategy is the availability of a healthy population and by this a healthy work force. Improving access to health and healthcare, combating poverty and social exclusion and reducing (health) inequalities are all means to ensure that everybody can benefit from growth according to the strategy. Furthermore it is of importance meeting the challenge of promoting a healthy and active ageing population to allow for social cohesion and higher productivity (European Commission, 2010) and tackling the demographic change where the working-age population has start to decline as of 2010 , and is projected to drop by $15 \%$ by 2060 within the EU (European Commission, 2008). The challenges concerning occupational health, global markets and demographic change in a European perspective is discussed in detail by Froneberg (Froneberg, 2005, 2007). The European Commission (European Commission, 2010) recognizes that actions are needed in terms of modernization, strengthening of employment, revision of education and training policies as well as social protection systems by increasing labor participation and reducing structural unemployment,and corporate social responsibility among businesses should raise. 


\section{Corporate social responsibility and health literacy}

An action highlighted in the strategy is therefore to renew the EU strategy promoting Corporate Social Responsibility (CSR) as a key element in ensuring long term employee and consumer trust. According to the European Commission, CSR is a concept whereby companies integrate social and environmental concerns in their business operations and in their interaction with their stakeholders on a voluntary basis (European Commision, 2006). A more comprehensive definition states that CSR entails economic, legal, ethical and discretionary or philanthropic expectations that society has of organizations at a given point in time (Visser, Matten, Pohl, \& Tolhurst, 2007). The reasons for companies to engage in CSR are threefold: it curries favor with customers, it encourages employee loyalty and goodwill and it attracts investors (Portney, 2008). CSR can make a significant contribution towards sustainability and competitiveness (European Commision, 2006) and according to CSR Europe, the leading European business network for corporate social responsibility, the Europe 2020 strategy constitutes a unique platform to further develop CSR as a strategic tool for sustainable global economy (CSR Europe, 2010).

To meet the health priorities incorporated in Europe 2020 such as making the workplace more user-friendly for the 50 + populations, addressing inequalities, promoting a sustainable workforce for health, encouraging capacity building and better eHealth integration (Boehm, 2010), the notion of health literacy is appropriate to emphasize. Health literacy is defined by Kickbusch, Wait, Maag, \& Banks (Kickbusch et al., 2005) as the ability to make sound health decisions in the context of everyday life at home, in the community, at the work place, the healthcare system, the market place and the political arena. It is a critical empowerment strategy to increase people's control over their health, their ability to seek out information and their ability to take responsibility. The field of health literacy is growing rapidly involving now a large and interdisciplinary audience (Berkman, Davis, \& McCormack, 2010). As a topic on the European health agenda health literacy is included in the white paper 'Together for Health: A Strategic Approach for the EU 2008-2013', where it is closely linked to the core value of citizen's empowerment, participation, influence on decision-making as well as the competences needed for well-being and health in the perspective of lifelong learning (European Commission, 2007). As part of the strategy a health literacy survey is performed to measure the scope of health literacy in the European population (HLS-EU Consortium, 2008).

This paper aims to present how health literacy can become a strategic asset in conjunction with CSR by highlighting the Joint Venture on Health Literacy and discuss its relevance in terms of meeting the targets set out in Europe 2020. 


\section{Health literacy as an asset for corporate social responsibility}

Linking corporate social responsibility with health literacy means making an appeal to address both business engagement and civic engagement in health, thus a reciprocal responsibility of creating more health-literate friendly workplaces and of employees obtaining basic knowledge and information needed to understand and take action on individual and public health concerns. For health literacy to progress, partnerships, both traditional and new, must marshal necessary resources (Freedman et al., 2009) and introducing it as an asset for corporate social responsibility can widen these opportunities.

In this respect a new CSR initiative has been launched under the organizational umbrella of CSR Europe. The Collaborating Venture "Health Literacy: Improving health knowledge among our employees and our communities" from 2010 is a two year project with a steering group of corporate leaders from MSD, Nestlé and Microsoft and Maastricht University as stakeholder leader (CSR Europe, 2011). Recognizing that health literacy is of importance in terms of health at work and of importance to meet the targets of the EU 2020 the collaborative venture aims to explore how businesses can actively contribute to improving health literacy in Europe through CSR by developing a business case on health literacy focusing on

1. integrating health literacy initiatives in existing programs on health and well-being in the workplace;

2. engaging in an active dialogue with key stakeholders to share bestpractices and discuss the best tools, technologies and methodologies to improve and accelerate European citizen's health literacy;

3. developing a "Blueprint for Action in Health Literacy", based on best practices and case-studies. This management tool will help companies devise a framework for prevention, education on healthy choices and managing chronic diseases in the workplace, with a focus on healthy lifestyle, particularly regarding nutrition and physical activities.

As a starting point a scope study has been carried out in spring 2011 among the 75 corporate members of CSR Europe identifying existing health and health literacy activities through a mapping exercise based on data from their corporate websites (Sorensen, Tsflidis, Heel, \& Brand, 2011). The initial results showed that it is common for companies to show health related activities for employees on corporate websites and more than $75 \%$ shared information on health related activities in general and $3 \%$ share information concerning activities dedicated to the advancement of health litera- 
cy. The analysis of activities gives an indication that health is often an integral part of corporate strategy, especially in terms of health protection with references to guidelines, legislation and overall policies concerning safety aspects at work, and less in terms of health promotion and well-being such as health check-ups, coaching and access to fitness, which seem less established and integrated into corporate structures. Concerning specific dimensions of health, the provision of information is taking place to a high degree in many companies, but the steps of ensuring capabilities, opportunities and motivation as agent for change (Michie, Van Stralen, \& West, 2011) in terms of deeper understanding, appraisal and awareness of health is less transparent and developed.

Thus, there is a potential gap, where health literacy in the business context can create value not only for employees, but also for businesses, and the aim of the Collaborating Venture is to explore these opportunities. This initiative is also in line with the World Health Organization (World Health Organisation, 2008) emphasizing that positive environments and better health for workers mean greater efficiency, less sickness and absenteeism, less spending on healthcare, less labor turnover, higher longevity of the workers (less spending on training of fresh workers), avoidance of legal actions and a better corporate image in the society. All of these benefits ultimately lead to better business outcomes and can create a win-win situation for employer and employee. In fact Berry, Mirabito and Baun (Berry, Mirabito, \& Baun, 2010) state that the investment in health and well-being at workplace would result in six dollars saved per one dollar investment. However, not all share the optimism. Holmquist (Holmquist, 2009) argues that health promotion as part of CSR enables corporations to increase their control over their employees' behavioral repertoire into a desired way of acting and may be intimately linked to an idea of social control according to company norms and value, which is not always to the benefit of the employee. Though Europe 2020 fosters the idea of public/private partnerships not all are in favor of the business sector being involved in public health raising concerns that stakeholders such as charities and local governments will be under pressure when campaigns are performed by the industry (Lang \& Rayner, 2010). The notion of CSR itself has been questioned to be of limited use in creating social change, since businesses focus on profit and can't act in any other interest than the interest of the shareholders (Corporate Watch, 2006).

\section{Conclusions}

Modern companies cannot operate without considering the social consequences of their actions. According to Burmeister, CSR is shifting from a defensive strategy, avoid- 
ing a poor reputation and financial risks, to an offensive approach, in which CSR is seen as a means of doing business that creates new products and markets (Burmeister, 2008). Advancing health literacy in companies as a corporate strategic choice can fit the dynamic change of CSR from an add-on to a built-in CSR, where social considerations are integrated into strategy and operations. Furthermore, it can stimulate the shift to value creation instead of value protection with a focus on innovation and competitive advantage instead of focusing only on risk and reputation management. The philanthropic approach of CSR is renewed through the idea of "shared values" introduced by Porter and Kramer (Porter \& Kramer, 2006). In this light the value is the reciprocal responsibility of advancing health literacy and can be seen as beneficial for the individual in terms of better awareness and ability to make sound decisions and for the private sector in terms of a healthier work force. The business sector playing a role in promoting health literacy through occupational health services will likely gain importance due to the economic consequences of lost productivity and the financial burden for medical coverage to employees. Recognizing the major impact the business sector can have to promote health literacy through responsible marketing and health promotion, it is of equal importance to challenge potential conflicts of interest and explore the measures that can be undertaken to avoid such conflicts (Taylor, 2010).

The business case is a recommendation to decision makers to take a course of action for the organization, supported by an analysis of its benefits, costs and risks compared to the realistic alternatives, with an explanation of how it can best be implemented (Gambles, 2009). By making the business case on health literacy, the Collaborating Venture present health literacy as an asset, as a management tool, where businesses through CSR can create a health-friendly environment and stimulate the workforce to manage own health, seek information and take decisions in terms of promoting the health and well-being, thereby transforming information into knowledge giving grounds for increased awareness among employees. Through the showcase of good practices in the Blueprint for Action in Health Literacy and leaning on existing research such as the Cochrane review on health literacy (Services, 2011), health and wellness program design (Berry et al., 2010) as well as the upcoming results of the European Health Literacy Survey evidence-based interventions can be designed to embrace targets for a healthy population including the Europe 2020 benefits of employment, productivity and social cohesion.

\section{Acknowledgements}

The authors are grateful to staff at CSR Europe and all members of the steering group of the Joint Venture on Health Literacy, especially Stéphane Cossandey and Cécile 
Duprez-Naudy, Nestlé, Switzerland_for fruitful feedback and to the European Public Health students Vera van Heel and Benjamin Tsiflidis who conducted the scope study as part of their internship in Department of International Health, Faculty of Health, Medicine and Life Sciences at Maastricht University.

\section{Authors' contributions}

KS and HB developed in partnership the case on health literacy as an asset for corporate social responsibility presented in the paper. 


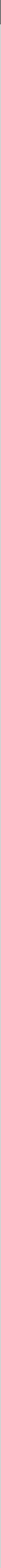


We are coming to understand health not as the absence of disease, but rather as the process by which individuals maintain their sense of coherence (i.g.

sense that life is comprehensible, manageable, and meaning ful) and ability to function in the face of changes in themselves and their relationships with their environment.

Aaron Antonovsky 


\section{CHAPTER 9}

Developing health literate businesses as part of corporate social responsibility

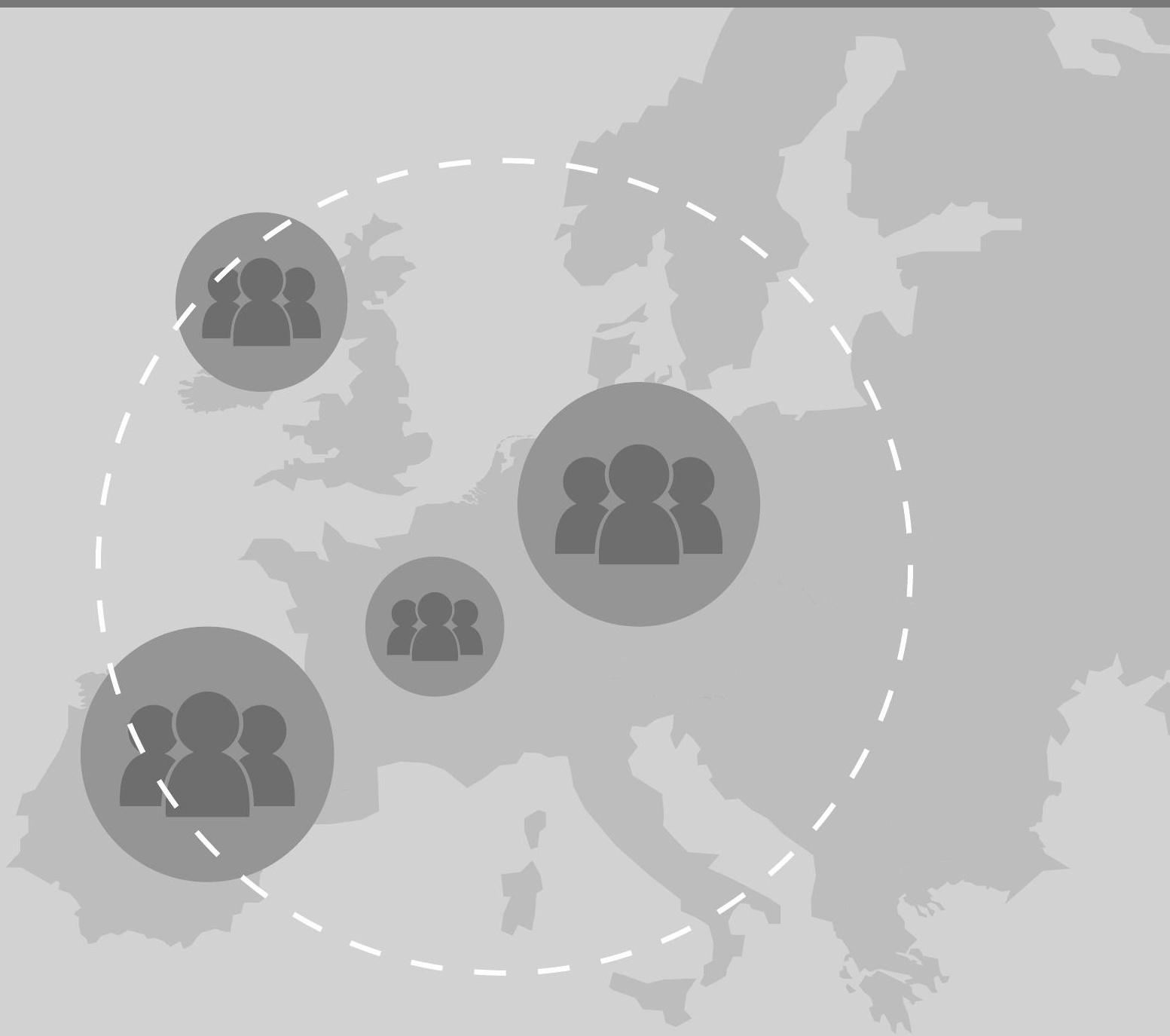




\section{Abstract}

Purpose In recent years, health and healthy living have become increasingly important issues both in society at large and in the workplace. This study aims to explore how multinational companies develop health literacy strategies in the realm of corporate social responsibility to promote health at work and healthy living.

Methods In-depth, semi-structured interviews were made with key staff in 14 multinational companies possessing knowledge on the business' health initiatives and analysed to develop a grounded theory.

Findings The study resulted in a three-tiered theoretical model implying that in order to improve health literacy businesses should make a clear strategic choice and incorporate health at work as a core value. Health programmes should be based on strategic policies and integrated in core business, rather than as independent health projects. The approach should be sustainable and match the needs of employees including health literacy as an explicit target. Health literacy outcomes should be measured and evaluated to follow the progress and ensure a proper fit between actual needs and the efforts undertaken.

Societal implications A mind shift is needed at business level to encourage health literate decisions not only in the fitness room, but also in the boardroom as part of corporate social responsibility.

Originality As only scarce research exists on health literacy and corporate social responsibility, the generated theory provides new perspectives for business actions on health literacy to promote health at work and healthy living. 


\section{Introduction}

\section{$\mathrm{T}$}

he concepts of health literacy and corporate social responsibility (CSR) are emerging areas of action for multiple stakeholders promoting health at work and healthy living (Sorensen \& Brand, 2011a). Recent research indicated that limited health literacy negatively influences health outcomes (Berkman et al., 2011; Paasche-Orlow et al., 2005b) and these findings are supported by the European Health Literacy study (HLS-EU Consortium, 2012a). The study revealed that almost one out of every two individuals exhibits limited health literacy. The wide spread prevalence of limited health literacy has also been described as the 'silent epidemic' (Clark, 2011).

Health literacy is closely linked with human sustainability and the quality of life. It concerns the capacity to make sound health decisions in the context of everyday life at home, in the community, in the workplace, in the healthcare system, in the market place, and in the political arena (Kickbusch \& Maag, 2008). The general concept involves 'peoples' knowledge, motivation and competency to access, understand, appraise and apply information in order to form judgments and make decisions in everyday life in terms of healthcare, disease prevention and health promotion so as to improve the quality of life during the course of life" (Sorensen, Van den Broucke, et al., 2012).

By including health literacy as part of a business' CSR, companies can create health literacy-friendly working environments and support the workforce to become more health literate to mobilize a healthy and sustainable workforce (Sorensen \& Brand, 2011a). The European Commission defines CSR as "the responsibility of enterprises for their impacts on society" (European Commission, 2011). The definition emphasizes the importance of companies initiating a process to integrate social, environmental and ethical human rights and consumer concerns into their business operations and core strategy. It is generally recognized that CSR, at the very least, encompasses human rights, labor and employment practices such as training, diversity, gender equality and employee health and well-being (European Commission, 2011).

Globally and at European level, there is strategic demand for public, private and civil society stakeholders to engage in health and well-being at work to support healthy living such as outlined by the World Economic Forum (WEF): "Workplace health promotion programs can promote healthy behaviors through incentives such as work place health screenings, promoting smoke-free workplaces or by providing healthy food options. Employers benefit from these programs through increased employee productivity, improved corporate image and reduced healthcare costs. At a higher system level, healthy labor implies secure and sustainable employment which significantly impacts the well-being and health of the population" (World Economic Forum prepared in collaboration with Bain \& Company, 2013). According to the World Health 
Organisation (WHO) "Health at work and healthy work environments are among the most valuable assets of individuals, communities and countries. Occupational health contributes positively to work motivation, job satisfaction and to the overall quality of life of individuals and society" (World Health Organisation, 2008). In addition, the European Union (EU), in its Europe 2020 strategy, aims for a smart, sustainable and inclusive economy to deliver high levels of employment, productivity and social cohesion for the current and future generations to continue enjoying a high-quality of health life (European Commission, 2010). In this regard, the WEF emphasizes that "education and communication are important to build health literacy and strengthen the populationlevel knowledge on the links between everyday behaviors and health" (World Economic Forum prepared in collaboration with Bain \& Company, 2013).

However, healthy living is influenced and challenged by several global megatrends such as demographic change decreasing the workforce, an increase in noncommunicable diseases as well as socio-economic inequalities (World Economic Forum prepared in collaboration with Bain \& Company, 2013). In addition to these extrinsic factors, fundamental challenges in the workplace itself such as: 1) the continuing distribution of organizations; 2 ) the availability of enabling technologies and social collaboration tools; 3 ) the upcoming shortage of knowledgeable workers; 4) the demand for work flexibility and 5) pressure for more sustainable organizations and work styles (Ouye, 2011) affect health at work. In turn, these demands require new and innovative ways of thinking concerning 'workplaces of tomorrow' (Deloitte, 2009). Although an employee with few health risks spends less money on medical care due to fewer chronic illnesses and avoided serious health events; many employers still consider poor employee health to be a fringe issue, not a true business issue (Lynch, 2002). Yet, the medical costs are not the primary outcome of poor health, because healthy employees not only cost less in medical care, they are also more functional at work, absent less often, experience fewer injuries and arrive back on the job more quickly after they do get injured (World Economic Forum, 2012). These factors are impacting not only the healthcare cost account concerning human resources, but also business actions and outcomes in general; therefore health should be considered a core business issue as it impacts core business outcomes (Lynch, 2002). In this regard, the perspective of occupational health is not sufficient, rather health should be pursued within a broader mindset associated with CSR (Montero, Araque, \& Rey, 2009). Along these veins this paper presents a grounded theory on how businesses can actively contribute to the advancement of health literacy as a part of their CSR to promote and sustain health at the workplace. The findings add to the evidence base on how health literacy strategies can potentially be shared and adapted to the broader business community in support of implementing the visions on healthy living as described in the various health related strategies of international organisations such as WHO, EU and the WEF 
(European Commission, 2007, 2010; World Economic Forum prepared in collaboration with Bain \& Company, 2013; World Health Organisation's European Office, 2012).

\section{Methods}

The study assumed a grounded theory approach based on the thematic analysis of the data obtained from the semi-structured in-depth, telephone interviews. According to Creswell, grounded theory is "a qualitative strategy of inquiry in which the researcher derives a general, abstract theory of process, action or interaction grounded in the views of participants in a study" (Cresswell, 2009). Thematic analysis is a conventional practice in qualitative research which involves searching through data to identify any recurrent patters (Ryan \& Bernard, 2003). A theme is a cluster of linked categories conveying similar meanings and usually emerges through the inductive analytic process which characterizes the qualitative paradigm. The process of data analysis includes three steps: 1) open coding: identifying and categorizing phenomena found in the text, 2) axial coding: fitting themes into a basic frame of generic relationships, and 3) selective coding: developing a single storyline ('grounded theory') (Strauss \& Corbin, 1990), The interviews were made with business members of CSR Europe, which is the leading European business network for corporate social responsibility (CSR Europe, n.d.-a). A web-based pre-study identified 34 suitable companies among the 75 business members, which actively positioned themselves to be engaged in health and wellbeing at work. Further details concerning the pre-study are described elsewhere by Sorensen \& Brand (Sorensen \& Brand, 2011a). Of the 34 companies contacted; fourteen confirmed their participation, while five rejected with the argument that they did not know enough about health literacy and rather wanted to learn from the outcomes of the study than taking part. Fifteen did not respond to the request in spite of receiving an additional invitation. The nonresponse was mainly assumed to be the same reason as the five companies which had rejected. Two trained interviewers; from Maastricht University and CSR Europe respectively (VS and CN), conducted the interviews in September-November 2011. They had different professional backgrounds; one in corporate social responsibility and the other in European public health. Taking into account that the differences could influence the way questions in the semistructured interviews were asked; ongoing dialogues and briefings took place after every interview to ensure a coherent approach in the data collection. The designated respondents from the fourteen participating multi-national companies worked in the area of human resource management and corporate social responsibility. The interview time varied between 10-60 minutes depending on the richness of information provided. The semi-structured interview guide (Table 9.1) included open-ended ques- 
tions to obtain information concerning specific issues such as descriptions of company related health literacy activities, the attributed financial and human resources, quality insurance; and transferability of the health activities as potential 'good practices' for other companies.

The interviews were recorded and transcribed verbatim before being analyzed with NVivo (Version 9), which is a code-based theory builder software package which includes the capacity to code, retrieve and assist in developing theoretical connections between coded concepts or themes (Berg \& Lune, 2011). The data regarding consumers and community engagement was omitted from the analysis since this study focused on work related initiatives for employees only. The three step iterative coding process was made by KS until theoretical saturation occurred, when no new information or themes were emerging from the data and when the grounded theory was thoroughly validated with the collected data (R. B. Johnson \& Christensen, 2012). Recognizing that the initial three step coding was performed by one investigator (KS) only, the three tiered theory was reviewed by the interviewers and key stakeholders from CSR Europe (the Joint Venture on Health Literacy) to ensure its rigor. Furthermore, to judge the standard of the qualitative data the trustworthiness criterion including: credibility, dependability, confirmability and transferability was applied (Miles \& Huberman, 1994), (Lincoln \& Guba, 1985). Ethical aspects were embraced by briefing respondents and asking for informed consent to use the data for research purpose. Interviewers were informed to respect confidentiality and acknowledge if respondents wished to stop the interview before completion. All respondents have been anonymised and for confidentiality reasons, all company related identity issues have been masked in citations. The principle of reciprocity was applied by informing the study participants about the results of the study (Ulin, Robinson, \& Tolley, 2004). 
Table 9.1 Interview guide: health literacy activities for employees as part of corporate social responsibility (CSR)

Guideline for interviews: Health literacy activities for employees as part of corporate social responsibility (CSR)

\section{Introduction}

Context A joint venture has been launched in October 2010 to facilitate the introduction of health literacy as an issue for corporate social responsibility. The Joint Venture is set up within the umbrella of CSR Europe and the initiative is called "Health Literacy: Improving health knowledge among our employees and communities". It is a two year project lead by a steering group consisting of representatives from MSD, Nestle, Microsoft, Edenred, Maastricht University and CSR Europe.

Aim The collaborative venture aims to explore how collaboration between companies and stakeholders can actively contribute to improving health literacy in Europe.

What is health literacy Health literacy entails people's capacities, skills, knowledge, motivation and confidence to access, understand, appraise and apply health information to form judgments and take decisions in everyday life in terms of healthcare, disease prevention and health promotion to improve quality of life during the life course.

Purpose of interview At the moment, the collaborative venture is developing a "Blueprint for Action in Health Literacy", based on good practices and case-studies. This management tool will help companies devise a framework for prevention, education on healthy choices and managing chronic diseases in the workplace. Your companies' possible program(s) on health literacy might constitute such good practice.

\begin{tabular}{|c|c|c|c|}
\hline & Key Topic & $\begin{array}{l}\text { Check whether the } \\
\text { following points are } \\
\text { mentioned }\end{array}$ & Questions \\
\hline 1 & $\begin{array}{l}\text { Health literacy } \\
\text { and/or health } \\
\text { pro- } \\
\text { jects/initiatives/ } \\
\text { programs in } \\
\text { company } \\
\text { This key topic is } \\
\text { to be kept short. } \\
\text { Sub questions } \\
\text { are only to be } \\
\text { asked in case the } \\
\text { information } \\
\text { provided by the } \\
\text { company is not } \\
\text { clear or does not } \\
\text { sound familiar }\end{array}$ & $\begin{array}{l}\text { Description } \\
\text { Title of pro- } \\
\text { ject/initiatives/progra } \\
\text { mmes } \\
\text { Description - content } \\
\text { Activities (relation to } \\
\text { health literacy?) } \\
\text { Target group: employ- } \\
\text { ees, community, ect. } \\
\text { Number of partici- } \\
\text { pants } \\
\text { Implementation: } \\
\text { continuous or cohorts. }\end{array}$ & $\begin{array}{l}\text { What kind of health programs do you offer your } \\
\text { employees referring to health literacy? If no pro- } \\
\text { grams offered on health literacy, what programs do } \\
\text { you offer concerning health? } \\
\text { What is the aim of the program? } \\
\text { What are the specific activities performed or ser- } \\
\text { vices provided? } \\
\text { Are there specific groups of employees you aim to } \\
\text { include in the program? } \\
\text { How many people do participate? } \\
\text { Who do participate: are they primarily men or } \\
\text { women, specific age? } \\
\text { Timeline: } \\
\text { When did the program start? How long is it in pro- } \\
\text { gress? } \\
\text { Does the program run continuously or in groups? }\end{array}$ \\
\hline 2 & Good Practice & Good practice & $\begin{array}{l}\text { Would you recommend any of the program(s) as an } \\
\text { example for good practice? } \\
\text { Why is it a good practice or not? Can you give rea- } \\
\text { sons/examples? } \\
\text { Are there any things you would like to change to } \\
\text { improve the intervention? What? Why? } \\
\text { Would you recommend running your program on a } \\
\text { larger scale or expanding it to other companies? } \\
\text { Which program or program elements would be } \\
\text { suitable for upscaling? } \\
\text { Why? Please give reasons. } \\
\text { Where would you see difficulties or barriers in } \\
\text { upscaling the program? Where is adaptation/change } \\
\text { needed? }\end{array}$ \\
\hline
\end{tabular}


Table 9.1 Interview guide: health literacy activities for employees as part of corporate social responsibility (CSR) (continued)

\begin{tabular}{|c|c|c|c|}
\hline \multicolumn{4}{|c|}{$\begin{array}{l}\text { PROGRAM DETAILS (TO BE INQUIRED WHEN COMPANIES' PROGRAM IS RECOMMENDED AS A GOOD } \\
\text { PRACTICE) }\end{array}$} \\
\hline 3 & $\begin{array}{l}\text { Continuation of } 1 \\
\text { above, detailed } \\
\text { description of } \\
\text { planning and } \\
\text { resources }\end{array}$ & $\begin{array}{l}\text { Description } \\
\text { Description - planning } \\
\text { \& resources }\end{array}$ & $\begin{array}{l}\text { Can you give an indication of the resources invest- } \\
\text { ed? } \\
\text { Money, man power, time, materials. } \\
\text { Can you describe the planning and implementation } \\
\text { process of the program? } \\
\text { Design? (costs, man power, time) } \\
\text { Implementation? (Costs, man power time, materials) } \\
\text { Where is the program implemented - throughout } \\
\text { the entire company or in certain specific depart- } \\
\text { ments? } \\
\text { Has the program been adapted to fit specific con- } \\
\text { texts? }\end{array}$ \\
\hline 4 & $\begin{array}{l}\text { Effective- } \\
\text { ness/Efficiency }\end{array}$ & $\begin{array}{l}\text { Effective- } \\
\text { ness/Efficiency } \\
\text { Definition of effective- } \\
\text { ness, efficiency, suc- } \\
\text { cess }\end{array}$ & $\begin{array}{l}\text { How do you determine the successfulness of the } \\
\text { program? Which criteria are used to judge the } \\
\text { effectiveness of the program? } \\
\text { Examples of criteria: } \\
\text { Number of participants } \\
\text { Less accidents } \\
\text { Less sick leave } \\
\text { Behaviour change } \\
\text { Etc. } \\
\text { How/when is the program evaluated? } \\
\text { Continously or at several pre-determined points in } \\
\text { time (monthly, yearly)? } \\
\text { Who is involved in the evaluation: program imple- } \\
\text { menters, individual participants, participant repre- } \\
\text { sentatives? } \\
\text { Method(s) of evaluation: discussion, questionnaires } \\
\text { (open or closed questions)? }\end{array}$ \\
\hline 5 & Conclusion & $\begin{array}{l}\text { Thank you } \\
\text { Sending of material } \\
\text { Interested: Webinar } \\
\text { November }\end{array}$ & $\begin{array}{l}\text { Thank you very much for your imput and contribu- } \\
\text { tion. } \\
\text { In case you are willing to share your program's } \\
\text { material with us, please email to the project coordi- } \\
\text { nator. } \\
\text { In case you are interested in the results of this } \\
\text { research and the progress of the Collaborative } \\
\text { Venture, more information will be provided during a } \\
\text { Webinar in November 2011, which you can sign up } \\
\text { for through CSR Europe. }\end{array}$ \\
\hline
\end{tabular}

\section{Results}

The analysis with NVivo resulted in 637 codes (nodes) forming three main categories such as 'strategic choice', 'health programmes' and 'sustainability', each with four to ten sub-categories, which in turn could be linked and associated with one core category labeled 'Development of health literate businesses'. The generated grounded theory 
concerning how health literate businesses can be developed within the realm of CSR is illustrated in Figure 9.1.

\section{Developing health literate businesses within the realm of corporate social responsibility}

Essentially, the study yielded a three-tiered grounded theory for developing health literate businesses within the realm of corporate social responsibility. To become a health literate business, the management must prioritize health and health literacy and form a strategic choice to integrate health as a corporate principle or value. Furthermore, the choice must be executed as build-in health programmes, rather than add-on health projects. Lastly, the build-in health-related business actions should be processed in a systematic and sustainable manner including focus on measurable indicators providing evidence on progress and efficiency as well as including an explicit focus on the advancement on health literacy as a component of health at work. Notably, the theory revealed a gap in health literacy efforts, hence there is a high potential for the advancement of health literacy to become part of health at work and strategic corporate actions. However, it requires a shift in the management mindset to integrate health as core business value in today's business world as a strategic, cost-efficient, transparent and measurable way to match the actual health and well-being needs in the workforce.

"What you need is a certain integrated approach that explains what is the business case for this kind of program, what is the benefit for the company, what is the benefit for the employees? Then you should start to develop a certain mid/long term program. A program that goes beyond a single event or a single campaign... This is much more than just a marketing campaign for health. It should be in the end part of the business".

The three-tiered grounded theory on developing health literate businesses in the realm of corporate social responsibility is described in detail in figure 9.1.

\section{Health literacy as a strategic choice}

The private sector needs to acknowledge as a prerequisite for the development of health literate businesses that investment in the health of employees is not only a "nice to have" attribute or philanthropic activity but it is a "need to have" investment; health is as important as other core investment in business facilities.

The generated theory demonstrates that the advantages of investing in health and health literacy are underestimated by businesses: there is a demand for a change of mind set toward health as a strategic core of the business. Only when companies realize that employees' health contributes to businesses' goals the business will be ready 
for change to commit to health and health literacy as a strategic choice in the realm of corporate social responsibility.

A systemic manner is required to integrate health and well-being to business structures and activities. The corporate backbone should include a strategy on health that enhances the well-being of employees and facilitates a health-oriented working environment, because ad-hoc events and information campaigns are not enough. Healthoriented environments can be facilitated by companies through the creation of internal structures, networks and platforms from which health programmes can be achieved. As a means of communication, information can be distributed through intranet and staff can volunteer or be appointed to execute the health programs, hence acting as health ambassadors within their company. Information must be easily accessible, and test can be implemented using self-tracking or self-monitoring methods. The health programmes can be outsourced or executed in partnership with external stakeholders such as cooperation with health clinics, either internally or externally, to perform regular check-ups on employees. However, the issue of privacy, which especially in Europe due to data protection, influence corporate involvement in health, remains a sensible issue; as there is a sensitive balance between how much employers should know about the health of their employees and how much a company should offer in terms of supporting health programs.

In addition, to strengthen coherence, it is essential to retain a guiding global corporate vision and mission and stimulate local adaptation with reference to local ethical, social, political and cultural values regarding health at work.

"With all these types of programs, the big challenge is the same. It often starts as a charity thing: Let's invest in it and hope that it may do some good. In the end these types of programs are only sustainable if you can show the real benefit of the program. The benefit to the company, the business case, includes less sickness and better motivated people".

\section{Health programmes}

There are various reasons to engage in health programmes at work. Some convey that the target include to foster employees' health and safety by providing a healthy and safe working environments. Others link it to charity, productivity, satisfaction and effectiveness. Hence, it may not only be to reduce absenteeism, but to enhance the health conditions of the workforce as well. A unique feature regards the implementation of a more holistic approach to health by considering physical, mental, social, emotional and spiritual health. While current health practices involve focus on safety, disease prevention and promotion of (mental) health and well-being along with caretaking, few projects target the issue of health literacy on its own. 


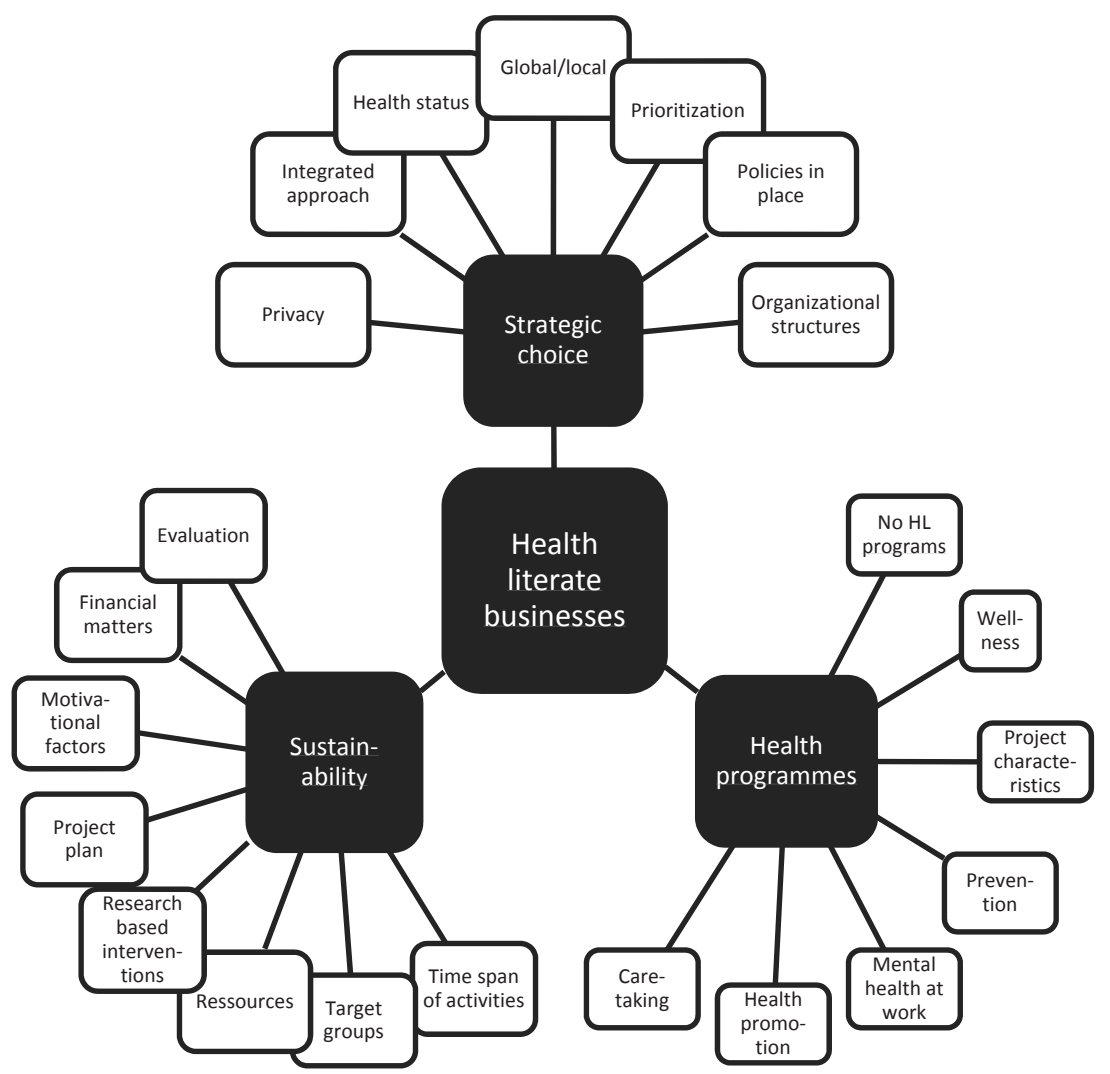

Figure 9.1 Grounded theory on how to develop health literate businesses in the realm of corporate social responsibility

Generally, health projects can be accomplished in a variety of ways. Some involve yearly activities, while others employ weekly or monthly themes as a component of an integrated systematic approach. Certain companies plan deliberately activities with milestones such as World Aids Day, the Week of Cancer and days related to special diseases as guidelines for their efforts. Other health events include marathons, football competitions, bicycling races, and mass vaccination days. Employees are often challenged to engage in an endeavor to improve their health: stop smoking, go on diet, lower cholesterol, do more exercise and were encouraged to make teams or compete with each other. The list of possibilities is endless; yet it is of importance that the activities undertaken are matching the needs of the people involved. Otherwise, there will be a mismatch between resources spend by the company and the outcome of the involvement of the employee. Several kind of incentives are often used to stimulate participation such as free fruit, free access to sport facilities or free smoking cessation courses. 
"Each employee is encouraged to create a team of other employees for whatever wellness challenge is at hand. Recently, we just did one that was a broad wellness challenge on becoming more active and then also eating healthier and also losing weight as that is a priority. It is more about healthy weight than it is about losing weight... This was a thee-month challenge that went on. Employees were encouraged to log all of their information and there was an interactive social platform where people could challenge each other to other wellness activities. At the end, if you completed everything you were incentivized with a gift-card for an online store"

\section{Sustainability}

The third tier refers to sustainability as an important factor for the development of health literate businesses. Hence, the investment in health literacy should involve systematic and sustainable considerations and choices concerning the target group and their needs, the motivational factors in play, the required priorities, the policies enacted to facilitate actions, the human and financial resources needed, the time span of activities, the organization and structures required and the evaluation and quality insurance means. However, on multiple occasions, it is not possible to judge the quality of many existing health programmes. Additionally, it is rare that the long lasting effect of the programs can be well explained. Thus, it is apparent from the generated theory that, although most companies execute health programmes, there is a lack of transparency in terms of the use of priorities and resources.

While, a majority of the health programs identified focus on food and nutrition, medical examinations and health check-ups as well as preventive measures such as smoking cessation and stress management, only few interviewees can rationalize the reasoning behind these priorities. Notably, the initiatives are often closely linked to the core business of the company, e.g. food industries significantly focus on nutrition. Nevertheless, motivational factors and incentives such as wellness bonuses, competitions and personal development opportunities are consistent phenomena, which are utilized to attract employees to engage in health programs and to increase awareness and involvement. Free entry and membership to fitness clubs and free fruit and water are also frequently used incentives. Most programs are not compulsory. Yet, the managers are implied to encourage and participate as role models in the anticipation of strengthening the participation among their employees.

Currently, the evidence and efficiency of the health programmes are rarely described. Only little information is provided concerning scientific evidence, methods or concepts. References to general knowledge about risk factors and the wide spread prevalence of non-communicable diseases are provided, however it is often perceived as a struggle to make the best match between actual needs and programmes to provide an optimal solution for the employees. 
While it is emphasized that policies need to be enacted to ensure health management in businesses, only few companies pursue thorough, formalized, integrated policies rather than outlines of health projects. The theory demonstrates that, in order to achieve improved health literacy outcomes at work, a systematic focus on the needs within the workforce to improve health-related knowledge, motivation and competences of the employees is required. In the view of creating sustainability assessment, monitoring and evaluation mechanisms are essential to follow the progress related to specific indicators related to health outcomes. It is imperative that initiatives are targeted to the specific needs of individuals and businesses should depart from the 'one size fits all' attitude when communicating to their employees about health.

"The ... health strategy will then have a vision, a mission and an implementation plan. Our vision and our mission entail to deliver health to all our employees and we have three areas. So it is obvious that the very first and important one is occupational health and safety, within the strategy. The second one would be health promotion. Including promoting health or creating awareness around health and doing tests all the way to understanding your treatment and all of that. The third one is that we have an epidemiology section... The plan to implement all these things will then have these overarching targets, one-year and five-year targets, and then we measure a certain set of parameters...across the world".

\section{Discussion}

As most people spend a considerable amount of time and energy at work, businesses can play an essential role in promoting and sustaining their employees' quality of life and healthy living. The study makes a unique contribution to the field of health at work as it seems to suggest that developing health literate businesses within the realm of CSR is a way to respond to the demands for smart growth as requested by the EU in Europe 2020 (European Commission, 2010) and health-oriented strategies such as Charter for Healthy Living (World Economic Forum prepared in collaboration with Bain \& Company, 2013), Health 2020 (World Health Organisation's European Office, 2012) and Together for Health (European Commission, 2007). The use of grounded theory and thematic analysis allows for a deeper understanding of the theory which emerged and its significance which entails the necessity to incorporate health literacy into health at work as a core priority and settled value within the business model; rather than as a component of add-on health projects. Furthermore, in accordance with the generated theory, the strategic focus on health literacy business actions should be two-sided including a dual responsibility which involves employees as individuals as 
well as the management teams to advance health literacy. In this regard the theory contributes by bringing in a pledge for a mindshift towards a stronger stratetic integration of health and well-being. As indicated by Montero et al. (Montero et al., 2009) the integrative mind shift has occurred in terms of safety which is highly regulated; however, improving health and well-being for employees have yet to be anchored into businesses' core policy, guidelines and actions in a sustainable manner. Although, the grounded theory on health literate businesses reveals that only few have pursued the integrated focus on health as a core business value so far, it is clear that some businesses are already executing this vision, hence with Gibson's words: the future is here, it is just unevenly distributed (Gibson, n.d.). To move forward the labor system can learn from the healthcare system about how to develop attributes to become a health literate organization (Brach et al., 2012).

The workplace constitutes a unique setting for empowerment and growth. It is a part of the daily life routine that provides opportunities for specific, targeted initiatives that match the needs of the individual employees. As in DNA, the strength is achieved in the string when the blocks are matched correctly. The process of systematic approach, measurement, comfortable fit and further evaluation is the key aspect of success for the integration of health literacy in strategic corporate efforts concerning healthy lives and health at work. As such, health literacy as an outcome of the corporate DNA can be an important building block to boost knowledge, motivation and competency of employees to assist them in making informed decisions in terms of health. It is also an essential building block toward creating a health literate working environment. The type and content of the programs should meet the needs, be evidence-based, of good quality and targeted to the people involved.

The CSR platform is convenient for discovering new frontiers, especially when the frontiers include aspects related to building the foundations of sustainable and efficient organizations (Scott, 2009); an aspect which has been supported by the theory generated in the current study. Preferably, the priority given to climate change and sustainability as part of the CSR agenda will, in the future, be shared with health. A paradigm shift will be reaching the tipping point when few become many to integrate health literacy as part of health at work efforts. Essentially, it is important to recognize that health literacy, health at work and healthy living form not only a segment of corporate social responsibility but also of corporate social opportunity in order to execute the necessary changes (Grayson, 2004). To increase the velocity of change the present study paves the way with concrete recommendations that include to:

- Integrate the advancement of health literacy as a strategic choice in the longterm core corporate management strategy concerning healthy living and health at work to ensure sustainable development and impact on health literacy and the health of the workforce. 
- Measure health and health literacy and prepare needs assessments to ensure a better fit in terms of programs and actual health needs within the workforce.

- Provide quality programs and activities that match the needs of the workforce and are adapted to the local conditions and settings to create long lasting effects.

- Provide ongoing evaluations of actions and expand the possibilities for further growth and empowerment when results are achieved to ensure continuous progress and motivation.

- Find a balance between individual choice and business interests in concordance with ethical and social values linked to the specific cultural and political settings in which the company is situated.

Certain limitations are worth noting for the current study; which were assessed by applying Lincoln and Guba's qualitative validation criteria (Lincoln \& Guba, 1985). The recruitment of key informants was a challenge. A reason for the $60 \%$ nonresponse was related to difficulties of reaching the appropriate people with the concrete knowledge about health programs within the companies. It may imply that certain aspects of health at work are not represented in the theory, however, since the profiles of the companies participating varied considerably and with a slight overweight of companies operating in the field of health and well-being; the non-response effect is assumed to be of minor effect. While the majority of interviews provided fruitful insights into current health activities, less transparency was pursued concerning financial and structural aspects of business actions on health. Therefore, these aspects should be further investigated in the future. While the findings of the study may not be empirically generalizable due to the specific context of the study design which, for example, implied recruitment of participants through CSR Europe, the evidence concerning health literacy as a strategic business action in the realm of corporate social responsibility is in general theoretically transferable. The credibility and dependability of the study have been strengthened by providing a visual model combined with 'thick' descriptions of the findings to enhance transparency and clarity concerning the generated theory. Finally, the confirmability of findings was assured through the development and adherence of a transparent work plan and through the engagement of staff from both CSR Europe and Maastricht University in the data collection and data analysis. 


\section{Conclusion}

The grounded theory concerning the development of health literate businesses in the realm of corporate social responsibility supports the call for strategic change emphasized recently by the WEF, the EU and WHO. Furthermore, the grounded theory can serve as basis for the development of a new action framework, which is the aim of the Blueprint of Business Actions on Health Literacy by CSR Europe. The findings clearly indicate that health-related decisions and actions are no longer related solely to the free fruit basket and fitness-room for employees as part of health projects; instead, the decisions in the boardroom are of even more importance to strengthen health at work as a core business value. Essentially, the crucial investment from management level in health literacy to support healthy living as part of the core corporate social responsibility can increase the well-being and health status for the individual and support corporate level outcomes for the benefit of the company as well as society as a whole.

\section{Acknowledgements}

The current study formed a part of the objectives of the Joint Venture on Health Literacy which was launched in October 2010 to explore how businesses can actively contribute to the improvement of health literacy in Europe and develop a Blueprint for Business Actions on Health Literacy. The steering group consisted of representatives from MSD, Nestlé, Microsoft, Edenred, Maastricht University and CSR Europe. The authors wish to thank Christine Neumann from CSR Europe and Vivian Stoffels from the department of International Health, Faculty of Health, Medicine and Life Sciences at Maastricht University for conducting the data collection. In addition the steering group of the Collaborative Venture on Health Literacy is thanked for fruitful feedback throughout the study process.

\section{Authors' contribution}

KS: Introduction, method, results, discussion and conclusion; KC: method, results, discussion and conclusion. HB: discussion. All authors have critically reviewed and accepted the manuscript. 


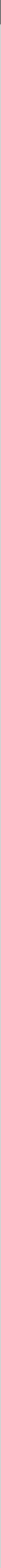


Life is a journey, not a destination.

Unknown author 


\section{CHAPTER 10}

\section{Blueprint on business actions on health literacy}

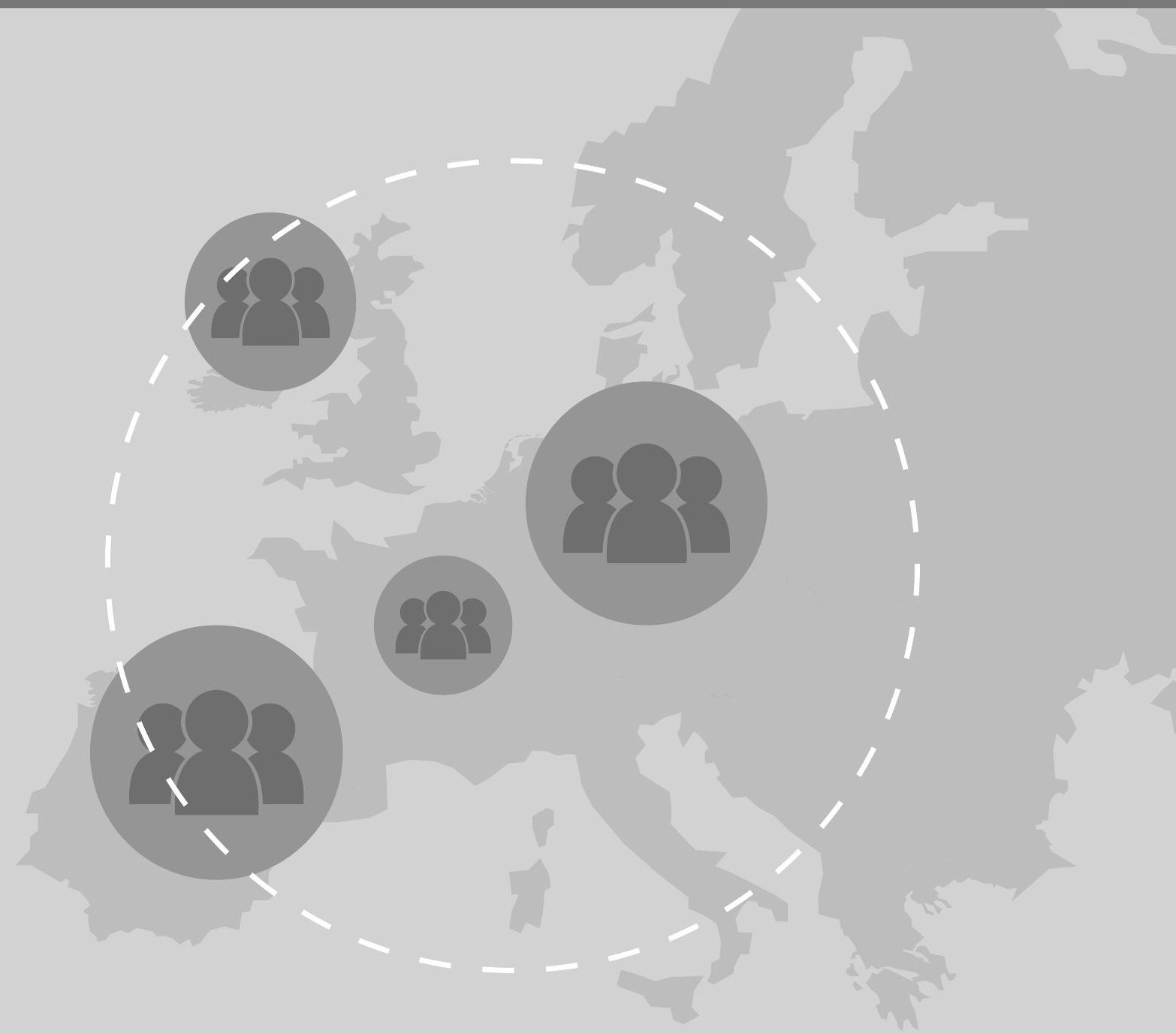

Kristine Sorensen in collaboration with Christine Neumann, Tanya Kennedy, Alexander Rödiger, Charlotte Malvy, Nolwenn Bertrand, Ray Pintus and Helmut Brand. Based partly on "Healthy Workforce, Healthy Society: Blueprint of Business Actions on Health Literacy". Launched 23 March 2013, European Parliament, Brussels 


\section{Introduction}

oday's working environment looks radically different from the one 20 years
ago. The times of stable hierarchies have gone. Today's workplace is in con-
stant change; mobility, flexibility and connection are the key requirements to
employees (Deloitte, 2009; Schriefer, 2005). To create successful companies
under these conditions Kolind and Bøtter advocate for a new type of business model
called the unbossed organisaiton. An unbossed organisation includes employees as
partners in the business development rather than merely as workers in a top-down
dominated structure. The process is grounded in organisations being unlimited in part-
nerships and approaches and acting with a clear ethical and social responsibility rather
than limited entities working in separate sectors for profit only (Kolind \& Bøtter, 2012).
Such development is positive as it provides a greater autonomy for the individual; yet
it is also a challenge since it requires greater self-responsibility from the employee and
appropriate knowledge and skills to manage work in complex and changing environ-
ments.

\section{How health literacy support a healthy workforce}

A pre-requisite for the success of companies is the availability of healthy employees (Lynch, 2002; Sorensen \& Brand, 2011a). As most people spend a considerable amount of their time and energy at work, businesses can play an essential role in promoting and sustaining employees' quality of life. The empowered employee is an asset for a successful and viable business; as the health literate employee is for a healthy work force. To protect, promote and maintain one's health requires health literacy; just as employees need knowledge and skills to perform their work to create a successful company. Health literacy can be defined as the capacity to make sound health decisions in the context of everyday life - at home, in the community, in the workplace, in the health-care system, in the market place and in the political arena (Kickbusch \& Maag, 2008). It is closely linked to literacy and entails the knowledge, motivation and competences to access, understand, appraise and apply information to make decisions in terms of healthcare, disease prevention, and health promotion to promote and maintain quality of life during the life course (Sorensen, Van den Broucke, et al., 2012). Health literacy is an outcome of formal and informal health education (Nutbeam, 2000 b) and it is closely associated with empowerment (Kickbusch \& Maag, 2008). Research has indicated that the benefits of health literacy improvement include improved communication, greater adherence to treatment, greater ability to engage in self-care, improved health status and greater efficiency and cost savings to the work- 
place and health system as a whole (DeWalt, Berkman, Sheridan, Lohr, \& Pignone, 2004; Eichler, Wieser, \& Brügger, 2009; Friedland \& O’Neill, 1998; Spycher, 2006).

Interestingly, the idea of employees becoming self-managers and co-managers of the business development in 'un-bossed' organisations mirrors the trends in the health sector where people and patients are increasingly engaged in self-management and co-management of their own health (Adams, 2010; Roman \& Harris, 1997). The synergies can be unfold by focusing on how companies can become active actors in creating a healthy work force and investing in health literacy and hence contribute to a healthy society within the realm of corporate social responsibility. Corporate social responsibility can be defined as "the responsibility of enterprises for their impacts on society... to fully meet their corporate social responsibility, enterprises should have in place a process to integrate social, environmental, ethical, human rights and consumer concerns into their business operations and core strategy in close collaboration with their stakeholders p. 6" (European Commission, 2011).

\section{Exploring how to develop health literate businesses}

Since 2010 a Joint Venture on Health Literacy as Business Action has been active in the realm of CSR Europe with the aims to turn the concept of health literacy into practical action; to provide companies with innovative tools to increase health literacy through integrated health and well-being programmes with their employees; and to improve the health and well-being of employees and their communities, leading to greater productivity and society health (CSR Europe, n.d.-b). The work undertaken by the partners included a scope study (Sorensen \& Brand, 2011a); an in-depth study to develop a grounded theory on how to develop health literate businesses (Sorensen, 2011) and the development of a Blueprint (Joint Venture of Business Action on Health Literacy \& CSR Europe, 2013). The scope study revealed that

- though health programmes are provided by many companies, they are often not part of a broader strategy of developing the potential of the employees to flourish;

- though common health activities concern safety, prevention or health promotion, focusing mainly on physical activity, diet, smoking cessation, health checkups and stress management; the implementation patterns are diffuse rather than based on evidence.

- most companies used project-based solutions, rather than applying a centralised strategic approach to health investment in employees; 
- few companies had well developed monitoring and indicator systems to provide baseline and follow-up data on health and well-being;

- approaches and methodologies differed depending on size, business culture, work sites, needs and interests; but were often not evidence based and rationales could not be explained;

- the willingness to engage in health related activities revealed a strong potential to develop health literacy in a more coherent and strategic way.

The in-depth qualitative study on how to develop health literate businesses in the realm of corporate social responsibility generated a three-tiered grounded theory (Sorensen, 2011). The theory indicated that health literate businesses need to make health at work and the investment in health literacy a strategic choice, which means to integrate health as a core business value. Secondly, the companies should integrate health as part of policies and build-in programmes, rather than add-on health projects. Lastly, businesses should pursue a sustainable approach including measurement and evaluation of health and well-being to ensure the optimal fit between use of business resources and efforts of employees. Businesses should set up supporting structures that can implement corporate health strategies adapted to local conditions and settings ensuring respect for e.g. privacy and culture.

To bridge the concerns identified in the scope study and build on the recommendation from the grounded theory generated in the in-depth study; a Blueprint was developed which combined public health recommendations on health literacy and health at work with business principles including a sustainable approach to meet the demands of the current health challenges and proactively influence the changing work context (Joint Venture of Business Action on Health Literacy \& CSR Europe, 2013) as outlined in Figure 10.1. The rationale aimed at ensuring health and well-being of employees to become a core business priority and constant value within the business model and not only perceived as add-on projects for consumers, employees and other stakeholders.

Hence, the Blueprint was primarily developed by the steering group of the Joint Venture associated to CSR Europe. The steering group consisted of a cross-disciplinary, multicultural and European based group of professionals representing academia on health literacy (Maastricht University); corporate social responsibility (CSR Europe), health at work (BITC - Business in the Community) and business stakeholders from a variety of areas (MSD, Nestlé, Edenred, Microsoft) in the period from winter 2011 to summer 2012. For validation purpose the Blueprint was presented three times to a broader audience during the development process; twice in webinars with business members of CSR Europe and once in a stakeholder seminar with representatives from 
the European Commission, academia, non-governmental organisations and business members of CSR Europe. The feedback from all audiences was used to improve the framework in its design and content.

\section{The "Blueprint of Business Action on Health Literacy"}

The main purpose for developing the Blueprint was to provide a strategic framework for health literacy to become an integral part of business actions and corporate social responsibility. Hence the Blueprint of Business action on Health Literacy addresses six action areas: 1 ) to establish the business case on health literacy; 2 ) to ensure management buy-in; 3) to make a need assessment; 4) to match needs with existing initiatives in the company and prioritize; 5) to stop, start and continue initiatives that will advance health literacy and 6) to evaluate and monitor the developments and outcomes.

\section{STEP 1: Establish a business case}

The business case must demonstrate to management that health literacy represents added value for the company. Without such evidence, it is unlikely that the resources, or support, will be made available. Generally, the business case should answer the following basic questions: what is the problem? What should be done about it? Why should something be done? What are the risks, benefits, and costs? Who are the stakeholders? How will success be measured? The importance of establishing the business case for each company highlights the idea that no size fits all; the content of the argumentation will vary from company to company depending on e.g. type, location, purpose, employee profile, etc.

\section{STEP 2: Management buy-in}

Without management buy-in cultural inertia will fight against any proposed change, regardless of how important or necessary it is to future success. Lack of management buy-in can come from two places, top down, or bottom-up. A health and well-being programme will only be effective if it is supported at the highest level of management and filtered down throughout the organisation. Whilst both senior and operational management buy-in are essential, senior management buy-in can be cascaded down to operational staff quite effectively. Conversely, it is harder for buy-in from operational staff to be pushed up to senior managers. However, if buy -in is not achieved at all levels, any change is likely to fail.

\section{STEP 3: Needs assessment and analysis}

If the health needs and interests of the workforce are not understood, it is not known whether they are addressed, or a programme is delivered that is achieving return on 
investment (ROI). The needs analysis should provide a 'snapshot' of the current health and health literacy profile of the organisation in measurable key performance indicators (KPIs) so that it is possible to assess the success of health programmes. Initial baseline assessment is critical to a detailed analysis that will support programme development and monitoring. The time spent at the outset gathering the relevant information will have a significant impact upon the success of the programme. Hence companies should assess their existing strategic policy frameworks for improving health at work, their existing health programmes and measure health literacy as well as assess the health and well-being profile of employees in general.

\section{STEP 4: Match and prioritise}

The outcome of the needs assessment combined with a review of existing programmes provide the evidence base for a clear prioritization in terms of what the needs are to improve health literacy and well-being; what programmes are already undertaken that can serve the purpose, what should be developed or outsourced to move on and what should be stopped because the effect is lacking. The matching step is essential to ensure a better fit between the needs in the company and the resources available and will support the cost-benefit of the programmes short term and long term. It turns the focus on the initiatives that are appropriate within a certain company to match the specific needs specifically for these employees, rather than highlighting a general approach of 'one size fits all' or 'nice to have' instead of 'need to have'.

\section{STEP 5: Stop, start, continue}

Depending on the assessment outcome, companies may continue existing activities, modify some of them or develop new programs. These decisions should be based upon the key areas of potential risk for employees in terms of their health and for the business.

\section{STEP 6: Evaluate}

To develop health literacy in the workplace is a continuous process. Therefore, actions in the area of health at work require regular monitoring in order to assess whether the programs are effective and value for money. The Blueprint as strategic framework includes focus on evaluations and provides tools to monitor activities so that areas of improvement can be discovered and appropriate actions developed. Essentially, the six action steps are repeated to continuously ensure the best match between the needs of the employees and the programmes offered to advance health literacy and well-being at work.

It should, however, be noted that the design process of the Blueprint has limitations. The framework is the result of collective research and reflections of the crossdisciplinary, multinational and business-dominated group. Although it has been reviewed by stakeholders from the business community and the European Commission, 
the framework has not yet been validated in practice as a whole. For this purpose pilot projects organised by CSR Europe are planned to take place in selected companies in 2013/14. The group developing the Blueprint was primarily rooted in European academia and business settings; yet, as the business stakeholders primarily represented multinational companies, there are reasons to expect that the transferability of the framework could include companies in other regions at global level. Nevertheless, the result of the design process for a strategic framework such as the Blueprint on Business Actions on Health Literacy suggests that businesses may embrace the idea of a systematic, strategic and cost-effective approach to advance their role as advocates for health at work.

\section{Health literacy as part of corporate DNA}

The importance of business actions for a healthy work place and a healthy society is widely recognized (World Economic Forum prepared in collaboration with Bain \& Company, 2013; World Health Organisation, 2008) and the inclusion of health as part of corporate social responsibility is highlighted (European Commission, 2011). The call for developing health literate healthcare organisations (Brach et al., 2012) can be mirrored to a call for health literate businesses to benefit from the workplace changes and meet the demands of the future. Although many businesses currently engage in health at work (Lynch, 2002); coherent, cost-efficient and evidence-based health and wellbeing strategies at corporate level are missing (Montero et al., 2009). As Kolind and Bøtter (Kolind \& Bøtter, 2012) call for a shift in mind set in business settings towards higher emphasis on shared responsibility; Kickbusch similarly calls for a new mind set in health, which focuses on advancing health literacy and learning for well-being (Kickbusch, 2007, 2012). In this study a new Blueprint that can accommodate health literacy recommendations and business principles is proposed to advance communication and integration of health literacy as part of business actions and corporate social responsibility. The Blueprint on Business Action on Health Literacy entailed six action areas: the establishment of the business case on health literacy; the management buyin; the need assessment; the match and prioritization phase; the stop, start, and continue phase and finally, the evaluation phase. Whilst safety and training are areas which are regulated, monitored and incorporated at a strategic level, well-being and health literacy have yet to be better anchored in the core policy and business guidelines and actions. 


\section{Blueprint for Business Action on Health Literacy}

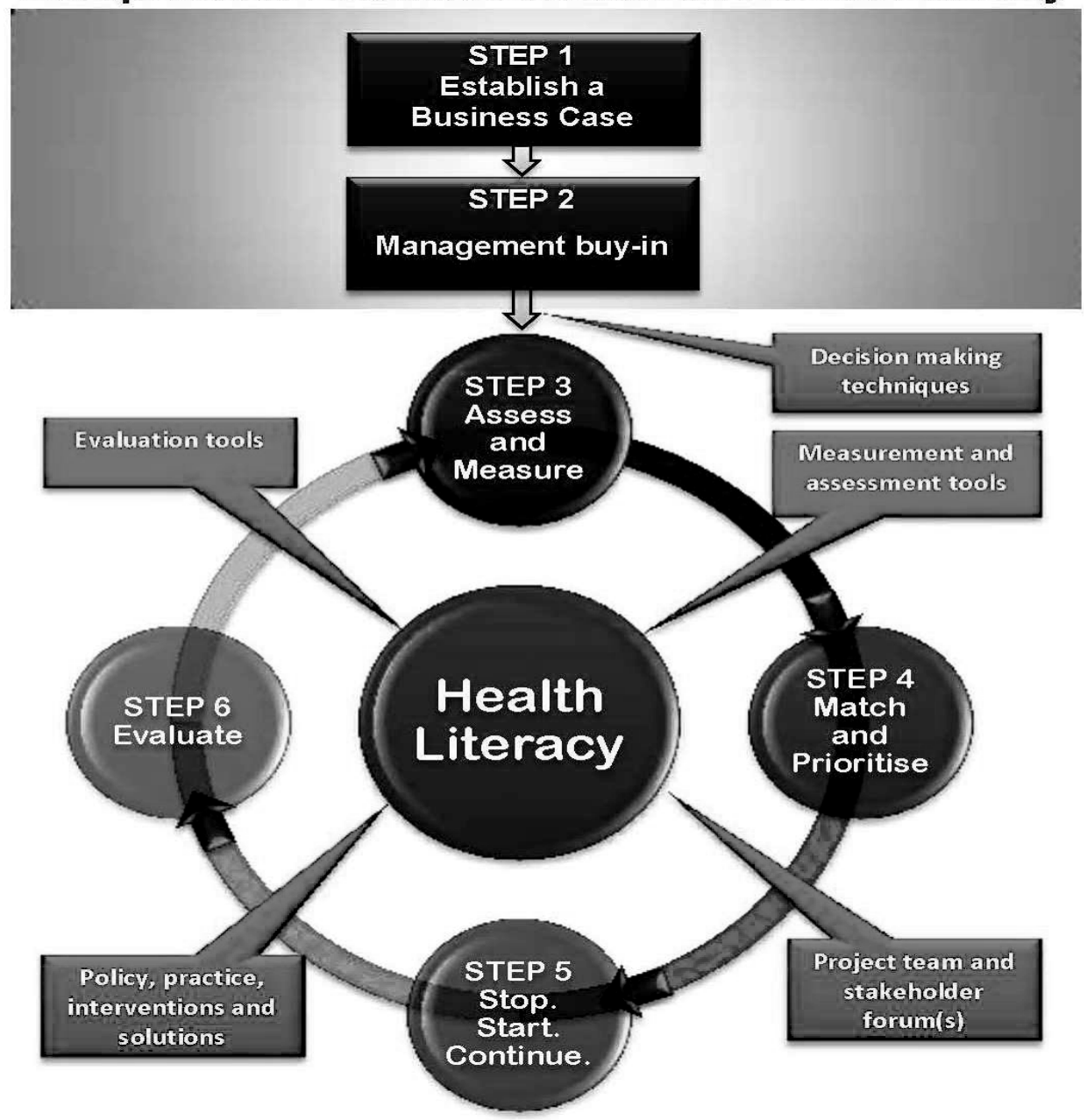

Figure 10.1 Blueprint of Business Action on Health Literacy

The Blueprint makes health literacy operational at a company level. The execution of the action areas results in a stepwise creation of a tailor-made corporate strategy to strengthen health communication and integration of health literacy as an asset and corporate value offering a meaningful corporate platform for a better understanding of the relationship between the individual, the workplace, health and quality of life. Additionally, in following the blueprint, companies must understand that 'one size does not fit all', and that any approach to achieving an increased level of health literacy must address the specific needs of each organisation and adjust actions to setting, culture, demographics, ethics, etc. The well-being and health literacy of employees 
should become a sustainable core priority and constant value within the business model and is not to be perceived as an add-on project for consumers, employees and stakeholders. Monitoring must be established at the outset of the programme to evaluate the health literacy among the workforce for continuous improvement and empowerment. Notably, no two programmes resulting from this approach will look the same; however, the steps to achieving and maintaining such a programme are similar. As a point of reference a toolkit is accompanying the Blueprint. The tools accomplish the different action areas in the Blueprint and cover management decision aids, assessment tools, and interventions to advance health literacy, prevention, and managing chronic diseases at the workplace, healthy lifestyle in the fields of nutrition, physical activity and psychological well-being. The toolkit is not exhaustive and should be seen merely as an inspirational snapshot illustrating possible ways to execute action areas outlined in the Blueprint.

Health literacy as part of the corporate DNA can be seen as an important building block to boost the knowledge, motivation and competence of employees to make qualified, suitable and realistic decisions in terms of their own health. It is also an essential building block towards designing a 'health literate' working environment, where it is easy to manage one's own and others health and well-being. As in DNA strength is achieved in the structure, when genes are matched correctly. Likewise the strategic framework represents a systematic approach of measurement; right fit and further evaluation, as key determinants of success. Most notably, the result of the study indicates a solution to create coherent, cost-efficient and evidence-based corporate based strategic initiatives to be embedded in e.g. a company's corporate social responsibility. By making the business case for health literacy the company engage in the empowerment of employees by moving from 'well-being at work' to 'learning for well-being for life' giving individuals the knowledge and capability to take control of their personal health and quality of life.

\section{Authors' contribution}

The writing of the Blueprint of Business Actions on Health Literacy has been shared between all stakeholders in the Joint Venture on Health Literacy of CSR Europe at different stages in the development process. The chapter is partly based on the Blueprint text and elaborated for the purpose of the thesis by KS. 


\section{Acknowledgements}

The authors wish to thank all members of the steering group of the Joint Venture on Health Literacy as Business Action, in particular Stéphane Cosandey and Cécile DuprezNaudy from Nestlé. Furthermore, thanks are given to staff at CSR Europe, in particular Jan Noterdaeme and Stefan Crets for making the Blueprint of Business Action on Health Literacy a flagship of Enterprise 2020. All participants in webinar and seminars organised by CSR Europe are acknowledged for their contribution to the refinement of the Blueprint. In addition members of the European Parliament, in particular Karin Kadenbach is thanked for her on-going support to the advancement of health literacy in Europe and for hosting the launch event of the Blueprint at the European Parliament. 
I hope you will judge yourselves not on your professional accomplishments alone, but also how well you have addressed the world's deepest inequities.

Bill Gates 


\section{CHAPTER 11}

\section{Health literacy, social justice and ethics}

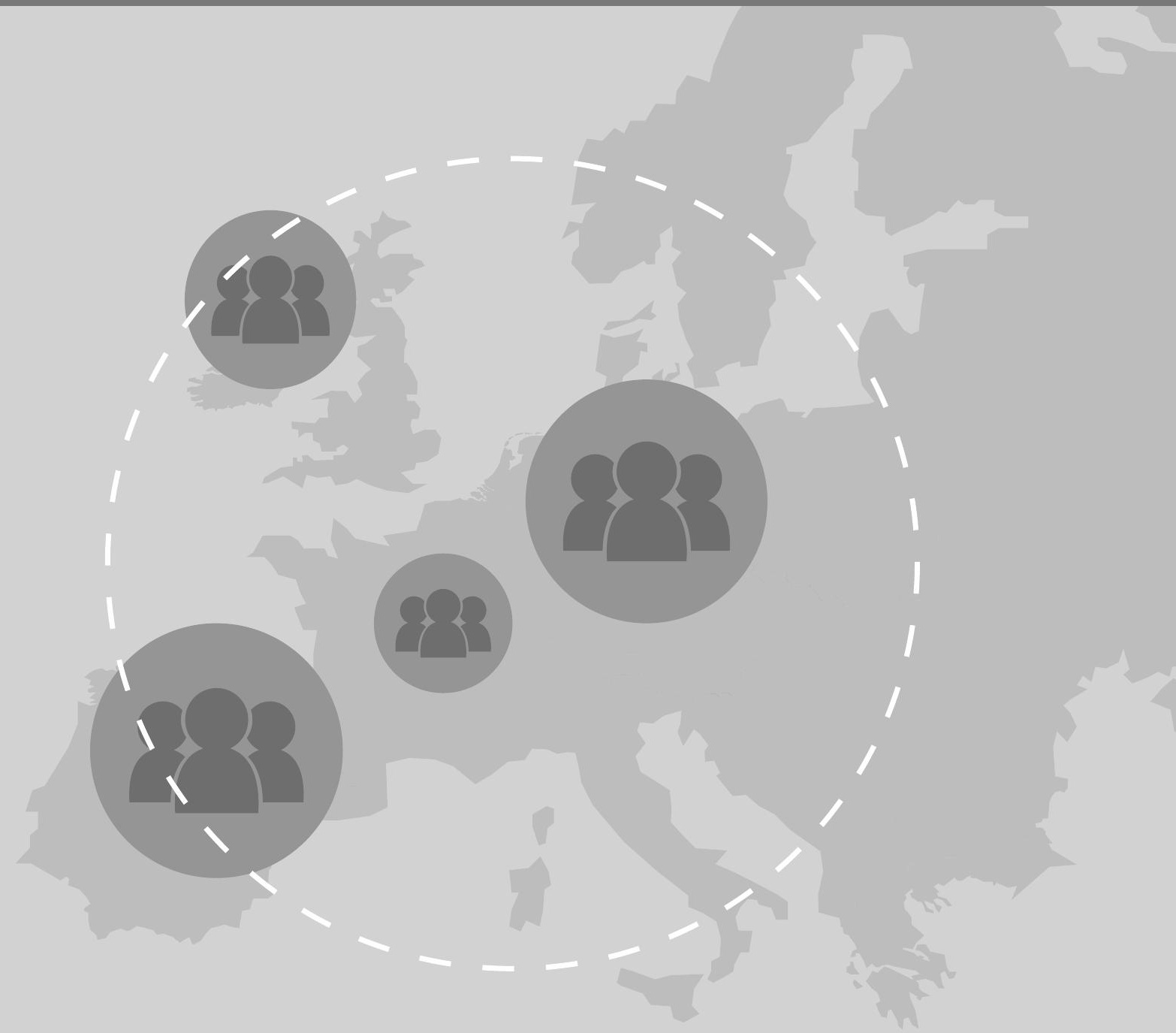




\begin{abstract}
Recent research has shown limited health literacy to be an underestimated phenomenon in Europe raising ethical concerns in terms of equity and social justice. The aim of the study is to explore the ethical scope of health literacy to strengthen the vision on what societies and people ought to do to address health literacy disparities. This paper elaborates health literacy from an ethical point of view in the scope of inequalities, quality of life, social justice and human rights complemented with the capabilities approach by Nussbaum to support a new ethical perspective on health literacy and social justice, which includes the view of health literacy as a dual responsibility of citizens and societies and integrates the capabilities approach to strengthen health literacy as normative social practice to enhance health, quality of life and human development allowing for freedom of choice and an acceptance for diverse outcomes.
\end{abstract}




\section{Introduction}

$\mathrm{H}$ ealth literacy is associated with social determinants of health (Pleasant, 2011) and the advancement of health literacy is a global health challenge that can be linked to human development and quality of life (Nutbeam, 2000b). The notion of health literacy is defined as the knowledge, motivation and competence to access, understand, appraise and apply information to make judgments and take decisions in terms of healthcare, disease prevention and health promotion in order to promote and improve quality of life during the course of life (Sorensen, Van den Broucke, et al., 2012). Notably, promoting health literacy is a critical empowerment strategy to increase people's control over their health, their ability to seek out information and their ability to take responsibility (Kickbusch \& Maag, 2008); and also the advancement of health literacy is recognized as an ethical imperative (Gazmararian, Curran, Parker, Bernhardt, \& DeBuono, 2005b; Volandes \& Paasche-Orlow, 2007).

However, limited health literacy is a phenomenon that is underestimated in research, policy and practice in Europe. The European Health Literacy Survey (HLS-EU survey) revealed that almost one in two has problematic or inadequate health literacy; there is a remarkable social gradient for health literacy in various countries in Europe (HLS-EU Consortium, 2012a). The survey demonstrated that health literacy is associated with age, employment status, social status, financial deprivation and education; some sub-populations were more exposed for limited health literacy than others. These include people with a low self-perceived social status, bad self-assessed health status, low education, suffering from financial deprivation, having severe health related limitations of daily life, age of 76 years or older, or with low self-assessed social status (HLS-EU Consortium, 2012a). In addition, the adverse effects of limited health literacy is associated with increased morbidity and mortality; difficulties in terms of health service provision; fewer opportunities for active participation and selfmanagement; as well as the jeopardizing of basic rights to health protection (Saha, 2006; Sentell \& Halpin, 2006; Volandes \& Paasche-Orlow, 2007). The social gradient and the inequality, in terms of opportunities exposed with limited health literacy, align with a general statement of the Commission for Social Determinants of Health, namely, that poor health is not only confined to those worse off. Countries with all levels of income, health and illness follow a social gradient: the lower the socioeconomic position, the worse the health (Commission on Social Determinants of Health, 2008). However, the Commission on Social Determinants also argues that reducing social inequalities in health, and thus meeting human needs, is an issue of social justice since the differences in health that are closely linked with degrees of social disadvantage should not exist (Commission on Social Determinants of Health, 2008). Notably, inequalities in health between and within countries are avoidable (Whitehead, 1991) and the gradi- 
ent in ill health can be considered a waste of human capital (Marmot, 2004). Although the promotion of health literacy is included in the European Commission's Health Strategy Together for Health (European Commission, 2007), the European Commission has limited competence in this arena and is governed mainly under Member State regulation. The European Union is therefore limited in its ability to provide an encompassing, preventive and promoting public health approach that includes a focus on health literacy (Schröder-Bäck et al., 2012).

Exploring the ethical scope of health literacy is crucial for a stronger vision on what societies, for instance the EU Member States, and people ought to do in terms of facing limited health literacy as a public health concern. As ethics in relation to health literacy has only been marginally researched (Schuh, 2011); this paper aims to argue the ethical case of health literacy by elaborating the following four theses.

- From an ethical perspective health literacy provides a crucial cornerstone to the achievement of quality of life as outlined by Aristotle by enhancing the critical reflectivity of citizens to engage actively in decisions concerning their own health and well-being as a means towards a higher standard of living.

- Health literacy is tightly linked to ambitions for entitlements, duties and freedom related to the advancement of sustainability and human development as reflected in the Declaration of Human Rights and the capabilities approach by Nussbaum.

- Health literacy attributes health and well-being as a means to quality of life by stimulating self-definition, active realization and value-driven decision-making based on a dual responsibility of the individual and society which, in turn, requires freedom of choice and an acceptance for diverse outcomes.

- The burden of limited health literacy and other cumulated health-related disadvantages are not acceptable from an ethical point of view and call for action.

\section{Health literacy to maintain and promote quality of life}

Health literacy is closely linked to the notion of quality of life according to the definition of Sørensen et al. (Sorensen, Van den Broucke, et al., 2012), and quality of life is, in turn, related to equity and social justice as these normative concepts aim at equal opportunities in achieving quality of life (Nussbaum \& Sen, 1993; Powers \& Faden, 2006). In recent times, the World Health Organization defines quality of life as "individuals' perception of their position in life in the context of the culture and value systems in which they live and in relation to their goals, expectations, standards and con- 
cerns" (World Health Organisation. Division of mental health and prevention of substance abuse., 1997). However, there is a variety of alternatives since it is clear that quality of life is defined differently by different people (Fayers \& Machin, 2000). These differences may be correlated with various political views, with attachments to different religions or to none and with what individuals enjoy and admire (Mackie, 1990).

In the Nichomachean Ethics, Aristotle (384-322BC) provides an account of 'What is a good life?' and how society can be organized to make such a life possible (Bartlett \& Collins, 2011)). According to Buchanan (Buchanan, 2000), Aristotle made a consistent distinction between 'health' and 'well-being'. Health (holos) referred to biological functioning, but 'well-being' was denoted by the Greek term, eudemonia, which may also be translated as 'flourishing', 'happiness', 'blessedness', or 'prosperity'. In Aristotle's writings, flourishing and happiness is the ultimate good, the telos (end, goal) of all human activity guided by reason. Health and wealth were mere instrumental goods, hence, they are sought not for their own sake but because they provide a means to bring about some other desired state. Aristotle regarded eudemonia as the highest goal of human activity (Buchanan, 2000). By definition, eudemonia is complete in itself and therefore not wished for in order to attain some other end (Bartlett \& Collins, 2011).

When applying the prism of Aristotle, the concept of health literacy becomes more transparent. The reason why one should be able to access, understand, appraise and apply health information is not only to excel in the domains of healthcare, disease prevention and health promotion when one is ill, at risk or trying to stay healthy. It has a superior purpose which is to promote and sustain quality of life and to be able to live a life with integrity for the sake of the ultimate good; eudemonia. As such, health literacy relies on the individual's knowledge, critical consciousness, contemplation and human development in terms of making qualified decisions as well as on societies where personal participation and choice in health matters are enhanced.

\section{Health literacy, social justice and human development}

Inspired by Aristotle, Nussbaum has extensively compared and evaluated countries in terms of decency and justice by focusing on health and 'What is each person able to do and to be?' (Nussbaum \& Sen, 1993). Nussbaum (Nussbaum, 2011) argues that health is one of several capabilities that people need to achieve in terms of developing a good life and claims that those capabilities are closely linked to human rights and societal responsibility as they lay the foundation for understanding what people morally owe each other. In other words, by the virtue of human beings having human dignity, they have positive rights to be able to live good lives, which is consistent with the political 
understanding of human rights, for instance, in the Declaration of Human Rights Article 25 on the right to a standard of living adequate for the health and well-being of a person and his/her family (United Nations Department of Public Information., n.d.). Thus, according to Nussbaum (Nussbaum, 2011), the capabilities approach entails that societies have the obligation to promote a set of real opportunities or substantial freedoms for their people which people then may or may not exercise in action: the choice is theirs. She proposes ten capabilities: 1) life; 2) bodily health; 3) bodily integrity; 4) senses, imagination, and thought; 5) emotions; 6) practical reason; 7) affiliation; 8) other species; 9) play; and 10) control over one's environment (political and material).

The capabilities approach commits itself to respect for people's powers of selfdefinition. Thus, these are not just abilities held by a person but also the freedoms or opportunities created by a combination of personal abilities and the political, social, and economic environment - the substantial freedoms as combined capabilities in the optic of Nussbaum. The notion of freedom to choose is thus built into the notion of capability and it follows that a decent political order must secure for all citizens at least a threshold level of the ten central capabilities. In this regard, health literacy is essential because it is capturing exactly the positive freedom that is - among other things needed for achieving good health (as requested by Nussbaum's capabilities) in combination with the freedom of making choice. Thus, to have health literacy could be conceptualized as a necessary transcendal good within Nussbaum's approach: one has to know potential consequences of ones action for health to make good and right choices, even if persons ultimately would posteriorise health trading it for another good. Along this vein Rubinelli, Schultz and Nakamoto argue that to be health literate includes the ability to exercise self-reflection, hence to connect health information external to the individual with her own worlds of knowledge, beliefs and values and prompts recognition of potential failures that might obstruct the achievement of developing a good life. However, they emphasize that health literacy does not favour 'subjectivism' in the form of falsification or freedom of re-interpretation of the facts. In turn, if health literacy is to lead to improved health outcomes and well-being, the health literate person cannot distort or ignore relevant facts; it requires acceptance of the truth and the eventual correction of erroneous or inconsistent beliefs (Rubinelli, Schulz, \& Nakamoto, 2009).

\section{Advancing health literacy through dual responsibility of the individual and the society}

The question of dignity and health literacy is reflected by Parker and Ratzan who claim health literacy to be truly aligned when the competences of individuals fit the de- 
mands of the health contexts and systems (Parker \& Ratzan, 2010). This point reflects the capabilities approach which also insists that all entitlements involve an affirmative task for governments to actively support people's capabilities, not just fail to set up obstacles (Nussbaum, 2011). In line with Nussbaum, Buchanan proposes that focus should be shifted from behaviour modification to a principal priority of supporting people to improve their own capacity for practical autonomy and demand a new ethic based on the philosophy of education and become more conscious of collective responsibilities to create a just society (Buchanan, 2006). In addition, the view of dual responsibility reiterates the idea of co-production of health, which goes "beyond the idea of 'citizen engagement' or 'service user involvement' to foster the principle of equal partnership. It offers to transform the dynamic between the public and the public service workers, putting an end to 'them'and 'us'. Instead, people pool different types of knowledge and skills, based on lived experience and professional learning" (Boyle \& Harris, 2009). The inclusion of 'people-centered health' as a value in the Health 2020 strategy of the World Health Organisation's European Office (World Health Organisation's European Office, 2012) reflects such a change of view from regarding people as passive recipients of health services to active partners and comanagers of their own health.

\section{Concluding remarks}

The ethical scope of health literacy presented in this paper follows previous discussions by Rubinelle, Schultz and Nakamoto on health literacy as a 'phronesis', a 'practical wisdom' with respect to the account of Nicomachean Ethics (Rubinelli et al., 2009). Likewise has Ratzan presented the thinking of Aristotle in his article concerning health literacy as communication for the public good (Ratzan, 2001). Already a decade ago Kickbusch referred to the views of Sen and Nussbaum regarding the importance of the capabilities approach in terms of economics, health and sustainability with reference to the then emerging area of health literacy (Kickbusch, 2002); however, so far the application has gained little attention in academic literature. Nevertheless, the capabilities approach itself is widely applied in the field of health for instance in association to public health (Saith, 2011), mental health (Hopper, 2007; Lewis, 2012); health justice (Fins, 2012). Ruger supplements the discussion by defining health capabilities in their own rights (Ruger, 2010). Yet, the capabilities approach has also limitations which for instance include the challenge of operationalization (Robeyns, 2006); and in terms of health economics, whether the aim is a 'decent minumum' of capability or presuming that the goal must be the maximization of capability (Coast, Smith, \& Lorgelly, 2008). 
Furthermore, the trend of self-management and individualization poses the risk that collective and societal responsibility is delegated to individuals (Kickbusch, 2002).

Stipulating that the advancement of health literacy encounters barriers in terms of inequalities through a strong social gradient and believing that the uneven distribution of health and health literacy can be considered unnecessary and avoidable and, definitely, unfair from a social justice and human rights point of view, the ethical vision on what societies and people ought to do in terms of health literacy needs to be strengthened. It is important to strive for more social justice and promote a new ethical understanding of the role of citizens and societies in the co-promotion of health. In this respect, the integration of the value and rights perspective entailed in Nussbaum's capabilities approach maybe a game changer when addressing the ethical concerns related to health literacy disparities in order to improve quality of life. Based on this philosophy health literacy attributes health and well-being as a means to quality of life by stimulating self-definition, active realization and value-driven decision-making based on a dual responsibility of the individual and society which, in turn, requires freedom of choice and an acceptance for diverse outcomes.

\section{Authors' contribution}

$\mathrm{KS}, \mathrm{PSB}$ and $\mathrm{HB}$ have in collaboration developed the ethical case on health literacy presented in this paper. 


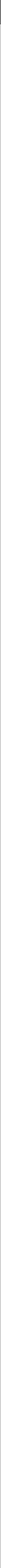


Never doubt that a small group of thoughtful committed citizens can change the world; indeed, it is the only thing that ever has.

Margareth Mead 


\section{CHAPTER 12}

Health literacy and citizen consultations:

shaping health literate societies

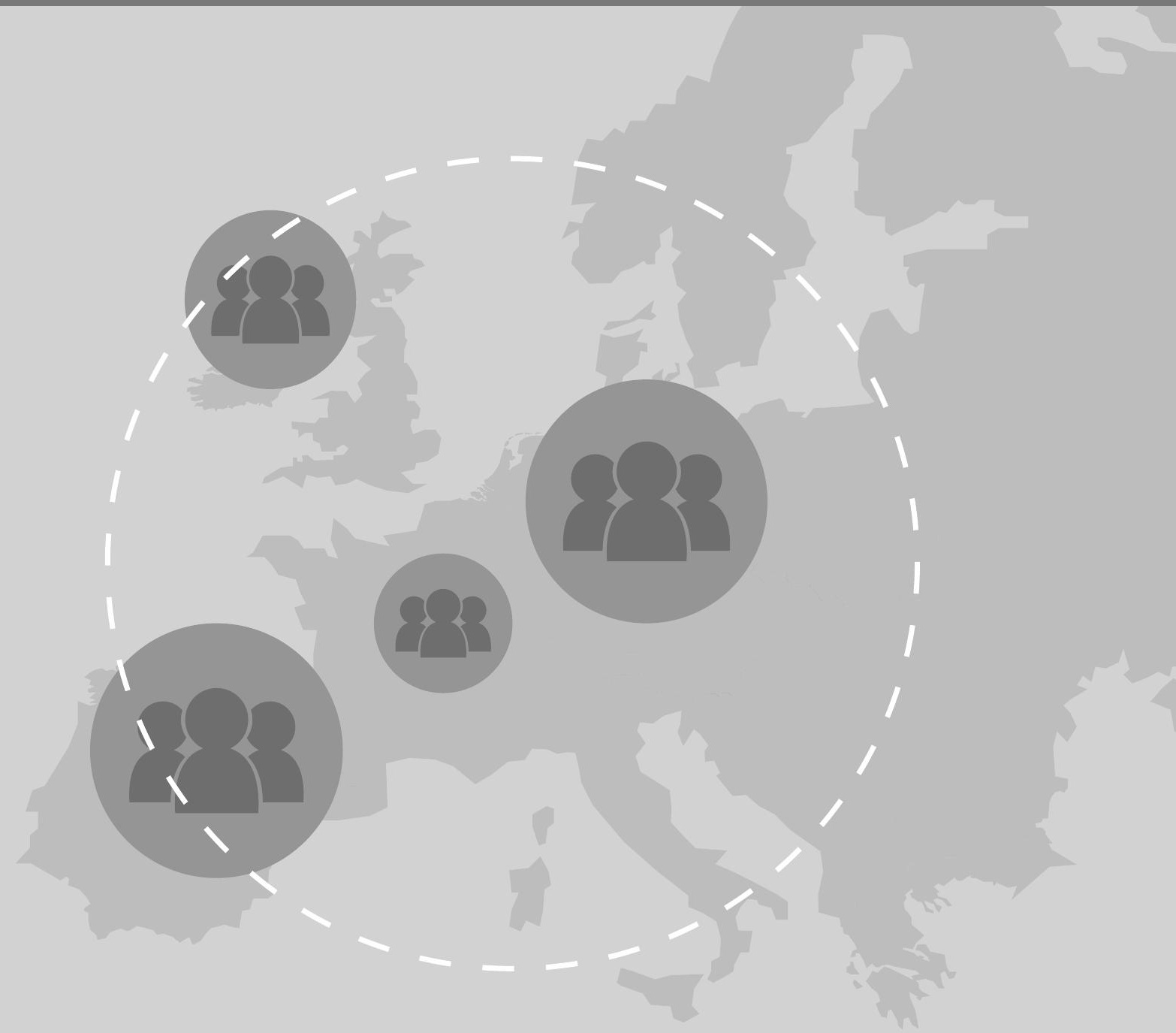




\begin{abstract}
Several rights and value based health strategies have been launched in Europe in recent years, with the aim to improve the health and well-being of populations. Citizen empowerment, people-centeredness and co-production of health are some of the key values. However, with nearly one out of two persons having a limited level of health literacy, people-centered co-production of health remains a challenge. This study aims to explore how European governments engage in citizen consultations and how they develop health literate populations and systems. Data concerning governmental practices in this regard was collected from experts in 22 European countries, using a selfcompleted questionnaire generated from a deductive thematic analysis referring to a conceptual framework integrating tree dimensions of health literate populations, ten attributes of health literate systems and five levels of citizen engagement. The outcomes revealed that most countries provide health education to support citizen engagement in health, but that fewer efforts are made to ensure the development of critical thinking and civic orientation. In terms of the development of health literate systems, most countries provide a range of options fitting the attributes outlined in the conceptual model; but many countries only partly succeed in engaging citizens in equal partnerships to improve health. The study suggests that the conceptual framework is a valid instrument for exploring citizen consultations and the development of health literate populations and systems to achieve people-centered co-production of health in Europe.
\end{abstract}




\section{Introduction}

$\mathrm{n}$ recent years, a number of rights and value based health strategies have been launched in Europe with the aim to improve the health and well-being of populations. For instance, the World Health Organisation's Regional Office for Europe launched the Health 2020 strategy, which aims to "significantly improve the health and well-being of populations, reduce inequalities, strengthen public health and ensure people-centered health systems that are universal, equitable, sustainable and of high quality" (World Health Organisation's European Office, 2012). The strategy is based on values enshrined in the WHO constitution, which states that "the enjoyment of the highest attainable standard of health is one of the fundamental rights of every human being" (World Health Organisation's European Office, 2012). In this regard, European Member States of WHO acknowledge the right to health regardless of ethnicity, sex, age, social status or ability to pay and have committed themselves to universality, solidarity and equal access as guiding values, as well as to fairness, sustainability, quality, transparency, accountability, gender equality, dignity and - most notably - the right to participate in decision-making regarding the organizing and funding of health systems (World Health Organisation's European Office, 2012). The approach is in line with other rights- and value-based health strategies, such as the European Commission's Health Strategy 2008-2013: Together for Health (European Commission, 2007) and the Council of Europe's European Social Charter (Council of Europe, 1996). Like the Health 2020 Strategy, these strategies include a focus on peoplecenteredness, co-production of health and a rights-based citizen involvement in the determination of healthcare. However, questions remain as to whether these values are superfluous and too focused on healthcare for strategies that are meant to be umbrellas for the wider public health domain (Schröder-Bäck et al., 2012).

The enhanced focus on citizens' contribution to health is closely associated with a newly emerging mode of democracy called 'monitory democracy' (Keane, 2009). It implies that legitimacy and accountability shifts from authoritarian to collaborative processes, as citizens not only demand to be better informed, but also to be involved in the processes affecting their health (Kickbusch \& Gleicher, 2012). This involvement of citizens in the contemporary health strategies reflects and stimulates the emerging democratization of health, which in turn stimulates a new form of health citizenship, in which citizens are encouraged to take both personal responsibility for health and become involved as citizens in healthcare decision-making (Kickbusch, 2009).

Different forms of public participation have received much attention in health related decision making. Abelson et al. (Abelson et al., 2003) argue that the 'deliberative paradigm' has gripped the health sector, with governments, research organisations and health authorities using deliberative methods to engage the public in values- 
based discussions about the healthcare systems. A plethora of terminologies have evolved in which terms such as civil participation, citizen engagement, public dialogue, participatory democracy and public involvement are being used interchangeably, depending on the particular context. Deliberative methods are commonly described as a hybrid between consultation and research, aiming to involve the public in decisionmaking in a meaningful way by providing an opportunity for participants to find out more about a topic, consider relevant evidence and discuss this evidence with other participants before presenting their view (Myant \& Urquhart, 2007). Common methods to achieve this goal include juries, consensus conferences, workshops or polling (Myant \& Urquhart, 2007). For instance, Rowe and Frewer suggest a new typology for public engagement mechanisms, which include four communication, six consultation and four participation mechanism classes (Rowe, 2005). In a same vein, Charles and DeMaio (Charles \& DeMaio, 1993) propose a conceptualization of lay participation in healthcare decision-making by presenting a framework based on decision-making domains, role perspectives, and levels of participation. Other examples include the Public Consultation Framework from the Irish Health and Social Care Regulatory Forum (O'Flaherty, Liddy, Tansey, \& Roche, 2011) and the Forster-Matrix for participation in the health system (Ley, 2011).

The Council of Europe regards citizen consultation as a vital mechanism to strengthen citizens' democratic rights, to make use of modern communication technology and to improve the quality of healthcare and -policy related processes (Council of Europe, 2000). It further states that it is a fundamental right of citizens in free and democratic societies to determine the goals and targets of the health sector (Council of Europe, 2000). In a similar manner the Organisation for Economic Cooperation and Development (OECD) (OECD, 2001) issued a policy brief in which citizen consultation is described as a tool to add value to policy processes, as it: 1) provides additional ideas, information and resources for making decisions, 2) meets the challenges of the emerging information society, 3) responds to citizens' expectations, 4) increases transparency and accountability and 5) builds public trust.

It is obvious that only health literate populations can make a sound contribution to consultative processes regarding health policies and healthcare. However, recent European population-based research has indicated that limited health literacy is a public health challenge in several countries, with an average of $47 \%$ of the population across European countries facing difficulties in finding, understanding, appraising and applying information to manage health (HLS-EU Consortium, 2012a). Limited health literacy is associated with reduced use of preventive services and management of chronic conditions and with higher mortality (Berkman et al., 2011). It can also lead to errors in medication use, incorrect diagnosis due to poor communication between providers and patients, low rates of guidance and treatment adherence, hospital readmissions, 
unnecessary emergency room visits, longer hospital stays, fragmented access to care and poor responsiveness to public health emergencies (Nielsen-Bohlman et al., 2004). Although the economic aspects of health literacy have not yet been widely explored, a recent systematic review estimated that the costs of low health literacy may account for $3-5 \%$ of the total healthcare costs at system level (Eichler et al., 2009). Hence, limited health competencies of populations may jeopardize the possibilities for citizens to become active decision-makers in health.

So, while the growing demand for people-centered approaches and the coproduction of health by citizens and authorities calls for new perspectives on participation, health literacy can be a critical concept. Health literacy is generally considered to be an essential skill for the $21^{\text {st }}$ century (Kickbusch, 2011). It is closely linked to literacy and entails the knowledge, motivation and competences to access, understand, appraise and apply information to form judgment and take decisions in terms of healthcare, disease prevention and health promotion to maintain and improve quality of life during the life course (Sorensen, Van den Broucke, et al., 2012). Besides, health literacy is not applied in a vacuum: society, the community and the healthcare, education and social systems all mediate the impact of skills on health (Rowlands, 2012). Thus, health literacy reflects the dual nature of responsibility of citizens and societal systems alike, as it represents the alignment of individual skills and abilities with the complexity and demands of systems in terms of what needs to be done to maintain and promote health (Parker \& Ratzan, 2010).

This paper aims to discuss how health literacy and participatory methods such as citizen consultations are pre-requisites for the achievement of the people-centered health approach that has been proclaimed by WHO/EURO and the EU in their respective strategies. It presents the results of a scoping study on health literacy and citizen, providing insights in current governmental practices to achieve people-centered coproduction of health. The scoping study was guided by a conceptual framework that will first be outlined.

\section{An integrated framework for people-centered co-production of health}

The analytical framework applied in the study encompasses three domains, as represented by the circles in Figure 12.1. The first circle represents health literate populations. A sufficient level of health literacy in the population is a prerequisite for peoplecentered co-production of health, but it is not sufficient, as co-production of health can be hampered when people are not active citizens or have limited access to health literate systems. Freedman et al. (Freedman et al., 2009) suggest three areas of importance for the development of public health literacy, which equip citizen to participate in health at societal level. 
1. Conceptual foundations, which include the basic knowledge and information needed to understand and take action on public health concerns.

2. Critical skills, which are necessary to obtain, process, evaluate and act upon information needed to make public health decisions that benefit the community.

3. Civic orientation, which ensures that "the public" remains at the center of public health literacy and includes the skills and resources necessary to address health concerns through civic engagement.

As such, the domain concerning the advancement of health literate populations implies a focus on three components: conceptual health foundations, critical skills and civic orientation.

The second circle represents health literate systems. Again, this is a critical factor to achieve people-centered co-production of health, but not sufficient: co-production of health is not obtained if patients or clients are not sufficiently health literate or if citizen consultation mechanisms are not in place to engage active citizens in the decision-making. Therefore, in order to encompass people-centered health, authorities and public officials will need to develop health literate organisations and systems to support and facilitate people to navigate health for themselves, their families and the wider community (Brach et al., 2012). According to Brack et al. this can be achieved by focusing on ten attributes that include:

1. leadership, which integrates health literacy into the organizational mission, structure, and operations;

2. integrating health literacy into planning, evaluation measures, patient safety, and quality improvement;

3. preparing the workforce to be health literate and monitors progress,

4. populations served in design, implementation, and evaluation of health information and services;

5. meeting the needs of populations with a range of health literacy skills while avoiding stigmatization;

6. using health literacy strategies in interpersonal communications and confirms understanding at all points of contact;

7. providing easy access to health information and services and navigation assistance, 
8. designing and distributing print, audiovisual, and social media content that is easy to understand and act on;

9. addressing health literacy in high-risk situations, including care transitions and communications about medicines;

10. communicating clearly what health plans cover and what individuals will have to pay for services.

The third circle represents the active citizens engaging in citizen consultations. Active citizens are also a prerequisite for people-centered co-production of health, yet it is not enough in itself as people may not be sufficiently health literate or may not be able to access non-health literate systems. For the current study it was decided to adopt the illustrative framework from Health Canada concerning citizen engagement (Sheedy, Mackinnon, Pitre, \& Watling, 2008). The framework differentiates between five levels although the boundaries between these levels are fluent and many hybrid forms can exist. The five levels include the following.

1. Informing or Educating: one-way flow of information; the public needs to know about the results of a process. A decision has already been taken.

2. Listening: one-way 'reverse' flow of information; the purpose is to gather information. Decisions are still being shaped; no firm commitment to the views collected.

3. Consulting: two-way information exchange; individuals and groups have an interest in the issue and will be affected by the outcome; input may shape policy directions/program delivery.

4. Engaging: round table discussion; Citizens need to discuss complex, valueladen issues; capacity for citizens to shape policies and decisions that affect them; shared decision making is common.

5. Partnering: citizens in the "driver's seat"; citizens to manage the process and government acts as an enabler.

By combining the three domains outlined above, a framework is created which represents different perspectives of people-centered co-production of health. Figure 12.1 also shows the intersections of the three circles. In area 4, health literate citizens act in health literate systems, yet mechanisms are not in place to enjoy full partnerships. Area 5 shows how health literate systems may be open to engaged citizens, however the quality of citizen engagement is hampered due to limited health literacy among the participating people. Area 6 shows the situation where health literate people are active in society, but the healthcare system is not equipped to facilitate the people- 
centered co-production of health. The centre (area 7) represents the optimal situation, where health literate, active citizens are encouraged by a health literate system to pursue optimal people-centered, co-production of health. It is the situation where citizens possess sufficient public health literacy (including the three dimensions of conceptual foundations, critical skills and civic orientation in Freedman's conceptualization) to take part in citizen consultations as equal partners (stage five in Sheedy et al's model (2008)) facilitated by a transparent and accessible health literate systems (matching all the ten attributes). As such, it is assumed that this "ideal" situation would enhance people-centred and co-productive health by engaging health literate health professionals as well as citizens through well-established collaborative mechanisms.

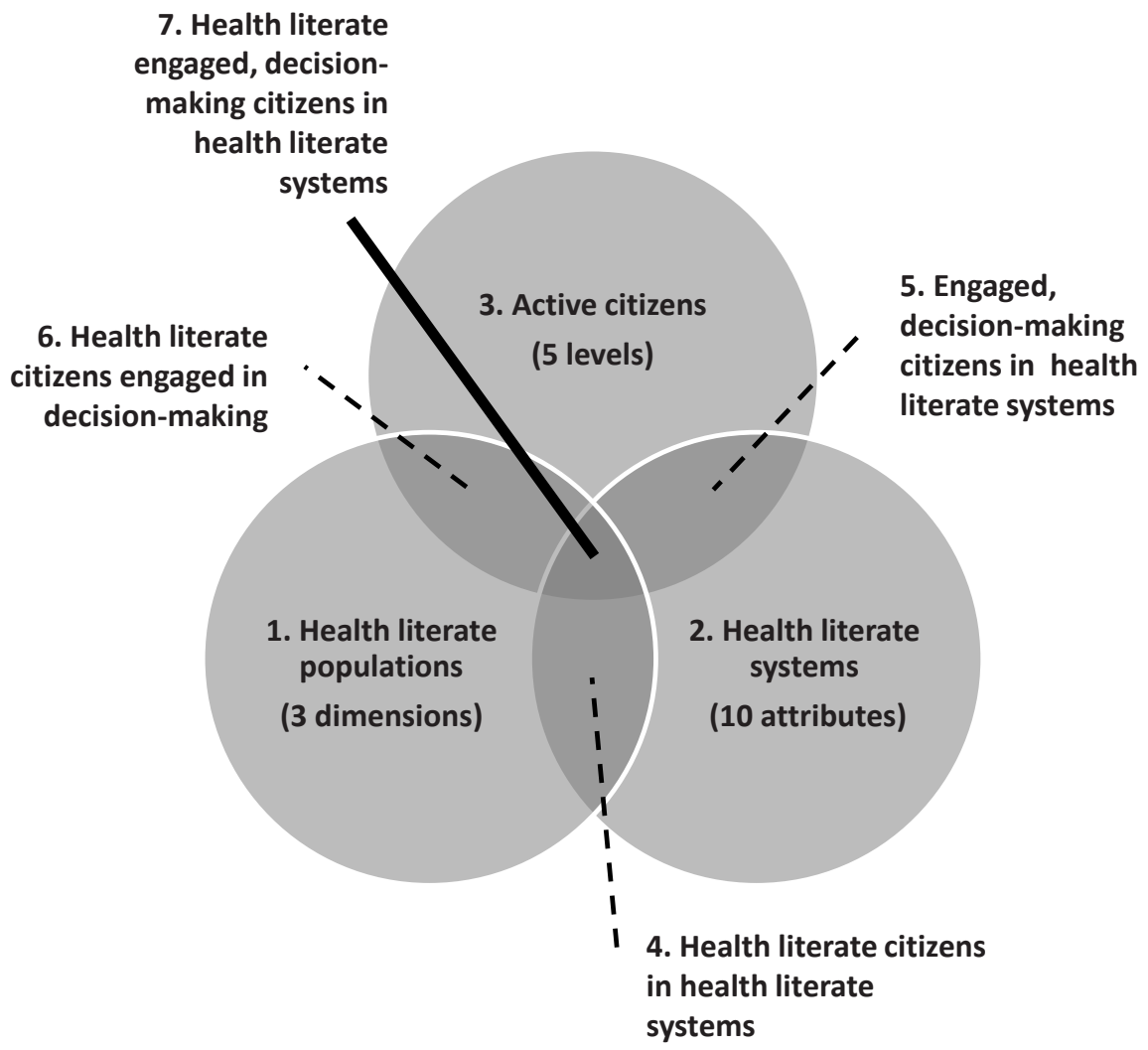

Figure 12.1 The conceptual model concerning citizen consultations, health literate populations and systems as pre-requisite for people-centered, co-production of health. 


\section{Method}

For the scoping study, use was made of the expert consultation approach. To that effect, a self-completion questionnaire was developed to facilitate a quick assessment of existing infrastructures and processes for citizen consultation and health literacy development in different European populations. This method is especially advantageous for a sample that is geographically widely dispersed (Bryman, 2012). The questionnaire included 23 open and closed items covering the topics of existing infrastructures and processes for citizen consultations and health literacy development in populations with reference to legislation, policy and practice, equality and nondiscrimination, vulnerable groups and mechanisms for citizen's consultation.

Data collection took place during the summer of 2012 and involved the distribution of the questionnaire to the national focal points of the 47 Member States of Council of Europe. A second call for participation was launched in November 2012. Initial finding from the survey were presented to national representatives during a two-day workshop in November 2012. At this occasion, the respondents were asked to provide additional information on their responses and to discuss and validate the findings. The feedback from the workshop was included in the descriptive data analysis. The answers from the open-ended questions were transcribed and practices were identified by means of a deductive thematic analysis and subsequently coded into a pre-existing coding system consisting of the conceptual framework to identify governmental practices within three main categories: 1 ) the development of health literate populations in terms of Freedmann's three dimensions; 2) the development of health literate systems according to the ten attributes of Brach et al. ; and 3) the application of the five levels of citizen consultations as described by Sheedy et al's (2008). One researcher (KS) made the analysis of 1 ) and 2), while another (CA) did the 3 ). The categories were then reviewed and compared by both researchers to ensure consistency and to identify the main results of the survey. During the analytical process, the researchers continually considered whether the analysis provided a convincing and wellorganised representation of the data corpus and the topics in focus.

\section{Results}

The data collection resulted in responses from 22 countries (47\%): Austria, Armenia, Azerbaijan, Belgium, Bulgaria, Croatia, Cyprus, Czech Republic, Finland, Germany, Hungary, Israel, Lithuania, Moldova, Monaco, Norway, Portugal, Romania, Serbia, Slovak Republic, Sweden and Turkey. Among the responding countries, eight member states also involved non-governmental organisations in the response process. 
The thematic analysis resulted in a range of practices related to every of the three main categories, however it was not possible to identify practices in terms of all of the sub-categories: 1) the three dimensions of health literate populations, 2) the ten attributes of health literate systems and 3 ) the five levels of citizen consultations. The results are summarized in detail for the three main categories.

\section{Development of health literate populations}

With reference to the dimensions of Freedman et al. (Freedman et al., 2009), the analysis indicated that the conceptual foundations of public health as mentioned by all respondents were provided through formal childhood and adolescent education as well as adult learning programmes in the participating countries. Education in terms of the development of critical skills was only marginally mentioned, but in some countries notable practices in that sense were given, including health education linked to the development of general life skills. Concerning civic orientation from a health literacy perspective, it was revealed how in some countries target groups were involved in decision-making and influencing content of health initiatives and programmes by active participation in defining horizontal issues as well as in concrete policy initiatives, like for instance the development of a child health strategy.

"Health Education is one of the services provided by the School Health Services of the Ministry of Health. It is provided to all schoolchildren of primary and secondary education (6-18 years) on various topics, based on an age specific program, by school doctors and health visitors. Each program (harmful effects of smoking, puberty, home safety, HIV/AIDS, nutrition, prevention of heart diseases, children rights etc) is developed centrally at the level of the Ministry of Health, health professionals are appropriately trained and relevant material is provided".

"For example, children and young people are involved in the implementation of the child health strategy through the involvement of representative of youth organisations".

\section{Development of health literate systems}

Notable governmental practices to develop health literate systems were seen for most of the ten recommended attributes of health literate organizations. In terms of leadership, health (literacy) was dealt with at the highest level and secured by law and constitution. In most cases, designated ministers for health and education were in charge of ensuring information, training, education and opportunities for engagement of the public in health.

"The Ministry of Health, namely the Directorate-General of Health, works in partnership with the Ministry of Education and Science and municipalities in designing and distributing health information". 
Whereas planning, evaluation, patient safety and quality improvement, formed part of general healthcare management, a particular focus on health literacy in associations with these dimensions was not often implemented. Although health education was widely taught as part of capacity building in the education of health professionals, an explicit focus on health literacy as a topic was marginal and efforts to develop a designated health literate workforce were few.

The [country, ed.] Center for Medical Simulation MSR was established in 2001 and is dedicated to improving both medical and human-relation skills of healthcare professionals. One of the things performed are simulation courses in "Communication Skills in Patient-Physician Encounters" for medical students. This is learned through simulation with actors posing as patients with complex scenarios. This is one example of how to try and improve HCPs communication skills, as mentioned in the workshop. Attending a course like that is mandatory in some medical schools.

Concerning the attribute of people-centered health information and services, a considerable number of countries conveyed experiences in engaging patients and citizens. The methods used to that effect differed from providing one-time opportunities for consultations and hearings to establishing long-term boards and panels involved in decision-making. The issue of meeting the needs of populations in spite of various health skills without stigmatization was encountered by several countries. Governmental practices included measures to actively targeting hard-to-reach groups by providing translations and material that was easy to understand. The attribute of confirming interpersonal communication and understanding was realized by some countries through 'teach-back' practices and patient education campaigns.

"[Name of programme, ed], is an initiative of the Ministry of Health, which aims to meet the needs expressed by citizens in health, helping to expand and improve access to services and rationalize the use of existing resources by routing in a more appropriate way the users towards National Health Service. It offers screening, counseling and referral in disease situation, accessible via telephone or chat (people with special needs); it also provides therapeutic counseling to clarify issues on matters related to medication".

While most often references were made to the legal aspects of the provision of easy access to health information and services, such as the constitution, law and other legal instruments ensuring the right to access to health, some participants in the study questioned whether the equal access was actually achieved in practice and emphasized that efforts were needed to ensure the protection of this particular right.

The Director General of the Ministry of Health declared that by the year 2013, all medical facilities-professions must be able to provide services in 5 main 
languages spoken/written in the [country, ed]. ... This directive will be followed by surveillance and applies to all practitioners and facilities, including signs and written material".

Most commonly, practices concerning easily understandable information design were illustrated with reference to web-based platforms for sharing information and creating opportunities for interaction between citizens/patients and the systems. Although no data covered communication in high-risk situations, reference was made to the hardto-reach population groups which are particularly at risk of having limited possibilities in terms of health protection. Lastly, the attribute of clear communication on payment for services was an issue for only a single country.

The new Healthcare Act ... sets down the quality of care and patient safety: each healthcare unit shall produce a plan for quality management and for ensuring patient safety. The National Institute for Health and Welfare produces information, available at websites, about accessible healthcare services and the quality of healthcare services. There is need to develop and improve coordination on information about available healthcare services and their quality as a basis for choosing the caregiver.

\section{Facilitation of citizen consultations}

Based on the Health Canada framework for citizen consultation (Sheedy et al., 2008), governmental practices were identified for all five levels of citizen consultations. However, in most countries the reported practices were largely associated with the levels one and two concerning the provision of information, information sharing and discussions. Very often, these consulting mechanisms included online portals through which citizens could receive information (level 1 ) and voice their opinion on healthy policies and the provision of healthcare (level 2). Telephone hotlines were also an important mechanism for engaging with the public (level 2).

The telephone hotline [name of initiative, ed.] was established in 2004 to identify problems in the [country, ed.] healthcare system and to solve them immediately on site and in the fastest way possible. Anyone ...call the ...hotline and can provide information on any kind of problem or question regarding the health system. Operators responding to the calls are health professionals, who have comprehensive knowledge of the way the health system functions, with sufficient knowledge on health legislation. The operators do not only provide and answers and solutions to the problem, they also keep records of any kind of questions, problems, criticisms, suggestions and requests. Citizens can use the hotline for the following issues:

- $\quad$ information on any matter related to the functioning of the health system; 
- submission of requests, criticisms and suggestions about the health system;

- conveying of problems they face at any stage of the system while making use of health services.

The analysis further identified a few mechanisms which formally included the public as an advisor to the government on public health and care related matters. This usually took form through representation of the public in panels and discussion boards on health related matters (level 3).

The[country, ed.] government decided in 2012 to introduce 10 health targets for [country, ed.]. These were developed by the so called Federal Health Commission, the highest political body for health policy in [country, ed.]. This body consists of representatives of the national, regional and local governments, social insurances, healthcare institutions as well as patient and doctor's representatives. Notably, the development of the health targets was based on a consultative process with citizens. Through an online platform, citizens were invited to voice their opinion on the content of the health targets. Between May and August 2012, almost 4500 citizens participated in this process. The answers and viewpoints were collected, appraised, discussed and ultimately used for the development of the ten [national, ed.] health targets.

In contrast, only very few examples were reported from the countries for the levels 4 and 5 , in which co-decision making rights are granted to citizen. A few examples highlighted that in the areas of quality assurance and patient satisfaction, civil society was included in committees with decision making power (level 4). No examples were reported for level five, in which citizens would act as equal partners with the government in the discussions and the respective decision making process.

\section{Discussion}

In order to 'significantly improve the health and well-being of populations' by means of people-centered co-production of health (Kickbusch \& Gleicher, 2012; World Health Organisation's European Office, 2012) as a gateway to democratizing health, it is necessary to explore new mechanisms to enhance citizen's involvement in the coproduction of health. The current study introduced a rationale for the investment in health literacy and citizen consultations as pre-requisites for this development.

The study starts from the rationale that citizen consultations are a vital mechanism in modern democratic societies (Council of Europe, 2000) and that scaling up citizen 
consultation to the higher levels would be beneficial for all stakeholders involved (Sheedy et al., 2008). Despite the fact that various practices were identified to encourage citizen consultations, the results from our survey show that they are mainly limited to informing and educating and to gathering information. For example, as citizens and patients are legally entitled to information about healthcare and health policy processes, the respondents in our survey reported various communication channels through which information was made publicly available. Furthermore, citizens were also able to voice their opinion and their discontent (complaints) if unsatisfied with ongoing processes through various complaints mechanisms. In contrast, higher levels of involvement, implying that citizen consultation unfolds its full potential through discussions, engagement and partnerships were not often mentioned by the respondents, despite the fact that healthcare and health policy processes could be actively shaped and supported by citizens through such mechanisms. Indeed, as this form of consultation requires a more substantial change of existing systems and procedures, the feasibility of implementing consultative processes at these levels requires a careful analysis of available capacities and willingness to support the process.

The results of the scoping study also provided some first-hand insights into how member states work to improve the health literacy in populations and within systems. It revealed that health education has been institutionalized and forms part of formal education and life-long learning, creating a profound basis for the development of health literacy in populations. However, information and awareness-raising remain the predominant approaches and less emphasis is given to interaction and engagement of citizens and to the critical skills and civic orientation building which are also part of health literacy. Moreover, the mechanisms available for consultation are often characterized by a top-down, rather than a people-centered approach, and are more made for people than developed with people. This corresponds with the discrepancy that is seen between the apparent outcomes of formalized health education efforts and the finding of the European Health Literacy Survey that on average $47 \%$ of the population in Europe faces difficulties in managing health due to their limited health literacy (HLSEU Consortium, 2012a). While information dissemination remains important (Nutbeam, 2000b), improving the health literacy of populations requires more than just that. In today's knowledge society, health professionals and decision-makers need to re-define their role to become 'knowledge brokers' (Sorensen \& Brand, 2011b), who can facilitate proper knowledge transfer to citizens and colleagues, and hence, improve the advancement of health literate populations.

In this regard, an important contribution can be made by the development of health literate systems. The results of the survey with regard to this aspect illustrated that there is a pull towards improving the systems towards being more health literate, and that capacity building to that effect is taking place, although targeted efforts re- 
main implicit, rather than explicit. The survey results showed that both governments and non-governmental organisations take on leadership roles in promoting health literacy, and that structures are being established, which integrate health literacy as a value. Yet, it was also seen that the development of structures, guidelines and laws to secure health protection may not always reflect the reality, and that parts of populations are less well served than other parts in terms of engaging in people-centered health. Whereas practices exist to address all ten the attributes that are relevant for health literate organisations, they were generally not elaborated explicitly. On the other hand, the study does show that European countries have begun to prioritize the development of health literate systems and that a few countries are forerunners in terms of how health literacy can be strengthened at national levels through deliberative approaches.

The discrepancy between what is offered through educational programmes and the apparent lack of competencies also raises the question of what can be done to secure a better match between civic partnership, population health literacy and health literate systems. On one hand, more opportunities are needed for people to develop their critical skills and engage through civic partnerships in health. On the other hand, efforts must be increased to ensure that systems are equipped to comply with people's needs and to match their levels of health literacy. Opportunities should be provided to ensure stronger consultations with people in general to facilitate better and more appropriate services. When the three domains are aligned, quality of communication, actions and outcomes are likely to be enhanced to the benefit of peoplecentered health.

The current study reflects on the ongoing discussion on how to engage 'ordinary' citizens in public deliberations on policy issues. This is a topic of increasing importance in democratic theory and practice (Guttman, 2007). While it is often argued that new media and technologies may have a significant and positive impact on democratic communication (Tambini, 1999) through embracing e-health and web-based means, this may not be sufficient. Structural changes in governance are needed as well to provide opportunities for democratization (Pieterse, 2001). Yet, expert-bias may be a barrier that few are aware of concerning people-centered co-production of health. In this regard Bess et al. (Bess, Prilleltensky, Perkins, \& Collins, 2009) state that participation may be better understood as a continuum ranging from non-participation to political engagement and provide the example that participation in the realm of research is often framed in terms of active or citizen participation in which individuals already feel empowered and ready to commit to a course or action. However, the authors assert that very few individuals are ready for political engagement. They recommend working with participants to create a shared agreement around participation that is inclusive and provides an opportunity to reflect on how they would like to participate, because 
the blurriness, which was also seen in the current study, stems from the way experts or researchers define participation. So, participants are not unable or unwilling to participate, but may not do so in the way that is envisaged by experts or researchers. This observation impacts the understanding of the conceptual framework outlined in the current paper. The three main domains should be understood as embracing continua of health literacy in populations, health literate systems and participation in deliberative settings, rather than the either/or situation described by the bold lines of the circles in Figure 12.1.

\section{Limitations and implications}

The conceptual framework serving as the basis for the study presented in this paper builds on foundations that have not been validated explicitly. However, the rationale in the three main categories is considered representative for the overarching discourse in the respective fields of health literacy and public participation. Some respondents in the study emphasized that although the survey focus was on health literacy, it was of more importance to strengthen the determinants of health and the structures and opportunities for living a healthy life and making healthy choices. Generally, it was also emphasized that when engaging in informed and shared decision-making on health, various important factors should be taken into account, such as culture, traditions, education, social and economic status, advertising and habits.

Whereas it was possible to identify examples, attributes and levels for the different dimensions of the conceptual model, it should be acknowledged that the overall data set related to governmental practices was fairly limited. A more systematic appraisal concerning population health literacy, health literate systems and of the effectiveness and efficiency of existing deliberative approaches, including higher-level practices, would be beneficial. Nevertheless, the finding that practices among 22 countries could be identified illustrating the importance of health literacy and public participation in people-centered co-production of health in the process of democratizing health is an indication that the conceptual model is useful to structure the thinking on the way health literacy, health literate systems and citizen participation impact on peoplecentered co-production of health.

\section{Authors' contributions}

Introduction: KS, CA.

Method: KS, CA.

Results: KS, CA.

Discussion: KS, CA, SVDB, HB. 


\section{Acknowledgements}

The study on governmental practices related to health literacy and citizen consultations on the protection of health was commissioned by Council of Europe and conducted by Kristine Sorensen and Aluttis Christoph, Maastricht University in close collaboration with Mohruba Garfazada and Thorsten Afflerbach, Council of Europe. 
If one is truly to be successful in leading a person to a specific place, one must first and foremost take care to find him where he is and begin there.

Søren Kierkegaard 


\section{CHAPTER 13}

General discussion

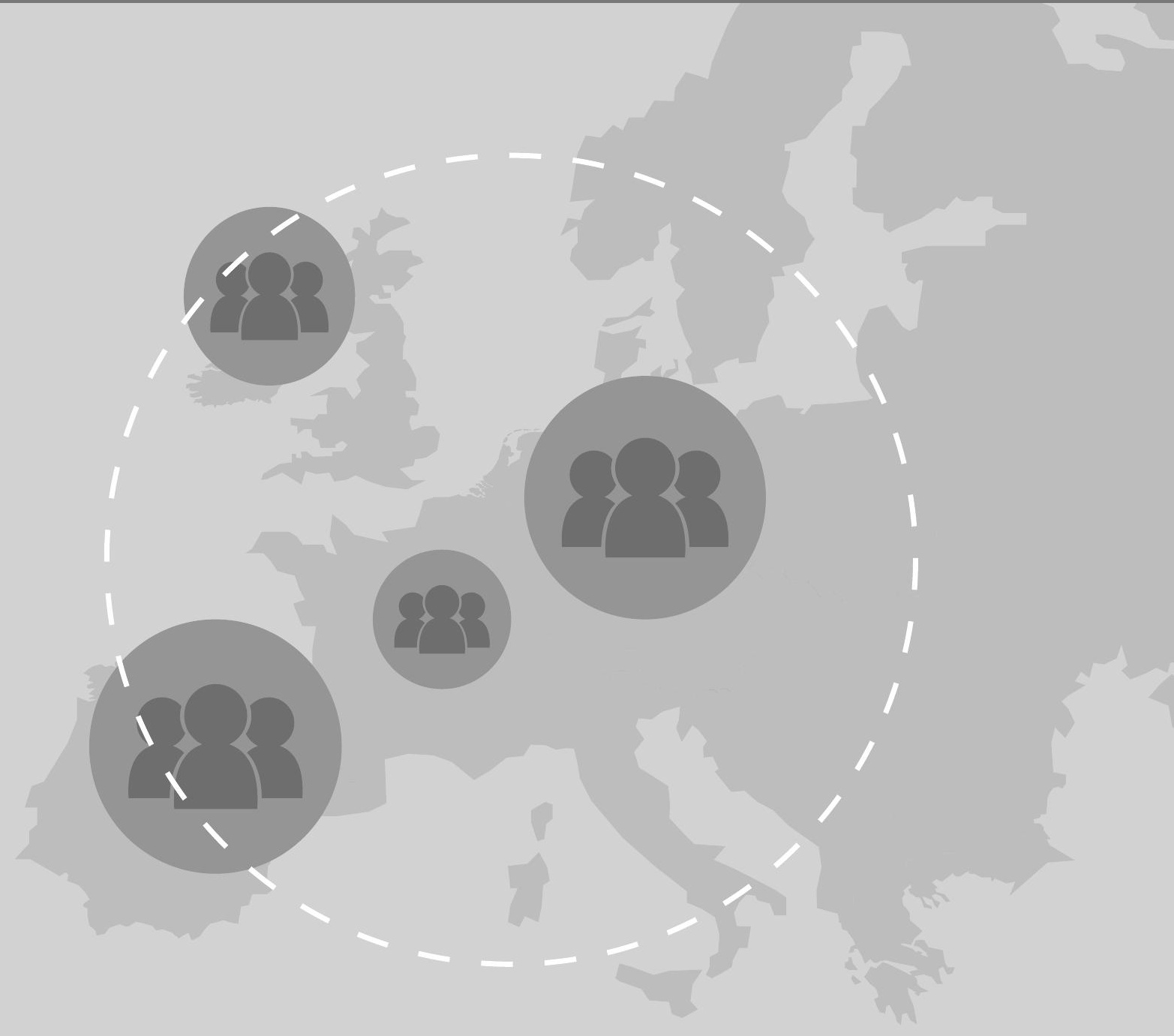




\section{Introduction}

he research in this dissertation aimed at exploring how health literacy as a contemporary challenge to public health could be defined, measured and advanced in Europe. In this chapter, the main findings will be summarized and elaborated in terms of international literature on health literacy and the methodological limitations. Additionally, priorities for future research and further advancement of health literacy in Europe will be presented in the concluding remarks.

\section{Overview of main findings}

The studies were grouped in three parts: 1) defining health literacy 2) measuring health literacy, and 3) advancing health literacy as part of developing health literate systems, health literate businesses and health literate societies. The research resulted in eleven key outputs, which are illustrated in Figure 13.1 below:

\section{Health literacy in Europe}
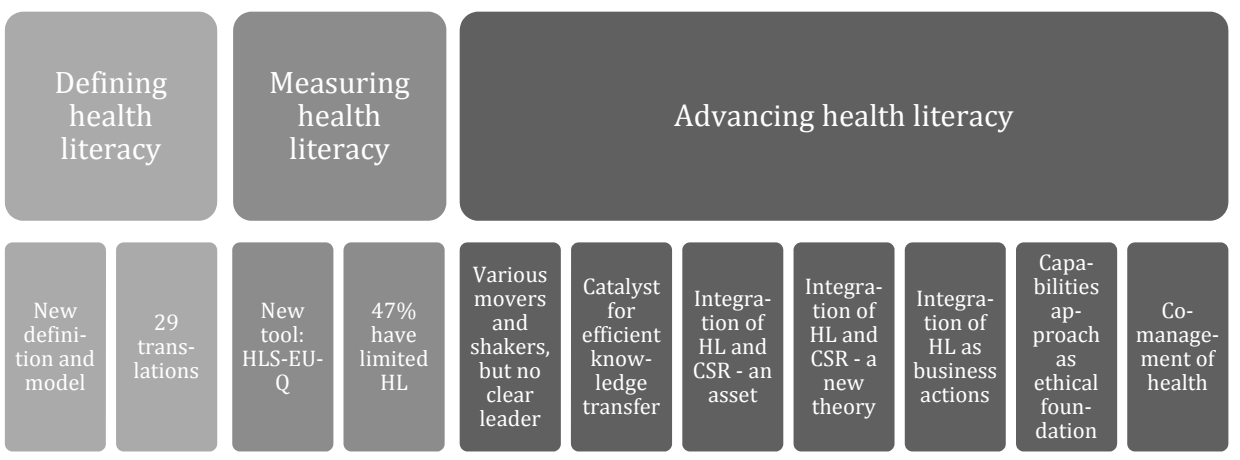

Figure 13.1: Overview of main findings in terms of Health literacy: a neglected European public health disparity

Notably, the current research has provided a new 'all-inclusive' definition and conceptual model of health literacy, which can be interpreted from the perspectives of citizens as well as from the perspectives of health systems. The term 'health literacy' proved a challenge to translate within the international and European context, hence, a study was made to explore translations. Furthermore, a European Glossary representing 29 languages could be introduced. Concerning the challenge of measuring health literacy in Europe, a questionnaire, the HLS-EU-Q, was developed on the basis of the new definition and conceptual model to measure health literacy in a selection of 
EU Member States. Subsequently, a survey was conducted in eight countries. The survey indicated that $47 \%$ on average had limited health literacy, although, the results varied between the participating countries (29\%-62\%). Concerning health literate systems a case study from Denmark with reference to movers and shakers in the field of health literacy illustrated a wide range of stakeholders involved; however it also disclosed a vacuum of leadership as none could be classified as designated front runners in advancing health literacy. A specific focus on health professionals in the field of public health genomics revealed that they have to pursue new roles in communication with patients and colleagues. It was argued that health literacy can act as a catalyst for efficient and transparent knowledge transfer and that health professionals ought to consider themselves as knowledge brokers to support better communication when dealing with complex and innovative matters such as for instance public health genomics. Concerning the development of health literate businesses, the research demonstrated how health literacy was an asset for corporate social responsibility by moving the focus from the fitness room to the strategic corporate opportunities determined in the boardroom. A Blueprint for Business Action on Health Literacy was presented to influence social practices concerning health at work. Lastly, the aspect of developing health literate societies was scoped in terms of ethical perspectives in the stance of social determinants, quality of life, justice, human rights and the capability approach for human development. In addition, a scope study contributed with a framework on how health literacy can support the development of health literate populations and systems to increase people-centered, co-production of health through the means of citizen consultations.

\section{Defining health literacy}

The critical review in the current study of health literacy definitions and conceptual models resulted in the development of a new integrated definition and conceptual model, which captured the most comprehensive evidence-based dimensions of health literacy. The proposed 'all inclusive' definition is adaptable and includes the public health perspective in addition to the individual perspective. It also embraces a broad span of health from healthcare to disease prevention and health promotion. By integrating existing definitions and conceptualizations of health literacy into an encompassing model outlining the main dimensions of health literacy as well as its determinants and the pathways to health outcomes, the new model has a heuristic value in its own right. More importantly, however, it can also support the practice of healthcare, disease prevention and health promotion by serving as a conceptual basis to develop health literacy enhancing interventions and feasible measurement tools as encouraged by for instance Pleasant and McKinney (Pleasant \& McKinney, 2011). Whereas the review was performed end of $\mathbf{2 0 1 0}$ more literature has been published on the identification of health literacy as a multidimensional concept. Notably, attention has been 
given to the construct of critical health literacy defined by Nutbeam (Nutbeam, 2000b), which is only implicit embedded in the HLS-EU definition as the competency to access, understand, appraise and apply information. Chinn has analysed critical health literacy more rigorously as a social asset that helps individuals towards a critical engagement with health information (Chinn, 2011). However, Sykes et al. points out that recently, critical health literacy has become restricted to a higher order cognitive individual skill rather than a driver for political and social change. They argue that in order to retain the uniqueness and usefulness of the concept in practice efforts should be made to avoid this dilution of meaning. The first versions of the conceptual model included a box labeled 'literacies' embracing other literacies such as civic literacy, financial literacy, internet literacy etc.; but it was later deleted for simplicity of the final model; while it is still mentioned in the text. However, along these lines, a recent study by Frisch et al. has explored how other literacies are closely linked to health literacy (Frisch, Camerini, Diviani, \& Schulz, 2012). Although, it is considered a strength that the present thorough review was conducted on the basis of existing peer-reviewed literature; it at the same time possess a limitation since no citizens, patients or health professionals were actively involved in the development of the new definition and conceptual model apart from the inter-disciplinary stakeholders in the HLS-EU Consortium. Active participation could have been achieved by applying another method such as concept mapping, focus groups or in-depth interviews. The added value may have been the development of a less expert-biased definition and conceptual model.

The dissertation outlines a novel collection of 29 health literacy translations presented as a European glossary. Generally, the translation of health literacy has only scarcely been researched. In addition, as there is no universal agreement of the definition of health literacy and, partly as a result, translation of the concept across languages is fraught with difficulty (Pleasant, 2012). Further, there is no universally equitable means to translate the concept of 'health literacy' into multiple languages. The conceptual understandings of health literacy reported from around the world have far exceeded the literal understanding of both 'health' and 'literacy'. As a result, accurate translation between languages is increasingly problematic (Pleasant, 2012). Although, several sources were included in the analysis of translations, the glossary may not cover all existing translations. Furthermore, the glossary does not direct any specific solutions for every country; rather it provides an overview which can ensure that health literacy is not lost in translation. Nevertheless, the glossary served its purpose recently, when the Danish research cluster (see chapter six) consulted the Danish Language Council to reach consensus concerning the Danish translation of health literacy. With reference to the glossary included in the dissertation combined with in-depth studies of the previous use of the term in Danish; it was decided to formerly recommend the term 'sundhedskompetence'; instead of any of the other five to eight Danish 
terms that were being brainstormed in the consensus seeking process (Danish Language Council; personal communication). It is the hope that the Glossary in a similar way may be of assistance in terms of clarification in other languages, too.

The focus on terminology concerning definitions and translations has often been a hindering factor for measurement and actions in the field of health literacy. With the contribution of the new 'all inclusive' definition and conceptual model; as well as the overview of translation opportunities; the barriers have been diminished; terminology discussions at length ought not to jeopardize attempts to improve health literacy in populations anymore.

\section{Measuring health literacy}

Whereas, current available tools to measure health literacy do not capture all aspects of the concept identified in the literature, there is a need to develop new tools to assess health literacy in a way that reflects health literacy definitions and accompanying conceptual models for public health. Therefore, by following a concept validation approach, scales were developed to assess the dimensions outlined in the conceptual model developed by the HLS-EU Consortium, which resulted in the new tool: HLS-EUQ. However, the development of the HLS-EU-Q faced some limitations, which are worth noting. In practice, the validation process was hampered by a limited budget to ensure cultural adaptation and statistical validation in all the countries that participated in the HLS-EU survey. Instead, focus groups were conducted in three countries and field tests in two countries. However, as the impact of the feedback resulted in considerable changes in the design, it can be questioned whether validation studies should in fact have taken place again in terms of testing the final version used in the HLS-EU survey. Essentially, the HLS-EU survey represents the first time data on health literacy in Europe and as such it can be considered a pilot in itself. It is envisaged that with an increase in the evidence base concerning the HLS-EU-Q, changes will be suggested to refine the measurement in the future. In addition, the quest for efficient health literacy measurements goes on. A new ongoing study aims to develop a tool-box for researchers to choose an adequate tool for different research purposes. So far, more than twenty measurements have been identified (McCormack et al., 2012). Yet, it is a challenge to ensure that all dimensions are captured in one golden standard (Pleasant et al., 2011) and generic tools concerning specific diseases, target groups etc. may be justified (Buchbinder et al., 2011).

The HLS-EU survey measured the health literacy in eight EU Member States. Surprisingly, an average of $47 \%$ across the eight countries possessed limited health literacy. The levels varied within the domains of healthcare, disease prevention and health promotion; and differed considerably between the countries. A social gradient was detected, which indicated that limited health literacy is not only a challenge for marginalized populations, but should be considered a general public health threat in some 
countries in Europe. This kind of first time data can support decision-makers and health professionals to take appropriate measures to improve the skills in the population as well as enhance health literate systems (Parker \& Ratzan, 2010). Previous research has shown that health literacy levels differ depending on the tools used (Buchbinder et al., 2011). Yet, the overall message is consistent of limited health literacy being a burden for patients and healthcare systems (Berkman et al., 2011; PaascheOrlow et al., 2005b). By some it is even called the silent epidemic (Clark, 2011). Whereas the HLS-EU survey provided data on health literacy in eight countries, many more countries in Europe ought to measure health literacy as well. The scope of the current study was limited due to its financial impact of self-financing in combination with available EU funding. However, it is envisaged that in a long-term perspective the HLS-EU survey will be anchored in a sustainable manner either as part of the European Commission's Eurobarometer monitoring system or within the action framework of the World Health Organisation's European Office. Perhaps, considering the recent exponential growth it may even be a global platform that continues to monitor the state of the art of health literacy at country level.

Often the discussions concerning measurement fall back on 'the hen or the egg' dilemma. It takes evidence to convince decision-makers about health literacy as a public health disparity and in turn, the ability to create the evidence is grounded in the political will to provide the necessary funding to provide the state of the art. The comparative study presented in the dissertation has mobilized action at national and European levels. Since the European Health Literacy survey took place, more countries have collaborated with the HLS-EU consortium to conduct national studies or studies in subpopulations as for example in Belgium, Denmark, Germany and Israel. Yet, several attempts in other countries were blocked due to lack of public funding and it is clear that in order to progress further, it will be necessary for both public and private stakeholders to recognize that health literacy is a neglected European public health disparity, which needs to be dealt with in combined efforts.

\section{Advancing health literacy in Europe}

While the HLS-EU survey did not include any of the Nordic countries, it was decided to explore the future opportunities for health literacy research, policy and practice with reference to Denmark. Based on a stakeholder analysis the aim of the research was to identify movers and shakers who could influence the developments towards an enhanced engagement in health literacy. Although the study revealed a variety of interdisciplinary stakeholders, the impact seemed marginal and a power vacuum and lack of leadership in Denmark was apparent. Interestingly, the health sector played a minor and almost an invisible role in comparison with other actors such as municipalities and regions. A considerable barrier seemed to be lack of ownership leaving a potential maneuver room for stakeholders who wish to play an active role in the implementa- 
tion short term and long term. Only few studies exist apart from the HLS-EU survey concerning health literacy at national levels in Europe (Fransen, Von Wagner, \& EssinkBot, 2011; J. Wang et al., 2012) and none has focused on the stakeholder aspect. Yet, it is essential to explore the aspect further to enhance efforts and bridge the health literacy divide identified in the HLS-EU survey. The current study was limited by the scarce amount of peer-reviewed references available in terms of health literacy. The mapping exercise did not include an in-depth discourse analysis of the context wherein health literacy was mentioned. Rather, the stakeholder diagram represents an overview of the movers and shakers available with a potential to influence the field in the future. In turn, it is recommended that this scoping study is followed up with more profound stakeholder analyses building on primary sources such as in-depth interviews, focus groups or other means. Essentially, the study can be performed in more countries in Europe to distinguish stakeholders at national and European level with the aim to foster collaboration and knowledge sharing across borders.

In addition, the study concerning health literacy and public health genomics eluded on the role of health professionals to shape health literate systems. The study focused on the capacity of health literacy as catalyst for knowledge transfer among health experts. It discussed health literacy applied to new frontiers such as the complexity and novelty of public health genomics, which poses a challenge for effective and responsible translation of information to the benefit of population health. The study emphasized that a new characteristic of health professionals is encouraged, which relates to expert roles exercised as knowledgebrokers and "nudges" to temper information for medical colleagues and patients alike. Notably, genome-based health literacy is challenged by the question of which information is relevant for the individual, for what purpose and at what time during the lifespan (Syurina, Brankovic, ProbstHensch, \& Brand, 2011). Furthermore, it should be recognized that health professionals and patients may view aspects of the same "treatment" very differently. There is no privileged vantage point from which to decide who is right and who is wrong, which leads to the importance of good doctor-patient communication that needs to be as jargon-free as possible, be empathetic and bridge educational, social and age related boundaries (Lapsley, 2013). Although both studies included in this section are smallscale studies, they essentially contribute with the findings that the health literacy field is not only for health professionals; conversely, a wide range of stakeholders are involved and ought to be mobilized to tackle limited health literacy in populations. In addition, there is demand for health professionals to be pro-active knowledgebrokers, not only in the communication with patients, but also in their relations with colleagues to ensure a responsible and efficient communication. Solutions need to be identified to mobilize health-literate professionals in all involved sectors. 
Considerable efforts have been invested in exploring health literacy as part of business action. In the current research health literacy was argued as a strategic asset for corporate social responsibility. A case study on business practices concerning health at work eluded that although health at work a dominant feature, specific health literacy efforts were scarce. Whereas risks and preventive measures are regulated and internalized in strategic management, health activities are primarily regarded and organized as add-on, nice-to-have projects. In return, a new Blueprint on Business Actions on Health Literacy was developed to bridge the gap and engage businesses in health as part of corporate social responsibility. The conceptualization of health literacy and corporate social responsibility is in line with the global trends in both fields. However, the case study on businesses practices faced some limitations in order to fully illustrate the current state of the art. Only half of the companies contacted took part in the study and a majority of the companies were involved in health or the health sector one way or another. Hence, the representation of non-health related businesses was marginal. Yet, the richness of the interviews with the key informants were sufficient to provide a profound understanding of the priorities that companies make in terms of contributing to a healthy workforce. It is encouraged that future research explore the role of health and corporate social responsibility further, in particular with reference to the implementation of the new Blueprint in order to monitor progress on health literacy among employees as well as the measures that businesses establish to meet the health demands. Referring to European and global societal strategies, health is becoming more and more important for the private sector. Yet, it was evident that businesses do not yet fully embrace health as a core business value. The endorsement of the Blueprint of Business Action on Health Literacy by the European Commission and the launch in the European Parliament will hopefully progress the developments for more companies to consider their crucial role in health at work and essentially in terms of healthy living in general.

Concerning the development of health literate societies, the ethical scope study explored how the normative context of health literacy is relevant for policy, research and practice. Although ethics and health literacy have only been scarcely researched, this study illustrates how health literacy is closely associated to aspects of social justice and thus health literacy is playing a key role in advancing health and human development. An ethical framework which integrates the human development perspectives of Martha Nussbaum's capabilities approach with social justice theories encompasses the real and positive freedom for citizens and societies to be involved in promoting and maintaining health and well-being in dual responsibility. Such an ethical framework can be applied by policy makers and health professionals when engaging citizens, governments and societies at large in the investment of strengthening health literacy as normative social practice. In this respect, health literacy can be a game changer in terms 
of closing the gap of ethical concerns related to health inequalities, well-being and equity. However, by drawing on the ethical conceptualization of the capabilities approach, conceptualizations of social justice and equity follow but one modern strand of thought in political philosophy. Other well developed theories of justice exist as for instance Daniells (Daniells, 2008) who might argue the case differently. Thus, further research work that is also critical of the capabilities approach can be done exploring how the (normative) concept of health literacy is supported or rejected from philosophical perspectives.

The study on health literacy and public participation provides a new conceptual model with reference to the aim of creating people-centered, co-production of health as outlined in several international health strategies. The model indicates that health literate populations in combination with health literate systems and efficient citizen's consultation mechanisms, only reach an optimal fit when all three perspectives are developed. The model was applied as analytical framework in a pilot study on health literacy and citizen's consultations; which revealed that although societies provide formal education, emphasis is put on the development of conceptual (health) foundations and less on the development of critical competency and civic orientation. Some health systems have integrated attributes that encompass health literacy friendly initiatives; however, there is still a long way to go before it is prioritized as an essential part of the services. In addition, some countries showed examples of citizen consultation; yet none reached levels were true partnership could be extracted. For the societies to become more health literate; a normative change is needed and governmental actions should accordingly be coordinated to meet the demands.

\section{Health literacy: the neglected European public health disparity}

Essentially, the three parts of research presented in the dissertation reveal an intuitive understanding for the importance of health literacy; yet they also illustrate the divide existing in Europe presently. Some Member States in the European Union are aware of their health literacy status through, for instance, the European Health Literacy Survey, where for others the challenge of limited health literacy in their population is still neglected. While a wide range of stakeholders may be aware of the concept of health literacy or have become aware during the last years' European activities, the political ownership and leadership in terms of advancing health literacy at Member State level as well as at European level is still overlooked or only partly under development. In the efforts to create health literate systems, businesses and societies, the studies included in this dissertation generally disclose health literacy to be a new concept, which has to prove its worth in the European context. The invisibility and lack of knowledge regarding health literacy and its consequences for healthy living and quality of life among professionals and decision makers seemed to be a bottleneck for further progress. Yet, it is also the impression that the increased focus on health literacy through the work of 
the HLS-EU Consortium and its collaborating partners has formed a tipping point towards an exponential growth in activities. Hence, it can be concluded that the European added value of the research is already present, although it is presently, unevenly distributed.

The European health literacy divide where almost one in two possesses limited health literacy calls for action. To overcome this widely neglected European public health disparity, two complementary objectives are essential in the future and should underpin all efforts, namely the aim of creating health literate populations as well as health literate systems in Europe. Only when both objectives are being considered it is possible to align the competencies of the citizens with the demands of the systems to create a more efficient match in terms of interaction and people-centeredness. Notably, as Alvin Toffler stated: 'The illiterate of the $21^{\text {st }}$ century will not be those who cannot read and write, but those who cannot learn, unlearn and relearn' (Toffler, 1970). Hence, the detected neglect of health literacy in many European countries must not lead to neglect to act. Health literacy is a cross-cutting issue, which addresses many current topics on the European health agenda such as communicable, noncommunicable and chronic diseases, cross-border healthcare, use of new technologies, self-management etc. The evidence base need to be further established for the whole of Europe and the concept and measurement integrated in European research, policy and practice. A partner in the consortium wrote to me when the HLS-EU project formally finished: "This is not the end, it has only just begun". I agree with her. The European endeavor to overcome limited health literacy may be invisible for some and in its infancy for others. However, the potential to make a change is higher than ever; if we dare to compare and do better - because health literacy matters! 
The illiterate of the $21^{\text {st }}$ century will not be those who cannot read and write, but those who cannot learn, unlearn and relearn.

Alvin Toffler 


\section{Bibliography}

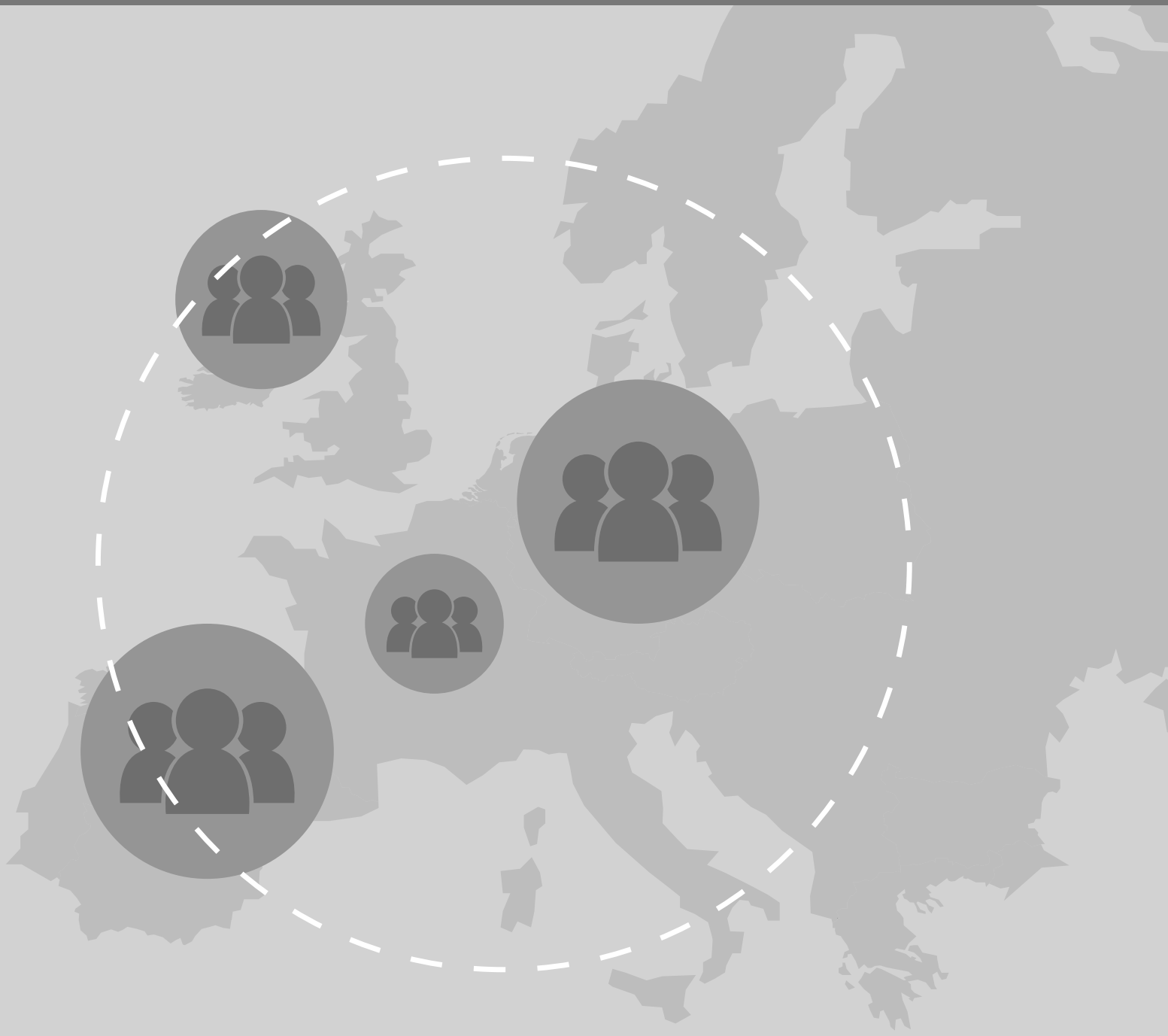




\section{Bibliography}

Aaronson, N., Muller, M., Cohen, P., Essink-Bot, M., Fekkes, M., Sanderman, R., ... Verrips, E. (1998). Translation, Validation, and Norming of the Dutch Language Version of the SF-36 Health Survey in Community and Chronic Disease Populations. Journal of Clinical Epidemiology, 51(11), 1055-1068.

Abelson, J., Forest, P.-G., Eyles, J., Smith, P., Martin, E., \& Gauvin, F.-P. (2003). Deliberations about deliberative methods: issues in the design and evaluation of public participation processes. Social Science \& Medicine, 57(2), 239-251. doi:10.1016/S0277-9536(02)00343-X

Ad Hoc Committee on Health Literacy for the Council on Scientific Affairs, A. M. A. (1999). Health literacy: report of the Council on Scientific Affairs. The Journal Of The American Medical Association, 281(6), 552-557.

Adams, R. J. (2010). Improving health outcomes with better patient understanding and education. Risk Management and Healthcare Policy, 3, 61. doi:10.2147/RMHP.S7500

Adams, R. J., Stocks, N. P., Wilson, D. H., Hill, C. L., Gravier, S., Kickbusch, I., \& Beilby, J. J. (2009). Health literacy--a new concept for general practice? Australian Family Physician, 38(3), 144-147.

Apter, A. J., Paasche-Orlow, M. K., Remillard, J. T., Bennett, I. M., Ben-Joseph, E. P., Batista, R. M., ... Rudd, R. E. (2008). Numeracy and Communication with Patients: They Are Counting on Us. Journal of General Internal Medicine, 23(12), 2117-2124.

Baker, D. W. (2006). The meaning and the measure of health literacy. Journal of general internal medicine, 21(8), 878-83. doi:10.1111/j.1525-1497.2006.00540.x

Baker, D. W., Williams, M., Parker, R., Gazmararian, J. A., \& Nurss, J. (1999). Development of a brief test to measure functional health literacy. Patient Education and Counseling, 38(1), 33-42.

Barber, M. N., Staples, M., Osborne, R. H., Clerehan, R., Elder, C., \& Buchbinder, R. (2009). Up to a quarter of the Australian population may have suboptimal health literacy depending upon the measurement tool: results from a population-based survey. Health promotion international, 24(3), 252-61. doi:10.1093/heapro/dap022

Bartlett, R., \& Collins, S. (2011). Aristotle's Nicomachean ethics. Translated, with an interpretive essay, notes, and glossary. (E-book.). Chicago: Chicago University Press.

Bass, P. F., Wilson, J. F., \& Griffith, C. H. (2003). A shortened instrument for literacy screening. Journal of General Internal Medicine, 18(12), 1036-1038.

Berg, B. L., \& Lune, H. (2011). Qualitative Research Methods for the Social Sciences (8th Edition). Pearson.

Berkman, N. D. (2004). Literacy and Health Outcomes: Evidence Report/Technology Assessment, Number 87. doi:10.1037/e439792005-001

Berkman, N. D., Davis, T. C., \& McCormack, L. (2010). Health literacy: what is it? Journal of Health Communication, 15 Suppl 2(September), 9-19.

Berkman, N. D., Sheridan, S. L., Donahue, K. E., Halpern, D. J., \& Crotty, K. (2011). Low health literacy and health outcomes: an updated systematic review. Annals of Internal Medicine, 155(2), 97-107.

Berry, L. L., Mirabito, A. M., \& Baun, W. B. (2010). What's the hard return on employee wellness programs? Harvard Business Review, 88(3), 104-112, 142.

Bess, K. D., Prilleltensky, I., Perkins, D. D., \& Collins, L. V. (2009). Participatory organizational change in community-based health and human services: from tokenism to political engagement. American journal of community psychology, 43(1-2), 134-48. doi:10.1007/s10464-008-9222-8

Bing. (n.d.). Bing. Retrieved from http://www.bing.com

Boccia, S., Brand, A., Brand, H., \& Ricciardi, G. (2009). The integration of genome-based information for common diseases into health policy and healthcare as a major challenge for Public Health Genomics: the example of the methylenetetrahydrofolate reductase gene in non-cancer diseases. Mutation research, 667(1-2), 27-34. doi:10.1016/j.mrfmmm.2008.10.003 
Boehm, J. (2010). Health Priorities within Europe 2020 - next steps. In Health Priorities within Europe 2020. 2nd CoR Technical Platform on Health: Directorate-General for Health and Consumers Health.

Borg, A. M., \& Sorensen, K. (2012). An Evaluation of National Advisory Boards and Valorization. The European Health Literacy Project 2009-2012. Maastricht: Maastricht University.

Boyle, D., \& Harris, M. (2009). The challenge of co-production. How equal partnerships between professionals and the public are crucial to improving public services. Nesta.

Brach, C., Dreyer, B. P., Schyve, P., Hernandez, L. M., Baur, C., Lemerise, A. J., \& Parker, R. M. (2012). Attributes of a Health Literate Organization. Institute of Medicine.

Brand, H., \& Brand, A. (2007). Public Health Genomics. The integration of genome-based knowledge into public health research, policies and health services. Bundesgesundheitsblatt Gesundheitsforschung Gesundheitsschutz, 50(2), 135-144.

Brugha, R., \& Varvasovszky, Z. (2000). Stakeholder analysis: a review. Health Policy and Planning, 15(3), 239246.

Bryman, A. (2012). Social Research Methods (p. 766). Oxford University Press.

Bubela, T. (2006). Science communication in transition: genomics hype, public engagement, education and commercialization pressures. Clinical Genetics. Wiley-Blackwell.

Buchanan, D. (2000). An ethic for health promotion. Oxford, New York: Oxford University Press.

Buchanan, D. (2006). A new ethic for health promotion. Health Education and Behaviour, 33(290). doi:DOI: 10.1177/1090198105276221

Buchbinder, R., Batterham, R., Ciciriello, S., Newman, S., Horgan, B., Ueffing, E., ... Osborne, R. H. (2011). Health literacy: what is it and why is it important to measure? The Journal of rheumatology, 38(8), 1791-7. doi:10.3899/jrheum.110406

Burke, W., Khoury, M. J., Stewart, A., \& Zimmern, R. L. (2006). The path from genome-based research to population health: development of an international public health genomics network. Genetics in medicine official journal of the American College of Medical Genetics, 8(7), 451-458.

Burmeister, K. (2008). Megatrends. Forum CSR International, 1.

Burton, H., Adams, M., Bunton, R., \& Schröder-Bäck, P. (2009). Developing stakeholder involvement for introducing public health genomics into public policy. Public health genomics, 12(1), 11-19.

Charles, C., \& DeMaio, S. (1993). Lay participation in health care decision making: a conceptual framework. Journal of health politics, policy and law, 18(4), 881-904.

Chew, L. D., Bradley, K. A., \& Boyko, E. J. (2004). Brief questions to identify patients with inadequate health literacy. Family Medicine, 36(8), 588-94.

Chinn, D. (2011). Critical health literacy: a review and critical analysis. Social science \& medicine (1982), 73(1), 60-7. doi:10.1016/j.socscimed.2011.04.004

Clark, B. R. (2011). Using Law to Fight a Silent Epidemic: The Role of Health Literacy in Health Care Access, Quality, and Cost. Annals of Health Law, 20(253).

Coast, J., Smith, R., \& Lorgelly, P. (2008). Should the capability approach be applied in health economics? Health economics, 17(6), 667-70. doi:10.1002/hec.1359

Collins English Dictionary. (2003). Collins English Dictionary - Complete and Unabridged. Harper Collins Publishers.

Commission on Social Determinants of Health. (2008). Closing the gap in a generation: health equity through action on the social determinants of health. Final Report of the Commission on Social Determinants of Health. Geneva.

Corporate Watch. (2006). What is wrong with corporate social responsibility? Oxford.

Coulter, A., \& Ellins, J. (2006). Patient-focussed interventions. A review of evidence. London.

Council of Europe. The European Social Charter (1996). Strasbourg.

Council of Europe. (2000). Recommendation Rec(2005)5 of the Committee of Ministers on the development of structures for citizen and patient participation in the decision-making process affecting health care. Strasbourg. 
Cresswell, J. (2009). Research Design: Qualitative, Quantitative, and Mixed Approaches. Thousand Oaks, CA: SAGE.

CSR Europe. (n.d.-a). CSR Europe. Retrieved from www.csreurope.org

CSR Europe. (n.d.-b). Health And Wellbeing - Enterprise 2020: Our Strategy - CSR Europe. Retrieved March 15, 2013, from http://www.csreurope.org/pages/en/health_literacy_improving_health_knowledge_among_our_employees_and_our_communities.html

CSR Europe. (2010). Enterprise 2020 Market Place. Brussels.

CSR Europe. (2011). Health literacy: Improving health knowledge among our employees. Brussels.

Cutilli, C. C. (2010). Seeking health information: what sources do your patients use? Orthopedic nursing National Association of Orthopedic Nurses, 29(3), 214-219.

Dalli, J. (2011). Commissioner Dalli delivers speech at the European Health Literacy Conference. Brussels.

Daniells, N. (2008). Just Health: Meeting Health Needs Fairly. Cambridge University Press.

Davis, T. C., Gazmararian, J. A., \& Kennen, E. M. (2006). Approaches to improving health literacy: lessons from the field. Journal of health communication, 11(6), 551-4. doi:10.1080/10810730600835517

Davis, T. C., Long, S., Jackson, R., Mayeaux, E., George, R., Murphy, P., \& Crouch, M. (1993). Rapid estimate of adult literacy in medicine: a shortened screening instrument. Family Medicine, 25(6), 391-395.

Davis, T. C., \& Wolf, M. S. (2004). Health literacy: implications for family medicine. Family Medicine, 36(8), 595-598.

De Haes, H. (2006). Dilemmas in patient centeredness and shared decision making: a case for vulnerability. Patient Education and Counseling, 62(3), 291-298.

delle Grazie, J. (2012). European Health Forum Gastein. How can national policy make a difference? The role of health literacy in national health strategies. Bad Hofgastein: European Health Forum Gastein.

Deloitte. (2009). Why change now ? Preparing for the workplace of tomorrow Executive Summary.

DeWalt, D. A., Berkman, N. D., Sheridan, S., Lohr, K. N., \& Pignone, M. P. (2004). Literacy and health outcomes: A systematic review of the literature. Journal of General Internal Medicine, 19(12), 12281239. doi:10.1111/j.1525-1497.2004.40153.x

DG Translation. (2012). DG Translation: Directorate-General for Translation; European Commission. Retrieved April 02, 2013, from http://ec.europa.eu/dgs/translation/index_en.htm

Donev, D., Pavlekovic, G., \& Zaletel, K. L. (2007). Health Promotion and Disease Prevention - A Handbook for Teachers, Researchers, Health Professionals and Decision Makers. Hans Jacobs.

Eichler, K., Wieser, S., \& Brügger, U. (2009). The costs of limited health literacy: a systematic review. International journal of public health, 54(5), 313-24. doi:10.1007/s00038-009-0058-2

Emery, P. G. (2005). Translation, Equivalence and Fidelity: A Pragmatic Approach. Babel Revue internationale de la traduction. International Journal of Translation, 50(2).

Encyclopaedia Britannica. (2011). Encyclopaedia Britannica Mobile edition. Health. Retrieved September 27, 2011, from http://m.eb.com/topic/258178/health

Europakommissionen. (2007). Hvidbog. Sammen om sundhed: en strategi for EU 2008-2013, KOM(2007) 630 endelig. Brussels.

European Commision. (2006). Implementing the partnership for growth and jobs: Making Europe a pole of excellence on corporate social responsibility. Brussels.

European Commission. (2007). Together for Health: A Strategic Approach for the EU 2008-2013. Brussels.

European Commission. (2008). The 2009 Ageing Report: Underlying assumptions and projection methodologies for the EU-27 Member States (2007-2060). Brussels.

European Commission. (2010). Communication from the Commission: Europe 2020. A strategy for smart, sustainable and inclusive growth, COM (2010) 2020. Brussels.

European Commission. (2011). Communication from the commission to the European Parliament, the Council, the European Economic and Social Committee and the Committee of the Regions. A renewed EU strategy 2011-14 for Corporate Social Responsibility. COM(2011) 681 final. Brussels. 
European Health Forum Gastein. (2010). Health in Europe - Ready for the future. Congress Report. Bad Hofgastein.

European Health Forum Gastein. (2012a). The European Health Award 2012. Retrieved from http://www.ehfg.org/award.html

European Health Forum Gastein. (2012b). Crisis and Opportunity Health in an Age of Austerity. Bad Hofgastein.

European Patients' Forum. (2008). Health Literacy. Conference report. European Patients' Forum Spring Conference Brussels, 8-9 April, 2008. Brussels.

Fayers, P., \& Machin, D. (2000). Quality of life. Assessment, analysis and interpretation. Chichester, New York, Weinheim, Brisbane, Singapore and Toronto.: John Wiley \& Sons, LTD.

Fins, J. J. (2012). Health Justice: An Argument From the Capabilities Approach. The Journal of the American Medical Association, 307(19), 2106. doi:10.1001/jama.2012.4817

Fransen, M., Van Schaik, T., Twickler, T. B. M., \& Essink-Bot, M. (2011). Applicability of internationally available health literacy measures in the Netherlands. Journal of Health Communication, 16 Suppl 3(October), 134-49. doi:10.1080/10810730.2011.604383

Fransen, M., Von Wagner, C., \& Essink-Bot, M. (2011). Diabetes self-management in patients with low health literacy: Ordering findings from literature in a health literacy framework. Patient Education and Counseling, 88(1):44-5. doi:10.1016/j.pec.2011.11.015

Freedman, D. a, Bess, K. D., Tucker, H. a, Boyd, D. L., Tuchman, A. M., \& Wallston, K. a. (2009). Public health literacy defined. American journal of preventive medicine, 36(5), 446-51. doi:10.1016/j.amepre.2009.02.001

Friedland, R., \& O'Neill, G. (1998). Understanding Health Literacy: New Estimates of the Costs of Inadequate Health Literacy. Fact Sheet of the National Academy on an Ageing Society. Retrieved from http://www.agingsociety.org/agingsociety/publications/fact/fact_low.html

Frisch, A.-L., Camerini, L., Diviani, N., \& Schulz, P. J. (2012). Defining and measuring health literacy: how can we profit from other literacy domains? Health promotion international, 27(1), 117-26. doi:10.1093/heapro/dar043

Froneberg, B. (2005). Challenges in occupational safety and health from the global market economy and from demographic change-facts, trends, policy response and actual need for preventive occupational health services in Europe. Scandinavian Journal of Work, Environment and Health, Supplement, 23-27.

Froneberg, B. (2007). Occupational health services in adaptation to the challenges of global market competition--new needs, new strategies, new partnerships. Industrial Health, 45(1), 3-7.

Gambles, I. (2009). Making the business case. Proposals that succeed for projects that work. Farnham: Gower.

Gazmararian, J. A., Curran, J. W., Parker, R. M., Bernhardt, J. M., \& DeBuono, B. A. (2005a). Public health literacy in America: an ethical imperative. American journal of preventive medicine, 28(3), 317-22. doi:10.1016/j.amepre.2004.11.004

Gazmararian, J. A., Curran, J. W., Parker, R. M., Bernhardt, J. M., \& DeBuono, B. A. (2005b). Public health literacy in America: an ethical imperative. American journal of preventive medicine, 28(3), 317-22. doi:10.1016/j.amepre.2004.11.004

GESIS. (n.d.). Eurobarometer: Sampling and fieldwork. Retrieved April 02, 2013, from http://www.gesis.org/eurobarometer-data-service/survey-series/standard-special-eb/sampling-andfieldwork/

Gibson, W. (n.d.). The future is here, it is just uneven distributed. Retrieved February 05, 2013, from http://en.wikiquote.org/wiki/William_Gibson

Goldberg, D. S. (2007). Justice, health literacy and social epidemiology. The American journal of bioethics : AJOB, 7(11), 18-20; discussion W1-2. doi:10.1080/15265160701638579

Google. (n.d.-a). Google. Retrieved from http://www.google.com 
Google. (n.d.-b). Google Scolar. Retrieved from http://www.scholar.google.com

Google. (2012). Inside Google Translate. Find out how our translations are created. Retrieved February 03, 2012, from http://translate.google.com/about/index.html

Grayson, D. (2004). Corporate Social Opportunity: Seven steps to make corporate social responsbility work for your business. United Kingdom: Greenleaf.

Griffin, J. M., Partin, M. R., Noorbaloochi, S., Grill, J. P., Saha, S., Snyder, A., ... Van Ryn, M. (2010). Variation in estimates of limited health literacy by assessment instruments and non-response bias. Journal of General Internal Medicine, 25(7), 675-681.

Guttman, N. (2007). Bringing the Mountain to the Public: Dilemmas and Contradictions in the Procedures of Public Deliberation Initiatives That Aim to Get “Ordinary Citizens" to Deliberate Policy Issues. Communication Theory, 17(4), 411-438. doi:10.1111/j.1468-2885.2007.00305.x

Hanson-Divers, E. C. (1997). Developing a medical achievement reading test to evaluate patient literacy skills: a preliminary study. Journal Of Health Care For The Poor And Underserved, 8(1), 56-69.

Hasson, F., Keeney, S., \& McKenna, H. (2000). Research guidelines for the Delphi survey technique. Journal of Advanced Nursing, 32(4), 1008-1015. doi:10.1046/j.1365-2648.2000.t01-1-01567.x

Haun, J., Luther, S., Dodd, V., \& Donaldson, P. (2012). Measurement variation across health literacy assessments: implications for assessment selection in research and practice. Journal of health communication, 17 Suppl 3, 141-59. doi:10.1080/10810730.2012.712615

Health Literacy Europe. (n.d.). www.health-literacy.eu. Retrieved from www.health-literacy.eu

Health Literacy Innovations. (n.d.). The Health Literacy \& Plain Language Resource Guide.

Hennink, M., Hutter, I., \& Bailey, A. (2011). Qualitative research methods. London: Sage Publications Ltd.

HLS-EU Consortium. (2008). The European Health Literacy Project Grant Agreement 2007-113.

HLS-EU Consortium. (2012a). Comparative report on health literacy in eight EU member states. The European Health Literacy Project 2009-2012. Vienna.

HLS-EU Consortium. (2012b). Final report Executive summary ( D17) The European Health Literacy Project. Maastricht: Maastricht University.

Holmquist, M. (2009). Corporate social responsibility as corporate social control: The case of work-site health promotion. Emeral Management Reviews, 25(1), 68-72.

Hopper, K. (2007). Rethinking social recovery in schizophrenia: what a capabilities approach might offer. Social science \& medicine (1982), 65(5), 868-79. doi:10.1016/j.socscimed.2007.04.012

Horev, T., \& Babad, Y. M. (2005). Healthcare reform implementation: stakeholders and their roles-the Israeli experience. Health Policy, 71(1), 1-21.

Ibrahim, S., Reid, F., Shaw, A., Rowlands, G., Gomez, G., Chesnokov, M., \& Ussher, M. (2008). Validation of a health literacy screening tool (REALM) in a UK population with coronary heart disease. Journal of public health (Oxford, England), 30(4), 449-55. doi:10.1093/pubmed/fdn059

Ishikawa, H., \& Kiuchi, T. (2010). Health literacy and health communication. Family Practice Management, $4(6), 18$.

Ishikawa, H., Nomura, K., Sato, M., \& Yano, E. (2008). Developing a measure of communicative and critical health literacy: a pilot study of Japanese office workers. Health Promotion International, 23(3), 269274.

Ishikawa, H., \& Yano, E. (2008). Patient health literacy and participation in the health-care process. Health expectations : an international journal of public participation in health care and health policy, 11(2), 113-22. doi:10.1111/j.1369-7625.2008.00497.x

Jarvis, J. (2009). What Would Google Do? New York: Harvard Business.

Johnson, J., Case, D. O., Andrews, J. E., \& Allard, S. L. (2005). Genomics - The Perfect Information-Seeking Research Problem. Journal of Health Communication, 10(4), 323-329. doi:10.1080/10810730590950048

Johnson, R. B., \& Christensen, L. B. (2012). Educational Research: Quantitative, Qualitative, and Mixed Approaches. Thousand Oaks, CA: SAGE Publications, Inc. 
Joint Venture of Business Action on Health Literacy, \& CSR Europe. (2013). Blueprint for Business Action on Health Literacy. Creating value for employees, businesses and indrectly for the wider communities. Brussels.

Jordan, J. E., Buchbinder, R., Briggs, A. M., Elsworth, G. R., Busija, L., Batterham, R., \& Osborne, R. H. (2013). The health literacy management scale (HeLMS): a measure of an individual's capacity to seek, understand and use health information within the healthcare setting. Patient education and counseling, 91(2), 228-35. doi:10.1016/j.pec.2013.01.013

Jordan, J. E., Osborne, R. H., \& Buchbinder, R. (2011). Critical appraisal of health literacy indices revealed variable underlying constructs, narrow content and psychometric weaknesses. Journal of Clinical Epidemiology, 64(4), 366-379.

Kamper-Jørgensen, F., Almind, G., \& Jensen, B. (2010). Forebyggende sundhedsarbejde (5th ed.). Munksgaard Danmark.

Keane, J. (2009). The life and death of democracy. London: Simon and Schuster.

Khoury, M. J. (2010). Dealing with the evidence dilemma in genomics and personalized medicine. Clinical Pharmacology \& Therapeutics, 87(6), 635-638.

Khoury, M. J., Gwinn, M., Yoon, P. W., Dowling, N., Moore, C. A., \& Bradley, L. (2007). The continuum of translation research in genomic medicine: how can we accelerate the appropriate integration of human genome discoveries into health care and disease prevention? Genetics in medicine official journal of the American College of Medical Genetics, 9(10), 665-674.

Kickbusch, I. (2002). Health literacy: a search for new categories. Health promotion international, 17(1), 1-2.

Kickbusch, I. (2007). Responding to the health society. Health promotion international, 22(2), 89-91. doi:10.1093/heapro/dam014

Kickbusch, I. (2009). Health literacy: engaging in a political debate. International journal of public health, 54(3), 131-2. doi:10.1007/s00038-009-7073-1

Kickbusch, I. (2011). Health Promotion interHL. Health Promotion International, 3(16), 289-297.

Kickbusch, I. (2012). Learning for Wellbeing. A policy priority for children and youth in europe. A process for change, with the collaboration of Jean Gordon \& Linda O'Toole, drafted on behalf of the Learning for Well-being Consortium of Foundations in Europe.

Kickbusch, I., \& Gleicher, D. (2012). Governance for health in the 21st century. Geneva.

Kickbusch, I., \& Maag, D. (2008). Health Literacy. In K. Heggenhougen \& S. Quah (Eds.), International Encyclopedia of Public Health (Vol. 3, pp. 204-211). San Diego: Academic Press.

Kickbusch, I., Pelikan, J., Apfel, F., \& Agis, T. (2013). Health literacy: the solid facts (1st editio.). Copenhagen: World Health Organisation Regional Office for Europe.

Kickbusch, I., Wait, S., \& Maag, D. (2005). Navigating health. The role of health literacy. Alliance for Health and the Future, International Longevity Centre-UK.

Kipling, R. (1902). The elephant's child: I keep six honest men... The Elephant's Child. www.kipling.org.

Kirsch, I. (2001). The International Adult Literacy Survey (IALS): Understanding What Was Measured. Researcher Report. RR-01-25. Princeton, NJ.

Kolind, L., \& Bøtter, J. (2012). Unboss. Jyllandspostens Forlag.

Kondilis, B. K., Kiriaze, I. J., Athanasoulia, A. P., \& Falagas, M. E. (2008). Mapping health literacy research in the European Union: a bibliometric analysis. (D. Husereau, Ed.)PloS one, 3(6), e2519. doi:10.1371/journal.pone.0002519

Kondilis, B. K., Soteriades, E. S., \& Falagas, M. E. (2006). Health literacy research in Europe: a snapshot. European journal of public health, 16(1), 113. doi:10.1093/eurpub/cki204

Kutner, M., Greenberg, E., Jin, Y., \& Paulsen, C. (2006a). The health literacy of America's adults: results from the 2003 National Assessment of Adult Literacy (NCES 2006-483). Washington (DC): US Department of Education. National Center for Education Statistics.

Kutner, M., Greenberg, E., Jin, Y., \& Paulsen, C. (2006b). The health literacy of America's adults: results from the 2003 National Assessment of Adult Literacy. Education, 6, 1-59. 
Kwan, B., Frankish, J., Rootman, I., Zumbo, B., Kelly, K., Begoray, D. L., ... Hayes, M. (2006). The Development and Validation of Measures of "Health Literacy" in Different Populations.

Lang, T., \& Rayner, G. (2010). Corporate responsibility in public health. BMJ (Clinical research ed.), 341, c3758.

Lapsley, P. (2013). Lessons from patients' journeys. BMJ, 346(apr03 2), f1988-f1988. doi:10.1136/bmj.f1988

Larson, M. (1998). Meaning based translation, a guide to cross-language equivalence. (2nd ed.). Lanham, New York and London.: University Press of America.

Lee, S.-Y. D., Arozullah, A. M., \& Cho, Y. I. (2004). Health literacy, social support, and health: a research agenda. Social science \& medicine (1982), 58(7), 1309-21. doi:10.1016/S0277-9536(03)00329-0

Lee, T. W., Kang, S. J., Lee, H. J., \& Hyun, S. I. (2009). Testing health literacy skills in older Korean adults. Patient Education and Counseling, 75(3), 302-307.

Leger, L. S. T. (2001). Schools, health literacy and public health: possibilities and challenges. Health Promotion International, 16(2).

Lenfant, C. (2003). Clinical Research to Clinical Practice - Lost in Translation? New England Journal of Medicine, 349(9), 868-874. doi:10.1056/NEJMsa035507

Leplège, A., Ecosse, E., Verdier, A., \& Perneger, T. V. (1998). The French SF-36 Health Survey. Journal of Clinical Epidemiology, 51(11), 1013-1023. doi:10.1016/S0895-4356(98)00093-6

Leto di Priolo, S., Fehervary, A., Riggins, P., \& Redmond, K. (2012). Assessing stakeholder opinion on relations between cancer patient groups and pharmaceutical companies in Europe. The patient, 5(2), 127-39. doi:10.2165/11589210-000000000-00000

Levin-Zamir, D., \& Peterburg, Y. (2001). Health literacy in health systems: perspectives on patient selfmanagement in Israel. Health promotion international, 16(1), 87-94.

Lewis, L. (2012). The capabilities approach, adult community learning and mental health. Community Development Journal, 47(4), 522-537. doi:10.1093/cdj/bss027

Ley, S. (2011). Patient and citizen participation in health care systems.

Lincoln, Y., \& Guba, E. (1985). Naturalistic Inquiry. New Bury Park: Sage Publications.

Lindström, B., \& Eriksson, M. (2011). From health education to healthy learning: implementing salutogenesis in educational science. Scandinavian Journal of Public Health, 39(6 Suppl), 85-92.

Lloyd, L. L. J., Ammary, N. J., Epstein, L. G., Johnson, R., \& Rhee, K. (2006). A transdisciplinary approach to improve health literacy and reduce disparities. Health Promotion Practice, 7(3), 331-335.

Longo, D. R. (2005). Understanding health information, communication, and information seeking of patients and consumers: a comprehensive and integrated model. Health expectations an international journal of public participation in health care and health policy. Wiley Online Library.

Lynch, W. D. (2002). What is a healthy employee worth? Absolute advantage, 16-19.

Mackie, J. (1990). Ethics. Inventing right and wrong. London: Penquin Group.

Madsen, M., Højgaard, B., \& Albæk J. (2009). Health literacy - begrebet, konsekvenser og mulige interventioner. København: Sundhedsstyrelsen.

Magasi, S., Durkin, E., Wolf, M. S., \& Deutsch, A. (2009). Rehabilitation consumers' use and understanding of quality information: a health literacy perspective. Archives of Physical Medicine and Rehabilitation, 90(2), 206-212.

Mancuso, J. M. (2008). Health literacy: a concept/dimensional analysis. Nursing \& health sciences, 10(3), 248-55. doi:10.1111/j.1442-2018.2008.00394.x

Mancuso, J. M. (2009). Assessment and measurement of health literacy: an integrative review of the literature. Nursing \& health sciences, 11(1), 77-89. doi:10.1111/j.1442-2018.2008.00408.x

Manganello, J. (2008). Health literacy and adolescents: a framework and agenda for future research. Health education research, 23(5), 840-7. doi:10.1093/her/cym069

Marmot, M. (2004). Social causes of social inequalities in health. In F. and S. A. Anand, S., Peter (Ed.), Public health, ethics and equity. Oxford: Oxford University Press. 
Marmot, M. (2006). Status syndrome: A challenge to medicine. Journal of the American Medical Association, 296(11).

Marshall, M. (1996). Sampling for qualitative research. Family Practice, 13(6), 522-525.

Mårtensson, L., \& Hensing, G. (2012). Health literacy - a heterogeneous phenomenon: a literature review. Scandinavian Journal of Caring Sciences, 26(1), 151-60. doi:10.1111/j.1471-6712.2011.00900.x

McCormack, L., Valerio, M., Haun, J., \& Sorensen, K. (2012). Panel D: Improving coherence between health literacy frameworks and measures. Annual Health Literacy Research Conference, Bethesda, 2012. Bethesda, Washington.

McCray, A. T. (2005). Promoting health literacy. [Review] [204 refs]. Journal of the American Medical Informatics Association, 12(2), 152-163.

McQueen, D., Kickbusch, I., Potvin, L., Pelikan, J., Balbo, L., \& Abel, T. (2007). Health and Modernity. The Role of Theory in Health Promotion. Springer.

Merriam-Webster. (2011). Merriam-Webster Online. Retrieved April 02, 2013, from http://www.merriamwebster.com/

Merriam-Webster Dictionary. (n.d.). Mover and shaker - Definition and More from the Free MerriamWebster Dictionary. Retrieved March 02, 2013, from http://www.merriam-webster.com/dictionary/mover and shaker

Michie, S., Van Stralen, M. M., \& West, R. (2011). The behaviour change wheel: A new method for characterising and designing behaviour change interventions. Implementation science IS, 6(1), 42.

Miles, M. B., \& Huberman, A. M. (1994). Qualitative Data Analysis: An Expanded Sourcebook (2nd ed.). SAGE Publications, Inc.

Mitchell, R. K., Agle, B. R., \& Wood, D. J. (1997). Toward a Theory of Stakeholder Identification and Salience: Defining the Principle of Who and What Really Counts. Academy of Management Review, 22(4), 853886. doi:10.2307/259247

Montero, M. J., Araque, R. A., \& Rey, J. M. (2009). Occupational health and safety in the framework of corporate social responsibility. Safety Science, 47(10), 1440-1445. doi:10.1016/j.ssci.2009.03.002

Myant, K., \& Urquhart, G. (2007). Social science methods series Guide 1: Deliberative Methods Social Science Methods Series : Deliberative Methods.

Nielsen-Bohlman, L. T., Panzer, A. M., \& Kindig, D. A. (2004). Health Literacy: A Prescription to End Confusion. San Fransisco: The National Academies Press.

Nussbaum, M. (2011). Creating Capabilities. The human development approach. Cambridge, Massachusetss, and London, England.: The Belknap Press of Harvard University Press.

Nussbaum, M., \& Sen, A. (1993). The quality of life. Oxford, New York: Oxford University Press.

Nutbeam, D. (1998). Health Promotion Glossary. Health Promotion International, 13(4).

Nutbeam, D. (2000a). Health literacy as a public health goal: a challenge for contemporary health education and communication strategies into the 21st century. Health Promotion International, 15(3), 259-267. doi:10.1093/heapro/15.3.259

Nutbeam, D. (2000b). Advancing health literacy: a global challenge for the 21st century. Health Promotion International, 15(3), 183-184. doi:10.1093/heapro/15.3.183

Nutbeam, D. (2006). Health literacy as a public health goal : a challenge for contemporary health education and communication strategies into the 21st century contemporary health, 15(3), 259-268.

Nutbeam, D. (2008). The evolving concept of health literacy. Social science \& medicine (1982), 67(12), 20728. doi:10.1016/j.socscimed.2008.09.050

Nutbeam, D. (2012). Personal communication.

O’Flaherty, J., Liddy, M., Tansey, L., \& Roche, C. (2011). Educating engaged citizens: four projects from Ireland. Education + Training, 53(4), 267-283. doi:10.1108/00400911111138442

OECD. (2001). Engaging Citizens in Policy-making: Information, Consultation and Public Participation. OECD Public Management Policy Brief. 
Osborn, C. Y., Weiss, B. D., Davis, T. C., Skripkauskas, S., Rodrigue, C., Bass, P. F., \& Wolf, M. S. (2007). Measuring adult literacy in health care: performance of the newest vital sign. American Journal of Health Behavior, 31 Suppl 1(Suppl 3), S36-S46.

Osborne, R. H., Batterham, R. W., Elsworth, G. R., Hawkins, M., \& Buchbinder, R. (2013). The grounded psychometric development and initial validation of the Health Literacy Questionnaire (HLQ). BMC public health, 13(1), 658. doi:10.1186/1471-2458-13-658

Ouye, J. A. (2011). Five Trends that Are Dramatically Changing Work and the Workplace. New Ways of Working, LCC and Knoll, Inc.

Oxley, H. (2009). OECD Health Working Papers No. 42 Policies for healthy aging: an overview.

Paasche-Orlow, M. K. (2009). Bridgeing the international divide for health literacy research. Patient Education and Counseling, 75, 293-294.

Paasche-Orlow, M. K., Parker, R. M., Gazmararian, J. A., Nielsen-Bohlman, L. T., \& Rudd, R. R. (2005a). The prevalence of limited health literacy. Journal of general internal medicine, 20(2), 175-84. doi:10.1111/j.1525-1497.2005.40245.x

Paasche-Orlow, M. K., Parker, R. M., Gazmararian, J. A., Nielsen-Bohlman, L. T., \& Rudd, R. R. (2005b). The prevalence of limited health literacy. Journal of General Internal Medicine, 20(2), 175-184.

Paasche-Orlow, M. K., \& Wolf, M. S. (2007). The causal pathways linking health literacy to health outcomes. American Journal of Health Behavior, 31 Suppl 1(Suppl 1), S19-S26.

Paasche-orlow, M. K., \& Wolf, M. S. (2007). Literacy to Health Outcomes. Social Science, 31(Suppl 1), 19-26.

Parker, R. M. (2000). Health literacy: a challenge for American patients and their health care providers. Health Promotion International, 15(4), 277-283. doi:10.1093/heapro/15.4.277

Parker, R. M., Baker, D. W., Williams, M., \& Nurss, J. (1995). The test of functional health literacy in adults. Journal of General Internal Medicine, 10(10), 537-541.

Parker, R. M., \& Gazmararian, J. A. (2003). Health literacy: essential for health communication. Journal of health communication, 8 Suppl 1(781062704), 116-8. doi:10.1080/713851963

Parker, R. M., \& Ratzan, S. C. (2010). Health literacy: a second decade of distinction for Americans. Journal of health communication, 15 Suppl 2, 20-33. doi:10.1080/10810730.2010.501094

Pavlekovic, G. (2008). Health literacy. Programmes for Training on Research in Public Health for South Eastern Europe. Vol. 4: Health Promotion and Disease Prevention: A Handbook for Teachers, Researchers, Health Professionals and Decision Makers (pp. 463-466).

Peerson, A., \& Saunders, M. (2009). Health literacy revisited: what do we mean and why does it matter? Health Promotion International, 24(3), 285-296.

Peter Fawcett. (1997). Translation and language : linguistic theories explained. Manchester: St. Jerome.

Pieterse, J. N. (2001). Participatory democratization reconceived, 33(April 2000), 407-422.

Pleasant, A. (2008). International Health Association Conference. In Proposed definition.

Pleasant, A. (2011). Health literacy: An opportunity to improve individual, community, and global health. New Directions for Adult and Continuing Education, 2011(130), 43-53. doi:10.1002/ace.409

Pleasant, A. (2012). Health Literacy Around the World: Part 1 Health Literacy Efforts Outside Of the United States.

Pleasant, A., \& Kuruvilla, S. (2008). A tale of two health literacies: public health and clinical approaches to health literacy. Health Promotion International, 23(2), 152-159.

Pleasant, A., \& McKinney, J. (2011). Coming to consensus on health literacy measurement: an online discussion and consensus-gauging process. Nursing outlook, 59(2), 95-106.e1. doi:10.1016/j.outlook.2010.12.006

Pleasant, A., McKinney, J., \& Rikard, R. V. (2011). Health literacy measurement: a proposed research agenda. Journal of health communication, 16 Suppl 3, 11-21. doi:10.1080/10810730.2011.604392

Porr, C., Drummond, J., \& Richter, S. (2006). Health Literacy as an Empowerment Tool for Low-income Mothers. Family Community Health, 29(4), 328-335. 
Porter, M. ., \& Kramer, M. . (2006). Strategy and society. The link between competitive advantage and corporate social responsibility. Harvard Business Review,, 1-16.

Portney, P. R. (2008). The (Not So) New Corporate Social Responsibility: An Empirical Perspective. Review of Environmental Economics and Policy, 2(2), 261-275. doi:10.1093/reep/ren003

Powers, M., \& Faden, R. (2006). Social justice. The moral foundations of public health and health policy. Oxford, New York: Oxford University Press.

Protheroe, J., Wallace, L. S., Rowlands, G., \& DeVoe, J. E. (2009). Health literacy: setting an international collaborative research agenda. BMC family practice, 10(1), 51. doi:10.1186/1471-2296-10-51

Puntoni, S. (2012). Health literacy in Wales. A scoping document for Wales. Public Health Wales; Welsh Assembly Government.

Pym, A. (2010). Exploring Translational Theories. London, New York: Routhledge, Taylor \& Francis e-Library.

Quittner, A. L., Sweeny, S., Watrous, M., Munzenberger, P., Bearss, K., Gibson Nitza, A., ... Henry, B. (2000). Translation and linguistic validation of a disease-specific quality of life measure for cystic fibrosis. Journal of Pediatric Psychology, 25(6), 403-414.

Ratzan, S. C. (2001). Health literacy: communication for the public good. Health promotion international, 16(2), 207-14.

Robbins, A. (2003). Public health literacy for lawyers: teaching population-based legal analysis. Environmental Health Perspectives, 111(4), 744-745.

Robeyns, I. (2006). The Capability Approach in Practice*. Journal of Political Philosophy, 14(3), 351-376. doi:10.1111/j.1467-9760.2006.00263.x

Rogers, E. M. (2003). Diffusion of Innovations, 5th Edition (4th ed.). The Free Press.

Roman, S. H., \& Harris, M. I. (1997). Management of diabetes mellitus from a public health perspective. Endocrinology and metabolism clinics of North America, 26(3), 443-74.

Rootman, I., \& Gordon-El-Bihbety, D. (2008). A Vision for a Health Literate Canada Report of the Expert Panel on Health Literacy. Ottawa.

Rosenkotter, N., Vondeling, H., Blancquaert, I., Mekel, O. C., Kristensen, F. B., \& Brand, A. (2011). The contribution of health technology assessment, health needs assessment, and health impact assessment to the assessment and translation of technologies in the field of public health genomics. Public Health Genomics.

Ross Adkins, N., \& Corus, C. (2009). Health Literacy for Improved Health Outcomes: Effective Capital in the Marketplace. Journal of Consumer Affairs, 43(2), 199-222. doi:10.1111/j.1745-6606.2009.01137.x

Rowe, G. (2005). A Typology of Public Engagement Mechanisms. Science, Technology \& Human Values, 30(2), 251-290. doi:10.1177/0162243904271724

Rowlands, G. (2012). Health literacy and public health: a framework for developing skills and empowering citizens. Perspectives in Public Health, 132(1), 23-24. doi:10.1177/1757913911430916

Rubinelli, S., Schulz, P. J., \& Nakamoto, K. (2009). Health literacy beyond knowledge and behaviour: letting the patient be a patient. International journal of public health, 54(5), 307-11. doi:10.1007/s00038009-0052-8

Rudd, R. R., Kirsch, I., \& Yamamoto, K. (2004). Literacy and health in America. Princeton, NJ: Educational Testing Service.

Rudd, R. R., Moeykens, B. ., \& Colton, T. (1999). Health and Literacy: A review of the medical and public health literature, chapter 5. In J. P. Comings, C. Smith, \& B. Garner (Eds.), Annual Review of Adult Learning and Literacy. San Francisco CA: Jossey-Bass.

Ruger, J. P. (2010). Health capability: conceptualization and operationalization. American journal of public health, 100(1), 41-9. doi:10.2105/AJPH.2008.143651

Ryan, G. W., \& Bernard, H. R. (2003). Field Methods. Field Methods, 15(1), 85-109. doi:10.1177/$1525822 \times 02239569$

Saha, S. (2006). Improving literacy as a means to reducing health disparities. Journal of general internal medicine, 21(8), 893-5. doi:10.1111/j.1525-1497.2006.00546.x 
Saith, R. (2011). A Public Health Perspective on the Capability Approach. Journal of Human Development and Capabilities, 12(4), 587-589.

Schmeer, K. (n.d.). Stakeholder analysis guidelines. Section 2.

Schriefer, A. E. (2005). Workplace strategy: What it is and why you should care. Journal of Corporate Real Estate, 7(3), 222-233. doi:10.1108/14630010510631081

Schröder-Bäck, P., Clemens, T., Michelsen, K., Schulte, T., Bäumen, D., Sørensen, K., ... Brand, H. (2012). Public Health Ethical Perspectives on European Commission's White Paper "Together for Health." Central European Journal of Public Health, 20(2), 95-100.

Schuh, B. (2011). Promoting health literacy: An ethical analysis. Maastricht University.

Schyve, P. M. (2007). Language differences as a barrier to quality and safety in health care: the Joint Commission perspective. Journal of general internal medicine, 22 Suppl 2, 360-1. doi:10.1007/s11606-007-0365-3

Scott, J. (2009). Managing the new frontiers. An introduction to the fundamentals. Retrieved from Management Education Services.

Sentell, T. L., \& Halpin, H. A. (2006). Importance of adult literacy in understanding health disparities. Journal of general internal medicine, 21(8), 862-6. doi:10.1111/j.1525-1497.2006.00538.x

Services, H. (2011). Health Literacy Interventions and Outcomes: An Updated Systematic Review. Search, 155(2), 97-107. doi:10.1059/0003-4819-155-2-201107190-00005

Sheedy, A., Mackinnon, P., Pitre, S., \& Watling, J. (2008). Handbook on Citizen Engagement: Beyond Consultation.

Simonds, S. (1974). Health education as sociol policy. Health Education Monograph, 2, 1-25.

Sorensen, K. (2011). Health literacy as outcome of corporate social responsibility practice. Maastricht: Maastricht University and CSR Europe.

Sorensen, K. (2012). G.3. Workshop: Health literacy in Europe; the European Public Health Conference, Malta, 2012. In Health literacy on the European health agenda.

Sorensen, K., \& Brand, H. (2011a). Health literacy--a strategic asset for corporate social responsibility in Europe. Journal of health communication, 16 Suppl 3, 322-7. doi:10.1080/10810730.2011.606072

Sorensen, K., \& Brand, H. (2011b). Health literacy: the essential catalyst for the responsible and effective translation of genome-based information for the benefit of population health. Public Health Genomics, 14(4-5).

Sorensen, K., Felder, Z., \& Media\&More. (2012). HLS-EU the Movie. HLS-EU Consortium. Retrieved from http://www.youtube.com/watch?v=fzMA9TIPJUk

Sorensen, K., Felder, Z., \& Media\&More. (2013). Gesundheitskompetenz- HLS-EU Der Film. HLS-EU Consortium. Retrieved from http://www.youtube.com/watch?v=xlxGil-bnmg

Sorensen, K., Nørgaard, O., \& Maindal, H. (2013). Behov for mere forskning i patienters sundhedskompetence. Ugeskrift for læger, in press.

Sorensen, K., Tsflidis, B., Heel, V. van, \& Brand, H. (2011). CAPRHI Day; Maastricht University. In Scope study of health literacy activities for employees as part of corporate social responsibility. Maastricht, the Netherlands.

Sorensen, K., Van den Broucke, S., Fullam, J., Doyle, G., Pelikan, J., Slonska, Z., \& Brand, H. (2012). Health literacy and public health: a systematic review and integration of definitions and models. BMC public health, 12(1), 80. doi:10.1186/1471-2458-12-80

Sorensen, K., Van den Broucke, S., Pelikan, J., Fullam, J., Doyle, G., Slonska, Z., ... Brand, H. (2013). Measuring health literacy in populations: illuminating the design and development process of HLS-EU-Q. BMC public health - in review.

Speros, C. (2005). Health literacy: concept analysis. Journal of advanced nursing, 50(6), 633-40. doi:10.1111/j.1365-2648.2005.03448.x

Spycher, S. (2006). Ökonomische Aspekte der Gesundheitskompetenzen. Konzeptpapier im Auftrag des Bundesamtes für Gesundheit. Retrieved from www.bag.admin.ch 
Steckelberg, A., Hülfenhaus, C., Kasper, J., Rost, J., \& Mühlhauser, I. (2009). How to measure critical health competences: development and validation of the Critical Health Competence Test (CHC Test). Advances in health sciences education : theory and practice, 14(1), 11-22. doi:10.1007/s10459-0079083-1

Strauss, A., \& Corbin, J. M. (1990). Basics of Qualitative Research: Techniques and Procedures for Developing Grounded Theory. Sage Publications.

Streiner, D., \& Norman, G. (2008). Health measurement scales. A practical guide to their development and use (4th ed.). New York: Oxford University Press.

Syurina, E., Brankovic, I., Probst-Hensch, N., \& Brand, A. (2011). Genome-based health literacy: a new challenge for public health genomics. Public health genomics, 14(4-5), 201-210.

Taler, R. H., \& Sunstein, C. R. (2008). Nudge: Improving Decisions about Health, Wealth, and Happiness. Yale University Press.

Tambini, D. (1999). New Media and Democracy: The Civic Networking Movement. New Media \& Society, 1(3), 305-329. doi:10.1177/14614449922225609

Tappe, M. K., \& Galer-Unti, R. A. (2001). Health educators' role in promoting health literacy and advocacy for the 21st century. The Journal of school health, 71(10), 477-482.

Taylor, P. (2010). Health literacy and the Millennium Development Goals: United Nations Economic and Social Council (ECOSOC) regional meeting background paper (abstracted). Journal of Health Communication, 15 Supp/ 2(September), 211-23. doi:10.1080/10810730.2010.499996

The New Oxford American Dictionary. (2008). The New Oxford American Dictionary. Hamburg: 2nd edition 2005. Oxford University Press, Inc. as eBook 2008 by Kreutzfeld Electronic Publishing GmbH.

The Nordic Health Literacy Network. (n.d.). The Nordic Health Literacy Network. Retrieved from http://www.norhl.net

The Phrase Finder. (n.d.). "Movers and Shakers." Retrieved February 28, 2013, from http://www.phrases.org.uk/meanings/movers-and-shakers.html

Toffler, A. (1970). Future shock. Bantam Books.

Tones, K. (2002a). Health literacy: new wine in old bottles? Health Education Research, 17(3), 287-290. doi:10.1093/her/17.3.287

Tones, K. (2002b). Health literacy: new wine in old bottles? Health education research, 17(3), 287-90.

Twickler, T. B. M., Hoogstraaten, E., Reuwer, A. Q., Singels, L., Stronks, K., \& Essink-Bot, M.-L. (2009). Low literacy and limited health literacy require health care measures. Nederlands Tijdschrift Voor Geneeskunde, 153, A250.

U.S. Department of Health and Human Services. (2010). Action Plan to Improve Health Literacy. Washington DC.

Ulin, P. R., Robinson, E. T., \& Tolley, E. E. (2004). Qualitative Methods in Public Health: A Field Guide for Applied Research: Jossey-Bass.

Ulrych, M. (2002). An evidence-based approach to translation in Translation Studies. Perspectives on an Emerging Discipline. (A. Riccardi, Ed.). Cambridge: University Press.

Undervisningsministeriet. (2005). Det nationale kompetenceregnskab. Hovedrapport. København.

UNESCO. (2005). Literacy for all. Education for All Global Monitoring Report 2006.

United Nations Department of Public Information. (n.d.). Universal declaration of human rights. Dignity and justice for all of us. 60th Anniversary. Special edition 1948-2008. (E-Book.). United Nations.

Van der Heide, I., Rademakers, J., Schipper, M., Droomers, M., Sorensen, K., \& Uiters, E. (2013). Health literacy of Dutch adults: a cross sectional survey. BMC public health, 13(1), 179. doi:10.1186/14712458-13-179

Varvasovszky, Z., \& Brugha, R. (2000). How to do ( or not to do ) . . A stakeholder analysis. Health Policy and Planning, 15(3), 338-345. doi:10.1093/heapol/15.3.338

Visser, W., Matten, D., Pohl, M., \& Tolhurst, N. (2007). The A to Z of Corporate Social Responsibility. Link (Vol. 1, p. 505). Wiley. 
Volandes, A. E., \& Paasche-Orlow, M. K. (2007). Health literacy, health inequality and a just healthcare system. The American journal of bioethics : AJOB, 7(11), 5-10. doi:10.1080/15265160701638520

Von Wagner, C., Knight, K., Steptoe, A., \& Wardle, J. (2007). Functional health literacy and health-promoting behaviour in a national sample of British adults. Journal of epidemiology and community health, 61(12), 1086-90. doi:10.1136/jech.2006.053967

Wade, C. H., McBride, C. M., Kardia, S. L. R., \& Brody, L. C. (2010). Considerations for designing a prototype genetic test for use in translational research. Public health genomics, 13(3), 155-165.

Wang, J., \& Schmid, M. (2007). Regional differences in health literacy in Switzerland. Zürich.

Wang, J., Schmid, M. R., \& Thombs, B. D. (2012). The Swiss Health Literacy Survey: development and psychometric properties of a multidimensional instrument to assess competencies for health. Health expectations: an international journal of public participation in health care and health policy. doi:10.1111/j.1369-7625.2012.00766.x

Wang, R. (2000). Critical health literacy: a case study from China in schistosomiasis control. Health Promotion International, 15(3), 269-274. doi:10.1093/heapro/15.3.269

Weiss, B. D., Mays, M. Z., Martz, W., Castro, K. M., DeWalt, D. A., Pignone, M. P., ... Hale, F. A. (2005). Quick Assessment of Literacy in Primary Care: The Newest Vital Sign. Annals Of Family Medicine, 3(6), 514 522.

Welsh Assembly Government. (2011). Fairer Health Outcomes For All. Cardiff.

Whitehead, M. (1991). The concepts and principles of equity and health. Health Promotion International, 6(3), 217-228. doi:10.1093/heapro/6.3.217

WHO Regional Office for Europe. (1986). Ottawa Charter for health promotion.

Wills, J. (2009). Health literacy: new packaging for health education or radical movement? International journal of public health.

World Economic Forum. (2012). The Workplace Wellness Alliance. Investing in a sustainable workforce; in collaboration with the Boston Consulting Group. Cologny/Geneva.

World Economic Forum prepared in collaboration with Bain \& Company. (2013). Charter for Healthy Living. A report from the World Economic Forum's Healthy Living Initiative. Geneva.

World Health Organisation. (2008). Workers Health is a Corporate Social Responsibility. Environmental Health Update. Sustainable Development and Healthy Environments, 3(5).

World Health Organisation. (2009). Nairobi Call to Action.

World Health Organisation. Division of mental health and prevention of substance abuse. (1997). WHOQOL. Quality of life. WHO/MSA/MNH/PSF/97.4. Geneva.

World Health Organisation's European Office. (2009). Statements from Global Conferences. Health Promotion. (pp. 1-42). OMS.

World Health Organisation's European Office. (2011). The new European policy for health - Health 2020: Vision, values, main directions and approaches. EUR/RC61/9 + EUR/RC61/Conf.Doc./2.

World Health Organisation's European Office. (2012). Health 2020: a European policy framework supporting action across government and society for health and well-being. Copenhagen.

Yahoo! (n.d.). Yahoo! Retrieved from http://yahoo.com

Yost, K. J., Webster, K., Baker, D. W., Choi, S. W., Bode, R. K., \& Hahn, E. A. (2009). Bilingual health literacy assessment using the Talking Touchscreen/la Pantalla Parlanchina: Development and pilot testing. Patient education and counseling, 75(3), 295-301. doi:10.1016/j.pec.2009.02.020

Zanchetta, M. S., \& Poureslami, I. M. (2006). Health literacy within the reality of immigrants' culture and language. Canadian Journal Of Public Health Revue Canadienne De Sante Publique, 97 Suppl 2(2), S26-S30.

Zarcadoolas, C., Pleasant, A., \& Greer, D. S. (2003). Elaborating a definition of health literacy: a commentary. Journal of health communication, 8 Suppl 1(781062704), 119-20. doi:10.1080/713851982

Zarcadoolas, C., Pleasant, A., \& Greer, D. S. (2005). Understanding health literacy: an expanded model. Health promotion international, 20(2), 195-203. doi:10.1093/heapro/dah609 
Zarcadoolas, C., Pleasant, A., \& Greer, D. S. (2012). Advancing Health Literacy: A Framework for Understanding and Action (Google eBook) (p. 396). John Wiley \& Sons. 
Freedom means you're free to do

just whatever pleases you;

- if, of course that is to say,

what you please is what you may.

Piet Hein 
Figures, tables and abbreviations

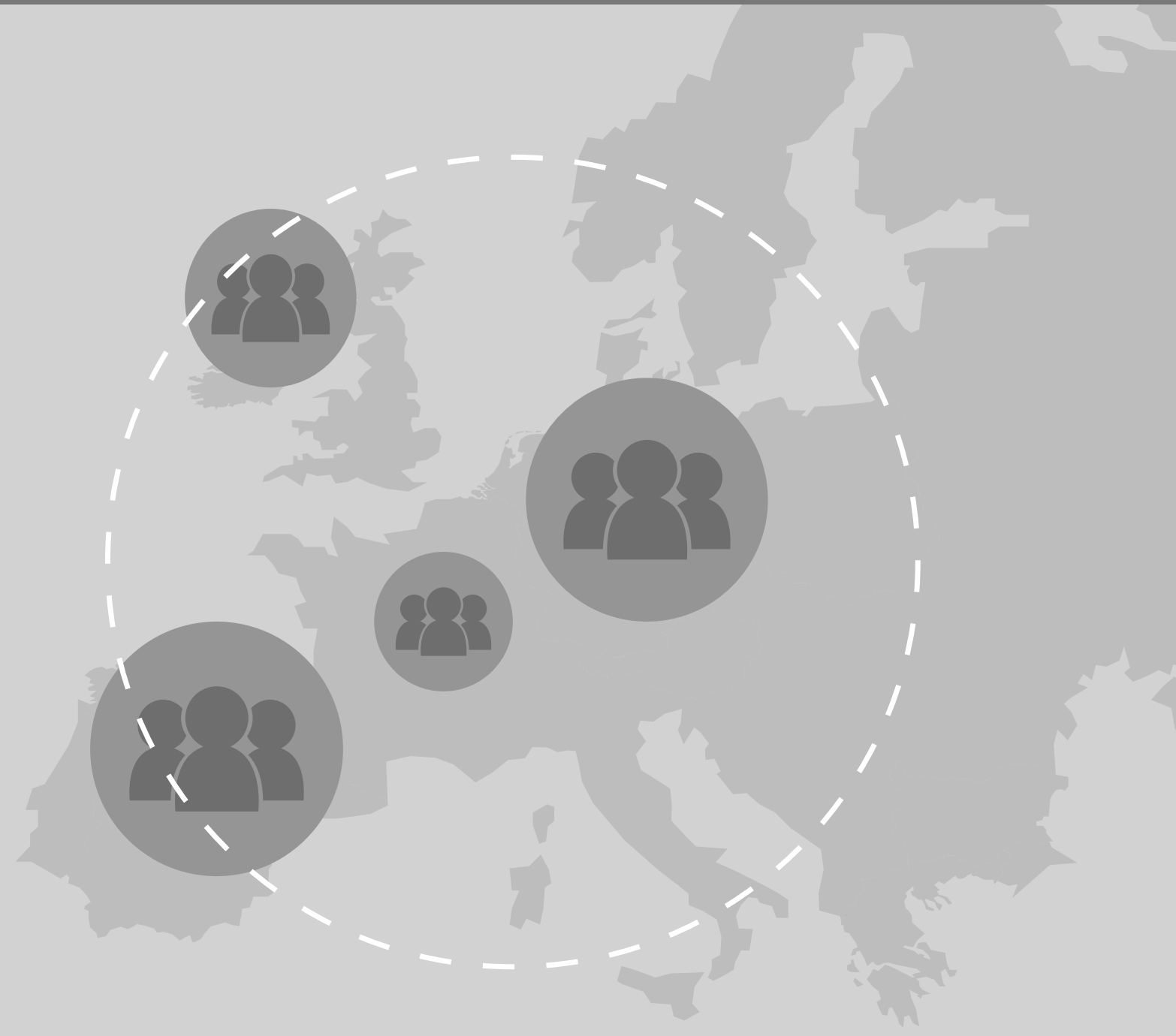




\section{Figures}

Figure 1.1 Results of a search in PubMed concerning 'health literacy' for the period of 1995-2012.

Figure 1.2 European health literacy stakeholders and policy milestones

Figure 1.3 Overview of research questions and research designs to explore how health literacy is defined, measured and advanced in Europe

Figure 2.1 Integrated model of health literacy

Figure 5.1 Levels of general health literacy index by country and for the total sample

Figure 6.1 Data collection flow diagram

Figure 6.2 The integration of health literacy in policy, research and practice in Denmark represented by arenas/sectors and stakeholders

Figure 9.1 Grounded theory on how to develop health literate businesses in the realm of corporate social responsibility

Figure 10.1 Blueprint of Business Action on Health Literacy

Figure 12.1 The conceptual model concerning citizen consultations, health literate populations and systems as pre-requisite for people-centered, coproduction of health

Figure 13.1 Overview of main findings in terms of Health literacy: a neglected European public health disparity 


\section{Tables}

Table 1.1 Key differences between qualitative and quantitative research

Table 2.1 Definitions of health literacy

Table 2.2 The six clusters identified when condensing the definitions from the literature review

Table 2.3 Conceptual models of health literacy

Table 2.4 The matrix with four dimensions of health literacy applied to three health domains

Table 3.1 The European Health Literacy Glossary

Table 4.1 The HLS-EU health literacy matrix

Table 4.2 The characteristics of the focus group sample

Table 4.3 The characteristics of the pre-test sample

Table 4.4 The characteristics of design and the development of HLS-EU-Q

Table 5.1 Descriptive statistics of general health literacy index by country and for the total sample

Table 5.2 Percentages of individuals with limited health literacy in selected vulnerable groups for countries and for the total sample

Table 5.4 Multivariate linear regression model for general health literacy index as dependent variable and socio-demographic indicators as predictors

Table 6.1 Results of the power and leadership analysis: who is important for the advancement of health literacy in Denmark

Table 9.1 Interview guide: health literacy activities for employees as part of corporate social responsibility (CSR)

Annex 1 The HLS-EU-Q47 


\section{Abbreviations}

\begin{tabular}{ll} 
BMWD & The Britisch Merriam-Webster Dictionary \\
CAPHRI & Research school for public health and primary care \\
CAPI & Computer assisted personal interviews \\
CaRe & Netherlands School for Primary Care Research \\
CSR & Corporate Social Responsibility \\
EU & European Union \\
HLS-EU Definition & The European Health Literacy definition \\
HLS-EU Matrix & The European Health Literacy matrix \\
HLS-EU Project & The European Health Literacy project \\
HLS-EU Survey & The European Health Literacy survey \\
HLS-EU-Q & The European Health Literacy survey questionnaire \\
ISCED & International standard classification of education \\
NAAL & National Assessment of Adult Literacy \\
NALA & The National Adult Literacy Agency \\
NOAD & The New Oxford American Dictionary \\
OECD & Organisation for economic cooperation and development \\
PAPI & Paper assisted personal interviews \\
PCA & Principal Component Analysis \\
UNESCO & United Nation Education, Science and Culture Organization \\
WHO & World Health Organisation \\
WHO/EURO & World Health Organisation's European Office \\
& \\
\hline
\end{tabular}




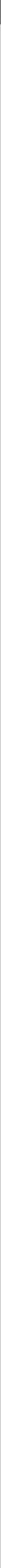




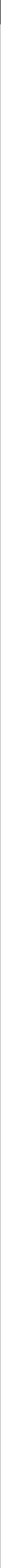


Co-authors

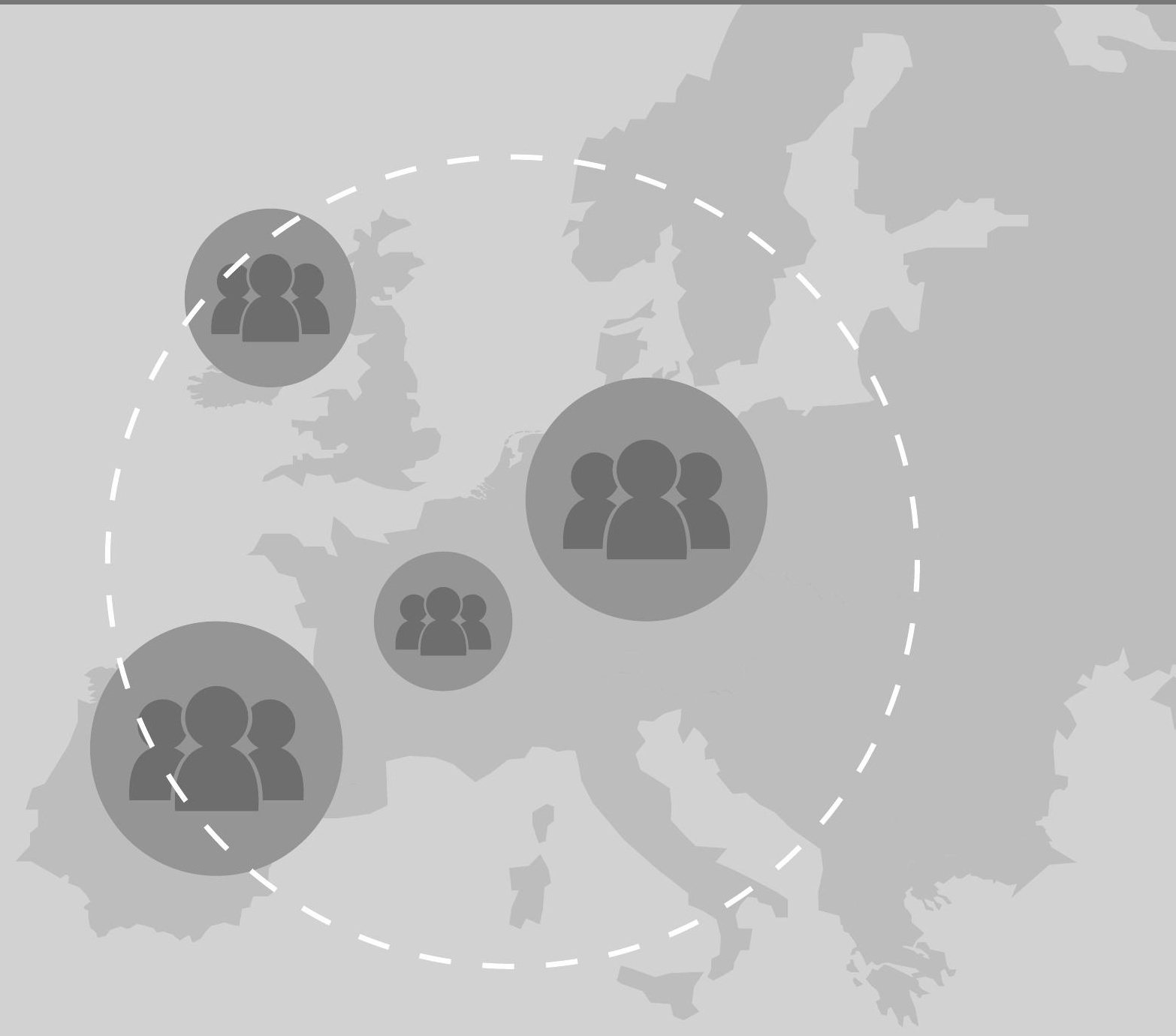




\section{Co-authors contributing to this dissertation}

\begin{tabular}{|c|c|}
\hline DA & Demosthenes Agrafiotis \\
\hline CA & Christoph Aluttis \\
\hline NB & Nolwenn Bertrand \\
\hline HB & Helmut Brand \\
\hline KC & Katarzyna Czabanowska \\
\hline GD & Gerardine Doyle \\
\hline MF & Maria Falcon \\
\hline$J F$ & James Fullam \\
\hline KG & Kristin Ganahl \\
\hline TK & Tanya Kennedy \\
\hline BK & Barbara Kondilis \\
\hline $\mathrm{CM}$ & Charlotte Malvy \\
\hline MM & Monika Mensing \\
\hline $\mathrm{CN}$ & Christine Neumann \\
\hline ON & Ole Nørgaard \\
\hline RO & Richard Osborne \\
\hline RP & Ray Pintus \\
\hline$A R$ & Alexander Rödiger \\
\hline FR & Florian Röthlin \\
\hline PSB & Peter Schröder-Bäck \\
\hline KS & Kristine Sørensen \\
\hline VS & Vivian Stoffels \\
\hline HTM & Helle Therkildsen Mainda \\
\hline KT & Kancho Tchamov \\
\hline EU & Ellen Uiters \\
\hline ZS & Zofia Slonska \\
\hline SVDB & Stephan van den Broucke \\
\hline
\end{tabular}


In terms of health literacy;

we should not be part of the problems,

we should be part of the solutions.

WHO Healthy City Coordinator, United Kingdom 


\section{Summary}

Samenvatting

Resumé

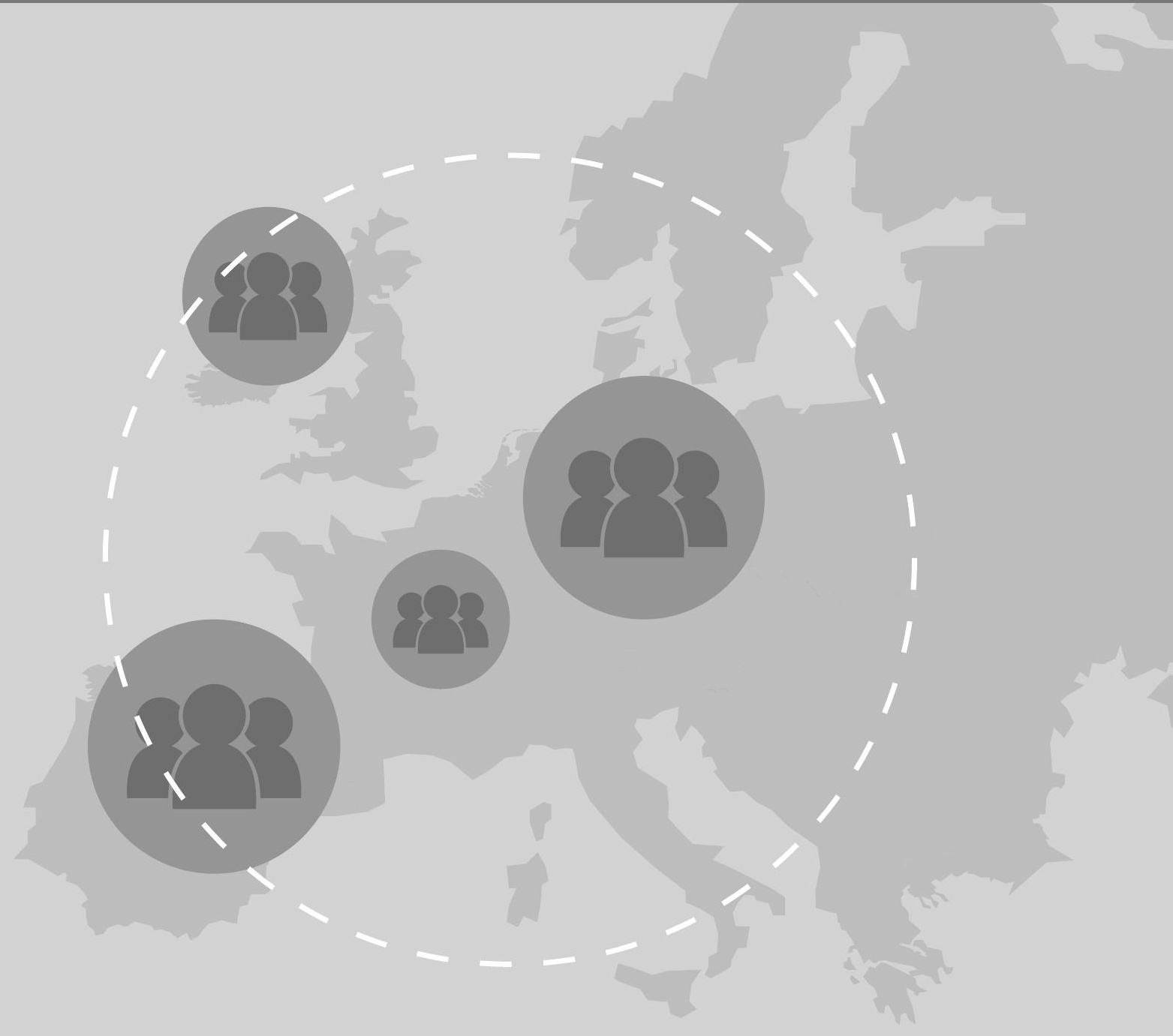




\section{Summary}

\section{Health literacy: a neglected European public health disparity}

The research in this dissertation Health literacy: a neglected European public health disparity aimed at exploring how health literacy as a contemporary challenge to public health could be defined, measured and advanced in Europe. The outcome of the research illustrates that although the field is evolving exponentially, health literacy is still a neglected European public health disparity, which will require an increased attention from researchers, decision-makers and practitioners to overcome. The studies were grouped in three parts: 1) defining health literacy, 2) measuring health literacy and 3) advancing health literacy as part of developing health literate systems, health literate businesses and health literate societies.

The research resulted in eleven key outputs. Notably, the research provided a new 'all-inclusive' definition and conceptual model of health literacy, which can be interpreted from the perspectives of citizens as well as from the perspectives of health systems. The term 'health literacy' proved a challenge to translate within the international and European context, hence, a study was made to explore translations, which in turn generated a European Glossary presenting health literacy in 29 languages. Concerning measuring health literacy in Europe, a questionnaire, the HLS-EU-Q, was developed on the basis of the new definition and conceptual model to measure health literacy in a selection of EU Member States. Subsequently, a survey was conducted in eight countries: Austria, Bulgaria, Germany, Greece, Ireland, the Netherlands, Poland and Spain. The survey indicated that $47 \%$ on average had limited health literacy, although the results varied between the participating countries (29\%-62\%). Concerning health literate systems a case study from Denmark with reference to movers and shakers in the field of health literacy illustrated a wide range of stakeholders involved; however, it also disclosed a vacuum of leadership as none could be classified as designated front runners in advancing health literacy. A specific focus on health professionals in the field of public health genomics revealed that they have to pursue new roles in communication with patients and colleagues. It was argued that health literacy can act as a catalyst for efficient and transparent knowledge transfer and that health professionals ought to consider themselves as knowledge brokers to support better communication when dealing with complex and innovative matters such as for instance public health genomics. Concerning the development of health literate businesses, the research demonstrated how health literacy was an asset for corporate social responsibility by moving the focus from the fitness room to the strategic corporate opportunities determined in the boardroom. A Blueprint for Business Action on Health Literacy was presented to influence social practices concerning health at work. Lastly, the aspect of developing health literate societies was scoped in terms of ethical perspectives 
in the stance of social determinants, quality of life, justice, human rights and the capability approach for human development. In addition, a scope study contributed with a framework on how health literacy can support the development of health literate populations and systems to increase people-centered, co-production of health through the means of citizen consultations.

Essentially, the three parts of research presented in the dissertation reveal an intuitive understanding of the importance of health literacy; yet they also illustrate the divide existing in Europe presently. Some Member States in the European Union are aware of their health literacy status through, for instance, the European Health Literacy Survey, where for others the challenge of limited health literacy in their population is still neglected. While a wide range of stakeholders may be aware of the concept of health literacy or have become aware during the last years' European activities, the political ownership and leadership in terms of advancing health literacy at Member State level as well as at European level, is still overlooked or only partly under development. In the efforts to create health literate systems, businesses and societies the studies included in this dissertation generally disclose health literacy to be a new concept, which has to prove its worth in the European context. The invisibility and lack of knowledge regarding health literacy and its consequences for healthy living and quality of life among professionals and decision-makers seemed to be a bottleneck for further progress. Yet, it is also the impression that the increased focus on health literacy through the work of the HLS-EU Consortium and its collaborating partners has formed a tipping point towards an exponential growth in activities. Hence, it can be concluded that the European added value of the research is already present, although it is unevenly distributed at present.

The European health literacy divide, where almost one in two possess limited health literacy, calls for action. To overcome this widely neglected European public health disparity, two complementary objectives are essential in the future and should underpin all efforts; namely the aim of creating health literate populations as well as health literate systems and societies in Europe. Only when both objectives are being considered, it is possible to align the competency of the citizens with the demands of the systems to create a more efficient match in terms of interaction and peoplecenteredness. Notably, as Alvin Toffler stated: 'The illiterate of the $21^{\text {st }}$ century will not be those who cannot read and write, but those who cannot learn, unlearn and relearn". Hence, the detected neglect of health literacy in many European countries must not lead to neglect to act. Health literacy is a cross-cutting issue, which addresses many current topics on the European health agenda such as communicable, noncommunicable and chronic diseases, cross-border healthcare, use of new technologies, self-management etc. The evidence base need to be further established for the whole of Europe and the concept and measurement integrated in European research, policy 
and practice. The European endeavor to overcome limited health literacy may be invisible for some and in its infancy for others. However, the potential to make a change is higher than ever; if we dare to compare and do better - because health literacy matters! 


\section{Samenvatting}

\section{Gezondheidscompetenties: een veronachtzaamd verschil in de volksgezondheid in}

Europa

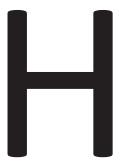

et onderzoek, waarop deze dissertatie is gebaseerd, richtte zich op het onderzoek naar de wijze waarop gezondheidscompetenties als een hedendaagse stimulans voor volksgezondheid gedefinieerd, gemeten en bevorderd zouden kunnen worden in Europa. De resultaten van het onderzoek illustreren dat, ondanks het feit dat het gebied zich exponentieel ontwikkelt, gezondheidscompetentie nog steeds een ongelijkheid kent die, voor wat betreft volksgezondheid in Europa, verwaarloosd wordt. Het zal in toenemende mate aandacht vergen van onderzoekers, beleidsvormers en in de praktijk om deze ongelijkheid te verminderen.

De studie bevat drie onderdelen: 1) definiëren van gezondheidscompetenties, 2) meten van gezondheidscompetenties en 3 ) bevorderen van gezondheidscompetenties als onderdeel van het ontwikkelen van gezondheidscompetentiesystemen, ondernemingen verband houdende met gezondheidscompetenties en gezondheidscompetente samenlevingen. Het onderzoek heeft elf belangrijke resultaten opgeleverd.

Het onderzoek verschafte met name een nieuwe 'allesomvattende' definitie en een conceptueel model van gezondheidscompetenties, dat zowel vanuit het perspectief van de burger alsook vanuit het gezondheidssysteem gezien kan worden. De term 'health literacy' bleek een ware uitdaging te zijn om te vertalen binnen de internationale en Europese context. Vandaar dat er een studie is verricht om vertalingen te onderzoeken, die op hun beurt resulteerden in een Europese verklarende woordenlijst in negenentwintig talen.

Om de gezondheidscompetenties in Europe te kunnen meten werd een vragenlijst opgesteld, de HLS-EU-Q, ontwikkeld op basis van de nieuwe definitie en het conceptuele model om gezondheidscompetenties te meten in een selectie van EU-lidstaten. Vervolgens werd een onderzoek uitgevoerd in acht landen: Oostenrijk, Bulgarije, Duitsland (Noordrijn-Westfalen), Griekenland, lerland, Nederland, Polen en Spanje. Het onderzoek gaf aan dat gemiddeld $47 \%$ beperkte gezondheidscompetenties had. Hierbij dient te worden opgemerkt dat de uitkomsten varieerden tussen de deelnemende landen (29\%-62\%).

Een diepgaande analyse in Denemarken laat zien dat, voor wat betreft 'movers \& shakers' (belangrijke politici en zakenlieden), een breed scala aan belanghebbenden op het gebied van gezondheidscompetenties betrokken is. De analyse gaf echter ook een vacuüm van leiderschap aan, aangezien niemand aangeduid kon worden als koploper voor wat betreft het bevorderen van gezondheidscompetenties. Een specifieke focus op gezondheidsdeskundigen op het gebied van volksgezondheid met betrekking tot genomica onthulde dat men nieuwe rollen in communicatie met patiënten en collega's 
moet nastreven. Verder kwam aan het licht dat dat gezondheidscompetenties als een katalysator kunnen werken voor efficiënte en transparante kennisoverdracht en dat gezondheidsdeskundigen zichzelf zouden moeten beschouwen als kennismakelaars om een betere communicatie te kunnen bewerkstellingen als ze te maken hebben met complexe en innovatieve zaken zoals, bijvoorbeeld, volksgezondheid die zich richt op genomica. Voor wat betreft de ondernemingen op het gebied van gezondheidscompetenties, liet het onderzoek zien hoe gezondheidscompetenties een groot goed zijn voor collectieve de maatschappelijke verantwoordelijkheid door de focus te verleggen van de fitnessruimte naar de strategische institutionele mogelijkheden zoals die in de directiekamer worden vastgesteld (Corporate Social Responsibility). Een blauwdruk voor Business Action on Health Literacy werd gepresenteerd om maatschappelijke activiteiten met betrekking tot gezondheid op het werk te beïnvloeden. Ten slotte werd het aspect inzake de ontwikkeling van een gezondheidscompetente maatschappij gezien in termen van ethische perspectieven in het licht van bepalende factoren, kwaliteit van leven, rechtvaardigheid, mensenrechten en de zgn. capability approach (de capability approach stelt de menselijke waardigheid centraal en verdedigt het idee van de menselijke keuzevrijheid en van de mensenrechten) voor de menselijke ontwikkeling. Aanvullend hieraan droeg een omvangrijke studie bij, aan een raamwerk waarin is aangegeven hoe gezondheidscompetentie de ontwikkeling kan ondersteunen van gezondheidscompetente populaties en systemen in een mensgeoriënteerde samenwerking van gezondheid door het verhogen van burgerconsultaties.

Essentieel is dat de drie onderdelen van de studie zoals die in deze dissertatie gepresenteerd worden, een intuïtief begrip voor het belang van gezondheidscompetenties aan de dag legt. Er wordt echter ook in aangetoond dat het huidige Europa hierin een verschil kent. Sommige lidstaten in de Europese Unie zijn zich bewust van hun gezondheidscompetentie door, bijvoorbeeld, de European Health Literacy Survey, maar andere lidstaten onderschatten nog steeds de gevolgen van beperkte gezondheidscompetenties onder hun bevolking. Een grote groep belanghebbenden moge zich dan wel bewust zijn van het concept van gezondheidscompetenties of zijn, gedurende de Europese activiteiten van de laatste jaren, van het belang ervan overtuigd geraakt, de politieke verantwoordelijkheid en politiek leiderschap voor wat betreft het verbeteren van gezondheidscompetenties is, op het niveau van de lidstaten alsook op Europees niveau, nog steeds niet, of slechts ten dele, onderkend. In de poging om gezondheidscompetente systemen, bedrijven en maatschappijen te creëren, tonen de studies in deze dissertatie over het algemeen aan dat gezondheidscompetenties als zodanig een nieuw concept is dat zijn sporen moet verdienen in de Europese context. Het, voor deskundigen en beleidsmakers, niet-zichtbaar zijn en het gebrek aan kennis met betrekking tot gezondheidscompetenties en de daarmee samenhangende consequenties voor het op een gezonde wijze kunnen leven en de kwaliteit van leven, leek een hin- 
dernis te zijn voor verdere voortgang. De verbeterde focus op gezondheidscompetenties heeft nochtans, dankzij het werk van het HLS-EU Consortium en de samenwerkende partners, een omslagpunt veroorzaakt ten faveure van een exponentiële groei in activiteiten. Vandaar dat geconcludeerd kan worden dat de toegevoegde waarde van het onderzoek, voor Europa, reeds zichtbaar is, ook al is het momenteel niet evenredig verdeeld.

Het verschil in gezondheidscompetenties binnen Europa, waar bijna een op de twee beperkte gezondheidscompetenties heeft, vraagt om actie. Om dit zwaar verwaarloosde verschil in Europese volksgezondheid te ondervangen, zijn, in de toekomst, twee aanvullende doelstellingen essentieel en deze zouden alle inspanningen moeten ondersteunen: namelijk het doel om gezondheidscompetente populaties, gezondheidscompetente stelsels en maatschap-pijen te creëren in Europa. Alleen indien beide doelstellingen in acht worden genomen, is het mogelijk om de competentie van de burger in lijn te brengen met de vereisten van de stelsels om een efficiëntere match te creëren voor wat betreft interactie en de mens als uitgangspunt. Zoals Alvin Toffler al stelde: 'De analfabeten van de 21 e eeuw worden niet veroorzaakt door het niet kunnen lezen en schrijven, maar door het niet kunnen leren, afleren en her-leren'. Het aan het licht gebrachte verzuim, van veel van de Europese landen, om aandacht te besteden aan gezondheidscompetenties mag derhalve niet leiden tot het verzuim om te handelen. Gezondheidscompetentie heeft betrekking op een groot aantal zaken die heden ten dage op de Europese agenda staan, zoals overdraagbare, niet-overdraagbare en chronische ziektes, grensoverschrijdende gezondheidszorg, gebruik van nieuwe technologieën, zelfbestuur etc. Het draagvlak voor hetgeen dat uit het onderzoek duidelijk is geworden, dient verder te worden vergroot in geheel Europa, waarbij het concept en de wijze van beoordeling dient te worden geïntegreerd in Europees onderzoek, beleid en uitvoering. De Europese pogingen om beperkte gezondheidscompetenties te boven te komen moge duidelijk zijn voor de een, maar bij de ander nog in de kinderschoenen staan. Hoe dan ook; het vermogen om een verandering te bewerkstelligen is groter dan ooit, mits we het aandurven om te vergelijken en het beter te doen; gezondheidscompetenties zijn immers van levensbelang! 


\section{Resumé}

\section{Sundhedskompetence: en forsømt europæisk ulighed i folkesundhed}

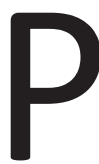

hD-afhandlingen Sundhedskompetence: en forsømt europæisk ulighed $i$ folkesundhed har til formål at belyse, hvordan befolkningers sundhedskompetence kan defineres, måles og fremmes i Europa. På trods af at området er i en rivende udvikling, viser afhandlingen at sundhedskompetence-området er en forsømt europæisk ulighed, som det vil kræve en $\varnothing$ get opmærksomhed i forskning, politik og praktik at få udlignet. Undersøgelserne, der ligger til grund for afhandlingen, er delt i tre grupper: 1) definition af sundhedskompetence-begrebet, 2) måling af sundhedskompetence-niveauet i europæiske befolkninger og 3) fremme af sundhedskompetencer som led $\mathrm{i}$ at udvikle sundhedskompetencefremmende systemer, virksomheder og samfund. Forskningen resulterede i elleve nøgleudfald. Først og fremmest blev der udviklet en ny 'alt-omspændende 'sundhedskompetence-definition og -model, som kan forstås både på systemisk og individuelt niveau. Fra et internationalt og europæisk perspektiv viste det sig at være en udfordring at oversætte det engelske begreb health literacy til andre sprog. Der blev derfor foretaget en sproganalyse, som resulterede i en miniordbog med oversættelser af begrebet til 29 europæiske sprog. For at måle sundhedskompetence-niveauet i udvalgte lande i Europa blev der udviklet et nyt spørgeskema, HLS-EU-Q, på basis af den ny-udviklede definition og model. Efterfølgende fandt den europæiske sundhedskompetenceunders $\varnothing$ gelse sted i otte lande: Bulgarien, Grækenland, Holland, Irland, Polen, Spanien, Tyskland og $\emptyset$ strig. Unders $\varnothing$ gelsen viste at $47 \%$ af befolkningerne i gennemsnit havde et begrænset sundhedskompetenceniveau, selvom resultaterne varierede landene imellem (29-62\%).

Vedrørende sundhedskompetencefremmende systemer blev der som et eksempel foretaget en analyse af hvem, der er 'movers og shakers' indenfor sundhedskompetenceområdet i Danmark. Analysen viste at selvom en bred gruppe organisationer og institutioner er involveret, så blev der også identificeret et ledelsesvakuum, da ingen kunne karakteriseres som toneangivende og førende på området på nuværende tidspunkt. Et specifikt fokus på sundhedsprofessionelle indenfor 'public health genomics'-området angav at sundhedsfagligheden kræver nye roller indenfor kommunikation med patienter og kolleger. I den henseende kan bevidstgørelsen om sundhedskompetencer bruges som katalysator for en mere effektiv og transparent form for videns-deling; hvor sundhedsprofessionelle bliver vidensformidlere, der kan skabe en bedre kommunikation, når man har med komplekse og innovative områder at gøre såsom 'public health genomics'. I forhold til udviklingen af sundhedskompetencefremmende virksomheder viste undersøgelserne at ved at flytte sundhedsperspektivet fra $\varnothing$ velserne i fitnesslokalet til de strategiske beslutninger i 
bestyrelseslokalet kunne sundhedskompetenceudvikling være en vigtig brik i virksomhedens sociale ansvar (Corporate social responsibility - CSR). Der blev ligeledes udviklet en ny strategi, om hvordan man kan skabe sundheds-kompetencefremmende virksomheder. Som et sidste område blev de etiske fordringer forbundet med udviklingen af sundhedskompetencer unders $\varnothing \mathrm{gt}$ i forhold til sociale determinanter, livskvalitet, retfærdighed, menneskerettigheder og Nussbaum's kapacitetsperspektiv på menneskelig udvikling. Derudover blev der lavet en unders $\emptyset$ gelse af hvilke nationale praksis, der findes, for hvordan sundhedskompetence kan styrkes systemisk og på befolkningsniveau for at skabe et centralt menneskefokus i samarbejdet om at skabe sundhed gennem borger inddragelsese.

De tre undersøgelsesdele, der præsenteres i afhandlingen, angiver en intuitiv forståelse for vigtigheden af sundhedskompetence for sundhed og livskvalitet; men de illustrerer også den forskel, der eksisterer i Europa i dag. Nogle EU medlemslande har adgang til til sundhedskomptence-evidens, hvis de for eksempel deltog i den europæiske sundhedskompetenceundersøgelse. Mens det for andre lande gælder at området har været forsømt eller overset. Hvor der synes at være en bred vifte af interessenter, som er bevidste om sundheds-kompetencebegrebet elle er blevet bevidste gennem de sidste års europæiske aktiviteter, så er det politiske ejerskab og lederskab stadig enten negligeret eller stadig under udvikling på europæisk niveau og i mange europæiske lande. I bestræbelserne på at skabe sundhedskompetencefremmende systemer, virksomheder og samfund har studierne i denne afhandling afdækket at sundhedskompetencebegrebet generelt opfattes som et nyt koncept, der skal bevise sit værd i en europæisk kontekst. Den manglende viden og manglende synlighed blandt sundhedsprofessionelle og beslutningstagere vedrørende sundhedskompetence og dets konsekvenser for livsstil og livskvalitet har vist sig at være en flaskehals for den videre udvikling. Men det er dog også indtrykket, at den øgede fokus på området har skabt et vendepunkt, således at området nu er i vækst. Den øgede fokus gennem det europæiske sundhedskompetence projekt har givet således afkast, men afkastet er dog ikke nået til alle lande.

Den europæiske sundhedskompetenceforskel, hvor næsten en ud af to mennesker i gennemsnit har et begrænset sundhedskompeteceniveau, kalder på handling. For at overvinde denne udbredte fors $\emptyset$ mte europæiske ulighed i folkesundheds er der to mål, der skal nås, nemlig både at udvikle befolkningernes sundhedskompetence og at skabe sundhedskompetencefremmende systemer og samfund. Kun når begge mål opfyldes er det muligt at lave et komplet sammenspil mellem borgernes færdigheder og sundhedssystemets og samfundets krav. Som Alvin Toffler sagde: Analfabeterne i det 21. århundrede vil ikke være dem som ikke kan skrive og læse, men dem som ikke kan lære, aflære og lære på ny. Derfor, må den påviste forsømmelse af sundhedskompetenceområdet i europæiske lande ikke lede til endnu en forsømmelse af 
handling. Sundhedskompetencefeltet er et tværfagligt område som relaterer sig til mange emner på den europæiske sundhedsdagsorden såsom smitsomme, ikkesmitsomme og kroniske sygdomme, grænseoverskridende sundhedsservice, nye teknologier, selvhjælp og patientuddannelse og så videre. Evidensen bør udbygges i hele Europa og konceptet og monitorering bør integreres i europæisk forskning, politik og praktik. Denne europæiske bestræbelse på at overvinde forskelle i sundhedskompetencer er måske ikke synlige for alle, og kun i sin vorden for andre, men potentialet til at skabe en forandring er større end nogensinde, hvis vi blot $t \varnothing r$ at sammenligne og forbedre tilstanden - og forstå at sundhedskompetencer er vigtige! 
It's a dangerous business, Frodo, going out of your door, you step on the Road, and if don't keep your feet;

there is no knowing where you might be swept off to.

Bilbo Baggings, Lord of the Rings 
Acknowledgements

\section{Dankwoord}

Tak

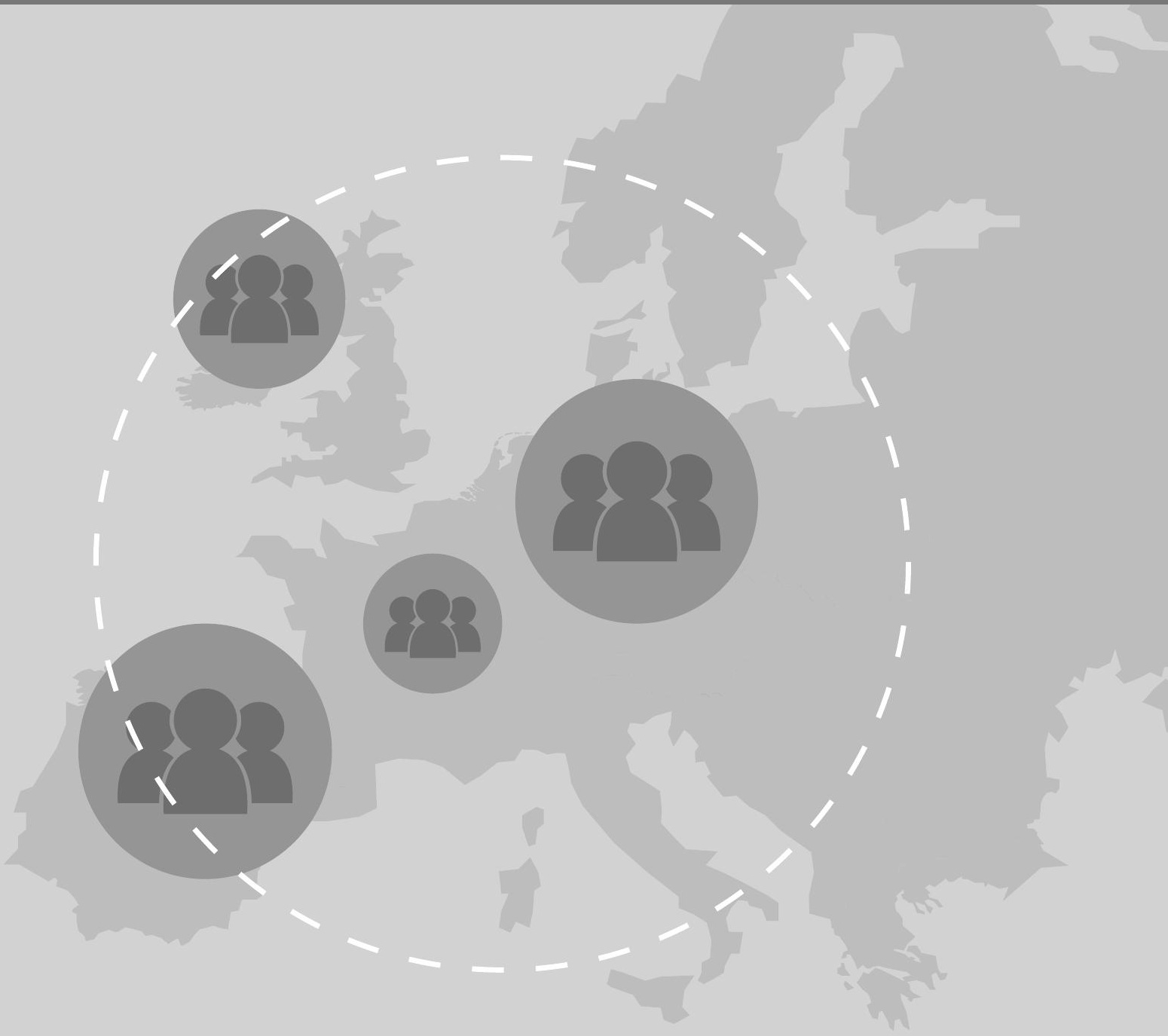




\section{Acknowledgements - Dankwoord - Tak}

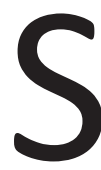

ince autumn 2009 I have been dedicated to write the PhD dissertation on health literacy in Europe as the first candidate from the Department of International Health, Faculty of Health, Medicine and Life Science at Maastricht University, the Netherlands. It has been an exciting challenge and I wish to thank my promotor Prof. Helmut Brand for encouraging me to write the dissertation in parallel with my job as researcher and coordinator of the European Health Literacy project (HLS-EU) and for allowing me to engage in not only the research, but also the valorisation of the results. It has been rewarding to work on promoting European health literacy in the cross-fire of research, policy and practice; I am pleased to see what impact the initiatives have achieved; especially in terms of the three awards we received in 2012. I also thank my co-promotors, Prof. Stephan Van den Broucke and Dr. Peter Schröder-Bäck, for the full support you have provided me throughout the research period. Your patience and commitment in terms of the publication processes have been valuable, especially at times when the activities concerning societal impact of the European Health Literacy project was dominating my work.

During the years we have developed a fruitful PhD fellowship within the Department of International Health and I thank all PhD fellows, Nicole Rosenkötter, Timo Clemens, Christoph Aluttis, Alexandra Ziemann and Beatrice Scholten as well as our external PhD colleagues for sharing the joy and sorrow as PhD candidate and for encouraging the continuing work, milestone by milestone, until finally the dissertation could be handed in. In addition, a sincere gratitude goes to all my colleagues within the Department of International Health; especially Daniela Popa, Anita Creusen, Pien Struijk, Matt Commers, Thomas Kraft, Kai Michelsen, Esther Slits, Kasia Czabanowska and Jaques Scheres; who have followed my progress and contributed to the work through your daily support. I also wish to expand the thanks to the students of European Public Health, Vivian Stoffels, Benjamin Tsiflidis, Vera van Heel and Ann Borg, who assisted me in data collection and analysis for the research at various stages.

To all my colleagues in the European Health Literacy project there is a sincere and grateful applause for your assistance in ensuring the results and the outcomes on which this dissertation is partly based. It has been a pleasure to collaborate with you, Jürgen Pelikan, Florian Röthlin, Kristin Ganahl, Gerardine Doyle, James Fullam, Kenny Cafferkey, Zofia Slonska, Monika Mensing, Gudula Ward, Ellen Uiters, Iris van der Heide, Mariëlle Droomers, Jantine Schuijt, Kancho Tchamov, Alex Tchekov, Maria Falcon, Barbara Kondilis, Eli Eionnides and Demosthenes Agrafiotis. I am pleased that we, together, have made The European Health Literacy project a tipping point for the advancement of health literacy in Europe and received the European Health award for 
our efforts. In addition, I am grateful that we have been able to continue the collaboration in many aspects.

As a spin-off to the European Health Literacy project, I got involved in the Joint Venture on Health Literacy - Introducing health literacy as business action and corporate social responsibility within CSR Europe. It has been interesting to work with the business partners in the steering group and I wish to forward my thanks to Christine Neumann, Stefan Crets and Jan Noterdaeme from CSR Europe, Alexander Rödiger of MSD, Cécile Duprez Naudy and Stephan Cossandey of Nestlé, Ray Pinto and Elena Bonglodi of Microsoft, Charlotte Malvy and Nolwenn Bertrand of Edenred and Tanya Kennedy of BITC for fruitful discussions and hard work to implement health literacy at the work place. The launch of the Blueprint in the European Parliament in March 2013 was the best recognition, we could achieve for our efforts.

During the involvement in the European Health Literacy Project I have had the opportunity to meet and speak to many distinguished experts within the field of health literacy. I thank you for all the inspirational talks and for the hospitality you have provided on my travels to Nairobi, Zürich, Geneva, Southampton, Kiev, Washington, New York, Jerusalem, Sandness, Liverpool, Lisbon, Essen, Hannover, Malta, Lodz, Gastein, London, Copenhagen, Utrecht, Amsterdam, Dublin, Sofia, Vienna, Brussels, Strasbourg, Oslo, Göteborg, Baku and where else I have been in the last years to promote health literacy. Wayne Mitic, Diane Levin, Ilona Kickbusch, Don Nutbeam, Richard Osborne, Luis Saboga Nunes, Thomas Abel, Rima Rudd, Ruth Parker, Michael Paasche-Orlow, Michael Wolf, Andrew Pleasant, Jolie Haun, Lauren McCormack, Melissa Valero, Franklin Apfel, John Lucy, Suzanne Suggs, Helle Terkildsen Maindal, Ole Nørgaard, Lars Kayser, Kjell Sverre Pettersen; Lena Mårtensson, Josefin Wångdahl, Per Tillgren, Karin Ringsberg, Bengt Linström, Angela Brand, Jane Wills, Gill Rowlands, Mirjam Fransen, Marie-Louise Essink-Bot, Jorien Bakx, Jany Ramakers, Nicola Bedlington, Karin Kadenbach, Peter Chang, Richard Hawkey, Ellen te Porten, Zjelco Felder and many others, who I may not have mentioned here, but equally deserve the recognition for supporting me on this journey.

Coordinating a European research project and writing a dissertation at the same time demands a special attention from the home front. I am sincerely grateful to my family in Denmark; my parents Inna and Torsten Sørensen and my sister Anne-Sophie Daugaard-Hansen; my family in law: Jette and Erik Fredskov, Ernst and Lone Hansen, Pernille and Heidi Rømer Hansen as well as our friends from near and far for helping us to have the ends meet; in particular Signe Beck-Nielsen, Anders Bojesen, Ulrikand Adeline Skov, Jonas Sprogøe, Katja Holm, Casper and Kira Leuenhagen, Klaas Boer, Irene Wormst, Mien Gerards, Anneke Vleugels, Paul van der Val, Sigrid de Vrede, Maja Schmitt and Richard Heyn. However, to my sons Rasmus and Jakob and my husband 
Jesper I owe my most sincere thanks and love, because without your endurance I would not have succeeded this endeavour.

Var livet en dans på roser

Var alt da mon bedre end nu?

Hvis ej der var noget at kæmpe for

Hvad var da vel jeg og du.

Kaalund 
We must leave our mark on life while we have it in our power.

Karen Blixen 
Curriculum Vitae

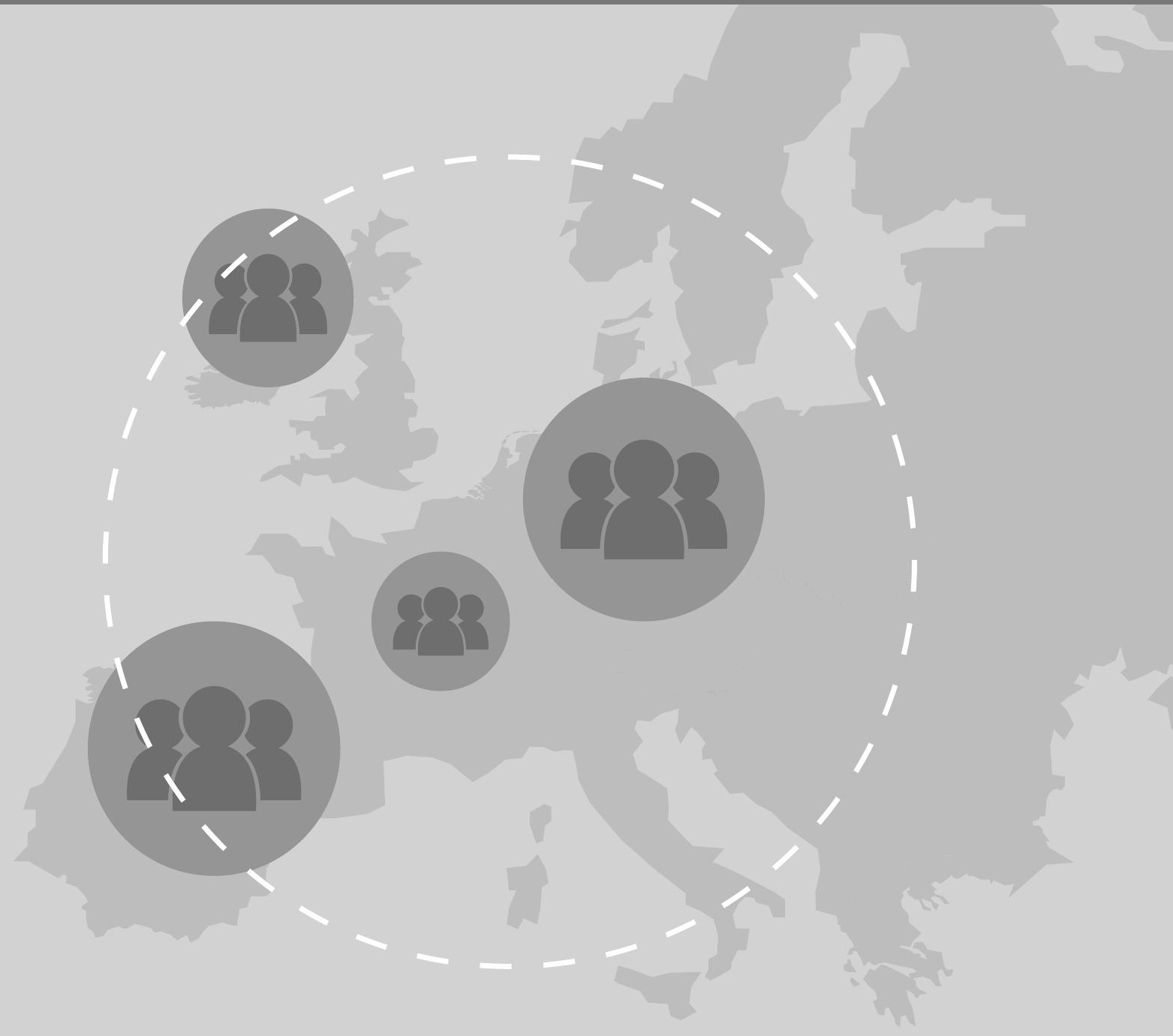




\section{Curriculum Vitae}

K

ristine Sørensen was born in 1973 in Denmark and grew up in Kolding. During her childhood she attended Kolding Realskole and took her college degree from Munkensdam Amtsgymasium. After college she spent a year on social service for the World Association of Girl Guides and Girl Scouts at the world centres in London and in Guernavaca, Mexico. She continued her studies at the Medical School from 1993 to 1998 at Odense University in Denmark; before changing her career path to study Public Health Science, where she graduated her Bachelor in 2002 and her Master of Public Health Science in 2005 from Copenhagen University. Her graduation project, conducted with Lene Hammer-Helmich, on poor children's perception of health in Denmark got national media coverage and had a significant political impact. During her public health studies she worked in healthcare, childcare and as study advisor at the university. She also did freelance public health consultancy. After her graduation she worked as project manager for TrygFonden on health and safety projects before moving to the Netherlands in 2006 with her family. Her career continued at Maastricht University, where she became lecturer and developed the curriculum of the second year in the European Public Health Bachelor Programme along with the tasks of being module, semester and portfolio coordinator. Furthermore, she planned two study trips to the Jagiellonian University for the European Public Health students and pursued the university teaching qualification (BKO) in Dutch. In 2009 she became researcher and the project coordinator for the European Health Literacy project. Other related projects were the Joint Venture on Health Literacy; which integrates health literacy into business actions and corporate social responsibility; the Diabetes Literacy project supported by the European Commission; a study on health literacy and the right to access to health commissioned by the Council of Europe as well as a concept mapping study for the sub-group on Health Literacy within the Healthy Cities Network of the World Health Organisation. In parallel she began the PhD trajectory within CAPHRI; the research school for public health and primary care by the end of 2009 and followed the executive course on global health diplomacy from the Graduate Institute of International Developments in Geneva. During the past years she has acted as advisor on health literacy for numerous national, European and international organisations and has been an invited guest lecturer to several European universities. The European Health Literacy project has been granted with three awards, among others the European Health Award for the outstanding social and political impact of the European health literacy project. Kristine Sørensen thrives in international environments and prefers working with cross-cutting health and human development issues at regional, European or global levels. 
She engages in the civil society and community and values her time with her family and friends. Her social commitment has engaged her in honorary positions throughout the years. In the 1990s she served at the national board of the Green Girl Guides in Denmark as international commissioner; and she was elected to the World Board of the World Association of Girl Guides and Girl Scouts from 1993-1996. As world board member she was engaged in organizing two world youth fora and several youth consultations for the United Nations as well as various international trainings, camps and seminars for young leaders. Later she became the vice-chairman in the advisory board for Pelikanen, a kindergarden in Copenhagen. In the Netherlands she became member of the board of prooSes, a foundation for nine schools in Limburg, which later merged to the foundation Kindante, which include 55 schools in Limburg and where she is now acting as member of the board of commissioners. She is also an active member of Rotary in the local community. Her hobbies include literature, contemporary art, photography, travelling, mountain biking and scouting. 


\section{Health literacy related publications}

Sørensen K, Van den Broucke S, Pelikan JM, Fullam J, Doyle G, Slonska Z, Kondilis B, Stoffels V, Osborne R, Brand $\mathrm{H}$ on behalf of the European Health Literacy Project Consortium (HLS-EU): measuring health literacy in populations: illuminating the design and the development process of the European Health Literacy Survey Questionnaire (HLS-EU-Q), BMC Public Health,; in press

McCormack L, Haun J, Sørensen K, Valerio M: research agenda. Journal of Health Communication. 2013; in press

Sørensen, K., Noergaard, O \& Maindal, HT. Behov for mere forskning i patienters sundhedskompetence. Ugeskrift for læger. 2013 - E-pub.

Noergaard, O, Sørensen, K., Maindal, HT \& Keyser, L. Måling af patientens sundhedskompetence kan bedre kommunikation i sundhedsvæsenet. Ugeskrift for læger - E-pub.

Sørensen K., Schuh B., Stapleton G., \& Schröder-Bäck P. Exploring the ethical scope of health literacy - A critical literature review. Albanian Medical Journal, 2013; 2 71-83.

Toçi E., Burazeri G., Sørensen K., Jerliu N., Ramadani N., Roshi E., \& Brand H.. Health Literacy and Socioeconomic Characteristics among Older People in Transitional Kosovo. British Journal of Medicine and Medical Research. 2013:3(4).

Collaborative Venture on Health Literacy of CSR Europe: Blueprint on Business Actions of Health Literacy. CSR Europe, 2013.

Sørensen $\mathrm{K}$ and Brand $\mathrm{H}$ : Health literacy lost in translation: Introducing the European Health Literacy Glossary. Health Promotion International. 2013. M

Van der Heide I, Rademakers J, Schipper M, Droomers M, Sørensen K, Uiters E. Health literacy of Dutch adults: a cross sectional survey. BMC Public Health 2013(1):179.

Sørensen K: Health literacy - the cornerstone of future health. $1^{\text {st }}$ National Conference on Patient Safety. National Council of Patient Safety. 2013, Ukraine.

Schröder-Bäck P, Clemens T, Michelsen K, Schulte in den Bäumen T., Sørensen K, Borret $\mathrm{G}$ and Brand $\mathrm{H}$ : Public health ethical perspectives on the values of the European Commission's white paper "Together for Health". Central European Journal of Public Health. 2012; 20 (2): 95-100.

Sørensen K, Van den Broucke, S, Fullam J, Doyle G, Pelikan J, Slonska Z, Brand H: Health literacy and public health. A systematic review and integration of definitions and models. BMC Public Health. 2012; 80:12.

Sørensen $\mathrm{K}$ and Brand $\mathrm{H}$ : Health literacy - A strategic asset for corporate social responsibility. Journal of health communication. 2011; 16 (3). 
Sørensen $\mathrm{K}$ and Brand $\mathrm{H}$ : Health literacy: The essential catalyst for the responsible and effective translation of genome-based information for the benefit of population health. Public Health Genomics. 2011; 14 (4-5).

Sørensen K: Health literacy driving change towards equity and sustainability: Scenarios and trends, trade-offs and health attitudes. IHDP Update 1-2011.

\section{Health literacy related presentations}

Sørensen K, Apfel F, \& Kickbusch, I. Health literacy: why making cities more health literate matters. WHO European Healthy Cities Business and Technical Conference. 20.09.2013, Izmir, Turkey.

Sørensen K. Teach-In: Health literacy. WHO European Healthy Cities Business and Technical Conference. 20.09.2013, Izmir, Turkey.

Sørensen K. Is health literacy a new frontier for promoting equity and health? IUHPE Conference 25.08.2013, Pattaya, Thailand.

Sørensen K. Health literacy and non-communicable/chronic disease-research, practice and policy perspectives. 25.08.2013, Pattaya, Thailand.

Sørensen K. Avoiding "the emperor's new clothes" in health literacy - a critical view. 25.08.2013. Pattaya, Thailand.

Sørensen K. The concept of health literacy. Healthy Lifestyles. Summer school. National School of Public Health. 15.07.2013. Lisbon, Portugal.

Sørensen K. Health literacy and citizen consultations. Workshop on the right to health protection. Center for public health and reforms. 10.07.2013. Baku, Azerbaijan.

Sørensen K. Healthy workforce. Healthy society. Investing in health literacy as an asset for the future. Vanbreda International. 16.06.2013. Gent, Belgium.

Sørensen K. Health literacy in Europe. National School of Public Health. 11.04.2013. Maastricht/Lisbon, Portugal.

Sørensen K. The role of health literacy in professional knowledge brokering. Innovation and Patient Access to Personalised Medicine. European Alliance for Personalised Medicine in collaboration with the Irish EU Presidency. 21.03.2013, Dublin, Ireland

Sørensen K. The concept of Health Literacy and Measuring of Health Literacy. Health Literacy Sub-group meeting of the Healthy Cities network. 19-20.03.2013. Liverpool, United Kingdom.

Sørensen K. Health Literacy - the cornerstone of future health. National Patient Safety Conference. 31.11.2012, Kiev, Ukraine. 
Neumann C, Kennedy K, Sørensen K: Business Action on Health Literacy - Innovative initiatives to improve the health literacy of employees - Expert Webinar. 14.11.2012, CSR Europe, Belgium.

Sørensen K. Health literacy on the European health agenda. The European Health Conference. 9.11.2012, Malta.

Sørensen K. Improving coherence between health literacy frameworks and measures. Annual Health Literacy Conference (HARC). 22.10.2012, Bethesda, United States.

Sørensen K. The European Health Literacy Survey. Diversity Compared. Master Programme of European Public Health. 19.10.2012, Maastricht University, the Netherlands.

Sørensen K. The European Health Literacy Survey. Round Table on Health Literacy. 24.09.2012, Institute of Medicine, New York, United States.

Sørensen K. and Brand H., The European Health Literacy Survey. Workshop: "Gesundheitskompetenz: Wissensbezogene vs. erfahrungsbezogene Dimensionen“; Association of Social Medicine and Prevention, 13.09.2012; Essen, Germany.

Sørensen K., Schroeder-Baeck P., Brand H. Health literacy, equity and ethics. Workshop. ESHMS \& DGMS. 01.10.2012, Hannover, Germany.

Sørensen K. Health literacy as an asset for corporate social responsibility. Health literacy conference. 22.05.2012, University of Southampton, Southampton, United Kingdom.

Sørensen K., Brand H. Health literacy in Europe. Breakfast meeting. 09.05.2012. The European Parliament, Brussels, Belgium.

Sørensen K. Health literacy in Europe. Conference on patient empowerment. Danish EU presidency. ENOPE. 11.04.2012, Copenhagen, Denmark.

Sørensen K. Health literacy in Portugal. Public Think Tank. 29.03.2912, National School of Public Health. Lisabon, Portugal.

Sørensen K. Health literacy - a driver for change. Lecture, module on Health Strategy, European Public Health Bachelor Programme. 08.11.2011, Maastricht, the Netherlands.

Sørensen K. Health literacy and empowerment. Master class, School of health technology of Coimbra. 04.11.2011, Coimbra, Portugal.

Sørensen K. Health literacy - the HLS-EU project, Master class, School of Public Health. 03.11.2011, Lisbon, Portugal.

Sørensen K. Reflections on health literacy and media. Department of Social Medicine, Amsterdam Medical Centre, 26.09. 2011, Amsterdam, the Netherlands.

Sørensen K. Workshop on health literacy. Sund By konference, 15.03.2011, Fredericia, Denmark. 
Sørensen K. Health literacy - driving change in flu communication. Health communication and seasonal influenza, European Centre of Disease Control, 21.01.2011, Stockholm, Sweden.

Sørensen K. \& Brand H. Health literacy in Europe. ECDC Pre conference: Communicating in a diverse Europe, 10.11.2011, Amsterdam, the Netherlands.

Sørensen K. Health literacy measurement. WHO Sub Network health literacy meeting, 22.10.2010, Liverpool, United Kingdom.

Sørensen K. The European Health Literacy Survey - pilot result. European Health Forum Gastein, 07.10.2010, Gastein, Austria.

Sørensen K. Advancing health literacy in Europe - a social corporate responsibility? CSR Europe, Joint Venture on Health Literacy, 22.07.2010, Brussels, Belgium.

Sørensen K. The European Health Literacy Survey - from measurement to policy. International Union of Health Promotion and Education Conference, 12.07.2010, Gastein, Austria.

Sørensen K. Health literacy and equity. WHO Healthy City Network - technical conference, 18.06.2010, Sandness, Norway.

Sørensen K. The European Health Literacy Survey. Department of Social Medicine, Amsterdam Medical Centre, 27.05. 2010, Amsterdam, the Netherlands.

Sørensen K. Exploring health literacy. South-Eastern European Network meeting, 14.04.2010, Maastricht, the Netherlands.

Sørensen K. Exploring health literacy. National coordinator's meeting, WHO Healthy City Network, 19.03.2010 Tel Aviv, Israel.

Sørensen K. Exploring health literacy. Nordic Network on Health Promotion, 18.03.2010 Göteborg, Sweden.

Sørensen K. Conceptualizing and measuring critical health literacy in the context of the HLS-EU. European Public Health Association Conference, 26.11.2009, Lodz, Poland.

Sørensen K. Measuring health literacy in Europe: The development of the HLS-EU tool. WHO world conference on health promotion, 25.10.2009 Nairobi, Kenya.

Sørensen K Measuring health literacy in Europe: The development of the HLS-EU tool. Swiss Public Health Conference, 27.09.2009, Zürich, Switzerland.

\section{Health literacy related infographics (films)}

HLS-EU The Movie by Kristine Sorensen, Zjelco Felder and Media\&More, 2012. http://www.youtube.com/watch?v=fzMA9TIPJUk

The Blueprint on Health Literacy by CSR Europe, 2013 by CSR Europe.: http://www.youtube.com/watch?v=QsP03kZIDMg 